U. S. DEPARTMENT OF COMMERCE BUREAU OF STANDARDS

\title{
FILTERS FOR THE REPRODUCTION OF SUNLIGHT AND DAYLIGHT AND THE DETERMINATION OF COLOR TEMPERATURE
}

By RAYMOND DAVIS and K.S. GIBSON 

U. S. DEPARTMENT OF COMMERCE

R. P. LAMONT, Secretary

BUREAU OF STANDARDS

GEORGE K. BURGESS, Director

MISCELLANEOUS PUBLICATION, BUREAU OF STANDARDS, No. 114

\section{FILTERS FOR THE REPRODUCTION OF SUNLIGHT AND DAYLIGHT AND THE DETERMINATION OF COLOR TEMPERATURE}

By

RAYMOND DAVIS

K. S. GIBSON

January 21, 1931

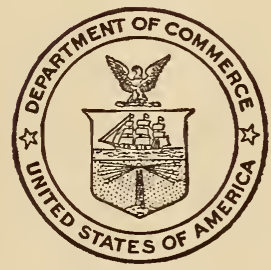

UNITED STATES

GOVERNMENT PRINTING OFFICE

WASHINGTON : 1931

For sale by the Superintendent of Documents, Washington, D. C. - - - Price 45 cents 



\title{
FILTERS FOR THE REPRODUCTION OF SUNLIGHT AND DAYLIGHT AND THE DETERMINATION OF COLOR TEMPERATURE ${ }^{1}$
}

\author{
By Raymond Davis and K. S. Gibson
}

\section{ABSTRACT}

A large number of filters, as listed in the introduction of the paper, have been developed for use in photographic sensitometry, colorimetry, and photometry. They are reproducible from specification and may be prepared in the laboratory. They consist of a 2-compartment cell with three borosilicate crown glass windows, the two compartments being filled, respectively, with solutions A and B, having compositions as follows:

Solution A

Copper sulphate $\left(\mathrm{CuSO}_{4} .5 \mathrm{H}_{2} \mathrm{O}\right) \ldots \ldots$

Mannite $\left(\mathrm{C}_{6} \mathrm{H}_{8}(\mathrm{OH})_{6}\right)_{2}$

Pyridine $\left(\mathrm{C}_{5} \mathrm{H}_{5} \mathrm{~N}\right) \ldots \ldots$

Water (distilled) to make... 1,000

Solution B

Copper sulphate $\left(\mathrm{CuSO}_{4} .5 \mathrm{H}_{2} \mathrm{O}\right)$

Cobalt ammonium sulphate $\left(\mathrm{CoSO}_{4} \cdot\left(\mathrm{NH}_{4}\right)_{2} \mathrm{SO}_{4} \cdot 6 \mathrm{H}_{2} \mathrm{O}\right)_{-} \mathrm{g}_{--}$

Sulphuric acid (specific gravity 1.835) ..................

Water (distilled) to make _.......................... 1, 000

$c_{1}$

$10 . c_{2}^{c_{2}}$

The values of $c, c_{1}$, and $c_{2}$ vary from one filter to another.

The design of the filters has been based upon extensive spectrophotometric measurements of the component solutions and cell, including a study of Beer's law over the ranges of concentrations used, and upon methods of computation giving accurate color matches and relatively good spectral energy matches between the source-and-filter combination and the energy distribution which it was sought to duplicate. Detailed studies have been made of the reliability of the data, the spectrophotometric reproducibility of the chemicals, the permanence of the solutions, their temperature coefficients, and various other factors of importance in the preparation and use of the filters.

The paper contains 33 figures and 26 tables, giving among other things the energy distributions and fundamental spectrophotometric and colorimetric data used in the computations, auxiliary spectrophotometric and colorimetric information obtained during the investigation, and the trilinear coordinates of the various source-and-filter combinations and of the Planckian radiator from $1,600^{\circ}$ to $20,000^{\circ} \mathrm{K}$. computed on the basis of the adopted mean sun as the "neutral" stimulus. The filters are further described in 38 charts, each chart giving the chemical formula, the spectral transmission, and the light transmission of the filter, as well as the spectral energy distribution of the source, that of the source and filter combined, and the energy distribution which serves as the ideal in that particular case.

1 Partial reports of this investigation have been published as follows:

1. Davis and Gibson, Reproducible Liquid Filters for the Production of "White Light" (abstract), J. Opt. Soc. Am. and Rev. Sci. Inst., 14, p. 135; February, 1927.

2. Davis and Gibson, Reproducible Liquid Filters for the Determination of the Color Temperatures of Incandescent Lamps (abstract), Phys. Rev. (2), 29, p. 916; June, 1927.

3. Davis and Gibson, Filters for the Reproduction of Sunlight and the Determination of Color Temperature (abstract), J. Opt. Soc. Am. and Rev. Sci. Inst., 16, p. 332; May, 1928.

4. Gibson and Davis, Methods for Determining the Color of Sunlight and Daylight (abstract), J. Opt. Soc. Am. and Rev. Sci. Inst., 18, p. 442; June, 1929.

5. Davis and Gibson, Artificial Sunlight for Photographic Sensitometry, Trans. Soc. Motion-Picture Engineers, 12, No. 33, pp. 225-236; 1928; Proc., Seventh International Congress of Photography, July, 1928, pp. 161-173.

6. A Filter for Changing the Color Temperature of $2,848^{\circ} \mathrm{K}$. to Average Daylight, B. S. Tech. News Bull., No. 138, pp. 143-144; No. 139, p. 156; 1928.

7. Filters for the Reproduction of Sunlight and the Determination of Color Temperature. (Proposed Working Standards for Sensitometry, Colorimetry, and Photometry.) Standards Yearbook, pp. 188-191; 1928; also Standards Yearbook, pp, 138-141; 1930. 


\section{CONTENTS}

I. Introduction

II Characteristics of white-light filters

1. Previous investigations

2. Desirable features

III. Spectral energy distributions

1. Noon sunlight at Washington $\ldots \ldots \ldots$

(a) Abbot's data

(b) A standard for sensitometry

2. Sunlight outside the earth's atmosphere-a standard of

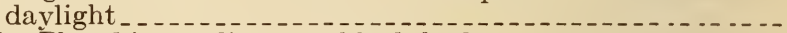

3. The Planckian radiator or black body

(a) An equivalent of incandescent illuminants-color temperature

(b) Energy distributions, $2,000^{\circ}$ to $20,000^{\circ} \mathrm{K}$

(c) Use of high color temperatures........

4. The acetylene flame

IV. Component materials of filters

1. Choice of materials_...........

(a) Aqueous ammonia solution of copper sulphate.--

(b) Aqueous pyridine solution of copper sulphate with mannite - solution A _....................

(c) Aqueods acidified solution of copper sulphatesolution $\mathrm{B}_{1}$

(d) Aqueous acidified solution of cobalt sulphate....

(e) Aqueous acidified solution of cobalt ammonium sulphate-solution $\mathrm{B}_{2 \ldots}$

(f) Mixture of solutions $\mathrm{B}_{1}$ and $\mathrm{B}_{2}-$ solution $\mathrm{B}_{-\ldots-}$

(g) Cell for holding filter solutions $\ldots \ldots \ldots$

(h) Definition of Davis-Gibson filters....

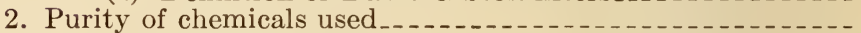

(a) Copper sulphate......

(b) Cobalt ammonium sulphate

(c) Pyridine.

(d) Mannite

(e) Ammonia. .

V. Methods of computation

1. Spectrophotometric terminology

2. Standard spectrophotometric data

3. Beer's law correction for solution $\mathrm{A}$

4. Design of filters of Series $I-2,300^{\circ}-4,000^{\circ} \mathrm{K}$. to mean noon sunlight

(a) To obtain spectral energy match...........

(b) To obtain color match

(c) To compute light transmission of filters

5. Design of filters of Series II $-2,848^{\circ}$ to $3,500^{\circ}-10,000^{\circ} \bar{K}_{\text {- }}^{-}$

6. Design of miscellaneous filters . . _ _.

(a) Acetylene to mean noon sunlight

(b) $2,848^{\circ} \mathrm{K}$. to noon sunlight at summer and winter solstices

(c) $2,848^{\circ} \mathrm{K}$. to Abbot-Priest sunlight

(d) $2,848^{\circ} \mathrm{K}$. to sunlight outside earth's atmospherevariation with color temperature of source.......

(e) $2,450^{\circ}$ to $3,500^{\circ} \mathrm{K}$. and to $6,500^{\circ} \mathrm{K}$. - variation with color temperature of source.......

VI. Use of the filters 1 . In photographic sensitometry

(a) International unit of intensity for sensitometry--

2. In colorimetry

(a) Neutral stimula

(b) Methods for measuring the color of natural sunlight and daylight

(c) Standards for grading daylight glasses and artificial white-light illuminants..............

(d) Calibration of incandescent electric lights in terms of color temperature.................. 
VI. Use of the filters-Continued.

3. In photometry-comparison of intensities of incandescent electric lights of different color temperatures............

4. In astronomy-determining the color temperatures of the stars

VII. Spectrophotometric data.

1. Apparatus and methods

(a) Visual method.........

(b) Auxiliary methods

(c) Miscellaneous

2. Standard filter components

(a) Two-compartment glass cell with distilled water.-

(b) Solution $\mathrm{A}^{\prime}$

(c) Solution $\mathrm{B}_{1}{ }^{\prime}$

(d) Solution $\mathrm{B}_{2}{ }^{\prime}$

(e) Solution $\mathrm{B}^{\prime}$

3. Permanence of solutions

4. Temperature effects.

(a) Solution A .

(b) Solution B

5. Variation of pyridine content in solution $\mathrm{A}$

6. Beer's law

(a) Solution A

(b) Solution B

7. Reliability of the spectrophotometric measurements....

(a) At the $\mathrm{Hg}$ and $\mathrm{He}$ wave lengths

(b) From $350 \mathrm{~m} \mu$ to $720 \mathrm{~m} \mu$

8. Spectrophotometric reproducibility of the chemicals...-

9. Auxiliary data

(a) Aqueous pyridine solution of cobalt sulphate

(b) Aqueous $\alpha$-picoline solution of copper sulphate with

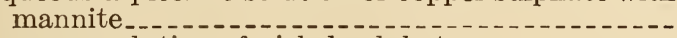

(c) Aqueous solution of nickel sulphate.....

(d) Aqueous solution of pyridine

(e) Aqueous solution or sulphuric acid.

10. Use of solutions and data in spectrophotometric calibration. VIII. Examination and trial of completed filters

1. Spectrophotometric measurements

2. Colorimetric computations _...

(a) Spectrophotometric uncertainty

(b) Deviation from theoretical concentrations

(c) Deviation from theoretical pyridine content

(d) Deviation from standard temperature of $25^{\circ} \mathrm{C}-\ldots$

(e) Change with time.

(f) Change with $\mathrm{C}_{2}$ in Planck's equation

(g) Experimentally determined energy

3. Effect of pyridine content on resulting energy distribution-

4. Preliminary tests of the color of noon sunlight and daylight at Washington.

5. Determination of color temperature of incandescent lights.

6. Test of acetylene-to-mean-sun filter. .

IX. Preparation of Davis-Gibson filters

1. Selection of chemicals

2. Preparation of $\mathrm{A}$ and $\mathrm{B}$ solutions.

3. Preparation and filling of cells

X. Charts describing Davis-Gibson filters

Page

78

79

80

80

80

80

81

81

82

82

83

85

86

86

88

88

89

92

93

93

97

98

98

102

102

110

110

110

112

113

113

114

115

116

119

122

123

123

124

125

125

126

127

129

131

132

134

134

134

135

136

163

\section{INTRODUCTION}

Both in photographic sensitometry and in colorimetry the need for a practical and reproducible working standard of "white light" is well recognized, although there is as yet no universal agreement regarding a precise definition of white light itself. It is generally conceded, however, that the spectral energy distribution of such white light must approximate that of daylight, noon sunlight, or a Planc- 
kian radiator or "black body" at some color temperature between $4,000^{\circ}$ and $8,000^{\circ} \mathrm{K}$. (For the sake of brevity in the present paper, the authors have used the expression "white light" where it is desired not to be specific, but to refer to radiant energy having a spectral distribution approximating these.)

In the meantime the need is being met by the use of arbitrary working standards. In the description of a color in terms of dominant wave length, purity, and brightness, or in terms of the three excitations, whether such description is by way of computation from spectral distribution or by direct observation, a standard "white," often termed a "neutral" stimulus, is necessary. For such computations, Ives (1) ${ }^{2}$ has proposed and used the spectral energy distribution of a Planckian radiator at $5,000^{\circ} \mathrm{K}$. Likewise, Priest $(2,3)$ has devised, both for computation and direct experiment, an artificial sunlight which has been extensively used as a "neutral" stimulus in various investigations at the National Bureau of Standards. Further information regarding the need and uses of standard white light may be found in a report (4) of the Committee on Colorimetry for 1920-21, Optical Society of America, and also in a paper by Guild (5). It may be emphasized that, while the establishment and general adoption of a standard "neutral" stimulus satisfactory in all respects to all concerned is of fundamental importance, valuable contributions have been and are being made to the science of colorimetry by the use of standards such as those noted above, which are not in universal use. It may be further noted that, while any reasonable energy distribution may be readily used in colorimetric computations as a standard white, the accurate reproduction of such distribution in the laboratory may not be possible.

In photographic sensitometry the most important factor in specifying the characteristics of photographic negative materials is that referred to as speed. This has been emphasized in a report $(6,7)$ of the Committee on the Unit of Photographic Intensity, Optical Society of America. It was there pointed out that relative speeds measured by incandescent light in the laboratory were radically different from the relative speeds obtained under the sunlight illumination to which the great majority of photographic negative materials are exposed. This is a result, of course, of the widely varying spectral sensitivities of the different emulsions. The ordinary emulsions are sensitive only to the blue and violet (besides, of course, the ultra-violet), the orthochromatic to the violet, blue, and yellow, and the panchromatic in varying degrees to the whole visible spectrum.

In 1925 the Sixth International Congress of Photography tentatively adopted $(6,8)$ two standards of energy distribution for use in sensitometry; one a color temperature of $2,360^{\circ} \mathrm{K}$. (nominally the acetylene flame), and the other a color temperature of $5,000^{\circ} \mathrm{K}$. (representing sunlight) to be obtained by means of a specified light filter and a $2,360^{\circ} \mathrm{K}$. source as recommended by the American committee. The recommendations ${ }^{3}$ were as follows $(6,8)$ :

${ }^{2}$ Numbers in parentheses, followed occasionally by page references, refer to the Bibliography at the end of the paper.

3 The action taken by the Seventh International Congress of Photography in 1928 is considered later in Section VI, 1 . 
1. It is recommended to use, for sensitometric work, a light source of which the radiation is identical with that of a black body at $2,360^{\circ}$ (absolute).

The intensity of this source shall be expressed in candles. This intensity shall be measured visually by ordinary photometric procedure in comparison with the usual photometric standards.

2 . In case it is considered necessary to use radiation representing approximately the radiation of a black body at $5,000^{\circ}$ absolute (average daylight day) there shall be placed before the light source provided in the preceding paragraph, a colored filter suitably chosen.

3. It is provisionally recommended to use for this purpose a filter composed of two distinct liquids, each of a thickness of $10.0 \mathrm{~mm}$. One of these liquids shall be an aqueous solution of which 100 cubic centimeters shall contain 3.00 grams of pure crystallized copper sulphate $\mathrm{CuSO}_{4} .5 \mathrm{H}_{2} \mathrm{O}$ and 5 cubic centimeters of a solution of sulphuric acid containing per liter 50 grams of pure sulphuric acid reading $66^{\circ}$ Baumé. The other liquid shall consist of an aqueous solution of copper ammoniacal sulphate containing three times the quantity of ammonia necessary to give the compound $\mathrm{Cu}\left(\mathrm{NH}_{3}\right) \mathrm{SO}_{4} ; 100$ cubic centimeters of this solution should contain a quantity of copper corresponding to 0.50 gram of pure crystallized copper sulphate $\mathrm{CuSO}_{4} .5 \mathrm{H}_{2} \mathrm{O}$; this solution should not be prepared before use for less than a day nor more than a month.

The cell shall be made of three sheets of white polished glass, the thickness of each sheet being not less than $2 \mathrm{~mm}$ nor greater than $4 \mathrm{~mm}$. The cell used should be closed.

This compensating filter was hurriedly devised (at the Research Laboratory of the Eastman Kodak Co.), as the time was very limited and the American committee was unanimous in its opinion that daylight or sunlight quality should be used in determining the speeds of photographic emulsions. While this filter did not give the $5,000^{\circ} \mathrm{K}$. energy distribution with the desired accuracy, it was distinctly better for the purpose than the $2,360^{\circ} \mathrm{K}$. source alone. It was suitable for temporary use, but was not acceptable as a permanent International Standard.

The problem of devising suitable filters for converting the color and spectral energy distribution of incandescent light sources to those of sunlight, $5,000^{\circ} \mathrm{K}$., or other possible white light, was of interest to the authors not only as members of the American committee noted above, but also in connection with the work of those sections of the National Bureau of Standards devoted to photographic and colorimetric research. The investigation has developed greatly since its inception, and the scope of the material herein presented may be outlined as follows:

1. A series of filters has been developed by which the spectral energy distribution of a Planckian radiator at any color temperature from $2,300^{\circ}$ to $4,000^{\circ} \mathrm{K}$., inclusive, may be converted into a close approximation of the spectral energy distribution of mean noon sunlight at Washington. The data cover the range from $350 \mathrm{~m} \mu$ to $720 \mathrm{~m} \mu$. Light transmissions have been computed for all the filters.

2. By designing these filters so that they all give an accurate color match with the adopted mean sunlight, in addition to a close energy match, they may be used to calibrate the intensity and color temperature of incandescent lamps at any color temperature above $2,300^{\circ} \mathrm{K}$., provided a source is available calibrated for intensity and color temperature at some one color temperature within this range. The comparison of intensities of incandescent lamps at different color temperatures may thus be made under conditions of exact color match.

3. A second series of filters has been developed for converting the color of a Planckian radiator at $2,848^{\circ} \mathrm{K}$. to that of any Planckian radiator between $3,500^{\circ}$ and $10,000^{\circ} \mathrm{K}$., inclusive, keeping the energy distribution as closely matched as possible. 
4. Seven additional filters, not in the above series,"are also given, viz: (a) A filter for converting $2,848^{\circ} \mathrm{K}$. to the color of the sun outside the earth's atmosphere, which satisfactorily represents the color of overcast sky, this filter thus affording a reproducible daylight standard. By varying the color temperature of the light source from $2,300^{\circ}$ to $3,000^{\circ} \mathrm{K}$. the filter will closely match the colors given by daylight and noon sunlight; (b) a filter for converting $2,848^{\circ} \mathrm{K}$. to Abbot-Priest sunlight; (c) a filter for converting acetylene to mean noon sunlight at Washington; $(d)$ and $(e)$ two filters, one for converting $2,848^{\circ} \mathrm{K}$. to noon sunlight at the summer solstice at Washington and the other for converting $2,848^{\circ} \mathrm{K}$. to noon sunlight at the winter solstice at Washington; $(f)$ and $(g)$ two filters designed to cover a wide range of black-body color temperatures by varying the color temperature of the light source between the limits of $2,000^{\circ}$ and $3,100^{\circ} \mathrm{K}$. With this variation one of the filters covers the blackbody scale from $2,650^{\circ}$ to $5,000^{\circ} \mathrm{K}$., and the other from $4,000^{\circ}$ to $19,000^{\circ} \mathrm{K}$.

5. Spectral transmissive data are given on the standard component solutions which should be of value in checking and calibrating spectrophotometric apparatus. Various other detailed information is given concerning these solutions which is of permanent value independent of their use in the filters.

6. Tables of energy and visibility data are presented which are convenient for general reference, viz: (a) The relative spectral energy of various phases of sunlight, from Abbot's data; $(b)$ the relative spectral energy of a Planckian radiator, from $350 \mathrm{~m} \mu$ to $720 \mathrm{~m} \mu$, at various intervals from $2,000^{\circ}$ to $20,000^{\circ} \mathrm{K}$., the values being taken or computed from the tables and curves (9) of B. S. Miscellaneous Publication, No. 56; $(c)$ the internationally adopted (10) visibility data as recommended by Gibson and Tyndall $(11,12)$.

7. Tables are presented from which the trilinear coordinates $(r, g, b)$ may be obtained for a Planckian radiator at any temperature from $1,600^{\circ}$ to $20,000^{\circ} \mathrm{K}$., on the basis of the adopted mean sunlight as standard "white." The excitations and the method used in these computations are given so that the $r, g$, and $b$ coordinates may be computed for any desired energy distribution.

The division of work between the photographic and colorimetry sections of the bureau has been, in general, as follows: The former has been responsible for the selection of the materials best suited for the purpose, for devising methods for the determination of the correct proportions of the ingredients-(filter design), and for the very extensive computations necessary to the final solution of the problem; the latter has been responsible for the energy distributions, and for the fundamental spectrophotometric data on the solutions, including the miscellaneous studies of Beer's law, temperature effect, permanence, etc.

The authors take pleasure in making the following acknowledgments:

To Hugh K. Clark for general assistance throughout the investigation, this consisting of extensive computations and reduction of data, preparation of graphs for publication, and preparation of chemicals and solutions; to $\mathrm{E}$. Wichers for advice regarding copper and cobalt 
salts; to A. Isaacs for the chemical analysis of such salts and solutions; to Burt $\mathrm{H}$. Carroll for advice, analysis, and titrations used in the study of pyridine and picoline; to Mabel E. Brown for assistance in spectrophotometric measurements and computations; to Irwin G. Priest for his interest and encouragement in the development of the filters; and to others, as noted at various places in the paper.

\section{CHARACTERISTICS OF WHITE-LIGHT FILTERS}

\section{PREVIOUS INVESTIGATIONS}

The problem of absorbing the excess energy of the longer wave lengths in conmon incandescent illuminants has been a subject of investigation for many years. In general, such research and development have had one of two objects in view.

In one case the problem has been the commercial production and utilization of white light. "Artificial daylight" is a term used to advertise a wide variety of illuminants varying in the color of their light at normal operation from yellower than noon sunlight to the blue of north skylight and produced by bluish "daylight" glass in one form or another used as a filter for the yellow light of the incandescent source. Those interested in the development of this kind of glass should refer to papers by Ires (13), Luckiesh and Cady (14), Brady (15), and Gage (16) and to the bibliographies given in the first two of these papers. Combinations of glass and dyed gelatin were tried in some cases, but the daylight glasses finally evolved have proved satisfactory for general illumination purposes without the use of any additional material. A recent survey of the present status of artificial white-light illumination may be found in a paper by Macbeth (17). The filters described in the present paper were not designed for general illumination but for scientific purposes. They will, however, serve in an excellent manner as standards for the testing and calibration of davlight glass and artificial white-light illumination.

In the other case the problem has been the development of permanent and reproducible filters for laboratory use in photographic sensitometry, colorimetry, or photometry. Lacking more suitable filters, daylight glass has often been used for scientific purposes. It is not sufficiently reproducible, however, for many kinds of work and the spectral distribution which it gives often deviates more widely from the ideal than is desirable. Various other attempts have been made to devise filters which could be prepared in the laboratory from specification, and which would be satisfactory as regards permanence, convenience, and spectral distribution. The following brief résumé will illustrate what has been attempted and what is available along this line.

One of the earliest attempts, apparently, is that of Mees and Sheppard $(18$, p. $292 ; 19$, p. 314) who devised filters for converting the energy distribution of the acetylene flame to that of daylight. Their method for designing the filters was to take photographs on panchromatic plates in a Tallent spectroscope, altering the composition of the filter placed in front of the acetylene burner until the 
resulting energy gave, as nearly as possible, the same curve as daylight. Their final filter was $1 \mathrm{~cm}$ each of the following two solutions:
A. Gentian violet. g_- 0.002
Acid green
Mandarin orange
Rose bengal
Water to make....... 100
B. Copper acetate
Water to make........ 100

This filter was apparently unsatisfactory as regards stability and the accuracy with which it reproduced the ideal spectral distribution. A later filter (20) is noted in which only dyes are used and which was considered permanent. The composition of the filter is not given, however, and the practical difficulties of preparing the filter were said to be considerable.

The present Wratten filters (21), made of dyed gelatin-No. 78 "Tungsten to daylight (visual)," No. 78AA "Tungsten (Mazda C) to daylight," and No. 79, "Acetylene to daylight" - are doubtless the result of this earlier work. They are classed as "stable" or "moderately stable." Illustrations of the energy distributions obtainable with these filters are given below. (Fig. 1.)

A dyed gelatin filter for converting $2,200^{\circ}$ to $5,000^{\circ} \mathrm{K}$. has been described by Naumann (22). In its final form, superseding previously published formulas, the filter is composed as follows:

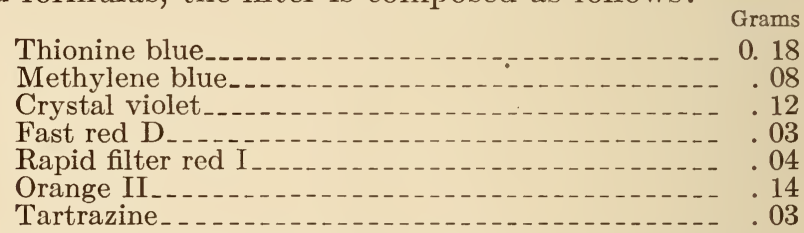

These dyes are dissolved separately and the solutions mixed and prepared for coating by addition of gelatin. The formula is designed to cover $1 \mathrm{~m}^{2}$ of filter surface. Small scale density curves of this and the author's previous filters are given, but, otherwise, no quantitative data are supplied from which one could derive the spectral energy distribution or color of this filter. It is said to be somewhat bluer than daylight in spite of the fact that it was intended to duplicate $5,000^{\circ} \mathrm{K}$. Questions of reproducibilityand permanence are not adequately considered.

A different type of filter, developed by Pfund, is described by Sinden (23) as a liquid-cell having two distinct compartments, one of which contained an aqueous solution of ammoniacal copper sulphate and the other an aqueous solution of the sulphates of copper and cobalt. The filter was used with a lamp operated at $3,000^{\circ} \mathrm{K}$., and an actual comparison showed that this combination gave no appreciable color difference from noon sunlight at Baltimore, in April. Its energy distribution compared with that of the O. S. A. average noon sunlight is briefly illustrated. No details regarding proportions of the ingredients were given. It would appear that this filter was designed by trial and error procedure and the exact proportions have apparently never been published.

More recently Guild (24) has described two tentative filters devised by his colleague Young, using materials similar to those in Pfund's filter. One of these is for converting $3,260^{\circ}$ to $3,000^{\circ} \mathrm{K}$. and the 
other for converting $3,000^{\circ}$ to $5,000^{\circ} \mathrm{K}$. for use as a standard white for colorimetry. Their compositions are given as follows:

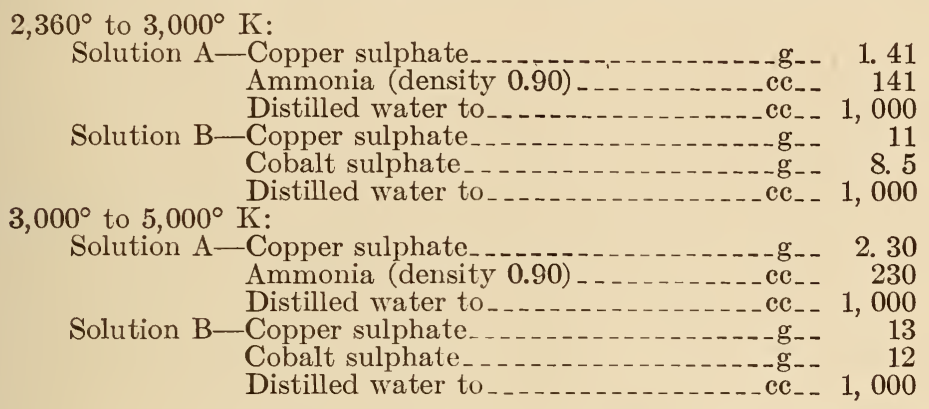

Solutions A and B are contained in separate compartments of a double cell, of which the walls are of optical glass having very high and as nearly as possible nonselective transmission. The thickness of each solution is $10.00 \mathrm{~mm}$. It is emphasized that the figures given are provisional and that some modification must be looked for in a subsequent publication, when "full particulars of the actual energy distribution, etc., will be given." Such publication has apparently not yet appeared. ${ }^{4}$ Guild's filter is, however, now being sold by Hilger (25) under the name of "Standard artificial daylight."

In 1918 Priest (2) proposed the use of a rotatory dispersion filter for obtaining artificial noon sunlight from the gas-filled tungsten lamp operated at 15.6 lumens per watt. He shortly after this changed the specification of the source to a lamp at a color temperature $2,848^{\circ} \mathrm{K}$., this being a more precise form of specification having the same intent. The resulting energy distribution has been designated as "AbbotPriest sunlight." Since this proposal the filter has been constructed and in service at the National Bureau of Standards for some time. The filter consists (3) "of a crystalline quartz plate between "crossed nicols,' the plate being $0.500 \mathrm{~mm}$ thick and placed so that the path of light is parallel to the optic axis. These parts are built in a cell which is inserted as a unit near the eye in the optical train of the colorimeter. The effect is that of a blue filter having a spectral transmission such that the spectral distribution of energy delivered to the observer's eye approximates very closely to average natural noon sun at Washington." The desired reproduction was considered more precise than had previously been obtained by blue glass, dyed gelatin filters, or solutions of selective absorbents.

Artificial white-light filters available commercially include:

1. The Wratten No. 78, No. 78AA, and No. 79, as noted above, manufactured by the Eastman Kodak Co. These filters are composed of dyed gelatin cemented between optical glass flats.

2. Guild's filter as sold by Hilger.

3. Daylight glass, particularly the Luckiesh "Trutint" and the Corning "Daylite" glass. The thickness of glass necessary to obtain the nearest approximation to the desired energy distribution

\footnotetext{
${ }^{4}$ A partial revision of the specification has, however, been made and is given in the Appendix to a paper by W. D. Wright, A Redetermination of the Trichromatic Coefficients of the Spectral Colors, Trans. Opt. Soc., 30, pp. 141-164; 1928-29. The auxiliary filter for rating the gas-filled lamp is unchanged, but the color temperature obtained when it is used with a $2,360^{\circ} \mathrm{K}$. source is now "believed to be very close to $2,900^{\circ} \mathrm{K}$." The "white light" filter has been changed in that the copper and cobalt sulphates in solution $\mathrm{B}$ are now given as $15 \mathrm{~g}$ each instead of the 13 and $12 \mathrm{~g}$ above given. The color temperature obtained with this filter (with source calibrated by means of the auxiliary filter) is now considered to be "approxi mately $4,800^{\circ} \mathrm{K}$."
} 
depends, of course, upon the color temperature of the source to be used with the glass as well as upon the spectral transmission characteristics of the glass itself. Corning "Daylite" glass has been used by Davis in his work on photographic sensitometry (26). The particular sample used converted the color of a gas-filled lamp operated at $2,810^{\circ} \mathrm{K}$. to that of noon sunlight.

The spectral distributions which may be obtained by some of the foregoing filters are shown in the accompanying figures. Figure 1 shows the computed energy distributions of the three Wratten filters, based on the published spectral transmission data (21) for them. With Wratten No. 78 the energy for $2,360^{\circ} \mathrm{K}$. was used, with No. $78 \mathrm{AA}$ that for $2,900^{\circ} \mathrm{K}$., and with No. 79 the energy data of Coblentz (27) for acetylene. Mean sunlight ${ }^{5}$ daylight, and $5,000^{\circ} \mathrm{K}$. are also included for comparison.

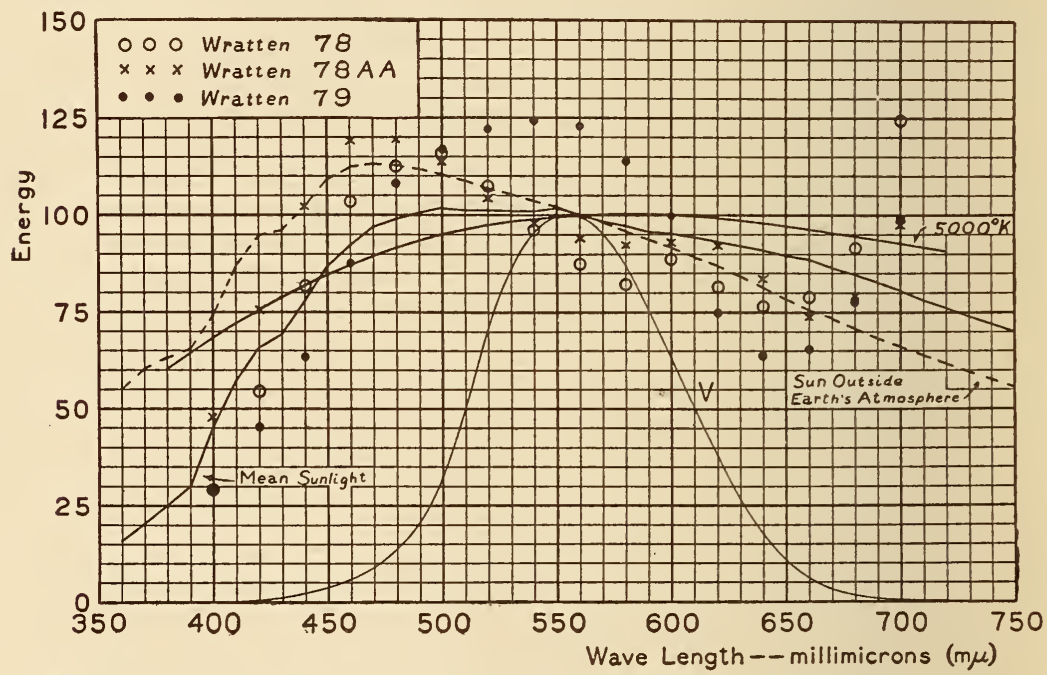

FIGURE 1.-Relative energy distributions obtained with Wratten filters as indicated, compared to $5,000^{\circ} K$., mean sunlight, and sun outside earth's atmosphere (which approximates average daylight)

With No. 78 , the energy for $2,360^{\circ} \mathrm{K}$. was used; with No. $78 \mathrm{AA}$, that for $2,900^{\circ} \mathrm{K}$; and with No. 79 , the energy distribution of acetylene was used.

In Figure 2 is shown the relative energy distribution obtained with the filter tentatively adopted by the Sixth International Congress of Photography in 1925 . The data were computed using a $2,360^{\circ} \mathrm{K}$. source (black-body distribution) and a spectral transmission obtained by the writers on a solution made up in accordance with the formula already given using 36 cc of ammonia. Also on the graph are plotted $5,000^{\circ} \mathrm{K}$. (the ideal in this case) and mean sunlight for comparison.

Figure 3 illustrates Abbot-Priest sunlight as calculated (by Priest) for the rotatory dispersion filter. For comparison mean sunlight and $5,000^{\circ} \mathrm{K}$. energy curves are included.

In Figure 4 are shown the energy distributions obtained with two samples of Corning "Daylite" glass from different melts. The thick-

5 The expression "mean sunlight" (or "mean sun") refers specifically in all cases to a certain energy distribution, or its resulting color, as defined in Sec. III, 1. 
nesses of the glass and the color temperatures of the source are noted. The spectral transmission measurements were made at the bureau.

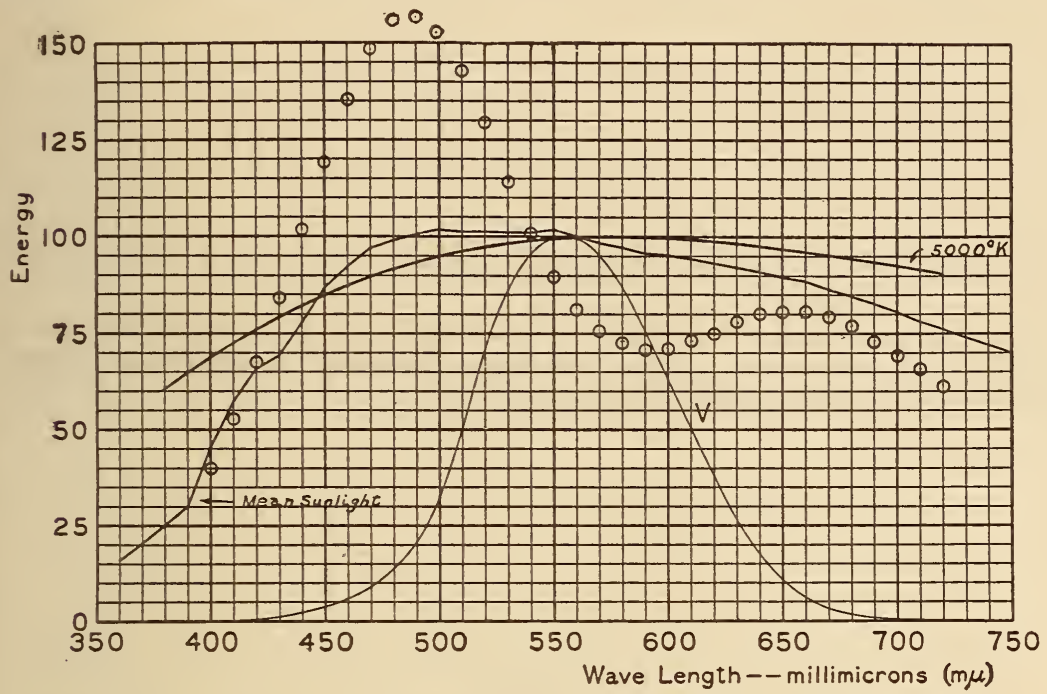

FIGURE 2.-Relative energy distribution obtained with 2,360 $\mathrm{K}$. source and filter tentatively proposed by the Sixth International Congress of Photography (shown by circles) compared with mean sunlight and $5,000^{\circ} \mathrm{K}$.

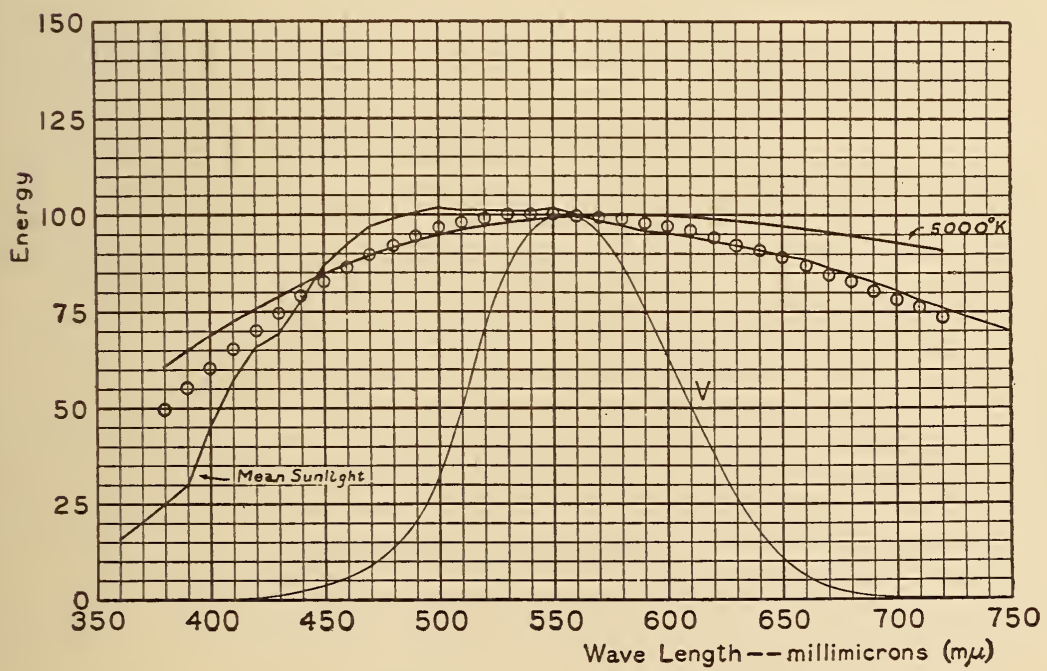

Figure 3.-Relative energy distribution of Abbot-Priest sunlight (shown by circles) compared with mean sunlight and 5,000 $\mathrm{K}$.

For comparison the curves for mean sunlight and $5,325^{\circ} \mathrm{K}$. are also given. 


\section{DESIRABLE FEATURES}

In designing filters for scientific and technical purposes, such as the production of standards of light quality, the following properties would be desirable: (1) Accurate reproducibility from specification, (2) spectral transmissions which are unaffected by time and temperature, (3) spectral transmissions such that the energy distribution obtained is $(a)$ exactly that sought and $(b)$ an exact color match therewith regardless of whether or not $(a)$ is fully satisfied, (4) the highest transmission of light consistent with (3), and (5) other physical properties (size, shape, durability, etc.) which facilitate use of the filters.

It is not to be expected that filters can be constructed which will embody all these properties. No known absorbing materials exist, for example, by means of which it would be possible to get $(3(a))$ a

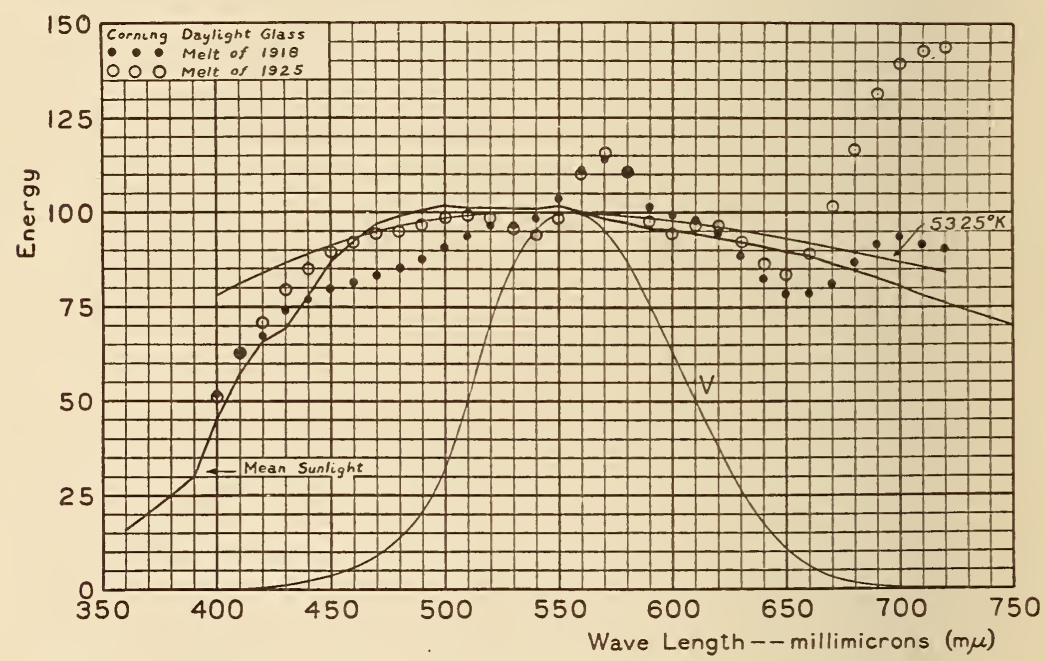

FIGURE 4.-Relative energy distribution obtained with Corning daylight glass as indicated compared with mean sunlight and $5,325^{\circ} \mathrm{K}$.

The thicknesses of glass and color temperatures of source $\pi$ ere: Melt of 1918, $3.59 \mathrm{mim}$ and $2,900^{\circ} \mathrm{K}$; ; melt of $1925,4.75 \mathrm{~mm}$ and $2,810^{\circ} \mathrm{K}$.

perfect match in energy distribution. Careful consideration must be paid to the special purposes of a given filter before the sort of compromise which is most advantageous can be determined. A compromise which would ordinarily be advantageous is to adjust the unaroidable deviations in energy distribution so as to obtain $(3(b))$ an accurate color match and, at the same time, (4) a reasonably high transmission of light. Likewise, the lack of an absorbing medium, strictly permanent and completely independent of temperature, is not practically important if a reasonably permanent medium is available having known temperature coefficients of spectral transmission, because such variations in spectral transmission as may occur can be taken into account. It should be obvious that the minimum requirement (in the past often unfulfilled) in this respect is that the spectral transmission of the filter be accurately known, including the effects of age and temperature. 
From the standpoint of convenience and permanence probably nothing is superior to the various daylight glasses. However, the resulting energy distributions depart, in general, to an undesirable extent from the ideal sought, and, as already illustrated in Figure 4, glass from different formulas or different melts from the same formula vary considerably in this respect. Even the best samples show excess transmission of energy in the yellow-green and usually also in the red. There seem to be no data available regarding changes in transmission with temperature, although cobalt blue glasses do not have very large temperature coefficients over most of the visible spectrum. As ordinarily used with incandescent light, the transmission is reasonably high (10 to 20 per cent). While satisfactory in many respects then, the principal objection to daylight glass is that it can not be accurately reproduced from specification. This outstanding difficulty, together with its spectral irregularities in the yellow-green and red, would seem sufficient to prevent the general adoption of any of the known daylight glasses as working standard filters for the production of white light.

Dye solutions and dyed gelatin films likewise can not be considered reproducible from specification, the dyes themselves being, in general, not accurately reproducible in their spectral characteristics. Furthermore, the absorbancy of dyes (coloring strength) is, in general, so great that it is difficult to make weighings with the desired precision. When spectrophotometric data have been given to an extent sufficient for reliable computation, the resulting energy distributions have been hardly as good as those obtained with daylight glass. A certain stability is claimed for the Wratten filters, but the effects of temperature variation are not given. The use of dyes can not, in general, be recommended, inasmuch as in solution they are not as satisfactory as solutions of inorganic salts (see below) and in dyed gelatin films are not as satisfactory as daylight glass.

The quartz-nicol rotatory dispersion filter described in the previous section is reproducible from specification (although the spectral selectivity of the nicol prisms has been ignored in the computation) and its spectral transmission is accurately known (subject to the same limitation). Its reproduction of sunlight is very satisfactory from a colorimetric standpoint, but its relatively high transmission in the violet and ultra-violet renders it less suitable for photographic purposes. Its light transmission is very low (about $1 \frac{1}{2}$ per cent), and the small dimensions of nicol prisms limit its usefulness practically to the eyepiece of optical instruments. Its temperature coefficient is not given.

Solutions may not at first be considered very convenient to use, but, on the other hand, liquid filters are more readily prepared in the laboratory than any other type. Once prepared and inclosed in a suitable glass cell, they are not inconvenient to handle. The extent to which the desired energy distributions are attained with our liquid filters is brought out in the present paper, together with data regarding reproducibility, permanence, change with temperature, etc. The light transmissions compare very favorably with those of other filters.

It is apparent from the brief discussion given in this and the previous sections, considering the variety of materials and methods which have been used and the degrees of approximation to the desired energy distributions which it has been necessary to accept, that the design 
of satisfactory white-light filters is not a simple undertaking. The reason is not hard to find. No single absorbing material has been found which has the desired spectral characteristics and the number of those which even crudely approximate the desired selectivity is apparently limited.

In general, the first approximation has been secured by the use of some blue coloring material; and additional materials have then been added, to the extent considered necessary, to correct for spectral deficiencies of the principal material. Considering the type of change that occurs in the spectral transmission as the concentration or thickness is varied (see Sec. V, 1), it is obvious that the difficulty has been not merely in finding suitable materials but in adjusting the concentrations of these materials so as to secure the most suitable transmission and resulting energy match.

In the present investigation the problem has been not only that of selecting materials and adjusting them so as to secure the best spectral energy match, but also that of securing exact color matches. This has been done, furthermore, not merely with one filter but with a large number of them, as already outlined in Section I. It is hoped that this work will satisfy the demand felt in many lines of research for reproducible white-light filters which have satisfactory spectral characteristics and which may be readily prepared and conveniently used in the laboratory.

\section{SPECTRAL ENERGY DISTRIBUTIONS}

Before describing the materials and methods of computation which have been used in the development of the present filters, it is necessary to define the various energy distributions which enter into these computations. These include sunlight and daylight energies, various black-body distributions, and that of the acetylene flame.

\section{NOON SUNLIGHT AT WASHINGTON}

Sunlight distribution is of importance to photographic sensitometry, not because it may approximately represent a colorimetric or subjective white, but because it represents, perhaps better than any other single energy distribution, the average conditions ${ }^{6}$ under which the great majority of photographic negative materials are exposed.

\section{(a) ABBOT'S DATA}

Extensive data are available on the spectral energy distribution of noon sunlight at Washington. Such data representative of average atmospheric conditions at the two extremes, the summer and winter solstices, were furnished the National Bureau of Standards by Doctor Abbot, in a letter dated November 7, 1917. These data have served as a basis in the development of Abbot-Priest sunlight as already described. The two sets of data-average noon sunlight at Washington on June 21 and on December 21-are given in Table 1 and illus-

${ }^{6}$ Varying from the incandescent sources often used in indoor motion-picture photography through sunlight to daylight or blue sky, 
trated in Figure 5. The difference between the two sets is of the same order of magnitude as the variation at noon due to changes in atmospheric transmission at a given time of year, and the data do not, of course, at all represent early morning and late afternoon sunlight, which is relatively yellow.

An arithmetical mean of these two sets of noon sunlight energy data, given in Table 1 and illustrated in Figure 5 and elsewhere, was

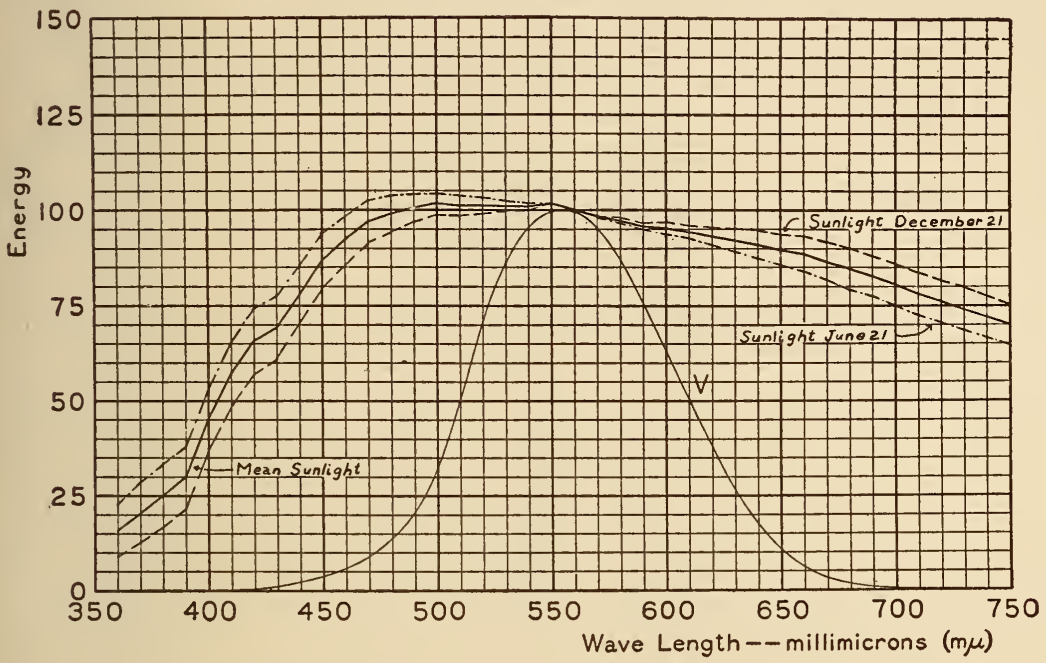

FIGURE 5.-Relative energy distribution of noon sunlight at Washington as given by Abbot's data of 1917 (Table 1 of the present paper)

chosen by the writers as the ideal energy distribution, the duplication of which has been attempted in the first series of filters described herein. It is hereinafter often referred to simply as "mean sun" or "mean sunlight"; and whenever these expressions are used in this paper this particular energy distribution (or color) is meant. The average noon sunlight given in the report $(4, \mathrm{p} .563)$ of the Colorimetry Committee of the Optical Society of America is essentially the same as herein adopted, except below $420 \mathrm{~m} \mu$, where an error has apparently entered in the average data used in that report. The data as used by the writers extend from $360 \mathrm{~m} \mu$ to $720 \mathrm{~m} \mu$.

$$
13416^{\circ}-31-2
$$


Table 1.-Sunlight energy distribution

\begin{tabular}{|c|c|c|c|c|c|c|}
\hline \multirow{3}{*}{ Wave length in millimicrons } & \multicolumn{6}{|c|}{ Relative energy distribution of sunlight } \\
\hline & \multirow{2}{*}{$\begin{array}{l}\text { Outside } \\
\text { earth's at- } \\
\text { mosphere }\end{array}$} & \multicolumn{2}{|c|}{$\begin{array}{l}\text { At Washington, D. C., } \\
\text { at noon, average at- } \\
\text { mospheric trans- } \\
\text { mission }\end{array}$} & \multicolumn{2}{|c|}{ Mean sun² } & \multirow{2}{*}{$\begin{array}{l}\text { Sun }{ }^{2} \text { outside } \\
\text { atmosphere } \\
\text { reduced to } \\
100.00 \text { at } \\
560 \mathrm{~m} \mu\end{array}$} \\
\hline & & June $21^{1}$ & Dec. $21^{1}$ & $\begin{array}{l}\text { Arithmeti- } \\
\text { cal mean of } \\
\text { data for } \\
\text { June } 21 \text { and } \\
\text { Dec. } 21\end{array}$ & $\begin{array}{l}\text { Reduced } \\
\text { to } 100.00 \text { at } \\
560 \mathrm{~m} \mu\end{array}$ & \\
\hline $\begin{array}{l}360 \ldots \\
370 \\
380 \\
390 \\
390\end{array}$ & $\begin{array}{l}59.1 \\
64.5 \\
67.6 \\
69.7\end{array}$ & $\begin{array}{l}24.0 \\
30.0 \\
35.0 \\
40.4\end{array}$ & $\begin{array}{r}9.4 \\
12.8 \\
17.4 \\
22.5\end{array}$ & $\begin{array}{l}16.70 \\
21.40 \\
26.20 \\
31.45\end{array}$ & $\begin{array}{l}15.97 \\
20.47 \\
25.06 \\
30.08\end{array}$ & $\begin{array}{l}55.34 \\
60.39 \\
63.30 \\
65.26\end{array}$ \\
\hline $\begin{array}{l}400 \ldots- \\
410-\cdots \\
420 \\
430 \ldots- \\
440 \ldots\end{array}$ & $\begin{array}{r}79.1 \\
93.0 \\
101.5 \\
102.8 \\
108.9\end{array}$ & $\begin{array}{l}56.0 \\
69.3 \\
78.4 \\
81.5 \\
89.7\end{array}$ & $\begin{array}{l}38.5 \\
50.6 \\
59.3 \\
63.2 \\
72.9\end{array}$ & $\begin{array}{l}47.25 \\
59.95 \\
68.85 \\
72.35 \\
81.30\end{array}$ & $\begin{array}{l}45.19 \\
57.34 \\
65.85 \\
69.20 \\
77.76\end{array}$ & $\begin{array}{r}74.06 \\
87.08 \\
95.04 \\
96.25 \\
101.97\end{array}$ \\
\hline 450 & $\begin{array}{l}117.0 \\
120.0 \\
121.2 \\
120.6 \\
119.4\end{array}$ & $\begin{array}{r}99.1 \\
103.9 \\
107.7 \\
109.2 \\
109.8\end{array}$ & $\begin{array}{r}82.5 \\
89.0 \\
95.0 \\
97.9 \\
100.5\end{array}$ & $\begin{array}{r}90.80 \\
96.45 \\
101.35 \\
103.55 \\
105.15\end{array}$ & $\begin{array}{r}86.85 \\
92.25 \\
96.94 \\
99.04 \\
100.57\end{array}$ & $\begin{array}{l}109.55 \\
112.36 \\
113.48 \\
112.92 \\
111.80\end{array}$ \\
\hline $\begin{array}{l}500 \ldots \ldots \\
510 \ldots \ldots \\
520 \ldots \ldots \\
530 \ldots \ldots \\
540 \ldots \ldots\end{array}$ & $\begin{array}{l}117.7 \\
116.0 \\
114.3 \\
112.6 \\
110.8\end{array}$ & $\begin{array}{l}110.2 \\
109.2 \\
108.7 \\
107.8 \\
107.3\end{array}$ & $\begin{array}{l}102.6 \\
102.3 \\
102.9 \\
103.5 \\
103.7\end{array}$ & $\begin{array}{l}106.40 \\
105.75 \\
105.80 \\
105.65 \\
105.50\end{array}$ & $\begin{array}{l}101.77 \\
101.15 \\
101.20 \\
101.05 \\
100.91\end{array}$ & $\begin{array}{l}110.21 \\
108.61 \\
107.02 \\
105.43 \\
103.75\end{array}$ \\
\hline $\begin{array}{l}550 \ldots \\
560 \ldots \\
570 \ldots \\
580 \ldots \\
590 \ldots\end{array}$ & $\begin{array}{l}109.1 \\
106.8 \\
104.6 \\
102.3 \\
100.0\end{array}$ & $\begin{array}{l}107.3 \\
105.4 \\
103.4 \\
101.8 \\
100.0\end{array}$ & $\begin{array}{l}105.4 \\
103.7 \\
102.3 \\
101.4 \\
100.0\end{array}$ & $\begin{array}{l}106.35 \\
104.55 \\
102.85 \\
101.60 \\
100.00\end{array}$ & $\begin{array}{r}101.72 \\
100.00 \\
98.37 \\
97.18 \\
95.65\end{array}$ & $\begin{array}{r}102.15 \\
100.00 \\
97.94 \\
95.79 \\
93.63\end{array}$ \\
\hline $\begin{array}{l}600 \\
610 \\
630 \\
640\end{array}$ & $\begin{array}{l}97.7 \\
95.2 \\
92.4 \\
89.7 \\
86.8\end{array}$ & $\begin{array}{l}98.8 \\
97.5 \\
95.7 \\
94.0 \\
92.1\end{array}$ & $\begin{array}{r}100.2 \\
99.6 \\
99.1 \\
98.7 \\
98.2\end{array}$ & $\begin{array}{l}99.50 \\
98.55 \\
97.40 \\
96.35 \\
95.15\end{array}$ & $\begin{array}{l}95.17 \\
94.26 \\
93.16 \\
92.16 \\
91.01\end{array}$ & $\begin{array}{l}91.48 \\
89.14 \\
86.52 \\
83.99 \\
81.27\end{array}$ \\
\hline $\begin{array}{l}650 \\
660 \\
680 \\
690\end{array}$ & $\begin{array}{l}83.9 \\
81.2 \\
78.4 \\
75.8 \\
73.2\end{array}$ & $\begin{array}{l}90.2 \\
88.5 \\
85.9 \\
83.6 \\
81.5\end{array}$ & $\begin{array}{l}97.3 \\
96.6 \\
94.7 \\
93.5 \\
91.4\end{array}$ & $\begin{array}{l}93.75 \\
92.55 \\
90.30 \\
88.55 \\
86.45\end{array}$ & $\begin{array}{l}89.67 \\
88.52 \\
86.37 \\
84.70 \\
82.69\end{array}$ & $\begin{array}{l}78.56 \\
76.03 \\
73.41 \\
70.97 \\
68.54\end{array}$ \\
\hline 700 & $\begin{array}{l}70.5 \\
68.1 \\
65.8 \\
63.6 \\
61.3\end{array}$ & $\begin{array}{l}79.1 \\
76.5 \\
74.3 \\
72.0 \\
70.0\end{array}$ & $\begin{array}{l}89.3 \\
86.7 \\
84.8 \\
82.6 \\
80.5\end{array}$ & $\begin{array}{l}84.20 \\
81.60 \\
79.55 \\
77.30 \\
75.25\end{array}$ & $\begin{array}{l}80.54 \\
78.05 \\
76.09 \\
73.94 \\
71.98\end{array}$ & $\begin{array}{l}66.01 \\
63.76 \\
61.61 \\
59.55 \\
57.40\end{array}$ \\
\hline $750 \ldots$ & 59.4 & 67.9 & 78.5 & 73.20 & 70.01 & 55.62 \\
\hline
\end{tabular}

1 These values were submitted to the National Bureau of Standards by Dr. C. G. Abbot in letter of Nov. 7, 1917.

2 These values were computed from Abbot's data by the authors for the purposes of this investigation.

\section{(b) A STANDARD FOR SENSITOMETRY}

As previously noted, the American Committee on the Unit of Photographic Intensity originally recommended, and the Sixth International Congress of Photography tentatively adopted in 1925, $5,000^{\circ} \mathrm{K}$. as the primary standard of energy distribution for use in photographic sensitometry. The color of $5,000^{\circ} \mathrm{K}$. is not greatly different from that of average noon sunlight-it was, in fact, chosen for this reason. In addition, it serves as a precise definition and is a good round number. 
As a standard for use in photographic sensitometry, however, the authors believe their adopted mean sun is much preferable to $5,000^{\circ} \mathrm{K}$. The reasons are as follows:

1. In photographic sensitometry it is not the color that is primarily important but the energy distribution, particularly in the violet and near ultra-violet where all photographic materials are highly sensitive. In this important region the relative energy of $5,000^{\circ} \mathrm{K}$. is not representative of sunlight, as is shown in Figure 6.

2. The energy distribution of mean sun can be duplicated much more closely by means of incandescent lights and filters than can that of $5,000^{\circ} \mathrm{K}$. This is well illustrated by a comparison of charts 8 and 24 showing the energy distribution curves obtained with a $2,848^{\circ} \mathrm{K}$. source and the respective filters for obtaining mean sun and $5,000^{\circ} \mathrm{K}$. Not only are the deviations in the latter case much larger,

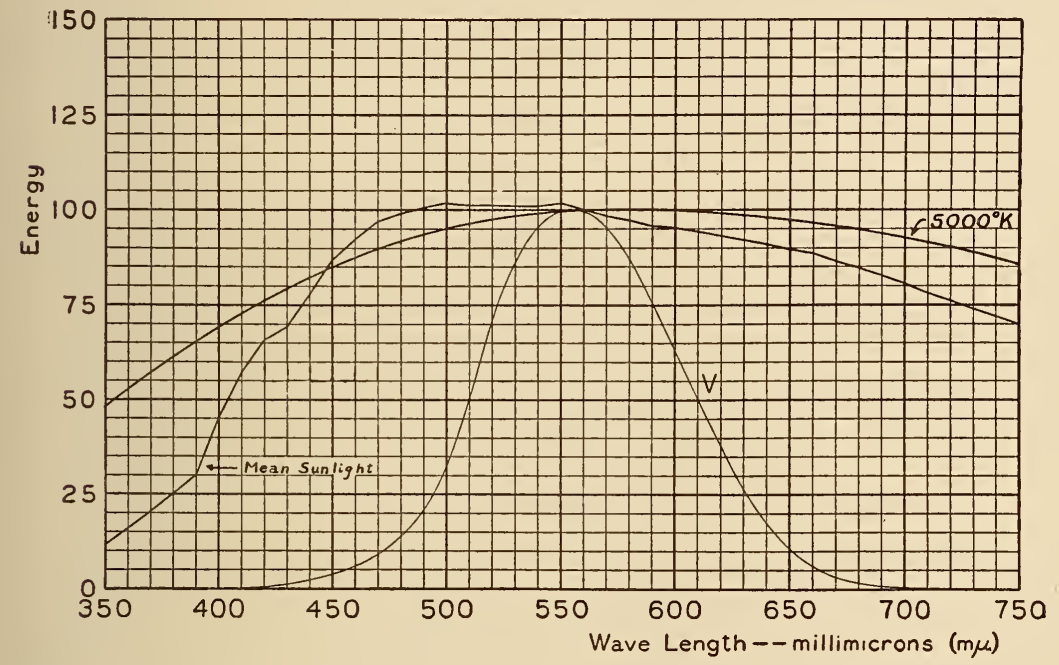

Figure 6.-Relative energy distributions of $5,000^{\circ} \mathrm{K}$. and mean sunlight

This shows that $5,000^{\circ} \mathrm{K}$. is not a satisfactory representation of sunlight in the photographically important region below $420 \mathrm{~m} \mu$.

but the transmission is lower; and this difficulty of reproducing $5,000^{\circ} \mathrm{K}$. from any practicable incandescent lamp color temperature, considering both the spectral energy match and the light transmission, is inherent in the differences in the energy distributions, not in the filters employed.

It seems undesirable to choose any ideal standard of energy distribution for use in photographic sensitometry which is less representative of natural sunlight conditions than the adopted mean sun, and which is at the same time less satisfactorily reproducible in the laboratory.

\section{SUNLIGHT OUTSIDE THE EARTH'S ATMOSPHERE-A STANDARD OF DAYLIGHT}

Certain problems may arise in colorimetry where a daylight filter may be preferred to a sunlight filter. However, the spectral energy distribution of daylight has apparently never been measured as such; 
indeed, there may be question as to the proper definition of daylight, which may show considerable variation in color, depending upon atmospheric conditions, time of day, and other factors.

Priest has previously shown $(28 ; 43$, p. 483) that the color temperature $\left(6,000^{\circ}\right.$ to $7,000^{\circ} \mathrm{K}$.) of the overcast sky is approximately the same as the color temperature of the sun as it would appear outside the earth's atmosphere. Priest's later data (28) also show that, for clear and partly cloudy skies, the color temperature of the combined light of sun and sky received on a horizontal surface exposed to the whole sky lies generally within this same range, $6,000^{\circ}$ to $7,000^{\circ} \mathrm{K}$., for a wide range of solar altitudes. Taylor's data ("The Color of Daylight," Tab. I, 23d Ann. Con. I. E. S.; 1929) are in substantial accord with Priest's. Kimball (29, p. 514) states (on the basis of Priest's color-match data and other data on spectral distribution): "Therefore, for the total daylight with either clear, cloudy, or partly cloudy skies the energy distribution corresponds closely to the distribution for black-body radiation at a temperature from $5,500^{\circ}$ to $6,500^{\circ} \mathrm{K}$."

As will be shown later in this paper, we have found by actual trial that the color of the overcast sky may be nearly matched by the color of the sun outside the earth's atmosphere. A filter was designed (Sec. V, 6) to convert $2,848^{\circ} \mathrm{K}$. to sunlight outside the atmosphere as specified by Abbot's data of 1917, given in Table 1. At certain times on four different days near the autumnal equinox of 1928 and once during the tests in December, 1928, a perfect color match was observed between this source-and-filter combination and overcast south sky, although on the average the two colors were not identical. Details of these measurements are given in Section VIII, 4.

\section{THE PLANCKIAN RADIATOR OR BLACK BODY}

\section{(a) AN EQUIVALENT OF INCANDESCENT ILLUMINANTS-COLOR TEMPERATURE}

The determination of spectral energy distribution by direct radiometric methods is a matter of considerable experimental difficulty, requiring elaborate apparatus and expert knowledge and technique. The problem is considerably simplified provided one has available a standardized source of accurately known spectral energy distribution; for in this case it is necessary merely to make comparison, wave length by wave length, visually or otherwise, of the unknown source with the standard, and various instrumental calibrations necessary in direct radiometric measurements are eliminated. At best, however, it is a laborious undertaking to make spectral energy determinations by spectrophotometric or spectroradiometric methods.

However, a substitute method is available, involving much less apparatus, time, and skill, in which the spectral energy distribution is derived by determining what is known as the color temperature of the source. The relative energy distribution from a complete radiator or black body is a function only of the temperature of the radiator. The theoretical equation derived by Planck expressing this relation is of the form; 


$$
E_{\lambda}=\frac{C_{1} \lambda^{-5}}{e^{\lambda \theta}-1}
$$

where

$E_{\lambda}$ is the energy per unit wave length at wave length $\lambda$,

$\theta$ is the absolute temperature in ${ }^{\circ} \mathrm{K} .\left({ }^{\circ} \mathrm{C} .+273\right)$,

$e$ is the base of natural logarithms, and

$C_{1}$ and $C_{2}$ are constants.

It has been found by experiment that the relative energy distribution from many common incandescent light sources in the visible spectrum is practically the same as that from a Planckian radiator, provided the temperature of the latter is taken to give an accurate color match with the source in question. The color temperature of a light source is defined (30, p. 1180) as "the temperature at which a Planckian radiator would emit radiant energy competent to evoke a color of the same quality as that evoked by the radiant energy from the source in question." A light source accurately allocated on the color temperature scale-that is, having a perfect color match with the Planckian radiator at some temperature-may or may not have an exact relative spectral energy match with this ideal radiator.

The practical advantage of the color-temperature method as a substitute for spectral energy determinations lies in the fact, noted above, that many common illuminants, particularly incandescent electric lamps, not only give a good color match with the Planckian radiator but a very close approximation, at least in the visible spectrum, to the relative energy distribution as well. This approximation is so good that a specification of color temperature serves in practically all cases as an adequate specification of the relative spectral energy values.

Of course, there are certain sources, such as the mercury arc, which can not be described in terms of color temperature, and others, such as the Welsbach mantle, which can be placed only crudely on the color temperature scale, not being a match with any black-body color. However, practically all sources whose light is produced solely by temperature may be quite accurately described in terms of color temperature. Passing over the varying red shades of the furnace, we may note as reference points the approximate color temperatures of various illuminants - the candle and kerosene flames at $1,900^{\circ} \mathrm{K}$., the carbon lamp at $2,100^{\circ} \mathrm{K}$., the acetylene flame ${ }^{7}$ and racuum tungsten lamp at $2,400^{\circ} \mathrm{K}$., and the gas-filled tungsten lamps from $2,600^{\circ}$ to $3,100^{\circ} \mathrm{K}$. In the case of flames, the values vary for different portions of the flame and for different conditions of pressure, humidity, etc. With the incandescent electric lamps, the values differ with the applied voltage and with the type of lamp, the effective portion of the filament, etc. The melting point of tungsten is near $3,600^{\circ} \mathrm{K}$., which is approximately the color temperature of the low power carbon arc. For more complete discussions of color temperature the reader is referred to papers from the Nela Research Laboratory (31) and from the National Bureau of Standards (30), and to references contained therein. An illustration

\footnotetext{
${ }^{7}$ See Sec. III, 4 for discussion of the acetylene flame.
} 
(fig. 7) from one of the bureau papers (Sci. Pap. No. 443, fig. 1, p. 225) will serve to illustrate the sort of deviations which may be expected in the case of incandescent electric lamps between experimental determinations of spectral energy distribution and values computed from Planck's equation.

Such actual experimental determinations of spectral energy distribution would be all too meager for the needs of the present paper. Furthermore, they are subject to experimental uncertainty, especially at the shorter wave lengths where the energy values are relatively small. It has, therefore, been not only preferable, but necessary, to use the theoretical values given by Planck's equation in

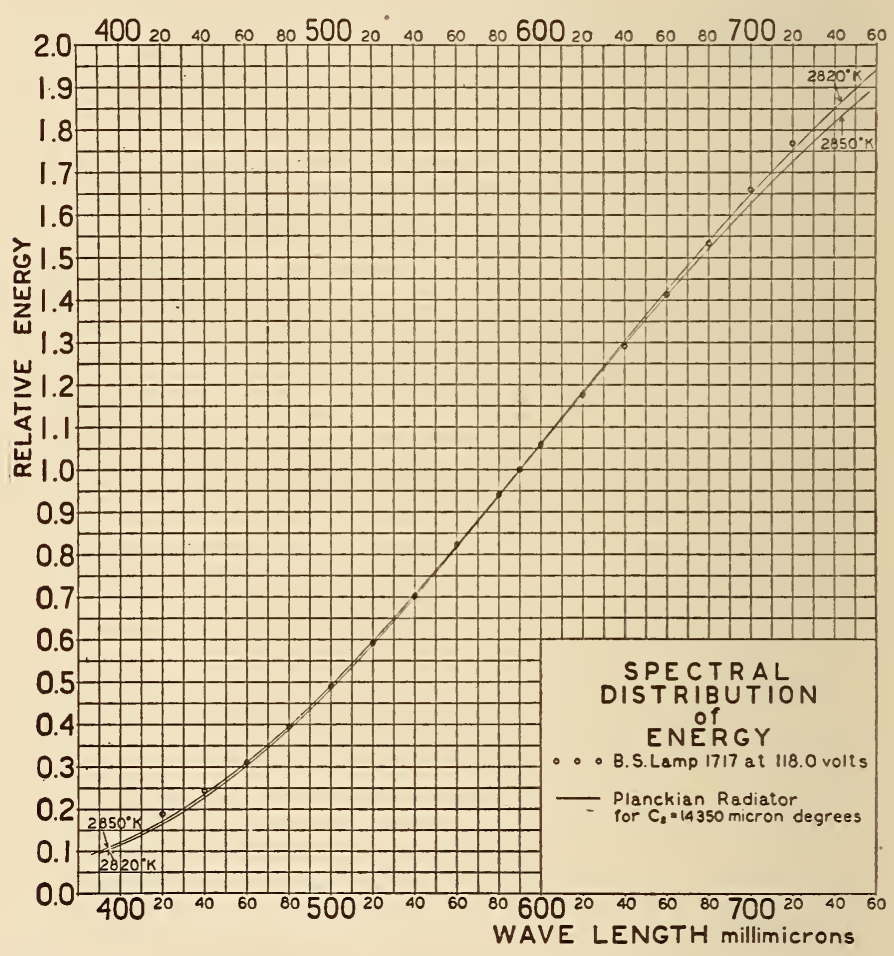

Figdre 7.-Relative energy distribution of standard lamp, B. S. 1717 , at 118.0 volts, compared with Planckian radiator at $2,820^{\circ}$ and $2,850^{\circ} \mathrm{K}$.

This illustration is reproduced from B. S. Sci. paper No. 443, by I. G. Priest.

the computation of the filters to be described, with the exception of the acetylene-to-sunlight filter.

(b) ENERGY DISTRIBUTIONS, $2,000^{\circ}$ TO $20,000^{\circ} \mathrm{K}$.

Relative spectral energy data computed from Planck's (or Wien's) equation have been published by various investigators. The most extensive of these data ${ }^{8}$ comprise Bureau of Standards Miscellaneous

8 See also a paper by Skogland entitled, "Tables of Spectral Energy Distribution and Luminosity for Use in Computing Light Transmissions and Relative Brightnesses from Spectrophotometric Data," B. S. Misc. Pub. No. 86; 1929 . These tables cover the range from $2,000^{\circ}$ to $3,120^{\circ} \mathrm{K}$., at $20^{\circ} \mathrm{K}$. intervals for the energy distributions and at $80^{\circ} \mathrm{K}$. intervals for the luminosity data, differences for interpolation being also given. These tables are based on $14,330 \mu^{\circ}$ as the value of $C_{2}$. 
Publication No. 56 (hereinafter designated as M56), by Frehafer and Snow, entitled "Tables and Graphs for Facilitating the Computation of Spectral Energy Distribution by Planck's Formula." By means of these tables and graphs, Planckian energy distributions over a wave length range from $400 \mathrm{~m} \mu$ to $720 \mathrm{~m} \mu$ may be readily obtained for all color temperatures from $1,000^{\circ}$ to $28,000^{\circ} \mathrm{K}$. A table is also given by means of which with further computation values may be obtained at wave lengths beyond this range. The value of $C_{2}$ used in these computations was $14,350 \mu^{\circ}$. The graphs are so arranged, however, that values may readily be obtained for any reasonable value of $C_{2}$. The accuracy claimed for these computations was in general 0.15 per cent or better for the tables and 0.33 per cent or better for the graphs.

TABLE 2.- Spectral encrgy distribution of a Planckian radiator or black body at various temperatures

\begin{tabular}{|c|c|c|c|c|c|c|c|c|}
\hline \multirow{2}{*}{$\begin{array}{l}\text { Wave length in } \\
\text { millimicrons }\end{array}$} & \multicolumn{8}{|c|}{ Relative energy distribution ${ }^{1}$ at- } \\
\hline & $2,000^{\circ} \mathrm{K}$. & $2,100^{\circ} \mathrm{K}$. & $2,200^{\circ} \mathrm{K}$ & $2,300^{\circ} \mathrm{K}$ & $2,360^{\circ} \mathrm{K}$. & $2,400^{\circ} \mathrm{K}$ & $2,450^{\circ} \mathrm{K}$ & $2,500^{\circ} \mathrm{K}$. \\
\hline 390 & $\begin{array}{r}0.48 \\
.74 \\
1.10 \\
1.61 \\
2.29\end{array}$ & $\begin{array}{l}0.69 \\
1.04 \\
1.51 \\
2.15 \\
2.99\end{array}$ & $\begin{array}{l}0.96 \\
1.41 \\
2.00 \\
2.79 \\
3.81\end{array}$ & $\begin{array}{l}1.31 \\
1.86 \\
2.60 \\
3.54 \\
4.74\end{array}$ & $\begin{array}{l}1.55 \\
2.19 \\
3.01 \\
4.06 \\
5.38\end{array}$ & $\begin{array}{l}1.73 \\
2.42 \\
3.31 \\
4.42 \\
5.81\end{array}$ & $\begin{array}{l}1.97 \\
2.73 \\
3.69 \\
4.90 \\
6.40\end{array}$ & $\begin{array}{l}2.24 \\
3.06 \\
4.11 \\
5.41 \\
7.00\end{array}$ \\
\hline 430 & $\begin{array}{r}3.19 \\
4.37 \\
5.88 \\
7.78 \\
10.14\end{array}$ & $\begin{array}{r}4.09 \\
5.45 \\
7.20 \\
9.36 \\
11.98\end{array}$ & $\begin{array}{r}5.10 \\
6.71 \\
8.68 \\
11.08 \\
13.94\end{array}$ & $\begin{array}{r}6.24 \\
8.08 \\
10.26 \\
12.92 \\
16.00\end{array}$ & $\begin{array}{r}6.99 \\
8.94 \\
11.29 \\
14.06 \\
17.28\end{array}$ & $\begin{array}{r}7.51 \\
9.55 \\
12.00 \\
14.85 \\
18.16\end{array}$ & $\begin{array}{r}8.18 \\
10.34 \\
12.91 \\
15.87 \\
19.26\end{array}$ & $\begin{array}{r}8.89 \\
11.15 \\
13.83 \\
16.90 \\
20.38\end{array}$ \\
\hline $480 \ldots$ & $\begin{array}{l}13.01 \\
16.49 \\
20.63 \\
25.52 \\
31.24\end{array}$ & $\begin{array}{l}15.12 \\
18.84 \\
23.22 \\
28.31 \\
34.11\end{array}$ & $\begin{array}{l}17.32 \\
21.26 \\
25.82 \\
31.03 \\
36.92\end{array}$ & $\begin{array}{l}19.60 \\
23.75 \\
28.46 \\
33.79 \\
39.67\end{array}$ & $\begin{array}{l}21.00 \\
25.22 \\
30.03 \\
35.37 \\
41.32\end{array}$ & $\begin{array}{l}21.95 \\
26.25 \\
31.07 \\
36.45 \\
42.39\end{array}$ & $\begin{array}{l}23.13 \\
27.50 \\
32.40 \\
37.80 \\
43.77\end{array}$ & $\begin{array}{l}24.33 \\
28.76 \\
33.71 \\
39.12 \\
45.08\end{array}$ \\
\hline 530 & $\begin{array}{l}37.85 \\
45.40 \\
54.03 \\
63.70 \\
74.49\end{array}$ & $\begin{array}{l}40.76 \\
48.25 \\
56.70 \\
65.90 \\
76.35\end{array}$ & $\begin{array}{l}43.55 \\
50.95 \\
59.13 \\
68.06 \\
77.94\end{array}$ & $\begin{array}{l}46.31 \\
53.60 \\
61.50 \\
70.00 \\
79.35\end{array}$ & $\begin{array}{l}47.88 \\
55.08 \\
62.84 \\
71.18 \\
80.23\end{array}$ & $\begin{array}{l}48.95 \\
56.03 \\
63.67 \\
71.92 \\
80.72\end{array}$ & $\begin{array}{l}50.20 \\
57.25 \\
64.80 \\
72.75 \\
81.35\end{array}$ & $\begin{array}{l}51.45 \\
58.45 \\
65.80 \\
73.60 \\
82.00\end{array}$ \\
\hline $\begin{array}{l}570 \ldots \\
580 \ldots \\
590 \ldots\end{array}$ & $\begin{array}{r}86.57 \\
100.00 \\
114.5 \\
130.5 \\
147.7\end{array}$ & $\begin{array}{r}87.60 \\
100.00 \\
113.3 \\
127.8 \\
143.2\end{array}$ & $\begin{array}{c}88.52 \\
100.00 \\
112.3 \\
125.4 \\
139.3\end{array}$ & $\begin{array}{r}89.30 \\
100.00 \\
111.3 \\
123.2 \\
135.8\end{array}$ & $\begin{array}{r}89.74 \\
100.00 \\
110.68 \\
122.06 \\
133.78\end{array}$ & $\begin{array}{r}90.04 \\
100.00 \\
110.4 \\
121.2 \\
132.6\end{array}$ & $\begin{array}{r}90.45 \\
100.00 \\
109.9 \\
120.3 \\
131.1\end{array}$ & $\begin{array}{r}90.75 \\
100.00 \\
109.5 \\
119.5 \\
129.7\end{array}$ \\
\hline $\begin{array}{l}620 \ldots \\
630 \ldots \\
640 .\end{array}$ & $\begin{array}{l}166.3 \\
186.3 \\
207.7 \\
230.2 \\
254.3\end{array}$ & $\begin{array}{l}159.7 \\
177.2 \\
195.8 \\
215.0 \\
235.5\end{array}$ & $\begin{array}{l}153.9 \\
169.5 \\
185.5 \\
202.4 \\
220.0\end{array}$ & $\begin{array}{l}148.8 \\
162.5 \\
176.6 \\
191.3 \\
206.4\end{array}$ & $\begin{array}{l}146.07 \\
158.77 \\
171.96 \\
185.35 \\
199.24\end{array}$ & $\begin{array}{l}144.2 \\
156.4 \\
168.9 \\
181.7 \\
194.7\end{array}$ & $\begin{array}{l}142.1 \\
153.6 \\
165.4 \\
177.3 \\
189.5\end{array}$ & $\begin{array}{l}140.2 \\
151.0 \\
162.1 \\
173.2 \\
184.6\end{array}$ \\
\hline 650 & $\begin{array}{l}279.4 \\
306.0 \\
334.0 \\
362.9 \\
393.1\end{array}$ & $\begin{array}{l}256.8 \\
279.5 \\
302.0 \\
325.5 \\
350.0\end{array}$ & $\begin{array}{l}238.2 \\
256.9 \\
276.0 \\
295.7 \\
316.2\end{array}$ & $\begin{array}{l}221.9 \\
237.7 \\
253.9 \\
270.2 \\
287.1\end{array}$ & $\begin{array}{l}213.36 \\
227.83 \\
242.64 \\
257.36 \\
272.47\end{array}$ & $\begin{array}{l}208.1 \\
221.8 \\
235.5 \\
249.3 \\
263.1\end{array}$ & $\begin{array}{l}201.9 \\
214.6 \\
227.4 \\
239.7 \\
252.3\end{array}$ & $\begin{array}{l}196.2 \\
207.9 \\
219.7 \\
231.2 \\
242.7\end{array}$ \\
\hline $\begin{array}{l}700 \\
710\end{array}$ & $\begin{array}{l}424.7 \\
456.8 \\
490.1\end{array}$ & $\begin{array}{l}376.5 \\
402.0 \\
428.0\end{array}$ & $\begin{array}{l}336.8 \\
357.6 \\
378.6\end{array}$ & $\begin{array}{l}304.5 \\
321.0 \\
338.0\end{array}$ & $\begin{array}{l}287.56 \\
302.64 \\
317.87\end{array}$ & $\begin{array}{l}277.2 \\
291.1 \\
305.2\end{array}$ & $\begin{array}{l}265.2 \\
277.9 \\
290.7\end{array}$ & $\begin{array}{l}254.4 \\
266.2 \\
277.4\end{array}$ \\
\hline
\end{tabular}

(See footnote at end of table.) 
TABLE 2.-Spectral energy distribution of a Planckian radiator or black body at various temperatures-Continued

\begin{tabular}{|c|c|c|c|c|c|c|c|c|}
\hline \multirow{2}{*}{$\begin{array}{l}\text { Wave length in } \\
\text { millimicrons }\end{array}$} & \multicolumn{8}{|c|}{ Relative energy distribution ${ }^{1}$ at- } \\
\hline & $2,600^{\circ} \mathrm{K}$ & $2,700^{\circ} \mathrm{K}$ & $2,800^{\circ} \mathrm{K}$. & $2,848^{\circ} \mathrm{K}$ & $2,900^{\circ} \mathrm{K}$. & $3,000^{\circ} \mathrm{K}$. & $3,100^{\circ} \mathbf{K}$ & $3,200^{\circ} \mathrm{K}$ \\
\hline $\begin{array}{l}350 \\
360 \\
370 \\
380 \\
390\end{array}$ & $\begin{array}{l}2.84 \\
3.81 \\
5.03 \\
6.52 \\
8.33\end{array}$ & $\begin{array}{l}3.52 \\
4.67 \\
6.07 \\
7.76 \\
9.74\end{array}$ & $\begin{array}{r}4.32 \\
5.64 \\
7.22 \\
9.11 \\
11.30\end{array}$ & $\begin{array}{r}4.75 \\
6.16 \\
7.82 \\
9.79 \\
12.09\end{array}$ & $\begin{array}{r}5.23 \\
6.71 \\
8.50 \\
10.58 \\
12.96\end{array}$ & $\begin{array}{r}6.22 \\
7.92 \\
9.88 \\
12.15 \\
14.74\end{array}$ & $\begin{array}{r}7.36 \\
9.22 \\
11.39 \\
13.86 \\
16.65\end{array}$ & $\begin{array}{r}8.58 \\
10.64 \\
13.00 \\
15.66 \\
18.60\end{array}$ \\
\hline $\begin{array}{l}400 \\
410 \\
420\end{array}$ & $\begin{array}{l}10.44 \\
12.91 \\
15.78 \\
19.03 \\
22.71\end{array}$ & $\begin{array}{l}12.10 \\
14.76 \\
17.82 \\
21.24 \\
25.09\end{array}$ & $\begin{array}{l}13.82 \\
16.71 \\
19.94 \\
23.54 \\
27.52\end{array}$ & $\begin{array}{l}14.71 \\
17.69 \\
21.00 \\
24.68 \\
28.73\end{array}$ & $\begin{array}{l}15.68 \\
18.75 \\
22.15 \\
25.91 \\
30.01\end{array}$ & $\begin{array}{l}17.66 \\
20.87 \\
24.44 \\
28.33 \\
32.52\end{array}$ & $\begin{array}{l}19.74 \\
23.10 \\
26.81 \\
30.80 \\
35.05\end{array}$ & $\begin{array}{l}21.87 \\
25.40 \\
29.20 \\
33.30 \\
37.60\end{array}$ \\
\hline $\begin{array}{l}450 \ldots \\
460 \\
470 \\
480 \\
490 \\
4\end{array}$ & $\begin{array}{l}26.83 \\
31.36 \\
36.38 \\
41.80 \\
47.69\end{array}$ & $\begin{array}{l}29.33 \\
33.97 \\
38.99 \\
44.45 \\
50.25\end{array}$ & $\begin{array}{l}31.86 \\
36.55 \\
41.60 \\
47.03 \\
52.71\end{array}$ & $\begin{array}{l}33.11 \\
37.81 \\
42.87 \\
48.27 \\
53.92\end{array}$ & $\begin{array}{l}34.43 \\
39.16 \\
44.24 \\
49.59 \\
55.15\end{array}$ & $\begin{array}{l}36.99 \\
41.78 \\
46.81 \\
52.08 \\
57.54\end{array}$ & $\begin{array}{l}39.50 \\
44.35 \\
49.35 \\
54.50 \\
59.85\end{array}$ & $\begin{array}{l}42.17 \\
46.89 \\
51.80 \\
56.85 \\
62.15\end{array}$ \\
\hline $\begin{array}{l}500 \\
510 \\
530 \\
540\end{array}$ & $\begin{array}{l}53.99 \\
60.75 \\
67.88 \\
75.37 \\
83.26\end{array}$ & $\begin{array}{l}56.50 \\
63.00 \\
69.85 \\
76.90 \\
84.35\end{array}$ & $\begin{array}{l}58.78 \\
65.08 \\
71.64 \\
78.45 \\
85.45\end{array}$ & $\begin{array}{l}59.90 \\
66.08 \\
72.51 \\
79.16 \\
85.97\end{array}$ & $\begin{array}{l}61.10 \\
67.15 \\
73.40 \\
79.80 \\
86.45\end{array}$ & $\begin{array}{l}63.22 \\
69.11 \\
75.08 \\
81.23 \\
87.43\end{array}$ & $\begin{array}{l}65.35 \\
71.00 \\
76.70 \\
82.45 \\
88.30\end{array}$ & $\begin{array}{l}67.40 \\
72.80 \\
78.20 \\
83.70 \\
89.15\end{array}$ \\
\hline $\begin{array}{l}550 \\
560 \\
580 \\
590\end{array}$ & $\begin{array}{l}91.49 \\
100.00 \\
108.8 \\
117.9 \\
127.1\end{array}$ & $\begin{array}{l}92.10 \\
100.00 \\
108.1 \\
116.4 \\
124.8\end{array}$ & $\begin{array}{l}92.68 \\
100.00 \\
107.4 \\
115.1 \\
122.7\end{array}$ & $\begin{array}{r}92.97 \\
100.00 \\
107.20 \\
114.52 \\
121.80\end{array}$ & $\begin{array}{l}93.25 \\
100.00 \\
106.8 \\
113.8 \\
120.7\end{array}$ & $\begin{array}{l}93.71 \\
100.00 \\
106.3 \\
112.7 \\
119.0\end{array}$ & $\begin{array}{l}94.15 \\
100.00 \\
105.7 \\
111.6 \\
117.3\end{array}$ & $\begin{array}{l}94.60 \\
100.00 \\
105.3 \\
110.6 \\
115.8\end{array}$ \\
\hline $\begin{array}{l}600 \\
610 \\
620 \\
630 \\
610\end{array}$ & $\begin{array}{l}136.6 \\
146.3 \\
156.1 \\
165.9 \\
175.9\end{array}$ & $\begin{array}{l}133.3 \\
141.9 \\
150.6 \\
159.3 \\
168.0\end{array}$ & $\begin{array}{l}130.4 \\
138.1 \\
145.8 \\
153.5 \\
161.1\end{array}$ & $\begin{array}{l}129.07 \\
136.42 \\
143.64 \\
150.88 \\
158.06\end{array}$ & $\begin{array}{l}127.7 \\
134.6 \\
141.4 \\
148.2 \\
154.9\end{array}$ & $\begin{array}{l}125.3 \\
131.5 \\
137.5 \\
143.4 \\
149.3\end{array}$ & $\begin{array}{l}123.0 \\
128.6 \\
133.8 \\
139.0 \\
144.3\end{array}$ & $\begin{array}{l}120.9 \\
125.8 \\
130.6 \\
135.1 \\
139.8\end{array}$ \\
\hline $\begin{array}{l}650 \\
660 \\
680 \\
690\end{array}$ & $\begin{array}{l}185.9 \\
195.7 \\
205.8 \\
215.6 \\
225.6\end{array}$ & $\begin{array}{l}176.6 \\
185.3 \\
193.6 \\
202.2 \\
210.5\end{array}$ & $\begin{array}{l}168.6 \\
176.1 \\
183.2 \\
190.5 \\
197.5\end{array}$ & $\begin{array}{l}165.08 \\
172.12 \\
178.87 \\
185.52 \\
192.13\end{array}$ & $\begin{array}{l}161.4 \\
167.8 \\
174.0 \\
180.2 \\
186.1\end{array}$ & $\begin{array}{l}155.0 \\
160.5 \\
166.0 \\
171.2 \\
176.3\end{array}$ & $\begin{array}{l}149.2 \\
153.9 \\
158.7 \\
163.2 \\
167.4\end{array}$ & $\begin{array}{l}144.0 \\
148.1 \\
152.1 \\
155.9 \\
159.4\end{array}$ \\
\hline $\begin{array}{l}700 \\
710 \\
720\end{array}$ & $\begin{array}{l}235.3 \\
244.9 \\
254.4\end{array}$ & $\begin{array}{l}218.6 \\
226.6 \\
234.5\end{array}$ & $\begin{array}{l}204.4 \\
211.3 \\
217.7\end{array}$ & $\begin{array}{l}198.32 \\
204.49 \\
210.57\end{array}$ & $\begin{array}{l}192.1 \\
197.6 \\
203.0\end{array}$ & $\begin{array}{l}181.2 \\
185.8 \\
190.1\end{array}$ & $\begin{array}{l}171.5 \\
175.3 \\
178.8\end{array}$ & $\begin{array}{l}162.8 \\
166.0 \\
168.9\end{array}$ \\
\hline
\end{tabular}

\begin{tabular}{|c|c|c|c|c|c|c|c|c|}
\hline \multirow{2}{*}{$\begin{array}{l}\text { Wave length in } \\
\text { millimicrons }\end{array}$} & \multicolumn{8}{|c|}{ Relative energy distribution 1 at- } \\
\hline & $3,250^{\circ} \mathrm{K}$. & $3,300^{\circ} \mathbf{K}$. & $3,400^{\circ} \mathrm{K}$. & $3,500^{\circ} \mathrm{K}$. & $3,600^{\circ} \mathrm{K}$. & $3,700^{\circ} \mathrm{K}$. & $3,750^{\circ} \mathrm{K}$. & $3,800^{\circ} \mathrm{K}$. \\
\hline $\begin{array}{l}350 \\
360 \\
370 \\
380 \\
390\end{array}$ & $\begin{array}{r}9.26 \\
11.40 \\
13.86 \\
16.60 \\
19.63\end{array}$ & $\begin{array}{r}9.93 \\
12.18 \\
14.72 \\
17.55 \\
20.66\end{array}$ & $\begin{array}{l}11.40 \\
13.83 \\
16.55 \\
19.56 \\
22.83\end{array}$ & $\begin{array}{l}12.97 \\
15.58 \\
18.49 \\
21.66 \\
25.06\end{array}$ & $\begin{array}{l}14.64 \\
17.44 \\
20.52 \\
23.82 \\
27.42\end{array}$ & $\begin{array}{l}16.43 \\
19.41 \\
22.63 \\
26.13 \\
29.77\end{array}$ & $\begin{array}{l}17.36 \\
20.42 \\
23.73 \\
27.28 \\
31.00\end{array}$ & $\begin{array}{l}18.32 \\
21.45 \\
24.87 \\
28.42 \\
32.23\end{array}$ \\
\hline $\begin{array}{l}400 \ldots \\
410 \ldots- \\
420 \ldots \\
430 \ldots- \\
440 \ldots\end{array}$ & $\begin{array}{l}22.97 \\
26.57 \\
30.42 \\
34.56 \\
38.88\end{array}$ & $\begin{array}{l}24.06 \\
27.73 \\
31.65 \\
35.80 \\
40.19\end{array}$ & $\begin{array}{l}26.36 \\
30.14 \\
34.15 \\
38.32 \\
42.73\end{array}$ & $\begin{array}{l}28.73 \\
32.60 \\
36.67 \\
40.90 \\
45.30\end{array}$ & $\begin{array}{l}31.17 \\
35.10 \\
39.23 \\
43.50 \\
47.84\end{array}$ & $\begin{array}{l}33.65 \\
37.67 \\
41.83 \\
46.08 \\
50.35\end{array}$ & $\begin{array}{l}34.90 \\
38.98 \\
43.14 \\
47.41 \\
51.72\end{array}$ & $\begin{array}{l}36.17 \\
40.29 \\
44.45 \\
48.72 \\
53.00\end{array}$ \\
\hline $\begin{array}{l}450 \\
460 \\
480 \\
490\end{array}$ & $\begin{array}{l}43.43 \\
48.15 \\
53.03 \\
58.07 \\
63.21\end{array}$ & $\begin{array}{l}44.73 \\
49.37 \\
54.25 \\
59.20 \\
64.30\end{array}$ & $\begin{array}{l}47.28 \\
51.80 \\
56.65 \\
61.45 \\
66.40\end{array}$ & $\begin{array}{l}49.79 \\
54.38 \\
59.06 \\
63.70 \\
68.47\end{array}$ & $\begin{array}{l}52.30 \\
56.80 \\
61.30 \\
65.85 \\
70.45\end{array}$ & $\begin{array}{l}54.85 \\
59.20 \\
63.65 \\
68.05 \\
72.40\end{array}$ & $\begin{array}{l}56.08 \\
60.45 \\
64.80 \\
69.14 \\
73.34\end{array}$ & $\begin{array}{l}57.40 \\
61.60 \\
65.85 \\
70.15 \\
74.30\end{array}$ \\
\hline 520 & $\begin{array}{l}68.41 \\
73.67 \\
79.01 \\
84.29 \\
89.56\end{array}$ & $\begin{array}{l}69.35 \\
74.50 \\
79.65 \\
84.80 \\
89.90\end{array}$ & $\begin{array}{l}71.25 \\
76.15 \\
81.05 \\
85.90 \\
90.70\end{array}$ & $\begin{array}{l}73.14 \\
77.82 \\
82.39 \\
86.94 \\
91.36\end{array}$ & $\begin{array}{l}74.95 \\
79.30 \\
83.65 \\
87.95 \\
92.10\end{array}$ & $\begin{array}{l}76.70 \\
80.85 \\
84.90 \\
88.90 \\
92.70\end{array}$ & $\begin{array}{l}77.57 \\
81.63 \\
85.56 \\
89.40 \\
93.10\end{array}$ & $\begin{array}{l}78.40 \\
82.30 \\
86.15 \\
89.85 \\
93.35\end{array}$ \\
\hline
\end{tabular}

(See footnote at end of table.) 
TABLE 2.-Spectral energy distribution of a Planckian radiator or black body at various temperatures-Continued

\begin{tabular}{|c|c|c|c|c|c|c|c|c|}
\hline \multirow{2}{*}{$\begin{array}{l}\text { Wave length in } \\
\text { millimicrons }\end{array}$} & \multicolumn{8}{|c|}{ Relative energy distribution ${ }^{1}$ at- } \\
\hline & $3,250^{\circ} \mathrm{K}$. & $3,300^{\circ} \mathrm{K}$. & $3,400^{\circ} \mathrm{K}$. & $3,500^{\circ} \mathrm{K}$. & $3,600^{\circ} \mathrm{K}$. & $3,700^{\circ} \mathrm{K}$. & $3,750^{\circ} \mathrm{K}$ & $3,800^{\circ} \mathrm{K}$. \\
\hline $\begin{array}{l}550 \\
560 \ldots \\
570 \ldots \\
580 \ldots \\
590\end{array}$ & $\begin{array}{c}94.84 \\
100.00 \\
105.1 \\
110.2 \\
115.1\end{array}$ & $\begin{array}{l}95.00 \\
100.00 \\
104.8 \\
109.7 \\
114.4\end{array}$ & $\begin{array}{r}95.35 \\
100.00 \\
104.4 \\
108.8 \\
113.0\end{array}$ & $\begin{array}{r}95.69 \\
100.00 \\
104.0 \\
108.0 \\
111.8\end{array}$ & $\begin{array}{r}96.10 \\
100.00 \\
103.6 \\
107.2 \\
110.6\end{array}$ & $\begin{array}{r}96.40 \\
100.00 \\
103.2 \\
106.5 \\
109.5\end{array}$ & $\begin{array}{c}96.55 \\
100.00 \\
103.1 \\
106.2 \\
109.0\end{array}$ & $\begin{array}{r}96.70 \\
100.00 \\
102.9 \\
105.8 \\
108.5\end{array}$ \\
\hline $\begin{array}{l}600 \\
610 \\
620 \\
630 \\
640\end{array}$ & $\begin{array}{l}119.9 \\
124.6 \\
129.0 \\
133.3 \\
137.6\end{array}$ & $\begin{array}{l}118.9 \\
123.4 \\
127.5 \\
131.5 \\
135.6\end{array}$ & $\begin{array}{l}117.1 \\
121.0 \\
124.6 \\
128.2 \\
131.8\end{array}$ & $\begin{array}{l}115.4 \\
118.9 \\
122.1 \\
125.2 \\
128.2\end{array}$ & $\begin{array}{l}113.8 \\
116.9 \\
119.7 \\
122.4 \\
125.0\end{array}$ & $\begin{array}{l}112.4 \\
115.1 \\
117.5 \\
119.9 \\
122.1\end{array}$ & $\begin{array}{l}111.7 \\
114.3 \\
116.5 \\
118.7 \\
120.7\end{array}$ & $\begin{array}{l}111.1 \\
113.4 \\
115.5 \\
117.5 \\
119.3\end{array}$ \\
\hline $\begin{array}{l}650 \ldots \\
660 \ldots \\
670 \ldots \\
680 \ldots \\
690\end{array}$ & $\begin{array}{l}141.6 \\
145.4 \\
149.1 \\
152.6 \\
155.8\end{array}$ & $\begin{array}{l}139.3 \\
142.8 \\
146.2 \\
149.4 \\
152.3\end{array}$ & $\begin{array}{l}135.0 \\
137.9 \\
140.8 \\
143.4 \\
145.9\end{array}$ & $\begin{array}{l}130.9 \\
133.5 \\
135.9 \\
138.1 \\
140.1\end{array}$ & $\begin{array}{l}127.3 \\
129.5 \\
131.4 \\
133.2 \\
134.8\end{array}$ & $\begin{array}{l}124.0 \\
125.7 \\
127.3 \\
128.8 \\
130.1\end{array}$ & $\begin{array}{l}122.4 \\
124.0 \\
125.4 \\
126.7 \\
127.9\end{array}$ & $\begin{array}{l}120.9 \\
122.3 \\
123.6 \\
124.8 \\
125.8\end{array}$ \\
\hline 700 & $\begin{array}{l}158.8 \\
161.8 \\
164.4\end{array}$ & $\begin{array}{l}155.0 \\
157.7 \\
160.0\end{array}$ & $\begin{array}{l}148.2 \\
150.2 \\
152.2\end{array}$ & $\begin{array}{l}142.0 \\
143.6 \\
145.1\end{array}$ & $\begin{array}{l}136.3 \\
137.6 \\
138.8\end{array}$ & $\begin{array}{l}131.2 \\
132.2 \\
133.0\end{array}$ & $\begin{array}{l}128.8 \\
129.7 \\
130.4\end{array}$ & $\begin{array}{l}126.6 \\
127.3 \\
127.8\end{array}$ \\
\hline
\end{tabular}

\begin{tabular}{|c|c|c|c|c|c|c|c|c|}
\hline \multirow{2}{*}{$\begin{array}{l}\text { Wave length in } \\
\text { millimicrons }\end{array}$} & \multicolumn{8}{|c|}{ Relative energy distribution ${ }^{1}$ at- } \\
\hline & $3,900^{\circ} \mathrm{K}$. & $4,000^{\circ} \mathrm{K}$. & $4,500^{\circ} \mathrm{K}$. & $5,000^{\circ} \mathrm{K}$. & $5,500^{\circ} \mathrm{K}$. & $6,000^{\circ} \mathrm{K}$. & $6,500^{\circ} \mathrm{K}$. & $7,000^{\circ} \mathrm{K}$ \\
\hline $\begin{array}{l}350 \ldots \\
360 \ldots \\
370 \ldots- \\
380 \ldots \\
390 \ldots \\
390 .-\end{array}$ & $\begin{array}{l}20.29 \\
23.64 \\
27.14 \\
30.88 \\
34.76\end{array}$ & $\begin{array}{l}22.42 \\
25.84 \\
29.56 \\
33.41 \\
37.36\end{array}$ & $\begin{array}{l}34.32 \\
38.37 \\
42.50 \\
46.69 \\
50.86\end{array}$ & $\begin{array}{l}48.17 \\
52.55 \\
56.84 \\
61.02 \\
65.04\end{array}$ & $\begin{array}{l}63.48 \\
67.85 \\
71.95 \\
75.85 \\
79.43\end{array}$ & $\begin{array}{l}79.83 \\
83.86 \\
87.51 \\
90.82 \\
93.74\end{array}$ & $\begin{array}{c}96.73 \\
100.1 \\
103.1 \\
105.7 \\
107.7\end{array}$ & $\begin{array}{l}113.9 \\
116.5 \\
118.5 \\
120.1 \\
121.2\end{array}$ \\
\hline $\begin{array}{l}400 \ldots \\
410-. \\
420- \\
430 \\
440 \\
4\end{array}$ & $\begin{array}{l}38.72 \\
42.90 \\
47.05 \\
51.30 \\
55.55\end{array}$ & $\begin{array}{l}41.39 \\
45.54 \\
49.70 \\
53.92 \\
58.13\end{array}$ & $\begin{array}{l}54.95 \\
58.97 \\
62.91 \\
66.76 \\
70.48\end{array}$ & $\begin{array}{l}68.91 \\
72.54 \\
76.00 \\
79.23 \\
82.17\end{array}$ & $\begin{array}{l}82.72 \\
85.73 \\
88.50 \\
90.90 \\
93.05\end{array}$ & $\begin{array}{c}96.37 \\
98.58 \\
100.5 \\
102.0 \\
103.3\end{array}$ & $\begin{array}{l}109.4 \\
110.6 \\
111.5 \\
112.2 \\
112.5\end{array}$ & $\begin{array}{l}121.9 \\
122.2 \\
122.1 \\
121.8 \\
121.2\end{array}$ \\
\hline $\begin{array}{l}450 \ldots \\
460 \ldots \\
470 \ldots \\
480 \ldots \\
490 \ldots\end{array}$ & $\begin{array}{l}59.85 \\
63.90 \\
68.10 \\
72.20 \\
76.15\end{array}$ & $\begin{array}{l}62.26 \\
66.31 \\
70.32 \\
74.20 \\
77.93\end{array}$ & $\begin{array}{l}74.00 \\
77.35 \\
80.47 \\
83.42 \\
86.22\end{array}$ & $\begin{array}{l}84.90 \\
87.42 \\
89.71 \\
91.72 \\
93.49\end{array}$ & $\begin{array}{l}94.93 \\
96.51 \\
97.86 \\
98.87 \\
99.70\end{array}$ & $\begin{array}{l}104.1 \\
104.8 \\
105.1 \\
105.5 \\
105.3\end{array}$ & $\begin{array}{l}112.4 \\
112.2 \\
111.7 \\
111.0 \\
110.0\end{array}$ & $\begin{array}{l}120.1 \\
119.0 \\
117.6 \\
116.1 \\
114.3\end{array}$ \\
\hline $\begin{array}{l}500 \ldots \\
510-.- \\
520- \\
530-. \\
540 \ldots\end{array}$ & $\begin{array}{l}80.05 \\
83.70 \\
87.25 \\
90.70 \\
93.90\end{array}$ & $\begin{array}{l}81.63 \\
85.11 \\
88.42 \\
91.55 \\
94.50\end{array}$ & $\begin{array}{l}88.78 \\
91.13 \\
93.36 \\
95.25 \\
97.06\end{array}$ & $\begin{array}{l}95.02 \\
96.41 \\
97.50 \\
98.41 \\
99.07\end{array}$ & $\begin{array}{l}100.4 \\
100.7 \\
100.9 \\
100.9 \\
100.7\end{array}$ & $\begin{array}{l}105.0 \\
104.5 \\
103.9 \\
103.1 \\
102.2\end{array}$ & $\begin{array}{l}109.0 \\
107.7 \\
106.3 \\
104.8 \\
103.4\end{array}$ & $\begin{array}{l}112.6 \\
110.6 \\
108.7 \\
106.5 \\
104.5\end{array}$ \\
\hline $\begin{array}{l}550 \ldots \\
560 \ldots \\
570 \ldots \\
580 \\
590 \\
\end{array}$ & $\begin{array}{l}97.00 \\
100.00 \\
102.6 \\
105.2 \\
107.6\end{array}$ & $\begin{array}{l}97.33 \\
100.00 \\
102.4 \\
104.7 \\
106.8\end{array}$ & $\begin{array}{l}98.58 \\
100.00 \\
101.1 \\
102.2 \\
103.0\end{array}$ & $\begin{array}{l}99.65 \\
100.00 \\
100.2 \\
100.3 \\
100.2\end{array}$ & $\begin{array}{r}100.4 \\
100.00 \\
99.33 \\
98.73 \\
97.89\end{array}$ & $\begin{array}{r}101.1 \\
100.00 \\
98.77 \\
97.51 \\
96.03\end{array}$ & $\begin{array}{c}101.7 \\
100.00 \\
98.20 \\
96.41 \\
94.51\end{array}$ & $\begin{array}{c}102.3 \\
100.00 \\
97.75 \\
95.60 \\
93.28\end{array}$ \\
\hline 600 & $\begin{array}{l}109.8 \\
111.8 \\
113.6 \\
115.3 \\
116.8\end{array}$ & $\begin{array}{l}108.7 \\
110.4 \\
111.9 \\
113.2 \\
114.5\end{array}$ & $\begin{array}{l}103.6 \\
104.1 \\
104.6 \\
104.7 \\
104.8\end{array}$ & $\begin{array}{c}100.1 \\
99.57 \\
99.13 \\
98.50 \\
97.92\end{array}$ & $\begin{array}{l}96.90 \\
95.97 \\
94.89 \\
93.68 \\
92.49\end{array}$ & $\begin{array}{l}94.62 \\
93.09 \\
91.63 \\
90.02 \\
88.40\end{array}$ & $\begin{array}{l}92.58 \\
90.75 \\
88.80 \\
86.94 \\
84.96\end{array}$ & $\begin{array}{l}91.05 \\
88.84 \\
86.73 \\
84.50 \\
82.37\end{array}$ \\
\hline 650 & $\begin{array}{l}118.1 \\
119.2 \\
120.2 \\
121.1 \\
121.8\end{array}$ & $\begin{array}{l}115.5 \\
116.3 \\
117.1 \\
117.7 \\
118.2\end{array}$ & $\begin{array}{l}104.8 \\
104.6 \\
104.3 \\
104.0 \\
103.5\end{array}$ & $\begin{array}{l}97.16 \\
96.24 \\
95.35 \\
94.39 \\
93.44\end{array}$ & $\begin{array}{l}91.26 \\
89.98 \\
88.63 \\
87.24 \\
85.88\end{array}$ & $\begin{array}{l}86.71 \\
85.09 \\
83.43 \\
81.83 \\
80.17\end{array}$ & $\begin{array}{l}83.05 \\
81.20 \\
79.33 \\
77.44 \\
75.59\end{array}$ & $\begin{array}{l}80.21 \\
78.15 \\
76.05 \\
74.04 \\
72.11\end{array}$ \\
\hline $\begin{array}{l}700 \\
710 \\
720\end{array}$ & $\begin{array}{l}122.4 \\
122.8 \\
123.1\end{array}$ & $\begin{array}{l}118.5 \\
118.7 \\
118.7\end{array}$ & $\begin{array}{l}103.0 \\
102.5 \\
101.7\end{array}$ & $\begin{array}{l}92.33 \\
91.24 \\
90.07\end{array}$ & $\begin{array}{l}84.46 \\
82.98 \\
81.54\end{array}$ & $\begin{array}{l}78.47 \\
76.82 \\
75.20\end{array}$ & $\begin{array}{l}73.80 \\
72.07 \\
70.29\end{array}$ & $\begin{array}{l}70.16 \\
68.30 \\
66.43\end{array}$ \\
\hline
\end{tabular}

(See footnote at end of table.) 
TABLE 2.-Spectral energy distribution of a Planckian radiator or black body at various temperatures-Continued

\begin{tabular}{|c|c|c|c|c|c|c|c|c|}
\hline \multirow{2}{*}{$\begin{array}{l}\text { Wave length in } \\
\text { millimicrons }\end{array}$} & \multicolumn{8}{|c|}{ Relative energy distribution ${ }^{1}$ at- } \\
\hline & $8,000^{\circ} \mathrm{K}$. & $9,000^{\circ} \mathrm{K}$. & $10,000^{\circ} \mathrm{K}$. & $12,000^{\circ} \mathrm{K}$. & $14,000^{\circ} \mathrm{K}$. & $16,000^{\circ} \mathrm{K}$ & $18,000^{\circ} \mathrm{K}$. & $20,000^{\circ} \mathrm{K}$. \\
\hline $\begin{array}{l}350-- \\
360- \\
370- \\
380- \\
390-- \\
\end{array}$ & $\begin{array}{l}148.1 \\
148.4 \\
148.2 \\
147.6 \\
146.4\end{array}$ & $\begin{array}{l}180.9 \\
178.5 \\
175.7 \\
172.5 \\
169.0\end{array}$ & $\begin{array}{l}211.5 \\
206.2 \\
200.7 \\
195.0 \\
189.1\end{array}$ & $\begin{array}{l}265.6 \\
254.5 \\
243.6 \\
233.0 \\
222.6\end{array}$ & $\begin{array}{l}310.3 \\
293.6 \\
278.1 \\
263.1 \\
248.8\end{array}$ & $\begin{array}{l}347.0 \\
325.7 \\
305.7 \\
287.0 \\
269.4\end{array}$ & $\begin{array}{l}377.6 \\
352.0 \\
328.2 \\
306.3 \\
286.3\end{array}$ & $\begin{array}{l}403.0 \\
373.7 \\
347.1 \\
322.5 \\
300.0\end{array}$ \\
\hline $\begin{array}{l}400 \ldots \\
410- \\
420 \\
430- \\
440-\end{array}$ & $\begin{array}{l}145.0 \\
143.1 \\
140.9 \\
138.5 \\
136.0\end{array}$ & $\begin{array}{l}165.3 \\
161.2 \\
157.2 \\
152.9 \\
148.6\end{array}$ & $\begin{array}{l}182.9 \\
177.0 \\
170.9 \\
165.1 \\
159.2\end{array}$ & $\begin{array}{l}212.4 \\
202.7 \\
193.6 \\
184.6 \\
176.0\end{array}$ & $\begin{array}{l}235.1 \\
222.5 \\
210.4 \\
199.1 \\
188.4\end{array}$ & $\begin{array}{l}253.4 \\
237.9 \\
224.0 \\
210.5 \\
198.3\end{array}$ & $\begin{array}{l}267.6 \\
250.4 \\
231.3 \\
219.4 \\
20.5 .6\end{array}$ & $\begin{array}{l}278.9 \\
260.0 \\
242.5 \\
226.2 \\
211.3\end{array}$ \\
\hline $\begin{array}{l}470 \\
480 \\
490\end{array}$ & $\begin{array}{l}133.4 \\
130.5 \\
127.5 \\
124.5 \\
121.5\end{array}$ & $\begin{array}{l}144.3 \\
140.0 \\
135.7 \\
131.4 \\
127.2\end{array}$ & $\begin{array}{l}153.4 \\
147.7 \\
142.3 \\
136.8 \\
131.7\end{array}$ & $\begin{array}{l}167.9 \\
160.0 \\
152.7 \\
145.6 \\
138.7\end{array}$ & $\begin{array}{l}178.4 \\
169.0 \\
160.0 \\
151.7 \\
143.7\end{array}$ & $\begin{array}{l}186.6 \\
175.8 \\
165.8 \\
156.3 \\
147.6\end{array}$ & $\begin{array}{l}192.8 \\
181.1 \\
170.1 \\
159.8 \\
150.4\end{array}$ & $\begin{array}{l}197.5 \\
185.0 \\
173.2 \\
162.5 \\
152.5\end{array}$ \\
\hline $\begin{array}{l}500 \ldots \\
510 \ldots \\
520 \ldots \\
530 \\
540 .\end{array}$ & $\begin{array}{l}118.3 \\
115.3 \\
112.1 \\
109.0 \\
106.0\end{array}$ & $\begin{array}{l}123.0 \\
119.0 \\
115.0 \\
111.1 \\
107.2\end{array}$ & $\begin{array}{l}126.7 \\
121.8 \\
117.0 \\
112.5 \\
108.1\end{array}$ & $\begin{array}{l}132.3 \\
126.2 \\
120.4 \\
114.9 \\
109.6\end{array}$ & $\begin{array}{l}136.3 \\
129.3 \\
122.7 \\
116.5 \\
110.7\end{array}$ & $\begin{array}{l}139.3 \\
131.6 \\
124.5 \\
117.8 \\
111.5\end{array}$ & $\begin{array}{l}141.7 \\
133.4 \\
125.8 \\
118.7 \\
112.1\end{array}$ & $\begin{array}{l}143.2 \\
134.6 \\
126.6 \\
119.2 \\
112.3\end{array}$ \\
\hline $\begin{array}{l}550 \\
560 \\
570 \\
580_{-} \\
590_{-}\end{array}$ & $\begin{array}{l}103.0 \\
100.00 \\
97.05 \\
94.14 \\
91.36\end{array}$ & $\begin{array}{c}103.6 \\
100.00 \\
96.53 \\
93.14 \\
89.92\end{array}$ & $\begin{array}{c}104.0 \\
100.00 \\
95.98 \\
92.31 \\
88.75\end{array}$ & $\begin{array}{r}104.7 \\
100.00 \\
95.46 \\
91.19 \\
87.16\end{array}$ & $\begin{array}{r}105.1 \\
100.00 \\
95.10 \\
90.49 \\
86.15\end{array}$ & $\begin{array}{c}105.5 \\
100.00 \\
94.81 \\
90.05 \\
85.46\end{array}$ & $\begin{array}{c}105.8 \\
100.00 \\
94.60 \\
89.55 \\
84.91\end{array}$ & $\begin{array}{c}105.9 \\
100.00 \\
94.37 \\
89.22 \\
84.38\end{array}$ \\
\hline $\begin{array}{l}600 \ldots \ldots \\
610 \ldots- \\
620 \ldots \\
630 \ldots \\
640 \ldots \\
\end{array}$ & $\begin{array}{l}88.50 \\
85.87 \\
83.24 \\
80.68 \\
78.18\end{array}$ & $\begin{array}{l}86.76 \\
83.66 \\
80.71 \\
77.90 \\
75.21\end{array}$ & $\begin{array}{l}85.21 \\
82.02 \\
78.91 \\
75.78 \\
72.93\end{array}$ & $\begin{array}{l}83.34 \\
79.73 \\
76.20 \\
72.97 \\
69.78\end{array}$ & $\begin{array}{l}82.05 \\
78.17 \\
74.51 \\
71.05 \\
67.74\end{array}$ & $\begin{array}{l}81.14 \\
77.16 \\
73.29 \\
69.74 \\
66.44\end{array}$ & $\begin{array}{l}80.42 \\
76.30 \\
72.40 \\
68.82 \\
65.32\end{array}$ & $\begin{array}{l}79.83 \\
75.64 \\
71.67 \\
67.95 \\
64.49\end{array}$ \\
\hline $\begin{array}{l}650 \\
66000 \\
680 \\
690\end{array}$ & $\begin{array}{l}75.73 \\
73.36 \\
71.12 \\
68.83 \\
66.73\end{array}$ & $\begin{array}{l}72.54 \\
69.99 \\
67.55 \\
65.20 \\
62.93\end{array}$ & $\begin{array}{l}70.10 \\
67.51 \\
64.90 \\
62.49 \\
60.12\end{array}$ & $\begin{array}{l}66.83 \\
64.02 \\
61.33 \\
58.77 \\
56.38\end{array}$ & $\begin{array}{l}64.69 \\
61.78 \\
59.01 \\
56.43 \\
53.90\end{array}$ & $\begin{array}{l}63.23 \\
60.26 \\
57.42 \\
54.79 \\
52.28\end{array}$ & $\begin{array}{l}62.09 \\
59.10 \\
56.25 \\
53.61 \\
51.08\end{array}$ & $\begin{array}{l}61.21 \\
58.18 \\
55.29 \\
52.61 \\
50.05\end{array}$ \\
\hline $\begin{array}{l}700 \\
710 \\
720\end{array}$ & $\begin{array}{l}64.68 \\
62.67 \\
60.70\end{array}$ & $\begin{array}{l}60.75 \\
58.65 \\
56.62\end{array}$ & $\begin{array}{l}57.87 \\
55.76 \\
53.70\end{array}$ & $\begin{array}{l}54.09 \\
51.89 \\
49.77\end{array}$ & $\begin{array}{l}51.61 \\
49.35 \\
47.24\end{array}$ & $\begin{array}{l}49.94 \\
47.70 \\
45.55\end{array}$ & $\begin{array}{l}48.66 \\
46.41 \\
44.32\end{array}$ & $\begin{array}{l}47.68 \\
45.40 \\
43.27\end{array}$ \\
\hline
\end{tabular}

$1 C_{2}=14,350 \mu^{\circ}$. All values from $350 \mathrm{~m} \mu$ to $390 \mathrm{~m} \mu$, inclusive, have been computed from Table 1 of B.S. Misc. Pub. No. 56, Frehafer and Snow, 1925; the remaining values, $400 \mathrm{~m} \mu$ to $720 \mathrm{~m} \mu$, have been taken from the tables of M56 or read from the graphs of M56 when not tabulated, except at $2,360^{\circ}$ and $2,848^{\circ} \mathrm{K}$., which came from previous computation in the colorimetry section. Note, howerer, that the tabulated values of M56 are given consistently to four significant figures, whereas values less than 10 derived from the graphs of M56 can be read only to the second decimal. Since further figures were of no practical importance in this investigation, all values less than 10, however derived, were taken only to the second decimal as abulated herein.

The authors of the present paper have used the tables of M56 so far as they were applicable,${ }^{9}$ have read values from the graphs at intermediate temperatures, ${ }^{9}$ and by means of the auxiliary table noted above have extended values of relative energy to $350 \mathrm{~m} \mu$, the region $350 \mathrm{~m} \mu$ to $390 \mathrm{~m} \mu$ being of importance photographically. These values of relative energy are given in Table 2, and serve not only as a record of the actual values used in the present investigation, but as a convenient set of reference tables more extensive than those of M56 from which they were derived.

- Slight qualifications to these statements may be noted in the footnote to Table 2. 
The following method was used to obtain values of relative energy from $350 \mathrm{~m} \mu$ to $390 \mathrm{~m} \mu$. A large-scale plot of Table 1 of M56 over the range applicable was made, plotting values of $\frac{E_{\lambda}}{E_{m}}$ against the products $\lambda \theta$ as therein tabulated. Values of $\lambda \theta$ were then computed for the values of temperature, $\theta$, given in Table 2 and for values of $\lambda$ equal to $350 \mathrm{~m} \mu, 360 \mathrm{~m} \mu, 370 \mathrm{~m} \mu, 380 \mathrm{~m} \mu, 390 \mathrm{~m} \mu, 400 \mathrm{~m} \mu, 410 \mathrm{~m} \mu, 420 \mathrm{~m} \mu, 450 \mathrm{~m} \mu$, and $560 \mathrm{~m} \mu$. For any value of $\theta$, thereupon, values of $\frac{E_{\lambda}}{E_{m}}$ were read from the large-scale plot for the values of $\lambda \theta$ computed, and then tabulated at the respective wave lengths. This gave a series of relative energy values for a given temperature, $\theta$, which were then reduced to 100.00 at $560 \mathrm{~m} \mu$ by means of the proper factor.

Values thus obtained at $400 \mathrm{~m} \mu, 410 \mathrm{~m} \mu, 420 \mathrm{~m} \mu$, and $450 \mathrm{~m} \mu$ were then compared with the values at those wave lengths previously obtained from the tables and graphs of M56. Let $E_{1}$ be the values obtained by the authors, as indicated above, from Table 1 of M56, and let $E_{2}$ be the values taken from Table 2 b of M56 or read from the graphs of M56 which are based directly upon Table 2b. Then $\frac{E_{1}-E_{2}}{E_{2}} \times 100$ represents the percentage deviation of the two sets of energy values. Where the values of $E_{2}$ were taken from the tables of M56, the deviations were nowhere greater than 0.17 per cent; and where values of $E_{2}$ were obtained from the curves of M56, the deviations were nowhere greater than 0.29 per cent. These figures afford an interesting comparison with the accuracy claimed by the authors of M56, viz, 0.15 and 0.33 per cent, respectively, for the tables and graphs. In table 2 of the present paper the values given at $400 \mathrm{~m} \mu$, $410 \mathrm{~m} \mu, 420 \mathrm{~m} \mu$, and $450 \mathrm{~m} \mu$ are those obtained from Table $2 \mathrm{~b}$ and the graphs of M56, not those derived from Table 1 of M56 for comparison purposes.

\section{(c) USE OF HIGH COLOR TEMPERATURES}

It has been demonstrated by means of Priest's rotatory-dispersion colorimetric photometer (30) that the various phases of sunlight and daylight ranging from the yellow of morning and afternoon sun to the blue of a clear sky may be approximately matched in color by light having a Planckian spectral distribution. The colors of the stars may also be described in terms of the color temperature scale. Furthermore, the true subjective white may be found to lie at some place along this high color temperature scale.

It has, therefore, seemed desirable to design filters for duplicating black-body colors, beginning at the color temperatures above which bare Mazda C.lamps can not be operated and extending up to $10,000^{\circ}$ or $20,000^{\circ} \mathrm{K}$., the color of blue sky. The energy distributions referred to in the last section have served as ideals in the design of such filters.

\section{THE ACETYLENE FLAME}

The acetylene flame has been used extensively in photographic sensitometry and a filter has, therefore, been designed (Sec. V, 6) for converting the spectral energy and color of this light to those of mean sunlight. For this purpose the relative spectral energy data of Coblentz (27) have been used. These data were not given regularly at 
every $10 \mathrm{~m} \mu$. They were accordingly plotted and a curve drawn carefully through these experimental values. Values at every $10 \mathrm{~m} \mu$ were read from this curve and then adjusted by an appropriate factor giving 100.00 at $560 \mathrm{~m} \mu$. In Table 3 are given the values of relative energy as thus derived from Coblentz's data, and the same values reduced to 100.00 at $560 \mathrm{~m} \mu$.

The color temperature of the acetylene flame with an E. K. standard burner is commonly taken as $2,360^{\circ} \mathrm{K}$., as determined by Hyde, Forsythe, and Cady (32). The value computed from Coblentz's energy data is, however, $2,413^{\circ} \mathrm{K} .{ }^{10}$ Some preliminary tests of the color temperature of this flame by the authors also gave a value over $2,400^{\circ} \mathrm{K}$. This question is discussed further in Section VIII, 6 .

TABLE 3.- Spectral energy distribution of an acetylene flame

\begin{tabular}{|c|c|c|c|c|c|}
\hline \multirow{2}{*}{ Wave length in millimicrons } & \multicolumn{2}{|c|}{$\begin{array}{l}\text { Relative encrgy } \\
\text { distribution }\end{array}$} & \multirow{2}{*}{ Wave length in millimicrons } & \multicolumn{2}{|c|}{$\begin{array}{l}\text { Relative energy } \\
\text { distribution }\end{array}$} \\
\hline & $\begin{array}{l}\text { Co- } \\
\text { blentz's } \\
\text { data }\end{array}$ & $\begin{array}{l}\text { Reduced } \\
\text { to } 100.00 \\
\text { at } 560 \mathrm{~m} \mu\end{array}$ & & $\begin{array}{l}\text { Co- } \\
\text { blentz's } \\
\text { data }\end{array}$ & $\begin{array}{l}\text { Reduced } \\
\text { to } 100.00 \\
\text { at } 560 \mathrm{~m} \mu\end{array}$ \\
\hline $\begin{array}{l}380 \\
390\end{array}$ & $\begin{array}{l}3.9 \\
4.4\end{array}$ & $\begin{array}{r}9.09 \\
10.26\end{array}$ & $\begin{array}{l}600 \\
610^{-}-\end{array}$ & $\begin{array}{r}162.5 \\
67.8\end{array}$ & $\begin{array}{l}145.69 \\
158.04\end{array}$ \\
\hline $\begin{array}{l}400 \\
410 \\
420\end{array}$ & $\begin{array}{r}15.0 \\
5.7 \\
6.5\end{array}$ & $\begin{array}{l}11.66 \\
13.29 \\
15.15\end{array}$ & $630 \ldots$ & $\begin{array}{r}173.3 \\
79.1 \\
185.0\end{array}$ & $\begin{array}{l}170.86 \\
184.38 \\
198.14\end{array}$ \\
\hline 4300 & $\begin{array}{r}7.4 \\
18.5\end{array}$ & $\begin{array}{l}17.25 \\
19.81\end{array}$ & & $\begin{array}{l}191.2 \\
197.6\end{array}$ & $\begin{array}{l}212.59 \\
227.51\end{array}$ \\
\hline $\begin{array}{l}450 \\
460 \\
470\end{array}$ & $\begin{array}{rl}1 & 10.0 \\
1 & 11.8 \\
13.8\end{array}$ & $\begin{array}{l}23.31 \\
27.51 \\
32.17\end{array}$ & $\begin{array}{l}670 \ldots \\
650 \ldots \\
690-\cdots\end{array}$ & $\begin{aligned} 104.2 \\
1110.9 \\
117.4\end{aligned}$ & $\begin{array}{l}242.89 \\
258.51 \\
273.66\end{array}$ \\
\hline 480 & $\begin{array}{l}16.2 \\
18.5\end{array}$ & $\begin{array}{l}37.76 \\
43.12\end{array}$ & & ${ }^{1} 124.1$ & 289. 28 \\
\hline $\begin{array}{l}500 \\
510 \\
530\end{array}$ & $\begin{array}{r}120.9 \\
24.1 \\
127.5 \\
31.0 \\
134.6\end{array}$ & $\begin{array}{l}48.72 \\
56.18 \\
64.10 \\
72.26 \\
80.65\end{array}$ & $\begin{array}{l}720 \ldots \\
425 \\
475 \\
575 \\
625\end{array}$ & $\begin{array}{rl}1 & 137.5 \\
1 & 7.0 \\
1 & 15.0 \\
1 & 29.2 \\
1 & 49.8 \\
1 & 76.1\end{array}$ & 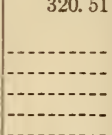 \\
\hline 5500 & $\begin{array}{r}138.9 \\
142.9 \\
47.5 \\
152.2 \\
57.3\end{array}$ & $\begin{array}{r}90.68 \\
100.00 \\
110.72 \\
121.68 \\
133.57\end{array}$ & $675 \ldots$ & 1107.5 & $x^{2}$ \\
\hline
\end{tabular}

1 These values are taken from Table 1 of B. S. Sci. Paper No. 362, W. W. Coblentz, "Distribution of Energy in the spectrum of an Acetylene Flame," 1920. The remaining values were derived by the authors from a large-scale plot of Coblentz's data.

\section{COMPONENT MATERIALS OF FILTERS}

The several desirable characteristics of white-light filters have been indicated in Section II, 2, and it was there noted that certain solutions of inorganic salts apparently had none of the serious faults to which the other materials were subject and which would prevent their adoption and use as general working standards. Obviously, filters for converting lower to higher color temperatures should have little absorption in the violet with increasing absorption toward the red end of the spectrum. Such filters will, of course, have a bluish color. Several blue solutions are available, such as aqueous nickel sulphate and ammonia, aqueous copper sulphate and ammonia, and

10 As computed by Davis' method, see footnote to Table 13. 
others, but they only crudely approximate the desired spectral absorption. An important step toward the solution of the problem was made by Pfund (23) in the discovery that the spectral deficiencies in the absorption of an ammoniacal copper-sulphate solution could be corrected to a large extent by an aqueous solution of cobalt sulphate and copper sulphate. Considerable interesting information regarding the characteristics of various solutions and glass cells tested for photometric use is given in papers $(33,34)$ by Ives and Kingsbury.

\section{CHOICE OF MATERIALS}

\section{(a) AQUEOUS AMMONIA SOLUTION OF COPPER SULPHATE}

At the start of the investigation considerable time was spent designing filters, by trial and error and by computation from spectrophotometric data, with the component materials used in Pfund's filter. It was found that the transmittancy curve of the ammoniacal coppersulphate solution changed considerably with the ammonia content for a given concentration of copper sulphate. There were shifts in the wave lengths of the maximum and minimum transmittancies with changes in ammonia content, accompanied by increased values of transmittancy at some wave lengths and decreased values at others. From the standpoint of the resulting energy distribution a content of about $100 \mathrm{cc}$ of ammonia water $\left(28\right.$ per cent $\left.\mathrm{NH}_{3}\right)$ per liter of solution was determined as the most suitable.

When the copper sulphate is varied, keeping the ammonia-water content constant at $100 \mathrm{cc}$ per liter of solution, Beer's law was apparently obeyed over a range from 2 to $5 \mathrm{~g}$ of copper sulphate, but failed to some extent at $1 \mathrm{~g}$. This question of obedience to Beer's law is, of course, important when a series of filters is designed by computation from standard spectrophotometric data obtained at some one concentration, if it has been chosen to vary concentration rather than thickness. (The data on Beer's law were rather meager, and the measurements were not continued because of the decision to use pyridine instead of ammonia.)

Ammonia water has two well-known characteristics which tend to make its use for filters unsatisfactory, and which led to the search for a substitute. These undesirable features are: (1) Its corrosive action on glass. It attacks the glass of cells and bottles. In addition to this undesirable property, particularly with respect to its effect on the optical glass plates of the filter cells, it was thought that this action might be accompanied by changes in the absorption of the solution. (2) Its tendency to lose ammonia. Ammonia water must be tested for strength before using. Furthermore, if the container is inadequately stoppered or sealed, there is danger of ammonia gas escaping from the solution, with consequent change in absorption as noted above. Ives and Kingsbury (33, p. 799) speak of the change of color caused by the "unpreventable evaporation" of ammonia. (b) AQUEOUS PYRIDINE SOLUTON OF COPPER SULPHATE WITH MANNITE-

As a substitute for ammonia, pyridine $\left(\mathrm{C}_{5} \mathrm{H}_{5} \mathrm{~N}\right)$ was tried. This gives a blue solution with copper sulphate resembling that obtained with ammonia. Spectrophotometric tests of the solutions showed 
absorption changes with variation of pyridine content, as was the case with ammonia.

However, a very serious defect of the copper-sulphate-pyridine solution soon developed. It was found to be rather unstable. This instability varied considerably with the pyridine content, the solutions being most stable with a large proportion (20 per cent total volume) of pyridine and poorest with small proportions. The best proportion from the standpoint of the final energy distribution was judged to be about $30 \mathrm{cc}$ of pyridine per liter, but with this amount the solution showed signs of precipitation after standing a few days in very warm weather ( $35^{\circ}$ to $40^{\circ} \mathrm{C}$.).

Nevertheless, these preliminary tests showed the use of pyridine to be so promising that some method was sought whereby the coppersulphate-pyridine solution could be made stable. During a series of experiments having this end in view, it was found that the addition of glycerine to the solution retarded the precipitation enormously. When precipitation with glycerine present did start, however, a scum appeared on the surface of the solution and on the sides of the vessel. (In these experiments just barely enough pyridine was used to convert the copper sulphate to the soluble copper-pyridine compound so that precipitation started very shortly after the mixture was made. The temperature has a very marked influence on the rate of precipitation.) This increased stability with glycerine was so striking that a search was made for other materials of similar structure to glycerin, with the result that mannite ( $d$-manitol) was suggested. This material proved to be very satisfactory, and solutions over four years old show no precipitation. A very slight change in absorption does take place upon long standing, however, and this feature is discussed in Section VII, 3. The quantity of mannite used is an amount equal to the weight of copper sulphate used. Apparently no change in the transmittancy of the copper-sulphate-pyridine solution is caused by the addition of mannite.

The copper-sulphate-pyridine-mannite solutions showed the same changes in absorption with changes in the pyridine content as were exhibited by the simple copper-sulphate-pyridine solutions, analogous to the changes in the ammonia solutions as already noted. The data illustrated in Figure 8 show the effects of varying the pyridine content over the range from 10 to $100 \mathrm{cc}$ per liter of solution with a constant quantity (3 g) of copper sulphate. Further investigation (Sec. VIII, 3 ) confirmed the previous conclusion that $30 \mathrm{cc}$ of pyridine per liter gave a more suitable type of absorption than larger or smaller proportions. An aqueous solution containing, unless otherwise stated, $30 \mathrm{cc}$ of pyridine per liter and having varying amounts of copper sulphate (and mannite) has been designated as "solution A" and is usually thus referred to throughout the rest of the paper.

Having determined the most desirable amount of pyridine to use, a study of Beer's law was made over the range of concentrations of copper sulphate (and mannite) necessary for the filters. A slight failure was found which is described in detail in Section VII, 6. The method of making the Beer's law corrections in the computations is illustrated in Section V, 3 and in Table 4.

The comparative advantages and disadvantages in the use of aqueous ammonia or pyridine solutions of copper sulphate may be summarized as follows: 
1. In the most suitable proportions as determined spectrophotometrically, $30 \mathrm{cc}$ of pyridine and $100 \mathrm{cc}$ of ammonia per liter, the ammonia solutions will attack glass while the pyridine solutions will not.

2. Ammonia gas readily escapes from ammonia water. This difficulty is not encountered with pyridine, the boiling point of which

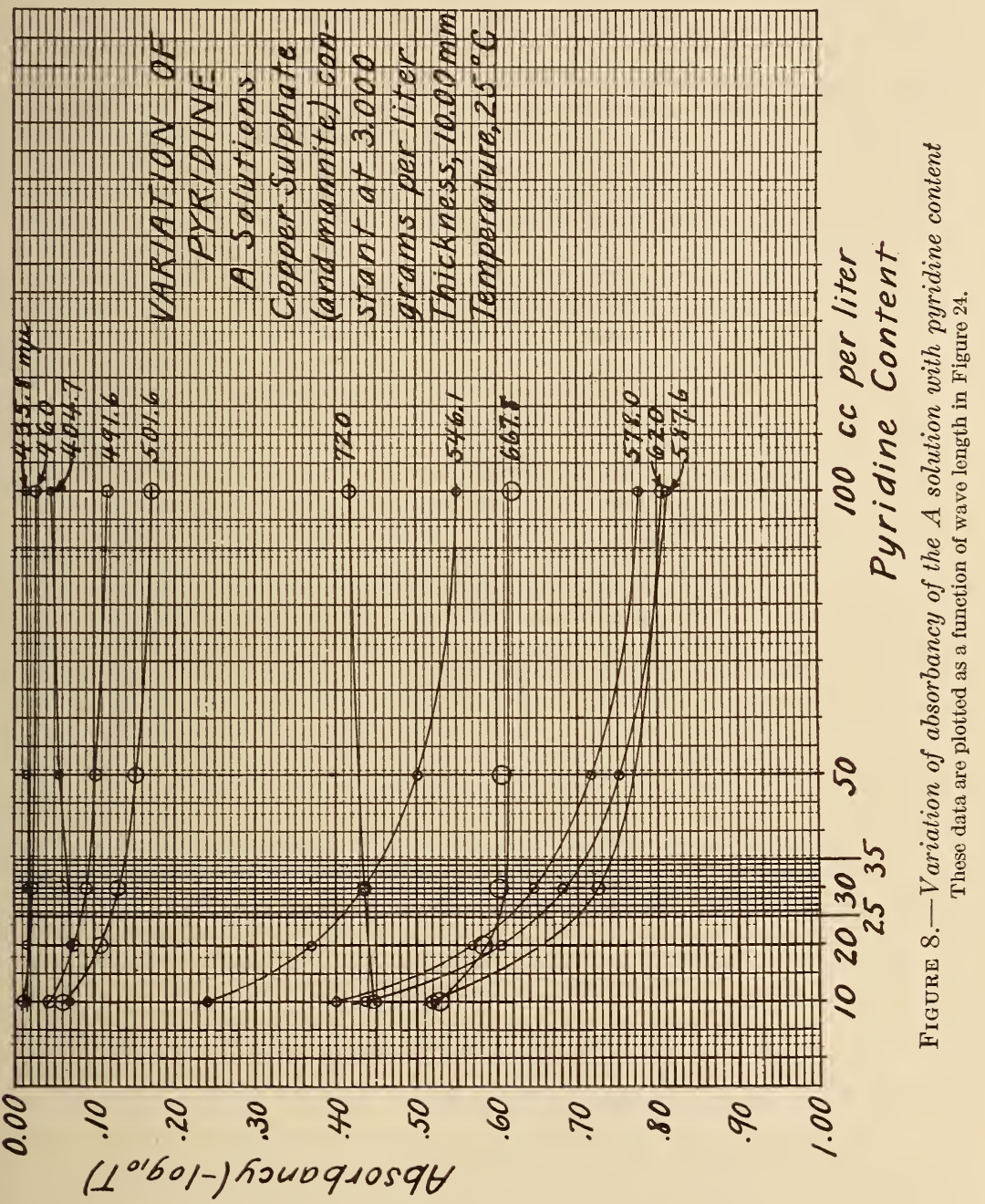

is $115.5^{\circ} \mathrm{C}$. In view of the change in absorption that takes place with variation in either the ammonia or pyridine content this advantage of the pyridine over the ammonia is important.

3. At the most favorable content of either ammonia or pyridine there is no particular advantage of one over the other so far as spectral transmission is concerned, except that in the violet and ultra-violet the ammonia solutions have the higher transmittancy. If filters were prepared using ammonia instead of pyridine, the agreement between 
the computed and ideal energy distributions would be slightly better at these short wave lengths in the majority of cases than was obtained with the pyridine filters as herein described.

4. So far as the evidence goes, the obedience to Beer's law is closer for the ammonia solutions than for the pyridine solutions. This might have saved time and labor in the measurements and computations, but would not result in any greater accuracy in the final filters.

5. By spectrophotometric test, the ammonia solutions, if evaporation is prevented, appear to be somewhat more permanent than the pyridine solutions. Here, as elsewhere, the data for the ammonia solutions is less extensive than for the pyridine solutions, because of the decision to use pyridine in preference to ammonia. Whether the ammonia solutions would remain as permanent under actual working conditions is questionable.

It is believed the importance of the first two points noted above, wherein the pyridine solutions are superior to ammonia solutions, is sufficiently great to outweigh the other points wherein the ammonia solutions seem superior. Although the relative permanence could not be known at the time a decision had to be made, the authors feel justified in their search for and use of pyridine, in preference to ammonia with copper sulphate for securing the principal (blue) component of the filters.

(c) AQUEOUS ACIDIFIED SOLUTION OF COPPER SULPHATE-SOLUTION $B_{1}$

With either solution A or the copper-sulphate-ammonia solution the resulting energy distributions obtained with the most favorable concentrations will show a considerable exeess in the blue-green and far red, and it has already been noted that Pfund found that a satisfactory correcting solution could be obtained from a mixture of copper and cobalt sulphates in aqueous solution.

Copper sulphate $\left(\mathrm{CuSO}_{4} .5 \mathrm{H}_{2} \mathrm{O}\right)$ is a stable compound, readily obtained in relatively pure form. Aqueous solutions containing 10 cc of sulphuric acid showed no failure of Beer's law over a range of concentrations from 5 to $40 \mathrm{~g}$ per liter. The standard medium concentration used for the principal spectrophotometric measurements was $20 \mathrm{~g}$ per liter. While the sulphuric acid, which is a part of solutions $B_{1}, B_{2}$, and $B$, does not cause any change in absorption it serves the useful purposes of clarifying the solutions and preventing the formation of basic copper compounds. An aqueous solution containing $10 \mathrm{cc}$ of sulphuric acid (specific gravity 1.84) per liter of solution and having varying amounts of copper sulphate will be designated as "solution $\mathrm{B}_{1}$."

\section{(d) AQUEOUS ACIDIFIED SOLUTION OF COBALT SULPHATE}

Extensive spectrophotometric data were taken with cobalt sulphate $\left(\mathrm{CoSO}_{4} .7 \mathrm{H}_{2} \mathrm{O}\right)$. The standard concentration, chosen to be in approximately the middle of the desired range, was $10 \mathrm{~g}$ of cobalt sulphate per liter of solution, containing also $10 \mathrm{cc}$ of concentrated sulphuric acid. It was found, however, that the cobalt sulphate had lost some of its water of crystallization and that the standard solution did not, therefore, contain exactly $10 \mathrm{~g}$ of $\mathrm{CoSO}_{4} \cdot 7 \mathrm{H}_{2} \mathrm{O}$. Chemical analysis of this solution showed that it had a concentration equivalent to $10.3 \mathrm{~g}$ of $\mathrm{CoSO}_{4} .7 \mathrm{H}_{2} \mathrm{O}$. 


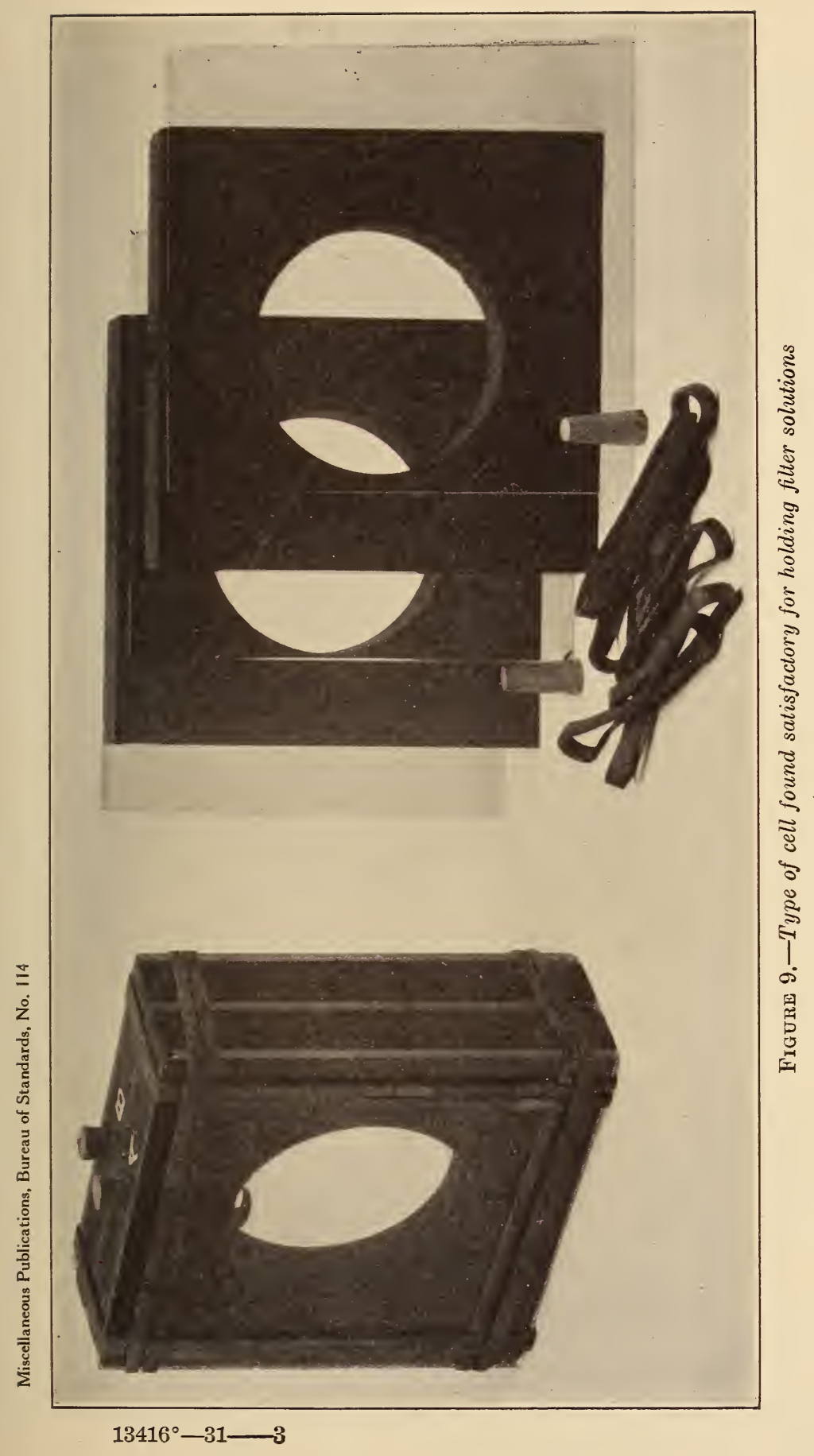




(e) AQUEOUS ACIDIFIED SOLUTION OF COBALT AMMONIUM SULPHATE-
SOLUTION $\mathrm{B}_{3}$

To avoid the uncertainty which would thus be present in the use of cobalt sulphate due to the uncertainty of the water content, the double salt, cobalt ammonium sulphate $\left(\mathrm{CoSO}_{4}\left(\mathrm{NH}_{4}\right)_{2} \mathrm{SO}_{4} \cdot 6 \mathrm{H}_{2} \mathrm{O}\right)$, was suggested. This material was also used in the preparation of photometric filters by Ives and Kingsbury (33) for the same reason.

Spectrophotometric measurements proved the practical equivalence of solutions containing $14.481 \mathrm{~g}$ of cobalt ammonium sulphate and the standardized solution containing $10.3 \mathrm{~g}$ of cobalt sulphate, both alone and in mixture with copper sulphate (See Secs. VII, 2 and VII, $3)$. Beer's law is obeyed in both cases over the range of concentrations used. An aqueous solution containing $10 \mathrm{cc}$ of sulphuric acid per liter and having varying amounts of cobalt ammonium sulphate will be referred to as "solution $\mathrm{B}_{2}$."

(f) MIXTURE OF SOLUTIONS $B_{1}$ AND $B_{2}$-SOLUTION B

It is, of course, desirable to mix the acidified cobalt ammonium sulphate and copper sulphate solutions, as this reduces the number of filter compartments from three to two. Tests on the effect of mixing these two ingredients to form a single solution showed, as expected, that no reaction took place, and that the observed spectral transmittancies agreed perfectly with computed values based on the two standard concentrations. An aqueous solution containing copper sulphate and cobalt ammonium sulphate in varying amounts, together with $10 \mathrm{cc}$ of sulphuric acid per liter is referred to throughout the rest of the paper as "solution B."

\section{(g) CELL FOR HOLDING FILTER SOLUTIONS}

The A and B solutions are contained in a 2-compartment cell, such, for example, as is illustrated in Figure $9 .{ }^{11}$ The essential specification of this cell is that it consist of three borosilicate crown glass plates (each $2.5 \mathrm{~mm}$ thick, refractive index, $D$ line, $=1.51$ ), separated by two glass frames, each $10.00 \mathrm{~mm}$ thick, for containing the respective $\mathrm{A}$ and $\mathrm{B}$ solutions. Borosilicate crown glass was selected for the windows because it is the hardest and most transparent of the optical glasses and probably the most resistant to chemical action.

\section{(h) DEFINITION OF DAVIS-GIBSON FILTERS}

Summarizing the selection of materials, a Davis-Gibson filter may be defined as a 2-compartment cell with three borosilicate crown glass windows, the two compartments being filled, respectively, with solutions $\mathrm{A}$ and $\mathrm{B}$, having compositions as specified below.

Solution A

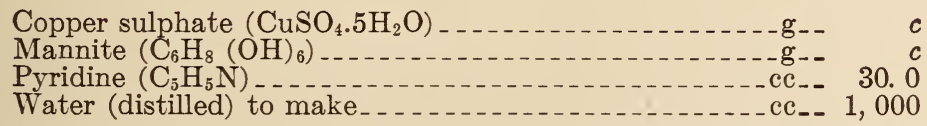

The value of $c$, the weight in grams of copper sulphate (and mannite) per liter of solution, varies with the purpose of the filter, as illustrated in the various charts and tables. When $c$ has the value of $3.000 \mathrm{~g}$

11 This design is similar to that used by Ives and Kingsbury (33). 
(the concentration at which the principal spectrophotometric determinations were made) the solution is referred to as solution $\mathrm{A}^{\prime}$.

Solution B

Copper sulphate $\left(\mathrm{CuSO}_{4} .5 \mathrm{H}_{2} \mathrm{O}\right)$

Sulphuric acid (specific gravity, 1.84)

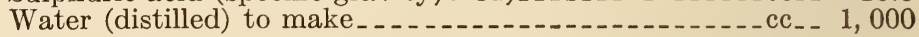

The values of $c_{1}$ and $c_{2}$ depend, again, on the purpose of the filter. When $c_{1}=20.000 \mathrm{~g}$ and $c_{2}=14.481 \mathrm{~g}$, the mixture is referred to as solution $\mathrm{B}^{\prime}$. Separate solutions of copper sulphate and cobalt ammonium sulphate having the weights just given, and containing $10 \mathrm{cc}$ each of sulphuric acid per liter, are referred to, respectively, as solution $\mathrm{B}_{1}{ }^{\prime}$ and solution $\mathrm{B}_{2}{ }^{\prime}$. Extensive spectrophotometric measurements were made on solutions $\mathrm{B}^{\prime}, \mathrm{B}_{1}{ }^{\prime}$, and $\mathrm{B}_{2}{ }^{\prime}$.

\section{PURITY OF CHEMICALS USED}

It was decided early in the investigation to use a grade of chemicals known as "C. P.," because such chemicals are readily available. The term "C. P.", although originally intended to mean "chemically pure," is not at present generally used to designate the purest material available on the market. The terms "analytical reagent quality" or "reagent quality" are often used to designate a higher grade. "C. P." chemicals are, however, superior to "technical" or "commercial" grades. The impurities present in different lots of a given chemical of the "C. P." grade are generally of the same nature, but may differ in amount. It was believed to be the better plan to include the effects of these impurities in the spectrophotometric data, provided such effects were small or negligible, rather than to use specially purified chemicals which would not be generally obtainable. Our experience throughout the investigation has confirmed this opinion. The nature and extent of the most important impurities are indicated below, and their spectrophotometric effects are discussed and illustrated in Section VII.

The analyses given in this section serve to define the materials used in deriving the standard data given in the paper. Questions of reproducibility are discussed further in Section VII, 8. Certain precautions to use in the selection of the materials are considered in Section IX on the preparation of the filters.

To prevent possible contamination from cork stoppers, glass-stoppered bottles were used to hold all solutions.

(a) COPPER SULPHATE

This well-known chemical $\left(\mathrm{CuSO}_{4} .5 \mathrm{H}_{2} \mathrm{O}\right)$, is readily obtainable in high purity. The copper sulphate used in deriving the standard data for the filters was of C. P. quality obtained from Mallinckrodt Chemical Works, St. Louis, Mo. Chemical analysis gave the following impurities (memorandum, March 25, 1926, from chemistry division): 
Per cent

Water insoluble material _...

Iron and aluminum (as $\mathrm{R}_{2} \mathrm{O}_{3}$ ) 007

Zinc (as Zn)

Calcium _. 000

Nickel (as Ni)

Magnesium and alkali salts $\ldots . \ldots 4$

These small quantities of impurities have no practical effect on the spectral transmission of the filters.

The pentahydrate of copper sulphate is ordinarily considered as a stable salt, and for many purposes this is true. It should be noted, however, that the water of crystallization is subject to minor changes under ordinary conditions of keeping. The crystals tend to follow atmospheric changes, gaining or losing water depending on the variation of the aqueous vapor pressure of the air. It may also happen that the salt is not fully air dried, following crystallization before bottling, in which case a given weight of the copper sulphate will contain less than the theoretical copper content. These variations are usually small, seldom amounting to more than \pm 1 per cent, because of the tenacity with which copper sulphate clings to its water of crystallization. The following chemical analysis (Chem. Lab. No. 551/31079-84, January 3, 1929) made later on the same stock as analyzed above for impurities, illustrates this point:

\begin{tabular}{l|r|r}
\hline & $\begin{array}{r}\text { Copper } \\
\text { content }\end{array}$ & $\begin{array}{r}\text { Percentage } \\
\text { of theo- } \\
\text { retical }\end{array}$ \\
\hline Opened bottle from which sample had been taken over a period of more than & Per cent \\
6 months.70 & 25.24 & 100.9 \\
99.1 \\
\hline
\end{tabular}

However, copper sulphate which has been kept for long periods of time, particularly in very dry atmosphere, may lose a larger percentage of its water content. When such a change has taken place to a considerable extent, a whitish powder $\left(\mathrm{CuSO}_{4} \cdot 3 \mathrm{H}_{2} \mathrm{O}\right)$ will be localized on or may cover the surface of the crystals. Such material should not be used in preparing light-filter solutions. It may, of course, be made satisfactory for this purpose by recrystallizing or by rinsing with distilled water and drying to equilibrium.

This uncertainty in the copper content of copper sulphate, amounting, in general, to perhaps \pm 1 per cent of the theoretical content, is apparently of much more importance in the use of the filters than is that resulting from any impurities which are likely to be present. It is, however, of practical importance only in the case of the $\mathrm{A}$ solution. (The magnitude of a 1 per cent variation in the copper content of the $\mathrm{A}$ and $\mathrm{B}$ solutions, both as regards the spectral absorbancy of the solutions and the color of the filters, is apparent from Table 4 and fig. 30.)

The results of the determination of the copper content (Chem. Lab. No. 551/31079-84, above), made on the same lot of copper sulphate as had been used in preparing the standard solutions, rendered somewhat uncertain the exact copper content of solutions for which the standard spectrophotometric data given in Tables 4 and 5 should apply. Accordingly, analyses were made of the $\mathrm{A}^{\prime}$, 
$\mathrm{B}_{1}{ }^{\prime}$, and $\mathrm{B}^{\prime}$ solutions which had been given the most weight in adopting the standard data. The following results were obtained (Chem. Lab. Nos. 551/31079-84, January 3, 1929, and 551/31429-32, January 2, 1929):

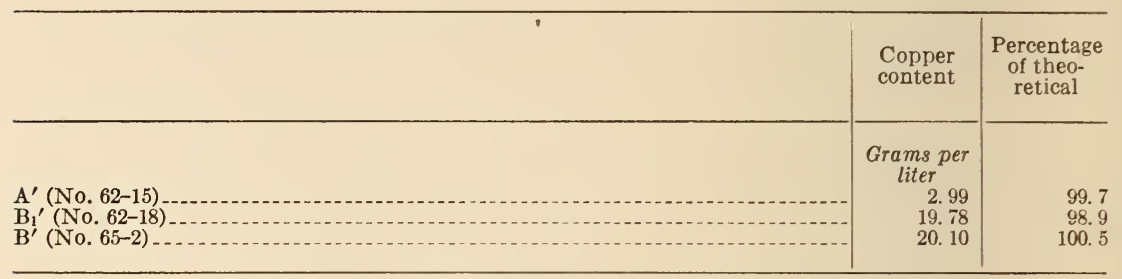

The value 99.7 per cent, falling between the limits obtained on the salt, may be taken as the copper content for which the data of Table 4, solution $\mathrm{A}^{\prime}$, apply, as stated in the footnote to that table.

Solutions $\mathrm{B}_{1}^{\prime}$ (No.62-18) and $\mathrm{B}^{\prime}$ (No. 65-2) were both supposed to have $20.000 \mathrm{~g}$ of copper sulphate per liter. It is shown later on (Sec. VII, 2, $(e)$ and Table 21) that, at $667.8 \mathrm{~m} \mu$ in the red where the copper sulphate absorbs strongly, there was a good check in the absorbancy of the two solutions, allowing for the small absorbancy of the cobalt ammonium sulphate in solution $\mathrm{B}^{\prime}$. This check makes it impossible to choose either of the above analyses in preference to the other; and their mean value of 99.7 per cent (the mean of 98.9 and 100.5 , this being the same value as obtained with the $\mathrm{A}^{\prime}$ solution, No. 62-15) may be taken as the copper content for which the data of Table 5, Solution $\mathrm{B}_{1}{ }^{\prime}$, apply.

\section{(b) COBALT AMMONIUM SULPHATE}

This is a double salt $\left(\mathrm{CoSO}_{4}\left(\mathrm{NH}_{4}\right)_{2} \mathrm{SO}_{4} \cdot 6 \mathrm{H}_{2} \mathrm{O}\right)$ of cobalt sulphate and ammonium sulphate. Nickel is practically always present in the salts of cobalt and it is extremely difficult to remove completely. Nickel sulphate has absorption bands in the violet and far red and is, therefore, very undesirable to have present in any considerable quantity. Because of the cost and difficulty of obtaining cobalt ammonium sulphate free from nickel, which would make it prohibitive for general use in the filters, we chose as a standard a nickel content of 0.075 per cent (ratio of nickel to cobalt $=1: 200$ ). At this proportion the absorption of light due to nickel is practically negligible, but, such as it is, is included in the spectrophotometric data. A ratio of nickel to cobalt not exceeding $1: 100$ is satisfactory for use in the filters. The cobalt ammonium sulphate used in this work was prepared by crystallization from cobalt sulphate and ammonium sulphate. The following extracts from Doctor Wichers's memorandum (chemistry division, March 17, 1927) on tests of these salts will be of interest:

All samples of cobalt sulphate and cobalt ammonium sulphate tested were found to contain nickel. Two samples of cobalt sulphate made by American manufacturers were found to have 0.10 per cent and 0.09 per cent $\mathrm{Ni}$, respectively. This is a ratio of $\mathrm{Ni}$ to Co of about 1:200. A sample of cobalt ammonium sulphate of foreign make held 1.37 per cent $\mathrm{Ni}$ (ratio of $\mathrm{Ni}$ to Co of 1:11). A sample of American-made cobalt ammonium sulphate held 0.20 per cent nickel. These results indicate that nickel may be present in excessive amounts in these salts. Experience shows also that the amount of nickel indicated in the analysis on the label is often in error. 
There seems to be no reason why a sample of cobalt ammonium sulphate can not be made as free of nickel (ratio of $\mathrm{Ni}$ to $\mathrm{Co}$ ) as the corresponding cobalt sulphate. The sample of cobalt ammonium sulphate made from the cobalt sulphate containing 0.10 per cent $\mathrm{Ni}$ had a nickel content of about 0.05 per cent Ni. The ratio of nickel to cobalt here is $1: 300$. The nickel was determined in a sample that had been twice crystallized by you and twice recrystallized in this laboratory. This indicates that a salt contaminated with nickel can not be easily improved by successive recrystallizations as the double sulphate.

Cobalt ammonium sulphate crystallizes as $\mathrm{CoSO}_{4} \cdot\left(\mathrm{NH}_{4}\right)_{2} \mathrm{SO}_{4} \cdot 6 \mathrm{H}_{2} \mathrm{O}$ and is stable under ordinary atmospheric conditions. Exposed in a balance case for a period of two months it showed practically no change in weight. As was to be expected, the weight changed slightly with changes in humidity. Weights taken at different times and under different conditions covered a maximum range of $0.0016 \mathrm{~g}$ on a $7.5 \mathrm{~g}$ sample. The final weight was $0.0004 \mathrm{~g}$ less than the initial.

The theoretical cobalt content in cobalt ammonium sulphate is 14.91 per cent. The cobalt content of the foreign sample was 14.58 per cent; that supplied by an American maker was 14.86 per cent, while the material made by you held 14.60 per cent cobalt. In every case the cobalt is determined by electroly sis so that the figure reported is really the combined cobalt and nickel content. Your sample was recrystallized twice in this laboratory to see if a salt with the theoretical cobalt content could be easily produced. The crystals after being separated from the mother liquor were air dried. Upon analysis they were found to contain the theoretical cobalt content. The values found in two determinations were 14.92 and 14.88 per cent Co.

The following is the method regularly used in the chemical laboratories of the National Bureau of Standards for determinations of the nickel content of cobalt ammonium sulphate (memorandum of January 6, 1928):

Dissolve $1.00 \mathrm{~g}$ of cobalt ammonium sulphate in $300 \mathrm{cc}$ of water. Add $1 \mathrm{~g}$ of tartaric acid and heat the solution to about $80^{\circ} \mathrm{C}$. Then add $100 \mathrm{cc}$ of a 1 per cent alcoholic solution of dimethylglyoxime, and ammonium hydroxide solution until the solution is distinctly alkaline to litmus paper (an excess is to be avoided). Cover the beaker and place on the steam bath for 3 hours and then keep in a warm place (about $40^{\circ}$ C.) for 36 to 48 hours longer. Filter off the precipitate. If little or no precipitate formed allow the filtrate to stand an additional 24 hours to be sure that all the nickel has been precipitated. Add any precipitate which forms to the first precipitate. Dissolve the combined precipitates in $10 \mathrm{cc}$ of hot 1:1 nitric and dilute to $100 \mathrm{cc}$. Heat to about $80^{\circ} \mathrm{C}$. Then add $10 \mathrm{cc}$ of dimethylglyoxime solution and ammonium hydroxide solution until the solution is alkaline to litmus paper, but avoiding an excess. Digest on the steam bath to coagulate the precipitate and filter through a tared, asbestos-covered Gooch crucible. Wash the precipitate thoroughly with hot water and dry at $110^{\circ}$ to $120^{\circ} \mathrm{C}$. for 45 minutes. Multiply the weight of the precipitate by 0.2031 to get the weight of nickel $(\mathrm{Ni})$.

It was stated in Section IV, $1,(d)$ that the cobalt-sulphate solution (No. 62-17) was found by chemical analysis to have $10.3 \mathrm{~g}$ of $\mathrm{CoSO}_{4} \cdot 7 \mathrm{H}_{2} \mathrm{O}$ instead of the $10.000 \mathrm{~g}$ which it was supposed to have. This value was the mean of three analyses made by the chemistry division of the bureau, the individual values being as follows: (1) 10.30 $\mathrm{g}$ per liter, November 19, 1926; (2) $10.39 \mathrm{~g}$ per liter, December 7 , 1926; (3) $10.25 \mathrm{~g}$ per liter, December 9, 1926. The second determination was possibly somewhat too high and less accurate than the other two. At any rate the value of $10.3 \mathrm{~g}$ of cobalt sulphate per liter (equivalent to $14.481 \mathrm{~g}$ of cobalt ammonium sulphate per liter) may be accepted as accurate to a fraction of 1 per cent, and it is this value for which the standard spectrophotometric data of Table 6 apply. 


\section{(c) PYRIDINE}

This is a stable colorless liquid organic compound $\left(\mathrm{C}_{5} \mathrm{H}_{5} \mathrm{~N}\right)$. It has a strong unpleasant odor which gives one the false impression of high volatility. Its boiling point is $115.5^{\circ} \mathrm{C}$. at $760 \mathrm{~mm}$; its specific gravity is $0.979 \pm 0.001$ at $25^{\circ} \mathrm{C}$. The change in specific gravity is 0.001 per ${ }^{\circ} \mathrm{C}$. The pyridine used throughout the present investigation was J. T. Baker Chemical Co.'s C. P. grade.

Pyridine, like most organic compounds, is very difficult to obtain in a pure state. The material which is available commercially in the C. P. grade always contains a small quantity of the higher homologues, the principal one being $\alpha$-picoline. A small amount of water is also usually present. Complete chemical analysis was not made, because a satisfactory procedure to accomplish this result is not available. Since $\alpha$-picoline is considered to be the major impurity likely to be present in pyridine, and because of the difficulty of separating the higher homologues, we have expressed the total effect of these impurities in terms of the equivalent $\alpha$-picoline. Samples of commercial pyridine and $\alpha$-picoline were purified both by fractional distillation and fractional crystallization ${ }^{12}$ of the mercuric chloride compounds of the hydrochlorides, and A solutions prepared containing various amounts of the picoline. The spectrophotometric analysis of these solutions is described in Section VII, $9(b)$. The amount of picoline present in our standard pyridine was shown by the spectrophotometric analysis to be 2.4 per cent by weight. This analysis, combined with titration tests and specific gravity determinations gave 1.2 per cent water and 96.4 per cent pyridine, by weight.

Pyridine is ordinarily tested for strength by titration methods (as described below), and values thus obtained show the true percentage of pyridine only in the absence of the higher homologues or other impurities which also react with the sulphuric acid. With the presence of the higher homologues the combined strength, in terms of pyridine, is obtained.

Our standard pyridine, as analyzed above and as used in deriving the standard spectrophotometric data of Table 4, was thus titrated for strength with half normal sulphuric acid, using methyl orange for an indicator. This work, based on a series of runs by two observers gave a value of 98.4 per cent, which is equivalent to the analysis given above in terms of pyridine, picoline, and water. Since the end point is not particularly sharp, the following procedure was followed:

The $\mathrm{pH}$ value of the end point $(3.2 \pm 0.1)$ was determined by electrometric titration with the hydrogen electrode. In the colorimetric titrations a buffered solution, $\mathrm{pH} 3.2$, was used as a comparison standard for the end-point color. Making use of this end point a sample of pyridine which had been fractionated several times and was without doubt practically pure, gave a value of 100 per cent strength.

We have examined, altogether, 17 samples of pyridine obtained from various sources, and, with the exception of 2 samples which were colored (yellow), all were suitable for use in the filter solutions. The titration tests gave values for these 17 samples ranging from 97 to 100 per cent strength. As shown in Section VIII, 2 (c) a departure

${ }_{12}$ We are indebted to I. M. Jacobsohn, of the chemistry division, for the fractional crystallization of pyridine and picoline. 
of a least 6 per cent from our standard of 98.4 per cent strength is necessary to affect the color of the filters as much as is caused by a 1 per cent error in the copper sulphate. It thus appears that for general use it is unnecessary to test pyridine by titrating for strength. Independent tests on Davis-Gibson filters made at the National Physical Laboratory of Great Britain have led to the same conclusion. (See quotation at end of Sec. VII, 8.)

The presence of the homologues might be indicated by treatment with potassium permanganate. However, the reaction is slow at room temperatures, and other reducing agents which may be present in pyridine react with the permanganate more rapidly than do the homologues. Although this makes the test of little value as a means of detecting the higher homologues, it is nevertheless useful in detecting the presence of other undesirable impurities. We recommend that the pyridine used in the filter solutions pass the following simple test: To 5 cc of pyridine add 2 drops of $N / 10 \mathrm{KMnO}_{4}$. This should remain red for at least an hour.

Pyridine should be kept in glass-stoppered bottles because it reacts with cork, becoming yellow. Pyridine so contaminated will not pass the permanganate test. We would strongly recommend that in purchasing pyridine, glass-stoppered bottles be specified.

\section{(d) MANNITE}

This material $\left(\mathrm{C}_{6} \mathrm{H}_{8}(\mathrm{OH})_{6}\right)$, also referred to as $d$-mannitol is one of the sugar alcohols. It is commercially obtainable as fine white needles which melt at $166^{\circ} \mathrm{C}$. The mannite used in this work was prepared from crude manna and purified by recrystallization from water solution by the polarimetry section of the bureau. This mannite was compared by C. F. Snyder, polarimetry section, with a sample from the Eastman Kodak Co. in the following test:

Optical rotation.- Ten grams of $d$-mannitol and $10 \mathrm{~g}$ of borax were dissolved in water and the volume made up to $100 \mathrm{ml}$ at $20^{\circ} \mathrm{C}$. The solutions were filtered and observed on a Bates type saccharimeter using white-light illumination. From the values so obtained the specific rotations for sodium light were calculated. The same value was obtained for both samples, viz, $+20.9^{\circ}$ (with borax) for the $\mathrm{D}$ line at $20^{\circ} \mathrm{C}$. (The specific rotation of mannite is greatly increased by borax. In simple aqueous solution the specific rotation is very small.)

Melting point.-Determinations on the two samples showed for the Eastman sample, M. P. $=+166^{\circ}$ C., and for the Bureau of Standards sample, M. P. $=+165^{\circ} \mathrm{C}$.

The use of mannite in the filter is that of a stabilizer. Any rotatory power possessed by the solution containing mannite need have no influence on the color and the spectral energy distribution of the lamp and filter combination. Rotatory effects could be important only if the filter were placed between a polarizer and analyzer, and such an arrangement need never be used. In cases where the intensity of light is modified by polarization methods, any rotatory powers that the filter might have could be nullified by placing the filter elsewhere than between the polarizing elements.

Furthermore, even these precautions are entirely unnecessary as is shown by the following test, made by F. P. Phelps of the polarimetry 
section of the bureau, on the A solution (containing mannite) of the $2,360^{\circ} \mathrm{K}$-to-mean-sun filter:

The rotation was measured in a $20-\mathrm{mm}$ tube.

The estimated experimental error is about $\pm 0.005^{\circ}$.

1. The observed rotation for the band (blue) transmitted by the tube of solution when illuminated by white light from a 100-watt tungsten stereoptican lamp was___.

2. The observed rotation for $\lambda=546$ was $\ldots \ldots \ldots 5^{\circ}$

3. The observed rotation for $\lambda=578$ was

4. When a red screen was interposed under the conditions of (1), so much light was absorbed that no reading could be made.

It will be seen that while all the readings obtained are positive, their magnitude is well within the experimental error. The rotation, therefore, if any, is so small as to be entirely negligible.

\section{(e) AMMONIA}

Ammonium hydroxide (ammonia water) is easily obtained in high purity. The strength of the usual C. P. grade is about 28 per cent $\mathrm{NH}_{3}$. It is well known that ammonia water is unstable at ordinary temperatures, decomposing into water and ammonia gas, and it is thus necessary to determine the $\mathrm{NH}_{3}$ content before using. In our work Baker and Adamson ammonia water of C. P. quality was used. The $\mathrm{NH}_{3}$ content was tested by standard titration methods immediately before using, and the quantity used in preparing the solutions was adjusted in all cases so as to obtain the equivalent of 28 per cent ammonia water.

\section{METHODS OF COMPUTATION}

\section{SPECTROPHOTOMETRIC TERMINOLOGY}

Before describing the various computations required in the design of the filters, it is necessary to define precisely the various spectrophotometric terms which are used. Throughout the paper, both before and following the present section, these terms are used in strict accord with these definitions.

Let radiant energy, homogeneous with respect to wave length, be incident perpendicularly upon the first surface of a homogeneous, isotropic, nondiffusing medium or series of such media in contact with one another, having plane, nondiffusing, parallel surfaces, and after passage through the medium or media emerge perpendicularly from the last surface. If $E_{1}$ be the energy thus incident upon the first surface and $E_{2}$ the energy thus leaving the last surface in the same direction as $E_{1}$, then transmission, $T$, is defined as:

$$
T=\frac{E_{2}}{E_{1}}
$$

Thus, we may refer to the transmission of a plate of glass, or a cell with glass end plates containing a solution, or of the two-compartment filters herein described, in all cases referring to the ratio of the energies transmitted by and incident (normally) upon the material or group of materials under consideration.

Density, $D$, is defined as the negative logarithm of the transmiscion, thus:

$$
D=-\log _{10} T
$$


Consider further a substance in homogeneous solution in a solvent contained in a cell with plane, parallel sides, perpendicular to the direction of propagation of energy. Let $T_{s o l}$ be the transmission of a cell containing the solution, and let $T_{\text {sov }}$ be the transmission of the same or a similar cell filled with the solvent. Then transmittancy, $\mathrm{T}$, is defined as:

$$
\mathrm{T}=T_{\text {sol }} / T_{\text {sov }}
$$

Throughout the present paper $T_{\text {sov }}$ refers to a cell containing distilled water only.

Absorbancy, A, is defined as the negative logarithm of the transmittancy, thus:

$$
A=-\log _{10} T
$$

Let $b$ and $c$ refer to the thickness and concentration, respectively, of a solution. The quantity $\mathbf{k}$, equal to $\mathbf{A} / b c$, is known as the specific absorptive index. Its magnitude depends, of course, upon the particular units chosen for thickness and concentration. The relation, $\mathbf{A}=\mathbf{k} b c$, is known as Beer's law. For a given concentration, $\mathbf{A}=\mathbf{k}^{\prime} b$. This relation is known as Lambert's law and may be derived from theoretical considerations. The analogous relation, with thickness constant, viz, $\mathbf{A}=\mathbf{k}^{\prime \prime} c$, may or may not be valid, depending upon the particular solution. Failure of Beer's law always refers to a failure of this last relation.

The terms transmission, transmittancy, and density, as defined above, are in accordance with the terminology of the O. S. A. committee report on spectrophotometry (35, p. 177). The primary meaning of density as used in photographic sensitometry has more nearly the meaning of absorbancy than of density as defined in this paper. In the present case, it is thought best to use the terminology developed for spectrophotometric work. The quantity $\mathbf{k}(=\mathbf{A} / b c)$ was defined in the O. S. A. committee report as the specific transmissive index, but it seems more appropriate to name it the specific absorptive index, as has been done by Peters and Phelps (36, p. 265) and Brode (37, p. 503).

The term absorbancy was used by Peters and Phelps to represent the quantity $1-\mathrm{T}$ instead of $-\log _{10} \mathrm{~T}$ as defined above; however, the need for a word or symbol to designate $1-\mathrm{T}$ is not so pronounced. In discussions of the absorptive properties of solutions, on the other hand, the negative logarithm of the transmittancy is one of the most commonly used quantities. Hitherto, the terms density and extinction coefficient have often been used in this connection, but there are objections to both expressions. Density is widely used in photographic work where it usually has reference to transmittancy that is more or less diffused, in addition to its use in the consideration of rectilinear transmission as defined above. Extinction coefficient is an unsatisfactory expression, for, when used in this sense, it is not a coefficient and in its derivation does not accord with the usual meaning of extinction. The use of the word absorbancy eliminates the need for these expressions and with its symbol A makes unnecessary the continual repetition of the cumbersome expressions $-\log _{10}$ transmittancy and $-\log _{10} \mathrm{~T}$. 


\section{STANDARD SPECTROPHOTOMETRIC DATA}

With solutions of medium concentration selected as noted in Section IV, 1, and by spectrophotometric methods described in detail in Section VII, standard absorbancy values were adopted for the component solutions and standard density values for the double cell filled with water. These fundamental values are given in Tables 4,

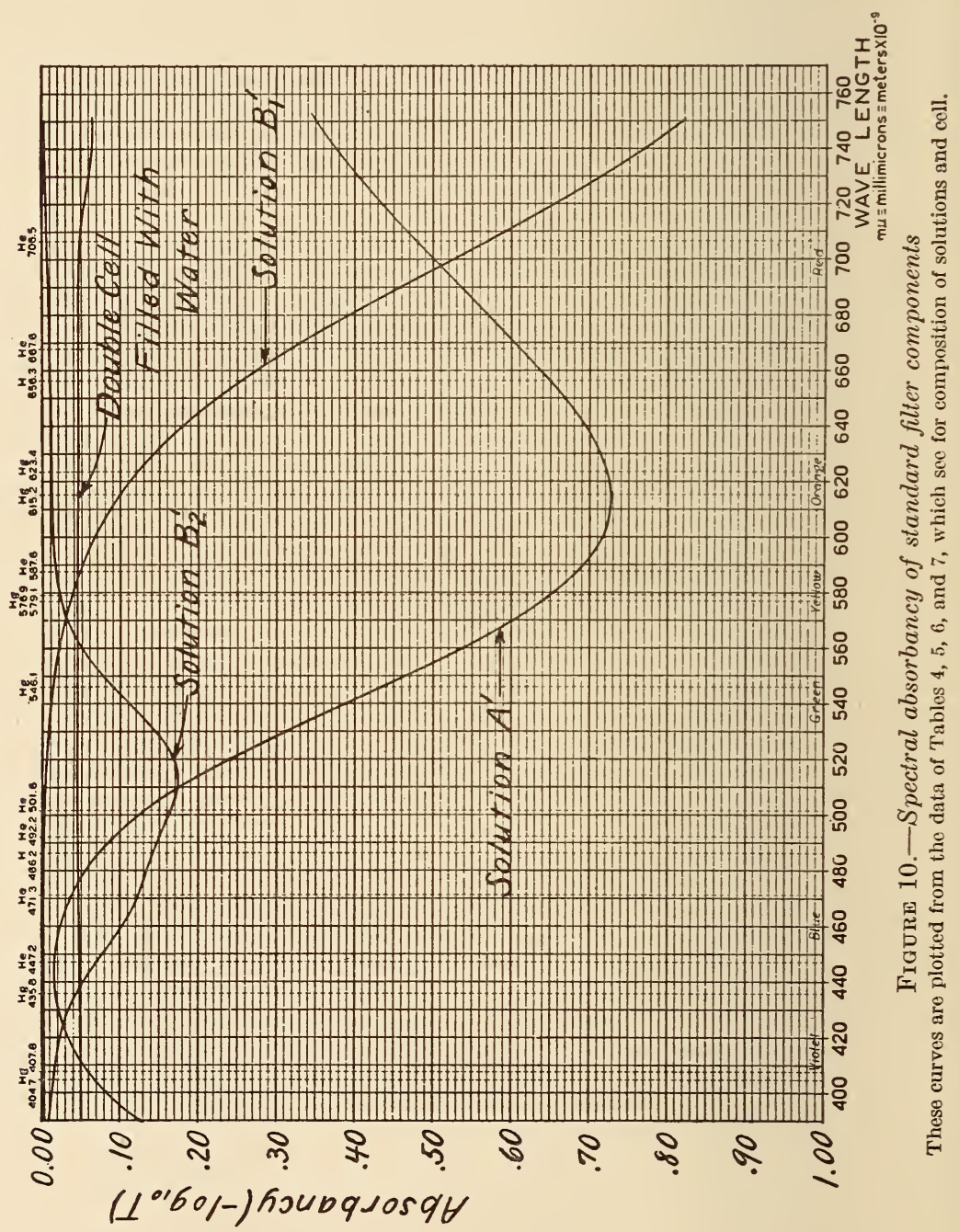

5,6 , and 7 , and illustrated in Figure 10; in the tables are also given values of absorbancy on a $1 \mathrm{~g}$ basis as used in the computations, values of the Beer's law correction factor for the A solutions, and values of transmittancy and transmission derived, respectively, from the absorbancy and density values. Values of absorbancy for any concentration may be computed by multiplying the $1 \mathrm{~g}$ absorbancy values by the concentration in grams, provided that any Beer's law failure is allowed for in such computation. As noted elsewhere, a 
Beer's law correction was necessary only with the A solutions and the method of applying it is described in the next section.

The advantage of using the negative logarithms of spectral transmission and transmittancy in computations involving the combination of two or more materials may be noted here. Let $D_{W}$ represent the density of a double cell, such as used in the present filters, when filled with distilled water, and $D_{F}$ the density of the same cell when filled with the $A$ and $B$ solutions. Furthermore, let $A_{A}, A_{B 1}, A_{B 2}$, and $A_{B}$ refer, respectively, to the absorbancies of the $A, B_{1}, B_{2}$, and $B$ solutions. Then, at any wave length,

or

$$
D_{F}=D_{W}+\mathrm{A}_{A}+\mathrm{A}_{B}
$$

$$
D_{F}=D_{W}+\mathrm{A}_{A}+\mathrm{A}_{B_{1}}+\mathrm{A}_{B_{2}}
$$

For the computations in which we are interested these are simpler formulas than the corresponding ones,

and

$$
T_{F}=T_{W} \times \mathrm{T}_{A} \times \mathrm{T}_{B}
$$

$$
T_{F}=T_{W} \times \mathrm{T}_{A} \times \mathrm{T}_{B_{1}} \times \mathrm{T}_{B_{2}}
$$

TABLE 4.-Standard spectrophotometric data for solution $A^{\prime}$

Unfiltered, thickness $10.00 \mathrm{~mm}$, temperature $25^{\circ} \mathrm{C}$, having the following composition:

Copper sulphate $\left(\mathrm{CuSO}_{4} .5 \mathrm{H}_{2} \mathrm{O}\right)_{1}$

Mannite $\left(\mathrm{C}_{6} \mathrm{H}_{8}(\mathrm{OH})_{6}\right)_{2}$

3. 000

\begin{tabular}{|c|c|c|c|c|c|c|c|c|c|}
\hline $\begin{array}{l}\text { Wave length in } \\
\text { millimicrons }\end{array}$ & $\begin{array}{c}\text { Absorb- } \\
\text { ancy } \\
\text { A }_{0} \\
\left(c_{s}=3\right)\end{array}$ & $\frac{A_{8}}{c_{8}}$ & $\begin{array}{l}\text { Beer's } \\
\text { law cor- } \\
\text { rection } \\
\text { factor }{ }^{3} \\
\text { :B }\end{array}$ & $\begin{array}{c}\text { Trans- } \\
\text { mit- } \\
\text { tancy } \\
T_{.}\end{array}$ & $\begin{array}{l}\text { Wave length in } \\
\text { millimicrons }\end{array}$ & $\begin{array}{c}\text { Absorb- } \\
\text { ancy } \\
A_{s} \\
c_{s}=3\end{array}$ & $\frac{A_{s}}{c_{s}}$ & $\begin{array}{c}\text { Beer's } \\
\text { law cor- } \\
\text { rection } \\
\text { factor }{ }^{3} \\
\text { B }\end{array}$ & $\begin{array}{c}\text { Trans- } \\
\text { mit- } \\
\text { tancy }{ }^{4} \\
T_{.}\end{array}$ \\
\hline $\begin{array}{l}0- \\
0- \\
0-\end{array}$ & $\begin{array}{r}0.470 \\
.360 \\
.267 \\
.190 \\
.127\end{array}$ & $\begin{array}{r}0.156667 \\
.120000 \\
.089000 \\
.063333 \\
.042333\end{array}$ & $\begin{array}{r}-0.120 \\
.120 \\
.118 \\
.114 \\
.105\end{array}$ & $\begin{array}{r}0.339 \\
.437 \\
.541 \\
.646 \\
.746\end{array}$ & $\begin{array}{l}600 \ldots \\
610_{-} \\
620= \\
630= \\
640=\end{array}$ & $\begin{array}{l}0.717 \\
.726 \\
.725 \\
.714 \\
.696\end{array}$ & $\begin{array}{l}0.239000 \\
.242000 \\
.241667 \\
.238000 \\
.232000\end{array}$ & $\begin{array}{r}-0.010 \\
.010 \\
.010 \\
.010 \\
.010\end{array}$ & $\begin{array}{r}0.192 \\
.188 \\
.188 \\
.193 \\
.201\end{array}$ \\
\hline 400 & $\begin{array}{l}.0835 \\
.053 \\
.033 \\
.0215 \\
.0165\end{array}$ & $\begin{array}{l}.027833 \\
.017667 \\
.011000 \\
.007167 \\
.005500\end{array}$ & $\begin{array}{l}.080 \\
.050 \\
.032 \\
.020 \\
.013\end{array}$ & $\begin{array}{l}.825 \\
.885 \\
.927 \\
.952 \\
.963\end{array}$ & $\begin{array}{l}650 \\
660 \\
670 \\
680 \\
690\end{array}$ & $\begin{array}{l}.668 \\
.637 \\
.603 \\
.570 \\
.536\end{array}$ & $\begin{array}{l}.222667 \\
.212333 \\
.201000 \\
.190000 \\
.178667\end{array}$ & $\begin{array}{l}.010 \\
.010 \\
.010 \\
.010 \\
.010\end{array}$ & $\begin{array}{l}.215 \\
.231 \\
.249 \\
.269 \\
.291\end{array}$ \\
\hline $\begin{array}{l}450 . \\
460- \\
470- \\
480_{-} \\
490_{-}\end{array}$ & $\begin{array}{l}.017 \\
.023 \\
.0355 \\
.0555 \\
.035\end{array}$ & $\begin{array}{l}.005667 \\
.007667 \\
.011833 \\
.018500 \\
.028333\end{array}$ & $\begin{array}{l}.010 \\
.010 \\
.010 \\
.010 \\
.010\end{array}$ & $\begin{array}{l}.962 \\
.948 \\
.922 \\
.880 \\
.822\end{array}$ & $\begin{array}{l}700 \ldots \\
710-\ldots \\
720 \\
730 \ldots \\
740 \\
\end{array}$ & $\begin{array}{l}.501 \\
.468 \\
.435 \\
.405 \\
.377\end{array}$ & $\begin{array}{r}.167000 \\
.156000 \\
.145000\end{array}$ & $\begin{array}{l}.010 \\
.010 \\
.010\end{array}$ & $\begin{array}{l}.316 \\
.340 \\
.367 \\
.394 \\
.420\end{array}$ \\
\hline $\begin{array}{l}20- \\
30- \\
10-\end{array}$ & $\begin{array}{l}.123 \\
.175 \\
.240 \\
.311 \\
.387\end{array}$ & $\begin{array}{l}.041000 \\
.058333 \\
.080000 \\
.103667 \\
.129000\end{array}$ & $\begin{array}{l}.010 \\
.010 \\
.010 \\
.010 \\
.010\end{array}$ & $\begin{array}{l}.753 \\
.668 \\
.575 \\
.489 \\
.410\end{array}$ & $\begin{array}{l}750 \\
\text { Hg } 404.7 \\
\text { Hg } 435.8 \\
\text { Hg } 491.6 \\
\text { He } 501.6\end{array}$ & $\begin{array}{l}.351 \\
\\
.068 \\
.018 \\
.091 \\
.131\end{array}$ & & $\begin{array}{l}.065 \\
.016 \\
.010 \\
.010\end{array}$ & $\begin{array}{l}.855 \\
.959 \\
.811 \\
.740\end{array}$ \\
\hline $\begin{array}{l}550 \\
560 \\
570 \\
580 \\
590\end{array}$ & $\begin{array}{l}.464 \\
.538 \\
.603 \\
.655 \\
.693\end{array}$ & $\begin{array}{l}.154667 \\
.179333 \\
.201000 \\
.218333 \\
.231000\end{array}$ & $\begin{array}{l}.010 \\
.010 \\
.010 \\
.010 \\
.010\end{array}$ & $\begin{array}{l}.344 \\
.290 \\
.249 \\
.221 \\
.203\end{array}$ & $\begin{array}{l}\mathrm{Hg} 546.1 \\
\mathrm{Hg} 578.0 \ldots \\
\mathrm{He} 587.6 \\
\mathrm{He} 667.8\end{array}$ & $\begin{array}{l}.434 \\
.646 \\
.685 \\
.610\end{array}$ & & $\begin{array}{l}.010 \\
.010 \\
.010 \\
.010\end{array}$ & $\begin{array}{l}.368 \\
.226 \\
.207 \\
.245\end{array}$ \\
\hline
\end{tabular}

3. 000

30.0

Water (distilled) to make.

1 Chemical analysis showed the copper sulphate to have 99.7 per cent of the theoretical copper content. 2 Titration showed the pyridine to have an effective strength of 98.4 per cent, this including $2 \frac{1}{2}$ per cent picoline impurity.

${ }_{3}$ The Beer's law correction factor is applied as follows (see Sec. V, 3):

Note that $B$ is a negative quantity.

$$
A=\frac{A_{s}}{c_{s}} c\left[1+B\left(c-c_{s}\right)\right]
$$

1 These values of tranșițtancy are derived from the adopted values of absorbancy. $A_{8}=-\log _{10} \mathrm{~T}_{8}$. 


\section{TABLE 5.-Standard spectrophotometric data for solution $B_{1}{ }^{\prime}$}

Unfiltered, thickness $10.00 \mathrm{~mm}$, temperature $25^{\circ} \mathrm{C}$., having the following composition:

Copper sulphate $\left(\mathrm{CuSO}_{4} .5 \mathrm{H}_{2} \mathrm{O}\right)^{1}$

Sulphuric acid (specific gravity 1.835)

20. 000

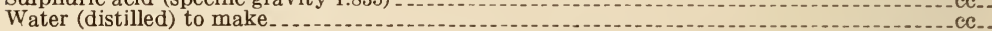

\begin{tabular}{|c|c|c|c|c|c|c|c|}
\hline $\begin{array}{l}\text { Wave length in } \\
\text { millimicrons }\end{array}$ & $\begin{array}{c}\text { Absorb- } \\
\text { ancy } \\
A_{8}\end{array}$ & $\frac{A_{8}}{20}$ & $\begin{array}{c}\text { Trans- } \\
\text { mit- } \\
\text { tancy }^{2} \\
T_{s}\end{array}$ & $\begin{array}{l}\text { Wave length in } \\
\text { millimicrons }\end{array}$ & $\begin{array}{c}\text { Absorb- } \\
\text { ancy } \\
A_{8}\end{array}$ & $\frac{A_{8}}{20}$ & $\begin{array}{c}\text { Trans- } \\
\text { mit- } \\
\text { tancy }{ }^{2} \\
T_{.}\end{array}$ \\
\hline 390 & $\begin{array}{r}0.0090 \\
.0063 \\
.0046 \\
.0035 \\
.0028\end{array}$ & $\begin{array}{r}0.000450 \\
.000315 \\
.000230 \\
.000175 \\
.000140\end{array}$ & $\begin{array}{r}0.979 \\
.988 \\
.989 \\
.992 \\
.994\end{array}$ & $\begin{array}{l}600 \\
610 \\
620 \\
630\end{array}$ & $\begin{array}{l}0.0680 \\
.0885 \\
.1125 \\
.143 \\
.180\end{array}$ & $\begin{array}{r}0.003400 \\
.004425 \\
.005625 \\
.007150 \\
.009000\end{array}$ & $\begin{array}{l}0.855 \\
.816 \\
.772 \\
.719 \\
.661\end{array}$ \\
\hline $\begin{array}{l}420 \ldots \ldots \\
430 \ldots \\
440 \ldots\end{array}$ & $\begin{array}{l}.0023 \\
.0019 \\
.0016 \\
.0014 \\
.0012\end{array}$ & $\begin{array}{l}.000115 \\
.000095 \\
.000080 \\
.000070 \\
.000060\end{array}$ & $\begin{array}{l}.995 \\
.996 \\
.996 \\
.997 \\
.997\end{array}$ & $\begin{array}{l}650 \\
660 \\
670 \\
680 \\
690\end{array}$ & $\begin{array}{l}.224 \\
.274 \\
.332 \\
.392 \\
.459\end{array}$ & $\begin{array}{l}.011200 \\
.013700 \\
.016600 \\
.019600 \\
.022950\end{array}$ & $\begin{array}{l}.597 \\
.532 \\
.466 \\
.406 \\
.348\end{array}$ \\
\hline & $\begin{array}{l}.0011 \\
.0011 \\
.0012 \\
.0014 \\
.0018\end{array}$ & $\begin{array}{l}.000055 \\
.000055 \\
.000060 \\
.000070 \\
.000090\end{array}$ & $\begin{array}{l}.997 \\
.997 \\
.997 \\
.997 \\
.996\end{array}$ & $\begin{array}{l}700 \\
710 \\
720 \\
730 \\
740\end{array}$ & $\begin{array}{l}.527 \\
.592 \\
.656 \\
.715 \\
.768\end{array}$ & $\begin{array}{l}.026350 \\
.029600 \\
.032800\end{array}$ & $\begin{array}{l}.297 \\
.256 \\
.221 \\
.193 \\
.171\end{array}$ \\
\hline 500 & $\begin{array}{l}.0026 \\
.0038 \\
.0055 \\
.0079 \\
.0111\end{array}$ & $\begin{array}{l}.000130 \\
.000190 \\
.000275 \\
.000395 \\
.000555\end{array}$ & $\begin{array}{l}.994 \\
.991 \\
.987 \\
.982 \\
.975\end{array}$ & $\begin{array}{l}750 \\
\mathrm{Hg} 404.7 \\
\mathrm{Hg} 435.8 \\
\mathrm{Hg}\end{array}$ & $\begin{array}{l}.817 \\
.0021 \\
.0013 \\
.0019\end{array}$ & & $\begin{array}{l}.152 \\
.995 \\
.997 \\
.996\end{array}$ \\
\hline $\begin{array}{l}550 \\
5600 \\
580 \\
590\end{array}$ & $\begin{array}{l}.0155 \\
.0216 \\
.0292 \\
.0390 \\
.0518\end{array}$ & $\begin{array}{l}.000775 \\
.001080 \\
.001460 \\
.001950 \\
.002590\end{array}$ & $\begin{array}{l}.965 \\
.951 \\
.935 \\
.914 \\
.888\end{array}$ & $\begin{array}{l}\text { He } 501.6 \\
\text { Hg } 546.1 \\
\text { Hg } 578.0 \\
\text { He } 587.6 \\
\text { He } 667.8\end{array}$ & $\begin{array}{l}.0028 \\
.0135 \\
.0368 \\
.0487 \\
.319\end{array}$ & & $\begin{array}{l}.994 \\
.969 \\
.919 \\
.894 \\
.480\end{array}$ \\
\hline
\end{tabular}

1 Analysis showed the copper sulphate to have 99.7 per cent of the theoretical copper content.

2 These values of transmittancy are derived from the adopted values of absorbancy. $A_{8}=-\log _{10} T_{\text {. }}$.

TABLE 6.-Standard spectrophotometric data for solution $B^{\prime}{ }_{2}$

Unfiltered, thickness $10.00 \mathrm{~mm}$, temperature $25^{\circ} \mathrm{C}$., having the following composition: 1

Cobalt ammonium sulphate $\left(\mathrm{CoSO}_{4} \cdot\left(\mathrm{NH}_{4}\right)_{4} \mathrm{SO}_{4} .6 \mathrm{H}_{2} \mathrm{O}\right)^{2}$ Sulphuric acid (specific gravity 1.835)

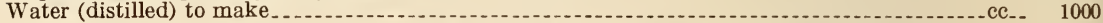

\begin{tabular}{|c|c|c|c|c|c|c|c|}
\hline $\begin{array}{l}\text { Wave length in milli- } \\
\text { microns }\end{array}$ & $\begin{array}{c}\text { Absorb- } \\
\text { ancy } \\
\mathbf{A}_{s}\end{array}$ & $\frac{A_{s}}{14.481}$ & $\begin{array}{l}\text { Trans- } \\
\text { mit- } \\
\text { tancy }^{3} \\
T_{s}\end{array}$ & $\begin{array}{l}\text { Wave length in milli- } \\
\text { microns }\end{array}$ & $\begin{array}{c}\text { Absorb- } \\
\text { ancy } \\
A_{8}\end{array}$ & $\frac{A_{8}}{14.481}$ & $\begin{array}{l}\text { Trans- } \\
\text { mit- } \\
\text { tancy }^{3} \\
T_{8}\end{array}$ \\
\hline 0 & $\begin{array}{r}0.0038 \\
.0040 \\
.0050 \\
.0065 \\
.0088\end{array}$ & $\begin{array}{l}0.0002624 \\
.0002762 \\
.0003453 \\
.0004489 \\
.0006077\end{array}$ & $\begin{array}{r}0.991 \\
.991 \\
.989 \\
.985 \\
.980\end{array}$ & 6000 & $\begin{array}{r}0.0137 \\
.0124 \\
.0115 \\
.0112 \\
.0110\end{array}$ & $\begin{array}{l}0.0009461 \\
.0008563 \\
.0007941 \\
.0007734 \\
.0007596\end{array}$ & $\begin{array}{r}0.969 \\
.972 \\
.974 \\
.975 \\
.975\end{array}$ \\
\hline 40 & $\begin{array}{l}.0125 \\
.0168 \\
.0224 \\
.0340 \\
.0522\end{array}$ & $\begin{array}{l}.0008632 \\
.0011601 \\
.0015469 \\
.0023479 \\
.0036047\end{array}$ & $\begin{array}{l}.972 \\
.962 \\
.950 \\
.925 \\
.887\end{array}$ & 6506 & & $\begin{array}{l}.0007251 \\
.0006698 \\
.0006008 \\
.0005248 \\
.0004558\end{array}$ & $\begin{array}{l}.976 \\
.978 \\
.980 \\
.983 \\
.985\end{array}$ \\
\hline 50 & & $\begin{array}{l}.0053380 \\
.0071197 \\
.0083765 \\
.0093157 \\
.0101650\end{array}$ & $\begin{array}{l}.837 \\
.789 \\
.756 \\
.733 \\
.713\end{array}$ & $\begin{array}{l}700 \\
710 \\
720 \\
730 \\
740\end{array}$ & $\begin{array}{l}.0054 \\
.0046 \\
.0038 \\
.0032 \\
.0030\end{array}$ & $\begin{array}{r}.0003729 \\
.0003177 \\
.0002624 \\
\end{array}$ & $\begin{array}{l}.988 \\
.989 \\
.991 \\
.993 \\
.993\end{array}$ \\
\hline $\begin{array}{l}500 \\
510 \\
520\end{array}$ & $\begin{array}{l}.1635 \\
.1742 \\
.1689 \\
.1452 \\
.1113\end{array}$ & $\begin{array}{l}.0112907 \\
.0120296 \\
.0116636 \\
.0100269 \\
.0076859\end{array}$ & $\begin{array}{l}.686 \\
.670 \\
.678 \\
.716 \\
.774\end{array}$ & $\begin{array}{l}750 \\
\mathrm{Hg} 404.7 \\
\mathrm{Hg}-435.8 \\
\mathrm{Hg} \\
491.6\end{array}$ & $\begin{array}{l}.0028 \\
.0144 \\
.0437 \\
.1497 \\
1661\end{array}$ & & $\begin{array}{l}.994 \\
.967 \\
.904 \\
.708 \\
.682\end{array}$ \\
\hline 580 & $\begin{array}{l}.0775 \\
.0496 \\
.0308 \\
.0207 \\
.0158\end{array}$ & $\begin{array}{l}.0053518 \\
.0034252 \\
.0021269 \\
.0014295 \\
.0010911\end{array}$ & $\begin{array}{l}.837 \\
.892 \\
.932 \\
.953 \\
.964\end{array}$ & $\begin{array}{l}\text { He } 501.6 \\
\text { Hg } 546.1 \\
\text { Hg } 578.0 \\
\text { He } 587.6 \\
\text { He } 667.8\end{array}$ & $\begin{array}{l}.1661 \\
.0901 \\
.0219 \\
.0167 \\
.0089\end{array}$ & & $\begin{array}{l}.682 \\
.813 \\
.951 \\
.962 \\
.980\end{array}$ \\
\hline
\end{tabular}

1 These data apply accurately also throughout the visible spectrum to a similar solution made up with $10.3 \mathrm{~g}$. of cobalt sulphate $\left(\mathrm{CoSO}_{4} .7 \mathrm{H}_{2} \mathrm{O}\right)$.

2 Chemical analysis showed a cobalt (plus nickel) content of 100.0 per cent of the theoretical, the ratio of nickel to cobalt (metals) being 1 to 200.

3 These values of transmittancy are derived from the adopted values of absorbancy. $A_{8}=-\log _{10} T_{8}$. 
TABLE 7.-Standard spectrophotometric data on double cell filled with water

Three glass plates, each $2.5 \mathrm{~mm}$ thick (borosilicate crown, refractive index, $D$ line $=1.51$ ), two $1.000 \mathrm{~cm}$ thicknesses of distilled water; two air-glass surfaces, four water-glass surfaces.

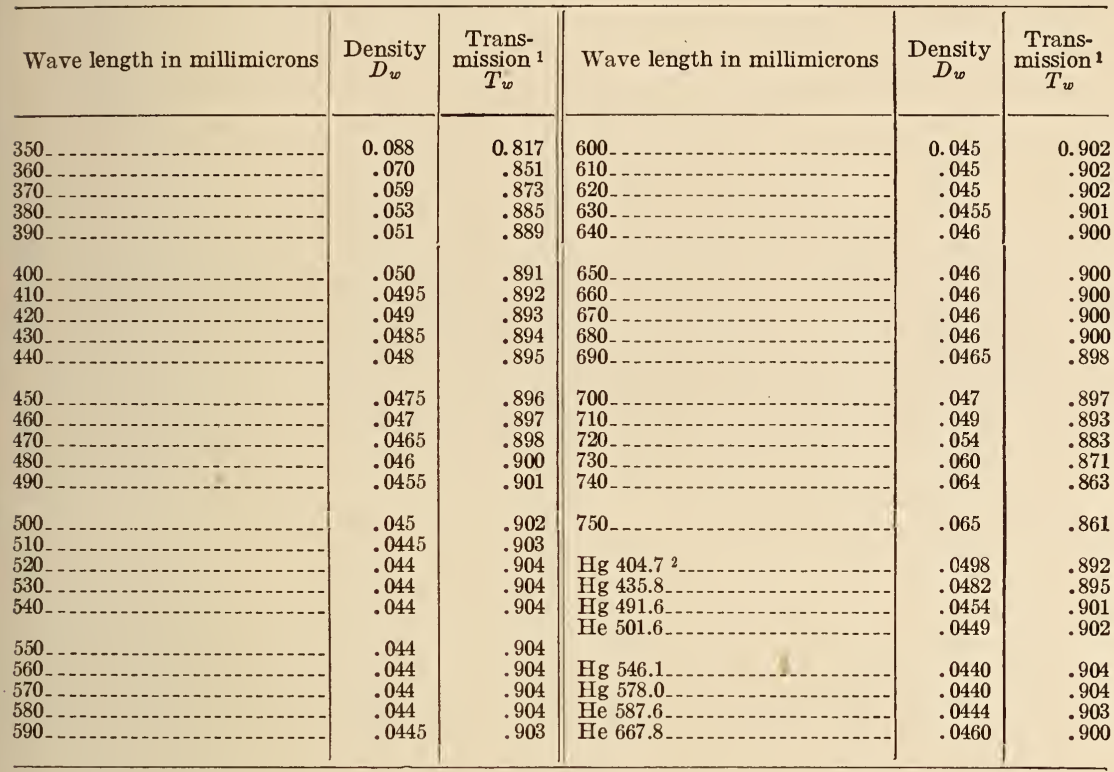

1 Values of transmission are derived from the adopted values of density. $D_{w}=-\log _{10} T_{x}$.

2 These values for the $\mathrm{Hg}$ and $\mathrm{He}$ wave lengths are not fundamental experimental values as in the case of the solutions, tables 4 to 6 , but are interpolated from the adopted density values above from $350 \mathrm{~m}_{\mu}$ to $750 \mathrm{~m} \mu$.

\section{BEER'S LAW CORRECTION FOR SOLUTION A}

Let $A$ be the absorbancy, at any wave length, of a solution having a concentration of $c$ grams per liter, and $\mathbf{A}_{s}$ the standard absorbancy at the same wave length, for a concentration $c_{s}(=3.000 \mathrm{~g})$ as given in Table 4, thicknesses in both cases being equal to $10 \mathrm{~mm}$. If there is no Beer's law failure,

$$
\mathrm{A}=\frac{c}{c_{s}} \mathrm{~A}_{s}
$$

If $B$ represents the Beer's law correction factors given in Table 4, then $B$ may be defined as

$$
B=\frac{\mathrm{A}\left(\frac{c_{s}}{c}\right)-\mathbf{A}_{s}}{\left(c-c_{s}\right) \mathbf{A}_{s}}
$$

Rearranging this equation gives

$$
\mathrm{A}=\frac{\mathbf{A}_{s}}{c_{s}} c\left[1+B\left(c-c_{s}\right)\right]
$$

In the case of the $A$ solutions, $B$ is a negative quantity, as may be seen by reference to the experimental data of Table 17 (see Sec. VII, 6 ), which results in the correction being negative when $c>c_{s}$ and positive when $c<c_{s}$. 
This formula was used in all computations of $A, \frac{A_{3}}{c_{3}}$ being computed and tabulated once for all as in Table 4 . The fact that $B$ is constant from $450 \mathrm{~m} \mu$ to $720 \mathrm{~m} \mu$ simplified the work of correction.

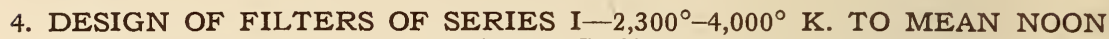 SUNLIGHT}

\section{(a) TO OBTAIN SPECTRAL ENERGY MATCH}

Obviously the first step in the design of a filter to convert one spectral energy distribution, $E$, to another, $E^{\prime}$, is the computation of the relative spectral transmission of the ideal filter. This is obtained by computing, wave length by wave length, values of $E^{\prime} / E$. These values of $E^{\prime} \mid E$ have a value of unity at $560 \mathrm{~m} \mu$ since the relative energies are all given with reference to 100 at this wave length. They may be reduced to a practical working basis by multiplying them by an appropriate factor, known by trial and experience to bring the relative transmissions, on the average, close to the spectral transmission of the final filter.

The next problem is to find what concentrations of the component solutions, $\mathrm{A}, \mathrm{B}_{1}$, and $\mathrm{B}_{2}$ (considering also, of course, the data for the double cell filled with water) will best approximate the desired transmission or density.

The method devised for comparing the density of the ideal filter with the combined absorbancies of the three solutions at the trial concentrations plus the density of the cell filled with water is, briefly, as follows: A table of spectral absorbancies was prepared for each of the three solutions at a series of concentrations for the 17 spectral positions (every $20 \mathrm{~m} \mu$ ) from $400 \mathrm{~m} \mu$ to $720 \mathrm{~m} \mu$, inclusive. The concentrations of solution A were in $0.1 \mathrm{~g}$ steps, and of solutions $\mathrm{B}_{1}$ and $\mathrm{B}_{2}$ in $1.0 \mathrm{~g}$ steps. The absorbancies for each concentration were placed in horizontal rows, the values in the rows being arranged in order of wave lengths. A table of the spectral density values of the various ideal filters was also prepared.

These tables were mounted on rollers and placed in a box with a cover having slots so placed that one line of figures across each table is exposed to view. This is illustrated in Figure 11. The top roller contains the table of the spectral densities of the various ideal filters, the second line of figures, not mounted on a roller, are density values of the cell filled with water. The next three rollers contain the tables of the spectral absorbancies for solutions $A, B_{1}$, and $B_{2}$, respectively. The rollers may be turned by the handles outside of the box to expose to view any of the rows (horizontal) of figures. The cover of the box is ruled into 18 columns (vertical). In the first column, on the rollers, are the concentrations of the solutions in grams per liter and the name of the ideal filter. In the next 17 columns are the densities and absorbancies corresponding to the 17 wave lengths indicated at the tops of the columns. The operation of the device is as follows:

The three lower rollers are turned so as to expose the absorbancies corresponding to the concentrations of the solutions desired for the first trial. Next is found the difference between the density of the ideal filter and the sum of the absorbancies of the three solutions plus the density of the cell at each wave length. This requires but a 
Miscellaneous Publications, Bureau of Standards, No. 114

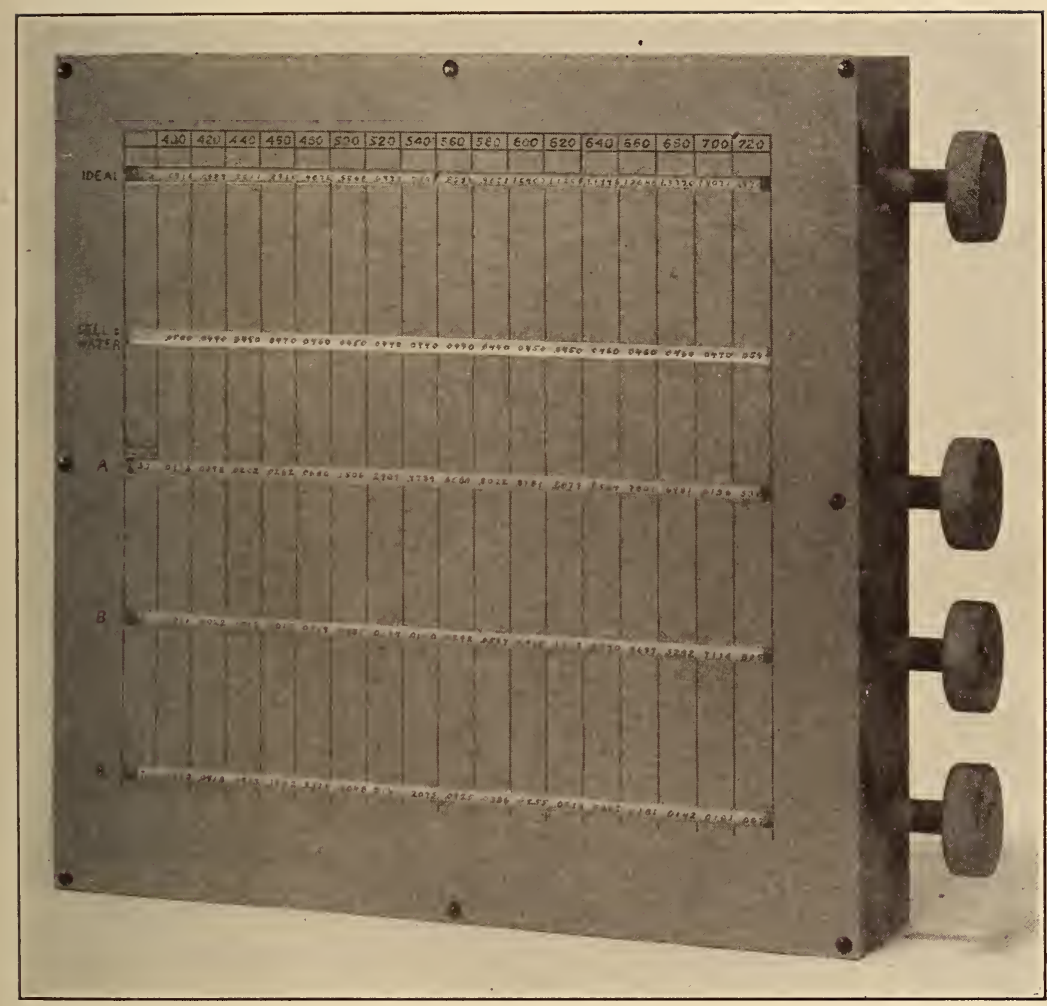

FIGURE 11.-Computing device used in design of filters Detailed explanation is given in Section V, $4(a)$. $13416^{\circ}-31-4$ 

few minutes with an adding or computing machine. The density differences are plotted on coordinate paper as a function of wave length. An ideal solution of the problem would be obtained if the density differences were equal in amount at all wave lengths.

Having thus plotted the density differences for the first trial, it is a relatively simple matter to determine what changes to make to improve the results, provided the general shape of the curve of each of the ingredients is kept in mind. These adjustments are made and the operation repeated until no further improvement can apparently be made. The length of time required to obtain satisfactory results by this method depends largely upon experience, from two to four hours work being usually necessary.

Other methods were considered before the one just described was adopted. For example, at each wave length there are three variables, and it would, therefore, be possible to choose three wave lengths fairly well distributed over the desired spectral range and make the actual and ideal values of density come into perfect agreement at these three wave lengths. However, the values at the remaining: wave lengths are beyond control; that is, the actual density curve makes excursions from the ideal at various points and the magnitude of these excursions will depend upon the three wave lengths chosen for the computation.

The method of least squares is also applicable to the problem, but is quite complicated because the importance at a given wave length of obtaining a close approximation varies with the color temperature of the sourcc. On this account a different set of weights would have to be employed for each source. It is not feasible to select one set of weights for each range of color temperature, because the continuity of the filters would be spoiled and interpolation for intermediate values would be difficult. The least square method appeared to be an unnecessary refinement.

The method finally adopted for solving the problem has advantages over either of these methods, chiefly because of its simplicity and flexibility. It allows some choice in the selection of concentrations so that a certain amount of control is possible over the light transmission of the filter. If the filter solutions had spectral properties such that a perfect match with the ideal filter could be obtained, no choice in concentrations would exist. However, this is not the case, since the actual densities depart from the ideal in several parts of the spectrum even at the most favorable concentrations. With low concentrations a good match in the central part of the visible spectrum is obtained with considerable departures at the ends; with higher concentrations the ends are improved considerably with increased departures in the central part of the spectrum.

Four filters, viz, $2,360^{\circ}, 2,600^{\circ}, 2,800^{\circ}$, and $3,000^{\circ} \mathrm{K}$. to mean sun, were first designed by the adopted method. The concentrations of the three solutions as abscissas and the color temperature as ordinates were plotted and curves drawn. These curves gave trial data for intermediate filters, final adjustment being made as before. The range of the filters was extended to $3,500^{\circ} \mathrm{K}$. and later to $4,000^{\circ} \mathrm{K}$. by the same process. All of the data so obtained were again plotted (concentrations against color temperature) and smooth average curves drawn. From these curves the concentrations were read, at every $100^{\circ}$ between the limits of $2,300^{\circ}$ and $4,000^{\circ} \mathrm{K}$., which were 
used for deriving the data for the trial computations of the colorimetric characteristics, as outlined in the next section.

\section{(b) TO OBTAIN COLOR MATCH}

It is possible for two spectral energy distributions to be widely different and still give the same color. If a color match between the artificial and adopted sunlight were the only concern, solution $\mathrm{B}_{1}$, for example, could be dispensed with. However, it is desirable for both photographic sensitometry and colorimetry that the spectral energy match be made as good as possible. This has been accomplished as outlined in the preceding section.

If it were possible to obtain, with the materials available, a perfect energy match with the ideal, a perfect color match would thereupon be automatically obtained. However, as previously noted, the energy distributions resulting from the process described in the preceding section depart from the ideal in several parts of the spectrum. From the magnitude and distribution of these deviations large color differences between the filtered energy and the ideal energy are not to be expected, and perfect color matches have been obtainable in all cases by making minor adjustments of the concentrations of one or more of the filter ingredients. Such adjustments do not materially change the energy matches previously obtained.

The method used for computing the color characteristics of any energy distribution follows the general description of such procedure as given in the Optical Society of America colorimetry report (4). The method makes use of the three so-called elementary excitations (red, green, and blue), based on the data of Abney and of Koenig and Dieterici as reduced by Weaver (4). These are given in Table 6 of the colorimetry report, but have been extrapolated and republished in the Optical Society of America spectrophotometry report (35), Table 5, page 230. These extrapolated excitations have been used in the present computations.

In addition to the choice of the red, green, and blue excitations, a spectral distribution defined as "neutral" (white) must be adopted. For this purpose the energy distribution of mean noon sunlight as given in Table 1 has been used. ${ }^{13}$ The methods of computation were as follows:

13 For the purposes of this paper, the computation of trilinear coordinates throughout the paper has been based on the arbitrary convention of making the center of the Maxwell triangle $(r=g=b=1 / 3)$ represent the spectral distribution which we have chosen for mean sun; that is, mean sun has been taken as the "neutral stimulus." The decision as to what stimulus should be given this central position is conditioned upon the specific purposes which the system of colorimetric coordinates is to serve.

The question as to what stimulus should be assigned this position for colorimetric purposes, in general, is at present being discussed by a committee of the International Commission on Illumination, but no final recommendation has been made; and the question as to whether "noon sun" or "overcast sky" or "sun outside the earth's atmosphere" or a "black body" at some specified temperature should be formally chosen for this purpose is still in abeyance.

The choice of spectral distribution which we have made to represent "mean sun" has been based primarily on the requirements which a standard for photographic sensitometry must meet. For some years previously a slightly different spectral distribution of energy proposed by Priest (3) has served as a standard for "average noon sunlight at Washington" in the colorimetry section of the bureau and, to some extent, elsewhere. Priest sought to represent, for colorimetric purposes, the same data which we have sought to represent for the purposes of photographic sensitometry; the spectral distribution of energy he adopted is designated as "Abbot-Priest sun" throughout the present paper.

It may be noted that if "noon sun" should be formally chosen by the International Committee on nlumination to be placed at the center of the Maxwell triangle, Davis-Gibson mean sun would be equally as eligible to represent "noon sun" for this purpose as a black body at $5,000^{\circ} \mathrm{K}$., "O. S. A. noon sun," or Abbot-Priest sun.

Naturally, for the purposes of this paper, it has been convenient to represent our ideal energy distribution (Davis-Gibson mean sun) by $r=g=b=1 / 3$; that is, it has been convenient to make Davis-Gibson mean sun the "neutral stimulus." Because of this difference in "neutral stimulus," the results of our computations of trilinear coordinates differ slightly from those which would be obtained on the basis of AbbotPriest sun, which is placed at the center of the Maxwell triangle in most other colorimetric computations at the Bureau of Standards. 
The Optical Society of America extrapolated excitations, as published, are weighted on the basis of an energy distribution of equal value at all wave lengths. On the form ${ }^{14}$ shown in Figure 12 these excitation values have been multiplied, wave length by wave length, by the mean-sun relative energy data and the resulting values further

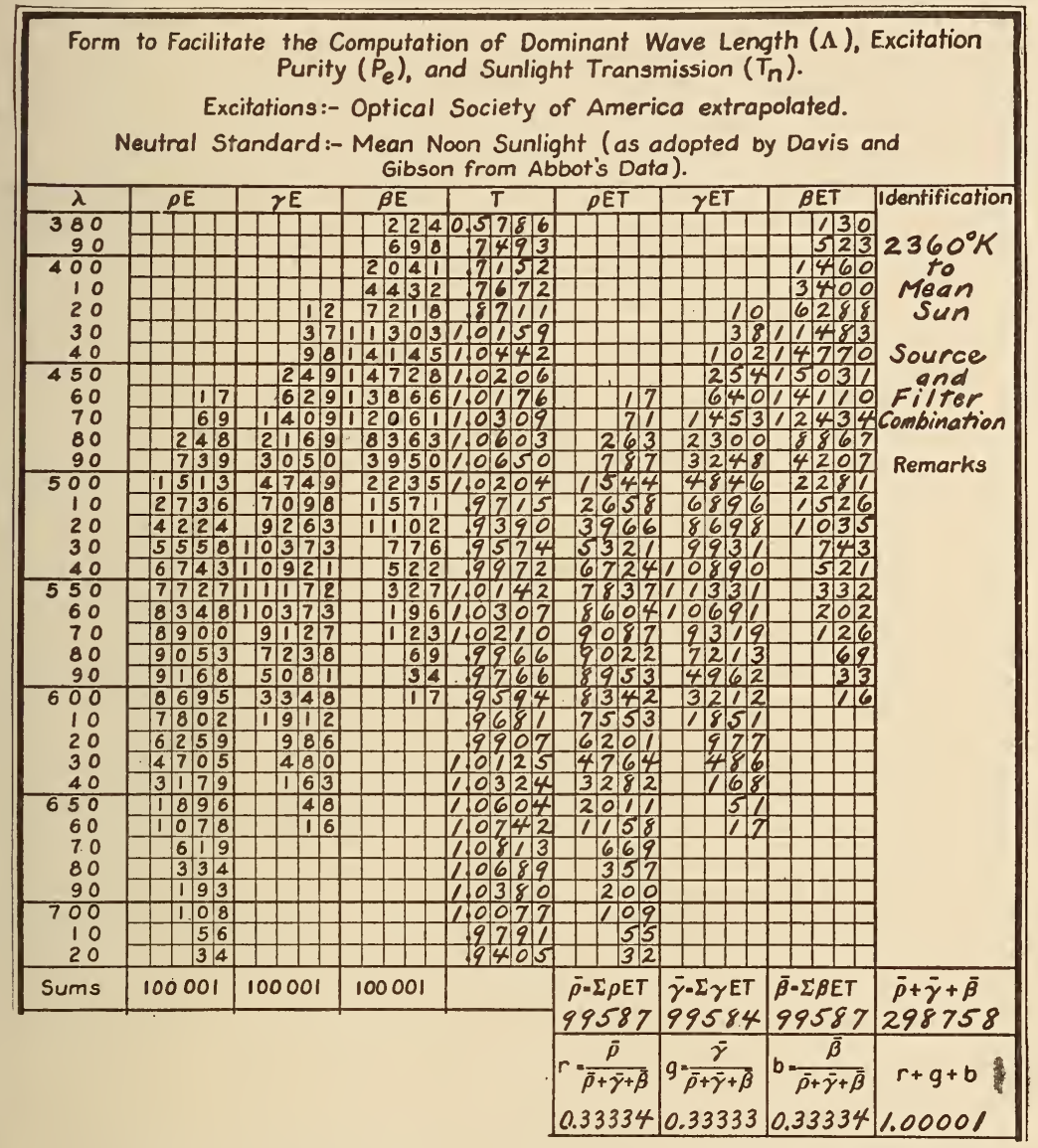

Figure 12.-Computation of $r, g$, and $b$ for the $2,360^{\circ} K$.-to-mean-sun filter

In column headed $T$ are given values of the ratio $\frac{T_{\mathrm{filter}} E_{2,360}}{E^{\prime}}=\frac{E^{\prime \prime}}{E^{\prime}}$

where, as a function of wave length, $T_{\text {filter }}$ is the transmission of the filter, $E_{2,360}$ is the energy distribution for $2,360^{\circ} \mathrm{K}$., and $E^{\prime}$ is the energy distribution of mean sun, the "neutral" stimulus. The values of $\frac{E^{\prime \prime}}{E^{\prime}}$ are taken from the last column of Table 9 , and are as given in chart 2 (with one less significant figure). (It should be noted that values of $r, g$, and $b$, computed on the basis of mean sun, $E^{\prime}$, as the "neutral" stimulus will, in general, be slightly different from those computed on the basis of Abbot-Priest sun (see fig. 3))

adjusted, respectively, by three factors so chosen that the three sums give the same total. These adjusted values are given in Figure 12 in the columns headed $\rho E, \gamma E$, and $\beta E$, totaling to 100,000 each.

14 To facilitate the computations a form designed by Priest with Abbot-Priest sunlight as the "neutral", stimulus was revised by Davis using the adopted mean sunlight as the "neutral" stimulus. Part of this form thus revised is shown in Figure 12. 
If the specification of the color of a glass were to be computed on the basis of mean sun as the "neutral" stimulus, its spectral transmission would be entered in the column headed $T$. If the color corresponding to an energy distribution (such as a lamp-and-filter combination) is to be specified, the ratios of that energy distribution to mean sun must be obtained, wave length by wave length. As an example, this ratio in the case of the $2,360^{\circ} \mathrm{K}$.-to-mean-sun filter is shown tabulated in Figure 12, under column $T$. These values are the same as the values of $E^{\prime \prime} / E^{\prime}$ given in chart 2, except that they are carried to an additional decimal place.

The products $\rho E T, \gamma E T$, and $\beta E T$ were then computed as illustrated and the respective sums $\bar{\rho}, \bar{\gamma}, \bar{\beta}$ were then taken, $\bar{\rho}+\bar{\gamma}+\bar{\beta}$ obtained, and the trilinear coordinates $(r, g, b)$ computed, all as illustrated in Figure 12. In the case of mean sun, $r, g$, and $b$ are each, by definition, exactly equal to one-third.

The first step in changing the energy distribution of any particular source-and-filter combination so that its color should agree with that of the adopted mean sun was to compute the $r, g$, and $b$ values for this energy distribution as shown in Figure 12. In general, although the spectral energy distribution of the source-and-filter combination had been adjusted to as close an agreement with that of mean sun as was possible by the method outlined in the preceding section, the values of $r, g$, and $b$ so obtained were not exactly 0.33333 . The next step thereupon was to make still further adjustment, in all cases small, of one or more of the concentrations of the ingredients until the values of $r, g$, and $b$ for the source-and-filter combination differed from 0.33333 by less than 0.00006 .

These final adjustments were facilitated by plotting the $r-b$ coordinates to a large scale near the "neutral" point. It was soon found that changes in the concentration of any one of the three components always shifted the point on the diagram along a certain direction and by an amount practically proportional to the change in concentration. After a little experience it was usually possible to obtain the final desired values with three or four trials.

In addition to choosing concentrations which would give correct values of $r, g$, and $b$, a further restriction was made, viz, that when these concentrations, for the respective $A, B_{1}$ and $B_{2}$ components, were plotted against color temperature they must fall upon smooth curves, so that values of concentrations for any intermediate temperature read from such curves would fit within the series.

As finally adopted, values of concentrations were obtained which gave (1) correct values of $r, g$, and $b$, viz, 0.3333, (2) smooth curves when plotted against color temperatures, and (3) energy distributions as illustrated in the charts. This was done at every $100^{\circ} \mathrm{K}$. from $2,300^{\circ}$ to $4,000^{\circ} \mathrm{K}$., besides $2,360^{\circ}$ and $2,848^{\circ} \mathrm{K}$. These values of concentration are given in Table 8 , the values at intermediate color temperatures being obtained from the concentration curves by interpolation.

A detailed example of the computation of $E^{\prime \prime}$ and $E^{\prime \prime} / E^{\prime}$ is given in Table 9 , which is self-explanatory. The $2,360^{\circ} \mathrm{K}$-to-mean-sun filter (chart 2) was chosen for this purpose. The data shown are for the respective concentrations as finally determined, giving values (fig. 12) of $r, g, b=0.3333$. The same laborious computation had to be carried through at each set of trial concentrations in order to get 
values of $E^{\prime \prime} / E^{\prime}$ for the trial computations of $r, g$, and $b$. A procedure similar to that herein described was carried out for all of the 38 filters illustrated in the charts.

TABLE 8.-Concentrations and light transmissions of filters of Series I, 2,300 $4,000^{\circ} K$. to mean noon sunlight ${ }^{1}$

\begin{tabular}{|c|c|c|c|c|c|c|c|c|c|}
\hline $\begin{array}{l}\text { Color } \\
\text { tempera- } \\
\text { ture }\left({ }^{\circ} \mathrm{K} .\right) \\
\text { of source }\end{array}$ & $\begin{array}{c}\text { Grams of } \\
\text { copper } \\
\text { sulphate } \\
\text { and } \\
\text { grams of } \\
\text { mannite } \\
\text { per liter } \\
\text { in solu- } \\
\text { tion A }\end{array}$ & $\begin{array}{c}\text { Grams of } \\
\text { cobalt } \\
\text { ammo- } \\
\text { nium } \\
\text { sulphate } \\
\text { per liter } \\
\text { in solu- } \\
\text { tion B }\end{array}$ & $\begin{array}{c}\text { Grams of } \\
\text { copper } \\
\text { sulphate } \\
\text { per liter } \\
\text { in solu- } \\
\text { tion B }\end{array}$ & $\begin{array}{c}\text { Light } \\
\text { trans- } \\
\text { mission }\end{array}$ & $\begin{array}{c}\text { Color } \\
\text { tempera- } \\
\text { ture }\left({ }^{\circ} \mathrm{K} .\right) \\
\text { of source }\end{array}$ & $\begin{array}{l}\text { Grams of } \\
\text { copper } \\
\text { sulphate } \\
\text { and } \\
\text { grams of } \\
\text { mannite } \\
\text { per liter } \\
\text { in solu- } \\
\text { tion A }\end{array}$ & $\begin{array}{l}\text { Grams of } \\
\text { cobalt } \\
\text { ammo- } \\
\text { nium } \\
\text { sulphate } \\
\text { per liter } \\
\text { in solu- } \\
\text { tion B }\end{array}$ & $\begin{array}{l}\text { Grams of } \\
\text { copper } \\
\text { sulphate } \\
\text { per liter } \\
\text { in solu- } \\
\text { tion B }\end{array}$ & $\begin{array}{l}\text { Light } \\
\text { trans- } \\
\text { mission }\end{array}$ \\
\hline $\begin{array}{l}2.300 \\
2,320 \ldots \\
2,340 \\
2,360 \\
2,380\end{array}$ & $\begin{array}{l}3.901 \\
3.835 \\
3.770 \\
3.707 \\
3.644\end{array}$ & $\begin{array}{l}28.300 \\
27.80 \\
27.31 \\
26.827 \\
26.35\end{array}$ & $\begin{array}{l}28.250 \\
27.90 \\
27.54 \\
27.180 \\
26.83\end{array}$ & $\begin{array}{l}0.1224 \\
.1266 \\
.1309 \\
.1352 \\
.1397\end{array}$ & $\begin{array}{l}3,200_{\ldots} \\
3,220_{-.} \\
3,240_{-} \\
3,260_{-} \\
3,280_{-.}\end{array}$ & $\begin{array}{l}1.784 \\
1.751 \\
1.719 \\
1.687 \\
1.655\end{array}$ & $\begin{array}{c}10.890 \\
10.60 \\
10.32 \\
10.03 \\
9.75\end{array}$ & $\begin{array}{l}14.570 \\
14.34 \\
14.11 \\
13.88 \\
13.66\end{array}$ & $\begin{array}{l}.370 \\
.377 \\
.383 \\
.390 \\
.397\end{array}$ \\
\hline $\begin{array}{l}2,420 \ldots \\
2,440 \ldots \\
2,460 \ldots \\
2,480 \ldots\end{array}$ & $\begin{array}{l}\text { 3. } 582 \\
3.522 \\
3.463 \\
3.405 \\
3.348\end{array}$ & $\begin{array}{l}25.870 \\
25.40 \\
24.94 \\
24.49 \\
24.04\end{array}$ & $\begin{array}{l}26.480 \\
26.13 \\
25.78 \\
25.43 \\
25.08\end{array}$ & $\begin{array}{l}.1442 \\
.1487 \\
.153 \\
.158 \\
.163\end{array}$ & $\begin{array}{l}3,300_{\ldots} \\
3,320_{\ldots} \\
3,340_{\ldots-} \\
3,360_{\ldots} \\
3,380_{\ldots}\end{array}$ & $\begin{array}{l}1.624 \\
1.594 \\
1.564 \\
1.534 \\
1.504\end{array}$ & $\begin{array}{l}9.470 \\
9.19 \\
8.92 \\
8.64 \\
8.37\end{array}$ & $\begin{array}{l}13.430 \\
13.21 \\
12.99 \\
12.77 \\
12.55\end{array}$ & $\begin{array}{l}.403 \\
.410 \\
.417 \\
.423 \\
.430\end{array}$ \\
\hline $\begin{array}{l}2,500 \ldots \\
2,520 \ldots \\
2,540 \ldots \\
2,560 \ldots \\
2,580 \ldots\end{array}$ & $\begin{array}{l}3.292 \\
3.237 \\
3.183 \\
3.128 \\
3.076\end{array}$ & $\begin{array}{l}23.590 \\
23.14 \\
22.70 \\
22.27 \\
21.83\end{array}$ & $\begin{array}{l}24.730 \\
24.38 \\
24.04 \\
23.69 \\
23.34\end{array}$ & $\begin{array}{l}.168 \\
.173 \\
.177 \\
.183 \\
.188\end{array}$ & $\begin{array}{l}3,400 \ldots \\
3,420 \\
3,440 \\
3,460 \\
3,480\end{array}$ & $\begin{array}{l}1.475 \\
1.446 \\
1.417 \\
1.388 \\
1.360\end{array}$ & $\begin{array}{l}8.100 \\
7.83 \\
7.57 \\
7.31 \\
7.05\end{array}$ & $\begin{array}{l}12.330 \\
12.11 \\
11.90 \\
11.68 \\
11.47\end{array}$ & $\begin{array}{l}.437 \\
.444 \\
.451 \\
.457 \\
.464\end{array}$ \\
\hline $\begin{array}{l}2,600 \\
2,620 \\
2,640 \\
2,660 \\
2,680\end{array}$ & $\begin{array}{l}3.024 \\
2.973 \\
2.923 \\
2.874 \\
2.825\end{array}$ & $\begin{array}{l}21.400 \\
20.97 \\
20.56 \\
20.14 \\
19.73\end{array}$ & $\begin{array}{l}23.000 \\
22.66 \\
22.32 \\
21.98 \\
21.64\end{array}$ & $\begin{array}{l}.193 \\
.198 \\
.203 \\
.209 \\
.214\end{array}$ & $\begin{array}{l}3,500_{--} \\
3,520_{--} \\
3,540_{--} \\
3,560_{--} \\
3,580_{--}\end{array}$ & $\begin{array}{l}1.332 \\
1.305 \\
1.278 \\
1.251 \\
1.225\end{array}$ & $\begin{array}{l}6.790 \\
6.53 \\
6.29 \\
6.05 \\
5.81\end{array}$ & $\begin{array}{l}11.260 \\
11.05 \\
10.84 \\
10.64 \\
10.43\end{array}$ & $\begin{array}{l}.471 \\
.478 \\
.485 \\
.492 \\
.499\end{array}$ \\
\hline $\begin{array}{l}2,700 \\
2,720 \\
2,740 \\
2,760 \\
2,780\end{array}$ & $\begin{array}{l}2.777 \\
2.730 \\
2.684 \\
2.639 \\
2.595\end{array}$ & $\begin{array}{l}19.325 \\
18.92 \\
18.54 \\
18.16 \\
17.78\end{array}$ & $\begin{array}{l}21.300 \\
20.97 \\
20.64 \\
20.33 \\
20.02\end{array}$ & $\begin{array}{l}.220 \\
.225 \\
.231 \\
.236 \\
.242\end{array}$ & $\begin{array}{l}3,600 \ldots \\
3,620 \ldots \\
3,640 \ldots \\
3,660_{--} \\
3,680_{--}\end{array}$ & $\begin{array}{l}1.199 \\
1.173 \\
1.148 \\
1.123 \\
1.098\end{array}$ & $\begin{array}{l}5.570 \\
5.33 \\
5.09 \\
4.85 \\
4.61\end{array}$ & $\begin{array}{c}10.220 \\
10.02 \\
9.82 \\
9.62 \\
9.42\end{array}$ & $\begin{array}{l}.506 \\
.513 \\
.520 \\
.527 \\
.534\end{array}$ \\
\hline $\begin{array}{l}2,800 \\
2,820 \ldots \\
2,840 \\
2,860 \\
2,880\end{array}$ & $\begin{array}{l}2.551 \\
2.507 \\
2.464 \\
2.421 \\
2.379\end{array}$ & $\begin{array}{l}17.400 \\
17.02 \\
16.66 \\
16.30 \\
15.94\end{array}$ & $\begin{array}{l}19.720 \\
19.44 \\
19.15 \\
18.86 \\
18.58\end{array}$ & $\begin{array}{l}.248 \\
.253 \\
.259 \\
.265 \\
.271\end{array}$ & $\begin{array}{l}3,700 \\
3,720 \\
3,740 \\
3,760 \\
3,780\end{array}$ & $\begin{array}{r}1.074 \\
1.050 \\
1.026 \\
1.002 \\
.978\end{array}$ & $\begin{array}{l}4.380 \\
4.15 \\
3.92 \\
3.70 \\
3.48\end{array}$ & $\begin{array}{l}9.210 \\
9.02 \\
8.81 \\
8.61 \\
8.41\end{array}$ & $\begin{array}{l}.541 \\
.548 \\
.556 \\
.563 \\
.570\end{array}$ \\
\hline $\begin{array}{l}2,900 \ldots \\
2,920 \ldots \\
2,940 \ldots \\
2,960 \ldots \\
2,980- \\
\end{array}$ & $\begin{array}{l}2.337 \\
2.296 \\
2.256 \\
2.217 \\
2.178\end{array}$ & $\begin{array}{l}15.580 \\
15.23 \\
14.89 \\
14.56 \\
14.23\end{array}$ & $\begin{array}{l}18.300 \\
18.03 \\
17.77 \\
17.51 \\
17.25\end{array}$ & $\begin{array}{l}.277 \\
.283 \\
.289 \\
.295 \\
.301\end{array}$ & $\begin{array}{l}3,800 \ldots \\
3,820-- \\
3,840 \ldots \\
3,860 \ldots- \\
3,880 \ldots\end{array}$ & $\begin{array}{l}.955 \\
.932 \\
.910 \\
.888 \\
.866\end{array}$ & $\begin{array}{l}3.260 \\
3.04 \\
2.82 \\
2.60 \\
2.39\end{array}$ & $\begin{array}{l}8.210 \\
8.01 \\
7.82 \\
7.62 \\
7.42\end{array}$ & $\begin{array}{l}.577 \\
.584 \\
.592 \\
.599 \\
.606\end{array}$ \\
\hline $\begin{array}{l}3,000 \\
3,020 \\
3,040 \\
3,060 \\
3,080\end{array}$ & $\begin{array}{l}2.140 \\
2.102 \\
2.065 \\
2.028 \\
1.992\end{array}$ & $\begin{array}{l}13.900 \\
13.58 \\
13.27 \\
12.97 \\
12.66\end{array}$ & $\begin{array}{l}17.000 \\
16.74 \\
16.49 \\
16.24 \\
16.00\end{array}$ & $\begin{array}{l}.307 \\
.313 \\
.320 \\
.326 \\
.332\end{array}$ & $\begin{array}{l}3,900 \\
3,920 \\
3,940 \\
3,960 \\
3,980\end{array}$ & $\begin{array}{l}.845 \\
.824 \\
.803 \\
.782 \\
.761\end{array}$ & $\begin{array}{l}2.175 \\
1.96 \\
1.75 \\
1.54 \\
1.34\end{array}$ & $\begin{array}{l}7.220 \\
7.03 \\
6.83 \\
6.64 \\
6.45\end{array}$ & $\begin{array}{l}.613 \\
.620 \\
.628 \\
.635 \\
.642\end{array}$ \\
\hline $\begin{array}{l}3,100 \ldots \\
3,120 \ldots \\
3,140 \ldots \\
3,160 \ldots \\
3,180 \ldots\end{array}$ & $\begin{array}{l}1.956 \\
1.921 \\
1.886 \\
1.851 \\
1.817\end{array}$ & $\begin{array}{l}12.360 \\
12.06 \\
11.76 \\
11.47 \\
11.18\end{array}$ & $\begin{array}{l}15.760 \\
15.51 \\
15.27 \\
15.04 \\
14.80\end{array}$ & $\begin{array}{l}.338 \\
.335 \\
.351 \\
.357 \\
.364\end{array}$ & 2,848 & 2.445 & 16.520 & 19.020 & $\begin{array}{r}.649 \\
.262\end{array}$ \\
\hline
\end{tabular}

1 Spectrophotometric illustrations are given in charts 1 to 20 ; methods of computation are described in Section V, 4; details of preparation are given in Section IX. 


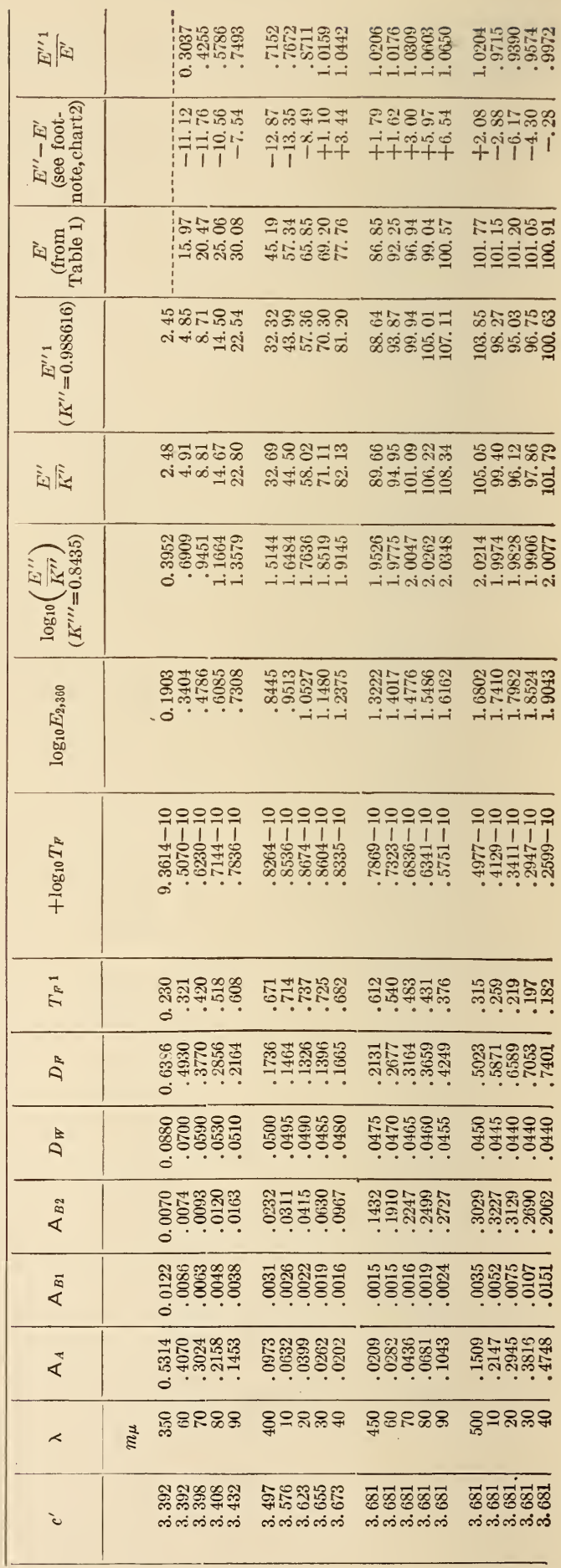




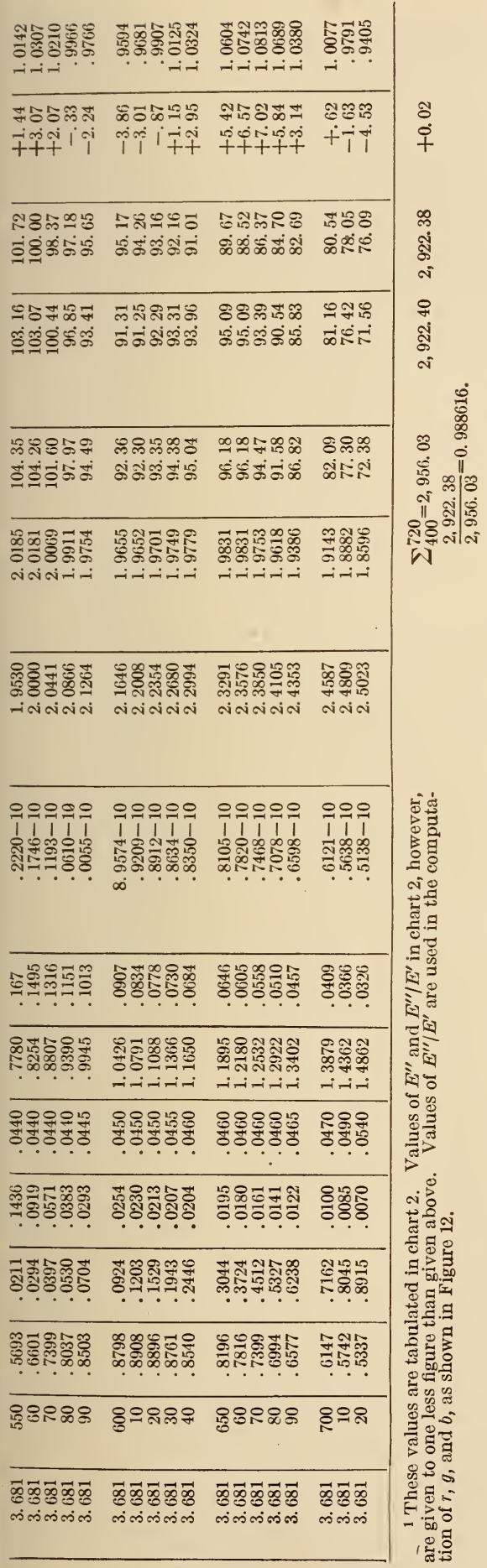


The complete computation of a filter is a long process and the chances for error are, of course, correspondingly large. To avoid any reasonable possibility of such errors, even though computing machines

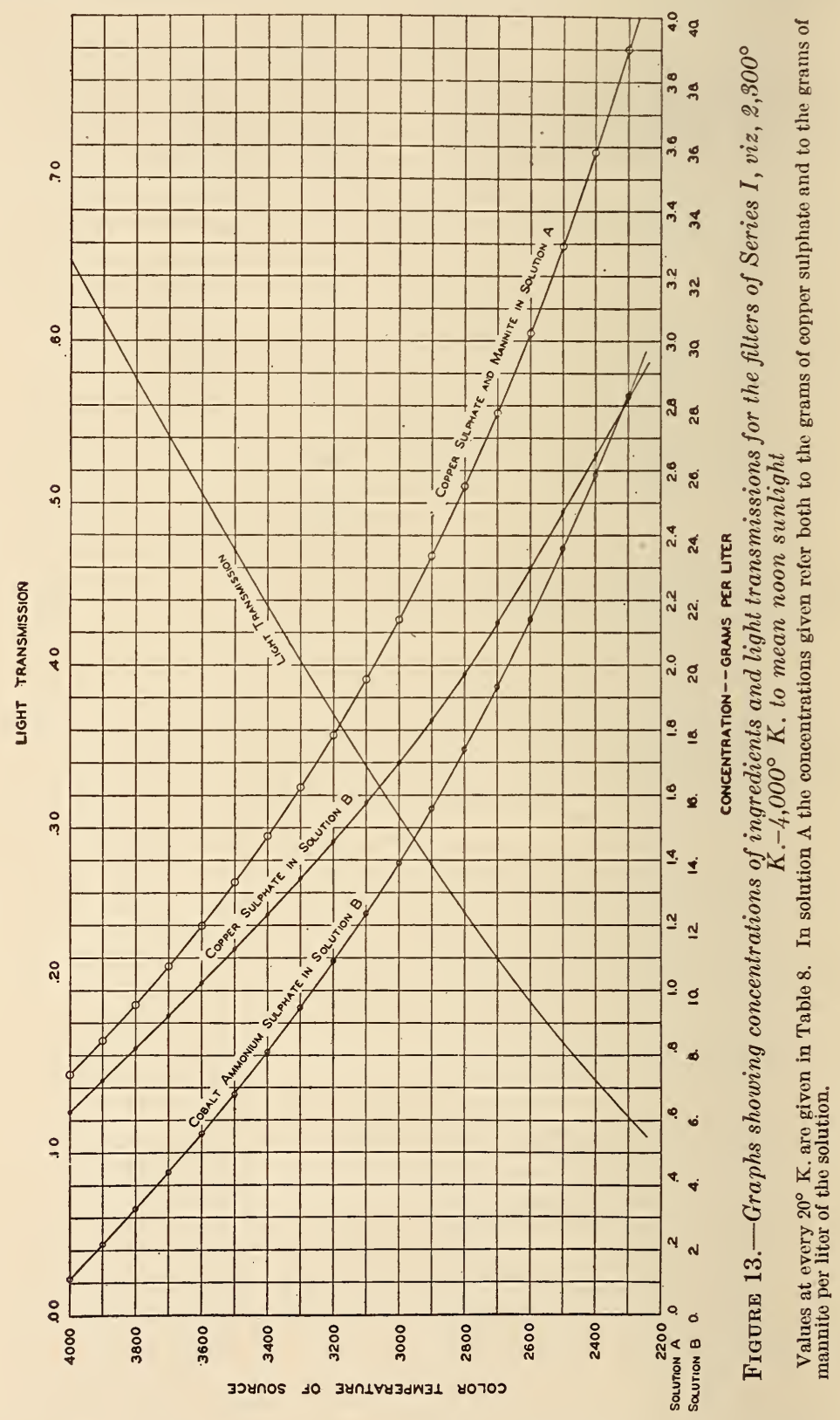

were used in all computations, complete independent recomputations were made on each filter, starting with the fundamental spectrophotometric data. 
The filters of Series I are described and illustrated in charts 1 to 20, inclusive, and in Table 8 and Figure 13.

\section{(c) TO COMPUTE LIGHT TRANSMISSION OF FILTERS}

It is customary in photographic sensitometry to specify the intensity of the light source in terms of visual candlepower. If the light used is obtained from a source-and-filter combination, it is essential (in accord with this custom) to know the effective candlepower of this source-and-filter combination. If the transmission of the filter for the light given by the source is known, the candlepower of the combination may be obtained by multiplying the candlepower of the source by the transmission of the filter. The transmissions of the filters are also of interest in their applications to colorimetry.

The light transmission of the filters may, of course, be obtained directly by photometric measurements, as, for example, by the flicker method. However, in the case of colored filters the results may be influenced by the photometric field size and brightness and may also vary from one observer to another because of the different values of relative visibility possessed even by observers of normal color sense.

This difficulty may be avoided by computing the light transmission from the spectral transmission, using standard visibility data. The values of light transmission so obtained should, for the present type of filters, be practically identical with the values that would be obtained if the light transmissions had been directly measured under standard photometric conditions by a large number of observers and averaged.

The light transmissions for the present filters have been computed by the following formula:

$$
T_{o}=\frac{\sum_{400}^{720}{ }_{\left(E_{\theta} V T\right)}}{\sum_{400}^{720}{ }_{\left(E_{\theta} V\right)}}
$$

The summations were carried out using values at every $10 \mathrm{~m} \mu$ from $400 \mathrm{~m} \mu$ to $720 \mathrm{~m} \mu$. In the formula $\theta$ refers to the color temperature of the light source, this varying from $2,300^{\circ}$ to $4,000^{\circ} \mathrm{K}$. $T_{\theta}$ is the light transmission of the filter for a $\theta^{\circ} \mathrm{K}$. source, $T$ is the spectral transmission tabulated on the charts, $E_{\theta}$ is the relative energy for $\theta^{\circ} \mathrm{K}$. as given in Table 2 , and $V$ is the relative visibility function as given in Table 10. These values of relative visibility are those recommended by Gibson and Tyndall $(11,12)$ and adopted by the International Commission on Illumination (10) and by the American Engineering Standards Committee and by the Illuminating Engineering Society (38).

The visibility data in Table 10 are given from $400 \mathrm{~m} \mu$ to $760 \mathrm{~m} \mu$ while the spectral range used to compute the light transmission of the filters does not go above $720 \mathrm{~m} \mu$. It was found by trial that excluding values of $T, E_{\theta}$, and $V$ above $720 \mathrm{~m} \mu$ caused an error so small (not more than 0.00003 in the light transmission of any of the filters) that they could be safely omitted. 
Values of light transmission for the various filters of Series I thus computed are given on the charts and in Table 8 and illustrated in Figure 13. Computations were carried out at the same color temperatures as used for the colorimetric computations. The intermediate values of Table 8 were obtained by plotting the computed values against color temperature and reading the desired values from this curve.

TABLE 10.-Standard values of the relative visibility of radiani energy

\begin{tabular}{|c|c|c|c|}
\hline Wave length in millimicrons & $\begin{array}{c}\text { Relative } \\
\text { visibility } 1\end{array}$ & Wave length in millimicrons & $\begin{array}{c}\text { Relative } \\
\text { visibility }\end{array}$ \\
\hline $\begin{array}{l}400 \\
410 \\
430 \\
440\end{array}$ & $\begin{array}{l}0.0004 \\
.0012 \\
.0040 \\
.0116 \\
.023\end{array}$ & $\begin{array}{l}600 \\
610 \\
620 \\
630\end{array}$ & $\begin{array}{l}0.631 \\
.503 \\
.381 \\
.265 \\
.175\end{array}$ \\
\hline $\begin{array}{l}450-(40-10-10-1 \\
480 \\
490\end{array}$ & $\begin{array}{l}.038 \\
.060 \\
.091 \\
.139 \\
.208\end{array}$ & $\begin{array}{l}650 \\
660 \\
670 \\
680 \\
690 \\
690\end{array}$ & $\begin{array}{l}.107 \\
.061 \\
.032 \\
.017 \\
.0082\end{array}$ \\
\hline $\begin{array}{l}500 \\
510 \\
520 \\
540\end{array}$ & $\begin{array}{l}.323 \\
.503 \\
.710 \\
.862 \\
.954\end{array}$ & 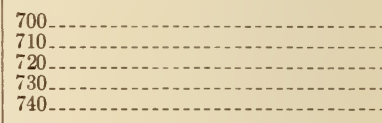 & $\begin{array}{l}.0041 \\
.0021 \\
.00105 \\
.00052 \\
.00025\end{array}$ \\
\hline $\begin{array}{l}550 \\
560 \\
570 \\
580 \\
590\end{array}$ & $\begin{array}{l}.995 \\
.995 \\
.952 \\
.870 \\
.757\end{array}$ & $\begin{array}{l}750-10 \\
760\end{array}$ & .00012 \\
\hline
\end{tabular}

1 These values were recommended by Gibson and Tyndall (B. S. Sci. Paper No. 475, p. 174; 1923; Trans. 1. E. S., 19, pp. 192-193; 1924; Proc., International Commission on 1llumination, sixth meeting, 1924, p. 235). They have been adopted as standard by the lnternational Commission on Illumination (Proc., p. 67 , sixth meeting) and by the American Engineering Standards Committee and the llluminating Engineering Society (Trans. 1. E. S, 20, pp. 629, 632; 1925).

\section{DESIGN OF FILTERS OF SERIES II $-2,848^{\circ}$ TO $3,500^{\circ}-10,000^{\circ} \mathrm{K}$.}

Because of the general interest in high color temperatures in the fields of colorimetry and astronomy and the limited means available for the reproduction of high color temperatures in the laboratory, it has seemed desirable to develop this second series of filters, in this case starting at a fixed lower color temperature of $2,848^{\circ} \mathrm{K}$. By means of this series of filters, radiant energy evoking the color of a Planckian radiator at any temperature between $3,500^{\circ}$ and $10,000^{\circ} \mathrm{K}$. may be readily obtained in the laboratory. The particular starting point, $2,848^{\circ} \mathrm{K}$. was chosen for the filters of Series II for the reason that it happens to be the color temperature of a certain primary standard lamp and thus came to be a common reference point. This particular color temperature is a very suitable one at which to operate gas-filled lamps.

Before proceeding with the computations for the filters of Series II, values of $r, g$, and $b$ had to be computed for all the black-body temperatures between $3,500^{\circ}$ and $10,000^{\circ} \mathrm{K}$. for which filters were to be specifically designed. This was done and values of $r, g$, and $b$ obtained as given in Table 11 and illustrated in Figure 14. (A similar illustration for color temperatures from $2,000^{\circ}$ to $4,000^{\circ} \mathrm{K}$. is given in the next section.) 
After designing these filters for what seemed to be the best energy match, the colorimetric computations were carried out, striving now to make the values of $r, g$, and $b$ not equal to 0.33333 , as was the case

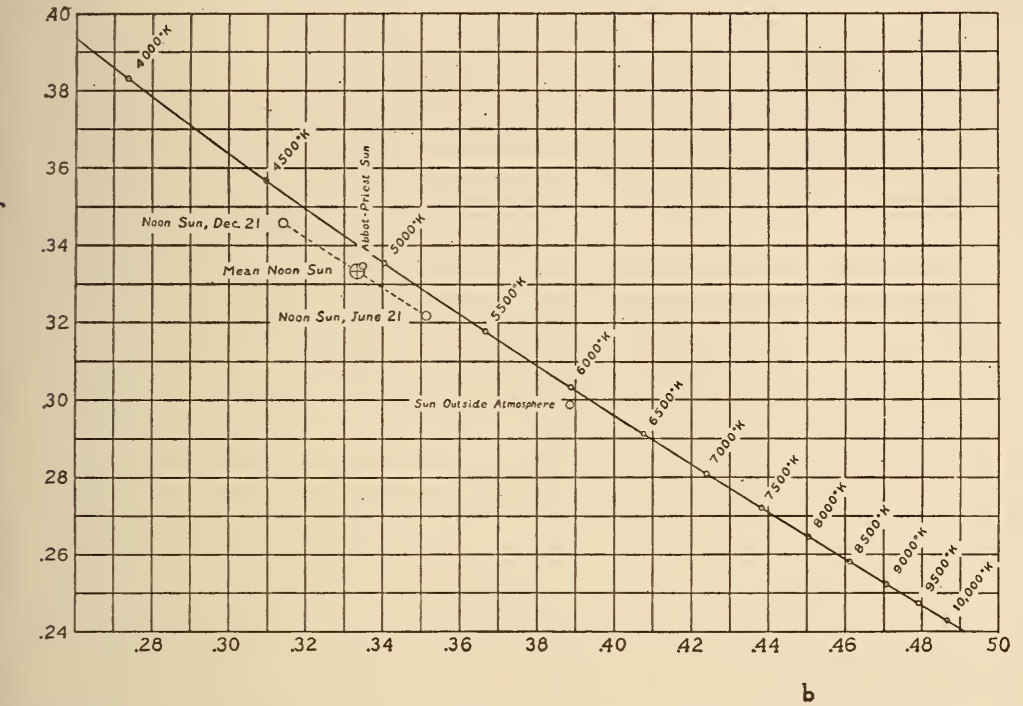

FIGURE 14.-Section of the $r-b$ diagram showing colorimetric positions of various phases of sunlight relative to the black-body locus

(See fig. 16 for temperatures between $2,000^{\circ} \mathrm{K}$. and $4,000^{\circ} \mathrm{K}$.) Values of $r, g$, and $b$ are given in Table 11 , for every $20^{\circ} \mathrm{K}$. up to $8,000^{\circ} \mathrm{K}$. and for every $100^{\circ} \mathrm{K}$. above that. All values of $\tau, g$, and $b$ are computed on the basis of mean noon sunlight as the "neutral" stimulus.

with the filters of Series I, but equal to the respective values given in Table 11 for the particular color temperatures involved.

TABLE 11.-Trilinear coordinates $(r, g, b)$ of colors evoked by black-body radiant energy as a function of color temperature

\begin{tabular}{|c|c|c|c|c|c|c|c|}
\hline \multirow{2}{*}{$\begin{array}{c}\text { Color } \\
\text { temperature } 1\end{array}$} & \multicolumn{3}{|c|}{ Trilinear coordinates ${ }^{2}$} & \multirow{2}{*}{$\begin{array}{c}\text { Color } \\
\text { temperature }\end{array}$} & \multicolumn{3}{|c|}{ Trilinear coordinates ${ }^{2}$} \\
\hline & $r$ & $g$ & $b$ & & $r$ & $g$ & $b$ \\
\hline $\begin{array}{l}{ }^{\circ} K . \\
1,600 \\
1,610 \\
1,620 \\
1,630 \\
1,640\end{array}$ & $\begin{array}{l}0.64249 \\
.6407 \\
.6358 \\
.6369 \\
.6352\end{array}$ & $\begin{array}{l}0.32033 \\
.3214 \\
.3224 \\
.3235 \\
.3245\end{array}$ & $\begin{array}{l}0.03718 \\
.0379 \\
.0388 \\
.0397 \\
.0404\end{array}$ & $\begin{array}{l}{ }^{\circ} K . \\
1,750 \ldots \\
1,760 \\
1,770 \ldots \\
1,780 \ldots \\
1,790 \ldots\end{array}$ & $\begin{array}{r}0.6157 \\
.6139 \\
.6123 \\
.6106 \\
.6089\end{array}$ & $\begin{array}{l}0.3343 \\
.3352 \\
.3359 \\
.3367 \\
.3374\end{array}$ & $\begin{array}{l}0.0499 \\
.0508 \\
.0518 \\
.0527 \\
.0536\end{array}$ \\
\hline $\begin{array}{l}1,650 \\
1,660 \\
1,670 \\
1,680 \\
1,690\end{array}$ & $\begin{array}{l}.6333 \\
.6315 \\
.6297 \\
.6279 \\
.6262\end{array}$ & $\begin{array}{l}.3255 \\
.3264 \\
.3274 \\
.3283 \\
.3292\end{array}$ & $\begin{array}{l}.0413 \\
.0422 \\
.0430 \\
.0438 \\
.0447\end{array}$ & $\begin{array}{l}1,800 \\
1,810 \\
1,820 \\
1,830 \\
1,840\end{array}$ & $\begin{array}{l}.60725 \\
.6056 \\
.6039 \\
.6023 \\
.6007\end{array}$ & $\begin{array}{l}.33815 \\
.3388 \\
.3396 \\
.3403 \\
.3409\end{array}$ & $\begin{array}{l}.05460 \\
.0555 \\
.0564 \\
.0573 \\
.0583\end{array}$ \\
\hline $\begin{array}{l}1,700 \\
1,710 \\
1,720 \\
1,730 \\
1,740\end{array}$ & $\begin{array}{l}.62435 \\
.6226 \\
.6209 \\
.6192 \\
.6173\end{array}$ & $\begin{array}{l}.33010 \\
.3309 \\
.3318 \\
.3327 \\
.3336\end{array}$ & $\begin{array}{l}.04555 \\
.0464 \\
.0473 \\
.0482 \\
.0491\end{array}$ & $\begin{array}{l}1,850 \\
1,860 \\
1,870 \\
1,880 \\
1,890\end{array}$ & $\begin{array}{l}.5991 \\
.5974 \\
.5958 \\
.5943 \\
.5927\end{array}$ & $\begin{array}{l}.3416 \\
.3422 \\
.3428 \\
.3434 \\
.3441\end{array}$ & $\begin{array}{l}.0593 \\
.0603 \\
.0613 \\
.0622 \\
.0632\end{array}$ \\
\hline
\end{tabular}

$1 C_{2}=14,350$ micron-degrees. See Table 2.

2 "Neutral" stimulus: Mean sun as adopted in this investigation. Excitations: O. S. A. extrapolated (J. O. S. A. and R. S. I., 10, p. 230; 1925). Computed values are given to five significant figures; other values, to four significant figures, were read from large scale graph plotted from computed values. 
TABLE 11.-Trilinear coordinates $(r, g, b)$ of colors evoked by black-body radiant energy as a function of color temperature-Continued

\begin{tabular}{|c|c|c|c|c|c|c|c|}
\hline \multirow{2}{*}{$\begin{array}{c}\text { Color } \\
\text { temperature }\end{array}$} & \multicolumn{3}{|c|}{ Trilinear coordinates ${ }^{2}$} & \multirow{2}{*}{$\begin{array}{l}\text { Color } \\
\text { temperature } 1\end{array}$} & \multicolumn{3}{|c|}{ Trilinear coordinates ${ }^{2}$} \\
\hline & $r$ & $g$ & $b$ & & $r$ & $g$ & $b$ \\
\hline $\begin{array}{l}{ }^{\circ} K \\
1,900 \\
1,910 \\
1,920 \\
1,930 \\
1,940\end{array}$ & $\begin{array}{l}0.59108 \\
.5895 \\
.5879 \\
.5864 \\
.5848\end{array}$ & $\begin{array}{l}0.34470 \\
.3452 \\
.3458 \\
.3464 \\
.3469\end{array}$ & $\begin{array}{l}0.06422 \\
.0652 \\
.0662 \\
.0672 \\
.0682\end{array}$ & $\begin{array}{l}{ }^{\circ} K . \\
3,100 \\
3,120 \\
3,140 \\
3,160 \ldots \\
3,180\end{array}$ & $\begin{array}{r}0.4480 \\
.4463 \\
.4446 \\
.4429 \\
.4411\end{array}$ & $\begin{array}{l}9.3592 \\
.3589 \\
.3587 \\
.3584 \\
.3581\end{array}$ & $\begin{array}{l}0.1927 \\
.1947 \\
.1967 \\
.1987 \\
.2007\end{array}$ \\
\hline $\begin{array}{l}1,950 \ldots 0 \\
1,960 \\
1,970 \\
1,990\end{array}$ & $\begin{array}{l}.5833 \\
.5818 \\
.5802 \\
.5787 \\
.5772\end{array}$ & $\begin{array}{l}.3475 \\
.3480 \\
.3486 \\
.3491 \\
.3495\end{array}$ & $\begin{array}{l}.0692 \\
.0702 \\
.0712 \\
.0722 \\
.0733\end{array}$ & $\begin{array}{l}3,200 \ldots \\
3,220-\ldots \\
3,240 \ldots \\
3,260- \\
3,280-\end{array}$ & $\begin{array}{l}.4394 \\
.4377 \\
.4360 \\
.4344 \\
.4328\end{array}$ & $\begin{array}{l}.3578 \\
.3575 \\
.3572 \\
.3569 \\
.3566\end{array}$ & $\begin{array}{l}.2027 \\
.2047 \\
.2067 \\
.2086 \\
.2106\end{array}$ \\
\hline $\begin{array}{l}2,000 \ldots \\
2,020 \ldots \\
2,040-. \\
2,060-\ldots \\
2,080_{-}\end{array}$ & $\begin{array}{l}.57571 \\
.5727 \\
.5697 \\
.5668 \\
.5639\end{array}$ & $\begin{array}{l}.34998 \\
.3509 \\
.3518 \\
.3526 \\
.3534\end{array}$ & $\begin{array}{l}.07431 \\
.0764 \\
.0785 \\
.0806 \\
.0827\end{array}$ & $\begin{array}{l}3,300 \ldots \\
3,320 \ldots \\
3,340- \\
3,360 \ldots \\
3,380_{-}\end{array}$ & $\begin{array}{l}.4312 \\
.4297 \\
.4281 \\
.4265 \\
.4249\end{array}$ & $\begin{array}{l}.3563 \\
.3560 \\
.3557 \\
.3553 \\
.3550\end{array}$ & $\begin{array}{l}.2125 \\
.2144 \\
.2163 \\
.2182 \\
.2201\end{array}$ \\
\hline $\begin{array}{l}2,100 \\
2,120 \ldots \\
2,140 \\
2,160 \\
2,180\end{array}$ & $\begin{array}{l}.56101 \\
.5582 \\
.5554 \\
.5526 \\
.5499\end{array}$ & $\begin{array}{l}.35416 \\
.3549 \\
.3555 \\
.3562 \\
.3568\end{array}$ & $\begin{array}{l}.08483 \\
.0870 \\
.0891 \\
.0912 \\
.0934\end{array}$ & $\begin{array}{l}3,400 \ldots \\
3,420 \ldots \\
3,440 \ldots \\
3,460 \ldots \\
3,480 \ldots\end{array}$ & $\begin{array}{l}.4234 \\
.4219 \\
.4203 \\
.4188 \\
.4173\end{array}$ & $\begin{array}{r}.3546 \\
.3543 \\
.3540 \\
.3537 \\
.3533\end{array}$ & $\begin{array}{l}.2220 \\
.2239 \\
.2258 \\
.2276 \\
.2294\end{array}$ \\
\hline $\begin{array}{l}2,200 \ldots- \\
2,220 \ldots \\
2,240 \ldots \\
2,260 \ldots \\
2,280 \ldots\end{array}$ & $\begin{array}{l}.54716 \\
.5445 \\
.5418 \\
.5391 \\
.5365\end{array}$ & $\begin{array}{l}.35727 \\
.3578 \\
.3583 \\
.3588 \\
.3592\end{array}$ & $\begin{array}{l}.09556 \\
.0978 \\
.1000 \\
.1021 \\
.1033\end{array}$ & $\begin{array}{l}3,500-- \\
3,520- \\
3,540_{-} \\
3,560_{-} \\
3,580_{--}\end{array}$ & $\begin{array}{l}.41592 \\
.4145 \\
.4130 \\
.4116 \\
.4101\end{array}$ & $\begin{array}{l}.35290 \\
.3525 \\
.3522 \\
.3518 \\
.3514\end{array}$ & $\begin{array}{l}.23118 \\
.2331 \\
.2349 \\
.2367 \\
.2385\end{array}$ \\
\hline $\begin{array}{l}2,300 \ldots \\
2,320 \ldots \\
2,340 \ldots \\
2,360 \ldots \\
2,380 \ldots\end{array}$ & $\begin{array}{l}.5339 \\
.5314 \\
.5288 \\
.52631 \\
.5238\end{array}$ & $\begin{array}{l}.3596 \\
.3599 \\
.3603 \\
.36063 \\
.3609\end{array}$ & $\begin{array}{l}.1065 \\
.1087 \\
.1109 \\
.11306 \\
.1153\end{array}$ & $\begin{array}{l}3,600- \\
3,620- \\
3,640- \\
3,660- \\
3,680_{-}-\end{array}$ & $\begin{array}{l}.4087 \\
.4074 \\
.4060 \\
.4046 \\
.4033\end{array}$ & $\begin{array}{l}.3510 \\
.3506 \\
.3502 \\
.3498 \\
.3495\end{array}$ & $\begin{array}{l}.2403 \\
.2421 \\
.2438 \\
.2456 \\
.2473\end{array}$ \\
\hline $\begin{array}{l}2,400 \ldots \\
2,420 \ldots \\
2,440 \ldots \\
2,460 \ldots \\
2,480 \ldots\end{array}$ & $\begin{array}{l}.52133 \\
.5189 \\
.5164 \\
.5141 \\
.5117\end{array}$ & $\begin{array}{l}.36117 \\
.3614 \\
.3616 \\
.3618 \\
.3620\end{array}$ & $\begin{array}{l}.11750 \\
.1198 \\
.1220 \\
.1242 \\
.1264\end{array}$ & $\begin{array}{l}3,700 \ldots \\
3,720 \ldots \\
3,740 \ldots \\
3,760 \ldots \\
3,780 \ldots\end{array}$ & $\begin{array}{l}.4019 \\
.4006 \\
.3993 \\
.3980 \\
.3967\end{array}$ & $\begin{array}{l}.3491 \\
.3488 \\
.3484 \\
.3480 \\
.3476\end{array}$ & $\begin{array}{l}.2490 \\
.2507 \\
.2524 \\
.2541 \\
.2558\end{array}$ \\
\hline $\begin{array}{l}2,500 \ldots \\
2,520 \ldots \\
2,540 \ldots \\
2,560 \ldots \\
2,580 \ldots\end{array}$ & $\begin{array}{l}.50936 \\
.5070 \\
.5047 \\
.5024 \\
.5001\end{array}$ & $\begin{array}{l}.36217 \\
.3622 \\
.3623 \\
.3624 \\
.3625\end{array}$ & $\begin{array}{l}.12847 \\
.1308 \\
.1330 \\
.1352 \\
.1374\end{array}$ & $\begin{array}{l}3,800_{-} \\
3,820_{-} \\
3,840_{\ldots} \\
3,860_{-} \\
3,880_{-}\end{array}$ & $\begin{array}{l}.3954 \\
.3941 \\
.3928 \\
.3916 \\
.3903\end{array}$ & $\begin{array}{l}.3472 \\
.3468 \\
.3464 \\
.3460 \\
.3456\end{array}$ & $\begin{array}{l}.2575 \\
.2591 \\
.2608 \\
.2624 \\
.2641\end{array}$ \\
\hline $\begin{array}{l}2,600 \\
2,620 \\
2,640 \\
2,660\end{array}$ & $\begin{array}{l}.49788 \\
.4956 \\
.4934 \\
.4912 \\
.4890\end{array}$ & $\begin{array}{l}.36259 \\
.3627 \\
.3627 \\
.3627 \\
.3627\end{array}$ & $\begin{array}{l}.13953 \\
.1417 \\
.1439 \\
.1461 \\
.1483\end{array}$ & $\begin{array}{l}3,900 \ldots \\
3,920 \ldots \\
3,940 \\
3,960 \\
3,980\end{array}$ & $\begin{array}{l}.3891 \\
.3879 \\
.3867 \\
.3855 \\
.3843\end{array}$ & $\begin{array}{l}.3452 \\
.3448 \\
.3444 \\
.3440 \\
.3437\end{array}$ & $\begin{array}{l}.2657 \\
.2673 \\
.2689 \\
.2704 \\
.2720\end{array}$ \\
\hline $\begin{array}{l}2,700 \ldots \\
2,720 \ldots \\
2,740 \ldots \\
2,760 \ldots \\
2,780 \ldots\end{array}$ & $\begin{array}{l}.48690 \\
.4848 \\
.4827 \\
.4806 \\
.4786\end{array}$ & $\begin{array}{l}.36260 \\
.3625 \\
.3624 \\
.3623 \\
.3622\end{array}$ & $\begin{array}{l}.15050 \\
.1527 \\
.1549 \\
.1571 \\
.1592\end{array}$ & $\begin{array}{l}4,000 \\
4,020 \ldots \\
4,040 \ldots \\
4,060 \ldots \\
4,080\end{array}$ & $\begin{array}{l}.38313 \\
.3819 \\
.3808 \\
.3797 \\
.3785\end{array}$ & $\begin{array}{l}.34332 \\
.3429 \\
.3425 \\
.3421 \\
.3417\end{array}$ & $\begin{array}{l}.27356 \\
.2752 \\
.2767 \\
.2782 \\
.2787\end{array}$ \\
\hline $\begin{array}{l}2,800 \\
2,820 \\
2,840 \\
2,860\end{array}$ & $\begin{array}{l}.47657 \\
.4745 \\
.4725 \\
.4705 \\
.4685\end{array}$ & $\begin{array}{l}.36218 \\
.3620 \\
.3619 \\
.3617 \\
.3616\end{array}$ & $\begin{array}{l}.16125 \\
.1635 \\
.1656 \\
.1678 \\
.1699\end{array}$ & $\begin{array}{l}4,100 \\
4,120 \\
4,140 \\
4,160 \\
4,180\end{array}$ & $\begin{array}{l}.3774 \\
.3763 \\
.3752 \\
.3741 \\
.3730\end{array}$ & $\begin{array}{l}.3413 \\
.3409 \\
.3405 \\
.3401 \\
.3398\end{array}$ & $\begin{array}{l}.2812 \\
.2827 \\
.2842 \\
.2857 \\
.2872\end{array}$ \\
\hline $\begin{array}{l}2,900 \\
2,920 \\
2,940 \\
2,960 \\
2,980\end{array}$ & $\begin{array}{l}.46659 \\
.4646 \\
.4628 \\
.4609 \\
.4590\end{array}$ & $\begin{array}{l}.36143 \\
.3612 \\
.3610 \\
.3608 \\
.3606\end{array}$ & $\begin{array}{l}.17198 \\
.1741 \\
.1762 \\
.1783 \\
.1804\end{array}$ & $\begin{array}{l}4,200 \\
4,220 \\
4,240 \\
4,260 \\
4,280\end{array}$ & $\begin{array}{l}.3719 \\
.3708 \\
.3698 \\
.3687 \\
.3677\end{array}$ & $\begin{array}{l}.3394 \\
.3390 \\
.3386 \\
.3382 \\
.3378\end{array}$ & $\begin{array}{l}.2887 \\
.2901 \\
.2916 \\
.2930 \\
.2945\end{array}$ \\
\hline $\begin{array}{l}3,000 \\
3,020 \\
3,040 \\
3,060 \\
3,080\end{array}$ & $\begin{array}{l}.45716 \\
.4553 \\
.4534 \\
.4516 \\
.4498\end{array}$ & $\begin{array}{l}.36044 \\
.3601 \\
.3599 \\
.3597 \\
.3594\end{array}$ & $\begin{array}{l}.18240 \\
.1845 \\
.1866 \\
.1887 \\
.1907\end{array}$ & $\begin{array}{l}4,300 \ldots \\
4,320 \ldots \\
4,340 \ldots \\
4,360 \ldots \\
4,380 \ldots\end{array}$ & $\begin{array}{l}.3667 \\
.3656 \\
.3645 \\
.3635 \\
.3625\end{array}$ & $\begin{array}{l}.3374 \\
.3370 \\
.3367 \\
.3363 \\
.3359\end{array}$ & $\begin{array}{l}.2959 \\
.2973 \\
.2987 \\
.3001 \\
.3015\end{array}$ \\
\hline
\end{tabular}

1,2 See footnotes 1 and 2, p. 55. 
TABLE 11.-Trilinear coordinates $(r, g, b)$ of colors evoked by black. body radiant energy as a function of color iemperature-Continued

\begin{tabular}{|c|c|c|c|c|c|c|c|}
\hline \multirow{2}{*}{$\begin{array}{l}\text { Color } \\
\text { temperature }\end{array}$} & \multicolumn{3}{|c|}{ Trilinear coordinates ${ }^{2}$} & \multirow{2}{*}{$\begin{array}{l}\text { Color } \\
\text { temperature } 1\end{array}$} & \multicolumn{3}{|c|}{ Trilinear coordinates 2} \\
\hline & $r$ & $g$ & $b$ & & $r$ & $g$ & $b$ \\
\hline $\begin{array}{l}{ }^{\circ} K . \\
4,400 \\
4,420 \\
4,440 \\
4,460 \\
4,480\end{array}$ & $\begin{array}{r}0.3615 \\
.3605 \\
.3596 \\
.3586 \\
.3576\end{array}$ & $\begin{array}{r}0.3355 \\
.3351 \\
.3347 \\
.3343 \\
.3339\end{array}$ & $\begin{array}{r}0.3029 \\
.3043 \\
.3056 \\
.3070 \\
.3084\end{array}$ & $\begin{array}{l}{ }^{\circ} K . \\
5,700 \\
5,720 \\
5,740 \\
5,760 \\
5,780\end{array}$ & $\begin{array}{r}0.3118 \\
.3112 \\
.3106 \\
.3100 \\
.3094\end{array}$ & $\begin{array}{r}0.3125 \\
.3122 \\
.3119 \\
.3116 \\
.3112\end{array}$ & $\begin{array}{r}0.3757 \\
.3766 \\
.3775 \\
.3784 \\
.3793\end{array}$ \\
\hline $\begin{array}{l}4,500 \\
4,520 \\
4,540 \\
4,560\end{array}$ & $\begin{array}{l}.35675 \\
.3557 \\
.3548 \\
.3539 \\
.3530\end{array}$ & $\begin{array}{l}.33352 \\
.3332 \\
.3329 \\
.3325 \\
.3321\end{array}$ & $\begin{array}{l}.30973 \\
.3110 \\
.3123 \\
.3136 \\
.3149\end{array}$ & $\begin{array}{l}5,800 \\
5,820 \\
5,840 \\
5,860\end{array}$ & $\begin{array}{l}.3088 \\
.3083 \\
.3078 \\
.3072 \\
.3066\end{array}$ & $\begin{array}{r}.3109 \\
.3107 \\
.3103 \\
.3100 \\
.3097\end{array}$ & $\begin{array}{l}.3802 \\
.3811 \\
.3819 \\
.3828 \\
.3837\end{array}$ \\
\hline $\begin{array}{l}4,600 \\
4,620 \\
4,640 \\
4,660\end{array}$ & $\begin{array}{l}.3521 \\
.3512 \\
.3503 \\
.3494 \\
.3485\end{array}$ & $\begin{array}{l}.3317 \\
.3313 \\
.3309 \\
.3305 \\
.3302\end{array}$ & $\begin{array}{r}.3162 \\
.3175 \\
.3188 \\
.3201 \\
.3214\end{array}$ & $\begin{array}{l}5,900 \\
5,920 \\
5,940 \\
5,960\end{array}$ & $\begin{array}{l}.3061 \\
.3056 \\
.3050 \\
.3044 \\
.3039\end{array}$ & $\begin{array}{l}.3094 \\
.3092 \\
.3089 \\
.3086 \\
.3083\end{array}$ & $\begin{array}{r}.3845 \\
.3853 \\
.3862 \\
.3870 \\
.3878\end{array}$ \\
\hline $\begin{array}{l}4,700 \\
4,720 \\
4,740 \\
4,760 \\
4,780\end{array}$ & $\begin{array}{r}.3476 \\
.3468 \\
.3459 \\
.3451 \\
.3443\end{array}$ & $\begin{array}{l}.3298 \\
.3294 \\
.3290 \\
.3286 \\
.3282\end{array}$ & $\begin{array}{l}.3226 \\
.3238 \\
.3251 \\
.3263 \\
.3275\end{array}$ & $\begin{array}{l}6,000 \\
6,020 \\
6,040 \\
6,060\end{array}$ & $\begin{array}{l}.30332 \\
.3028 \\
.3023 \\
.3018 \\
.3013\end{array}$ & $\begin{array}{l}.30801 \\
.3077 \\
.3074 \\
.3072 \\
.3069\end{array}$ & $\begin{array}{l}.38867 \\
.3895 \\
.3903 \\
.3911 \\
.3919\end{array}$ \\
\hline $\begin{array}{l}4,800 \\
4,820 \\
4,840 \\
4,860\end{array}$ & $\begin{array}{l}.3434 \\
.3426 \\
.3418 \\
.3410 \\
.3401\end{array}$ & $\begin{array}{l}.3278 \\
.3274 \\
.3271 \\
.3268 \\
.3264\end{array}$ & $\begin{array}{l}.3287 \\
.3299 \\
.3311 \\
.3323 \\
.3335\end{array}$ & $\begin{array}{l}6,100 \\
6,120 \\
6,140 \\
6,160\end{array}$ & $\begin{array}{l}.3008 \\
.3002 \\
.2997 \\
.2992 \\
.2987\end{array}$ & $\begin{array}{l}.3066 \\
.3063 \\
.3060 \\
.3057 \\
.3054\end{array}$ & $\begin{array}{l}.3927 \\
.3935 \\
.3942 \\
.3950 \\
.3958\end{array}$ \\
\hline $\begin{array}{l}4,900 \\
4,920 \\
4,940 \\
4,960 \\
4,980\end{array}$ & $\begin{array}{l}.3393 \\
.3386 \\
.3378 \\
.3370 \\
.3362\end{array}$ & $\begin{array}{l}.3260 \\
.3257 \\
.3253 \\
.3249 \\
.3246\end{array}$ & $\begin{array}{l}.3347 \\
.3358 \\
.3370 \\
.3382 \\
.3393\end{array}$ & $\begin{array}{l}6,200 \\
6,220 \\
6,240 \\
6,260 \\
6,280\end{array}$ & $\begin{array}{l}.2982 \\
.2977 \\
.2972 \\
.2968 \\
.2963\end{array}$ & $\begin{array}{l}.3052 \\
.3049 \\
.3046 \\
.3043 \\
.3041\end{array}$ & $\begin{array}{l}.3966 \\
.3973 \\
.3981 \\
.3988 \\
.3996\end{array}$ \\
\hline $\begin{array}{l}5,000 \\
5,020 \\
5,040 \\
5,060\end{array}$ & $\begin{array}{l}.33543 \\
.3346 \\
.3339 \\
.3331 \\
.3324\end{array}$ & $\begin{array}{l}.32419 \\
.3238 \\
.3235 \\
.3231 \\
.3228\end{array}$ & $\begin{array}{l}.34038 \\
.3416 \\
.3427 \\
.3438 \\
.3449\end{array}$ & $\begin{array}{l}6,300 \\
6,320 \\
6,340 \\
6,360\end{array}$ & $\begin{array}{r}.2958 \\
.2953 \\
.2949 \\
.2944 \\
.2939\end{array}$ & $\begin{array}{l}.3038 \\
.3035 \\
.3032 \\
.3030 \\
.3027\end{array}$ & $\begin{array}{r}.4003 \\
.4011 \\
.4018 \\
.4026 \\
.4033\end{array}$ \\
\hline $\begin{array}{l}5,100 \\
5,120 \\
5,140 \\
5,160\end{array}$ & $\begin{array}{l}.3316 \\
.3309 \\
.3301 \\
.3294 \\
.3287\end{array}$ & $\begin{array}{l}.3224 \\
.3220 \\
.3217 \\
.3213 \\
.3210\end{array}$ & $\begin{array}{l}.3460 \\
.3471 \\
.3482 \\
.3493 \\
.3503\end{array}$ & $\begin{array}{l}6,400 \\
6,420 \\
6,440 \\
6,460\end{array}$ & $\begin{array}{r}.2935 \\
.2930 \\
.2926 \\
.2921 \\
.2917\end{array}$ & $\begin{array}{l}.3024 \\
.3022 \\
.3019 \\
.3017 \\
.3014\end{array}$ & $\begin{array}{l}.4040 \\
.4047 \\
.4054 \\
.4062 \\
.4069\end{array}$ \\
\hline $\begin{array}{l}5,200 \\
5,220 \\
5,240 \\
5,260\end{array}$ & $\begin{array}{l}.3280 \\
.3273 \\
.3265 \\
.3258 \\
.3252\end{array}$ & $\begin{array}{l}.3207 \\
.3203 \\
.3200 \\
.3197 \\
.3193\end{array}$ & $\begin{array}{l}.3514 \\
.3525 \\
.3535 \\
.3546 \\
.3556\end{array}$ & $\begin{array}{l}6,500 \\
6,520 \\
6,540 \\
6,560\end{array}$ & $\begin{array}{l}.29117 \\
.2908 \\
.2903 \\
.2899 \\
.2895\end{array}$ & $\begin{array}{l}.30124 \\
.3009 \\
.3007 \\
.3004 \\
.3002\end{array}$ & $\begin{array}{l}.40759 \\
.4083 \\
.4089 \\
.4096 \\
.4103\end{array}$ \\
\hline $\begin{array}{l}5,300 \\
5,320 \\
5,340 \\
5,360\end{array}$ & $\begin{array}{l}.3245 \\
.3238 \\
.3231 \\
.3224 \\
.3218\end{array}$ & $\begin{array}{r}.3189 \\
.3186 \\
.3183 \\
.3179 \\
.3176\end{array}$ & $\begin{array}{l}.3567 \\
.3577 \\
.3587 \\
.3597 \\
.3607\end{array}$ & $\begin{array}{l}6,600 \\
6,620 \\
6,640 \\
6,660\end{array}$ & $\begin{array}{r}.2890 \\
.2886 \\
.2882 \\
.2877 \\
.2873\end{array}$ & $\begin{array}{l}.2999 \\
.2997 \\
.2994 \\
.2992 \\
.2990\end{array}$ & $\begin{array}{r}.4110 \\
.4117 \\
.4123 \\
.4130 \\
.4137\end{array}$ \\
\hline $\begin{array}{l}5,400 \\
5,420 \\
5,440 \\
5,460\end{array}$ & $\begin{array}{l}.3211 \\
.3204 \\
.3198 \\
.3192 \\
.3185\end{array}$ & $\begin{array}{l}.3173 \\
.3169 \\
.3166 \\
.3163 \\
.3160\end{array}$ & $\begin{array}{l}.3617 \\
.3627 \\
.3636 \\
.3645 \\
.3655\end{array}$ & $\begin{array}{l}6,700 \\
6,720 \\
6,740 \\
6,760 \\
6,780\end{array}$ & $\begin{array}{l}.2869 \\
.2865 \\
.2861 \\
.2857 \\
.2853\end{array}$ & $\begin{array}{r}.2988 \\
.2985 \\
.2982 \\
.2980 \\
.2978\end{array}$ & $\begin{array}{l}.4143 \\
.4150 \\
.4157 \\
.4163 \\
.4169\end{array}$ \\
\hline $\begin{array}{l}5,500 \\
5,520 \\
5,540 \\
5,560\end{array}$ & $\begin{array}{l}.31788 \\
.3173 \\
.3167 \\
.3160 \\
.3154\end{array}$ & $\begin{array}{l}.31566 \\
.3153 \\
.3150 \\
.3147 \\
.3143\end{array}$ & $\begin{array}{l}.36647 \\
.3674 \\
.3684 \\
.3693 \\
.3702\end{array}$ & $\begin{array}{l}6,800 \\
6,820 \\
6,840 \\
6,860 \\
6,880\end{array}$ & $\begin{array}{l}.2849 \\
.2844 \\
.2840 \\
.2836 \\
.2832\end{array}$ & $\begin{array}{r}.2975 \\
.2972 \\
.2970 \\
.2968 \\
.2966\end{array}$ & $\begin{array}{l}.4176 \\
.4183 \\
.4189 \\
.4195 \\
.4202\end{array}$ \\
\hline $\begin{array}{l}5,600 \\
5,620 \\
5,640 \\
5,660\end{array}$ & $\begin{array}{l}.3148 \\
.3142 \\
.3136 \\
.3130 \\
.3124\end{array}$ & $\begin{array}{l}.3140 \\
.3137 \\
.3134 \\
.3131 \\
.3128\end{array}$ & $\begin{array}{r}.3712 \\
.3721 \\
.3730 \\
.3739 \\
.3748\end{array}$ & $\begin{array}{l}6,900 \\
6,920 \\
6,940 \\
6,960 \\
6,980\end{array}$ & $\begin{array}{r}.2828 \\
.2824 \\
.2820 \\
.2817 \\
.2813\end{array}$ & $\begin{array}{r}.2964 \\
.2961 \\
.2959 \\
.2957 \\
.2955\end{array}$ & $\begin{array}{l}.4208 \\
.4215 \\
.4221 \\
.4227 \\
.4233\end{array}$ \\
\hline
\end{tabular}

${ }^{1,2}$ See footnotes 1 and 2, p. 55 : 
TABLE 11.-Trilinear coordinates $(r, g, b)$ of colors evoked by black-body radiant energy as a function of color temperature-Continued

\begin{tabular}{|c|c|c|c|c|c|c|c|}
\hline \multirow{2}{*}{$\begin{array}{c}\text { Color } \\
\text { temperature }{ }^{1}\end{array}$} & \multicolumn{3}{|c|}{ Trilinear coordinates ${ }^{2}$} & \multirow{2}{*}{$\begin{array}{c}\text { Color } \\
\text { temperature } 1\end{array}$} & \multicolumn{3}{|c|}{ Trilinear coordinates ${ }^{2}$} \\
\hline & $r$ & $g$ & $b$ & & $r$ & $g$ & $b$ \\
\hline $\begin{array}{c}{ }^{\circ} \mathrm{K} . \\
7,000 \\
7,020 \\
7,040 \\
7,060 \\
7,080\end{array}$ & $\begin{array}{l}0.28086 \\
.2805 \\
.2801 \\
.2797 \\
.2793\end{array}$ & $\begin{array}{l}0.29520 \\
.2950 \\
.2948 \\
.2945 \\
.2943\end{array}$ & $\begin{array}{l}0.42394 \\
.4245 \\
.4252 \\
.4258 \\
.4264\end{array}$ & $\begin{array}{l}{ }^{\circ} K . \\
9,500 \\
9,600 \\
9,700 \\
9,800 \\
9,900 \\
\end{array}$ & $\begin{array}{r}0.2473 \\
.2463 \\
.2454 \\
.2445 \\
.2436\end{array}$ & $\begin{array}{r}0.2737 \\
.2730 \\
.2724 \\
.2718 \\
.2712\end{array}$ & $\begin{array}{r}0.4791 \\
.4807 \\
.4823 \\
.4848 \\
.4852\end{array}$ \\
\hline $\begin{array}{l}7,100 \ldots \\
7,120 \ldots \\
7,140 \ldots \\
7,160 \ldots \\
7,180_{-}\end{array}$ & $\begin{array}{l}.2790 \\
.2786 \\
.2782 \\
.2779 \\
.2775\end{array}$ & $\begin{array}{l}.2941 \\
.2939 \\
.2937 \\
.2934 \\
.2932\end{array}$ & $\begin{array}{l}.4270 \\
.4275 \\
.4281 \\
.4287 \\
.4293\end{array}$ & $\begin{array}{l}10,000 \\
10,100 \\
10,200 \\
10,300 \\
10,400\end{array}$ & $\begin{array}{l}.24277 \\
.2420 \\
.2412 \\
.2404 \\
.2397\end{array}$ & $\begin{array}{l}.27060 \\
.2700 \\
.2695 \\
.2690 \\
.2684\end{array}$ & $\begin{array}{l}.48663 \\
.4880 \\
.4894 \\
.4907 \\
.4920\end{array}$ \\
\hline $\begin{array}{l}7,200 \ldots- \\
7,220=- \\
7,240 \ldots \\
7,260- \\
7,280 \ldots\end{array}$ & $\begin{array}{l}.2771 \\
.2768 \\
.2764 \\
.2761 \\
.2758\end{array}$ & $\begin{array}{l}.2930 \\
.2928 \\
.2926 \\
.2923 \\
.2921\end{array}$ & $\begin{array}{l}.4299 \\
.4304 \\
.4310 \\
.4315 \\
.4321\end{array}$ & $\begin{array}{l}10,500-- \\
10,600_{--} \\
10,700-- \\
10,800_{-} \\
10,900_{-}\end{array}$ & $\begin{array}{l}.2389 \\
.2381 \\
.2374 \\
.2367 \\
.2360\end{array}$ & $\begin{array}{l}.2679 \\
.2674 \\
.2669 \\
.2664 \\
.2659\end{array}$ & $\begin{array}{l}.4932 \\
.4945 \\
.4957 \\
.4969 \\
.4981\end{array}$ \\
\hline $\begin{array}{l}7,300 \ldots \\
7,320 \ldots \\
7,340= \\
7,360 \ldots \\
7,380 \ldots\end{array}$ & $\begin{array}{l}.2754 \\
.2750 \\
.2747 \\
.2744 \\
.2740\end{array}$ & $\begin{array}{l}.2919 \\
.2917 \\
.2915 \\
.2913 \\
.2911\end{array}$ & $\begin{array}{l}.4327 \\
.4332 \\
.4338 \\
.4343 \\
.4349\end{array}$ & $\begin{array}{l}11,000-. \\
11,100= \\
11,200= \\
11,300_{--} \\
11,400_{-}\end{array}$ & $\begin{array}{l}.2353 \\
.2347 \\
.2340 \\
.2333 \\
.2327\end{array}$ & $\begin{array}{l}.2654 \\
.2649 \\
.2645 \\
.2640 \\
.2636\end{array}$ & $\begin{array}{l}.4993 \\
.5005 \\
.5016 \\
.5027 \\
.5038\end{array}$ \\
\hline $\begin{array}{l}7,400 \ldots \\
7,420 \ldots- \\
7,440 \ldots- \\
7,460 \ldots \\
7,480_{-}\end{array}$ & $\begin{array}{l}.2737 \\
.2733 \\
.2730 \\
.2727 \\
.2723\end{array}$ & $\begin{array}{l}.2909 \\
.2907 \\
.2904 \\
.2902 \\
.2900\end{array}$ & $\begin{array}{l}.4354 \\
.4360 \\
.4365 \\
.4371 \\
.4376\end{array}$ & $\begin{array}{l}11,500_{-} \\
11,600_{--} \\
11,700_{-} \\
11,800_{--} \\
11,900_{-}\end{array}$ & $\begin{array}{l}.2321 \\
.2314 \\
.2308 \\
.2302 \\
.2297\end{array}$ & $\begin{array}{l}.2631 \\
.2627 \\
.2623 \\
.2618 \\
.2614\end{array}$ & $\begin{array}{l}.5049 \\
.5059 \\
.5069 \\
.5079 \\
.5089\end{array}$ \\
\hline $\begin{array}{l}7,500 \ldots \\
7,520 \ldots \\
7,540 \ldots \\
7,560 \ldots \\
7,580 \ldots\end{array}$ & $\begin{array}{l}.2720 \\
.2717 \\
.2713 \\
.2710 \\
.2707\end{array}$ & $\begin{array}{l}.2898 \\
.2896 \\
.2894 \\
.2892 \\
.2890\end{array}$ & $\begin{array}{l}.4382 \\
.4387 \\
.4393 \\
.4398 \\
.4403\end{array}$ & $\begin{array}{l}12,000_{-} \\
12,100_{--} \\
12,200_{--} \\
12,300_{-} \\
12,400_{-}\end{array}$ & $\begin{array}{l}.22916 \\
.2286 \\
.2281 \\
.2276 \\
.2271\end{array}$ & $\begin{array}{l}.26097 \\
.2606 \\
.2602 \\
.2599 \\
.2595\end{array}$ & $\begin{array}{l}.50987 \\
.5107 \\
.5116 \\
.5125 \\
.5134\end{array}$ \\
\hline $\begin{array}{l}7,600 \ldots \\
7,620=- \\
7,640=- \\
7,660=- \\
7,680_{-}\end{array}$ & $\begin{array}{l}.2704 \\
.2701 \\
.2698 \\
.2695 \\
.2692\end{array}$ & $\begin{array}{l}.2888 \\
.2886 \\
.2884 \\
.2882 \\
.2880\end{array}$ & $\begin{array}{l}.4408 \\
.4412 \\
.4417 \\
.4422 \\
.4427\end{array}$ & $\begin{array}{l}12,500 \ldots \\
12,600 \ldots \\
12,700 \ldots \\
12,800_{-} \\
12,900_{-}\end{array}$ & $\begin{array}{l}.2266 \\
.2262 \\
.2257 \\
.2252 \\
.2248\end{array}$ & $\begin{array}{l}.2591 \\
.2588 \\
.2584 \\
.2581 \\
.2577\end{array}$ & $\begin{array}{l}.5142 \\
.5151 \\
.5159 \\
.5167 \\
.5175\end{array}$ \\
\hline $\begin{array}{l}7,700 \ldots \\
7,720 \ldots \\
7,740 \ldots \\
7,760= \\
7,780 \ldots\end{array}$ & $\begin{array}{l}.2689 \\
.2686 \\
.2683 \\
.2680 \\
.2677\end{array}$ & $\begin{array}{l}.2878 \\
.2876 \\
.2874 \\
.2872 \\
.2870\end{array}$ & $\begin{array}{l}.4432 \\
.4438 \\
.4443 \\
.4448 \\
.4453\end{array}$ & $\begin{array}{l}13,000 \\
13,100 \\
13,200 \\
13,300 \\
13,400\end{array}$ & $\begin{array}{l}.2243 \\
.2238 \\
.2234 \\
.2229 \\
.2225\end{array}$ & $\begin{array}{l}.2574 \\
.2571 \\
.2567 \\
.2564 \\
.2561\end{array}$ & $\begin{array}{l}.5183 \\
.5191 \\
.5198 \\
.5206 \\
.5213\end{array}$ \\
\hline $\begin{array}{l}7,800 \ldots \\
7,820 \ldots \\
7,840 \ldots \\
7,860 \ldots \\
7,880 \ldots\end{array}$ & $\begin{array}{l}.2674 \\
.2671 \\
.2668 \\
.2665 \\
.2662\end{array}$ & $\begin{array}{l}.2869 \\
.2867 \\
.2865 \\
.2863 \\
.2861\end{array}$ & $\begin{array}{l}.4458 \\
.4463 \\
.4468 \\
.4472 \\
.4477\end{array}$ & $\begin{array}{l}13,500 \ldots \\
13,600= \\
13,700 \ldots \\
13,800_{-} \\
13,900_{-}\end{array}$ & $\begin{array}{l}.2221 \\
.2217 \\
.2213 \\
.2209 \\
.2205\end{array}$ & $\begin{array}{l}.2558 \\
.2555 \\
.2552 \\
.2549 \\
.2546\end{array}$ & $\begin{array}{l}.5221 \\
.5228 \\
.5235 \\
.5242 \\
.5249\end{array}$ \\
\hline $\begin{array}{l}7,900 \ldots \\
7,920 \\
7,940 \\
7,960\end{array}$ & $\begin{array}{l}.2659 \\
.2656 \\
.2654 \\
.2651 \\
.2648\end{array}$ & $\begin{array}{l}.2859 \\
.2858 \\
.2856 \\
.2854 \\
.2852\end{array}$ & $\begin{array}{l}.4482 \\
.4487 \\
.4491 \\
.4495 \\
.4499\end{array}$ & $\begin{array}{l}14,000 \\
14,100 \\
14,200 \\
14,300 \\
14,400\end{array}$ & $\begin{array}{l}.22010 \\
.2197 \\
.2193 \\
.2190 \\
.2186\end{array}$ & $\begin{array}{l}.25432 \\
.2540 \\
.2537 \\
.2535 \\
.2532\end{array}$ & $\begin{array}{l}.52559 \\
.5262 \\
.5269 \\
.5275 \\
.5282\end{array}$ \\
\hline $\begin{array}{l}8,000 \ldots \\
8,100 \ldots \\
8,200 \\
8,300 \ldots \\
8,400 \ldots\end{array}$ & $\begin{array}{l}.26453 \\
.2631 \\
.2618 \\
.2605 \\
.2592\end{array}$ & $\begin{array}{l}.28508 \\
.2842 \\
.2833 \\
.2825 \\
.2817\end{array}$ & $\begin{array}{l}.45039 \\
.4527 \\
.4549 \\
.4571 \\
.4592\end{array}$ & $\begin{array}{l}14,500 \\
14,600 \\
14,700 \\
14,800 \\
14,900\end{array}$ & $\begin{array}{l}.2182 \\
.2179 \\
.2175 \\
.2172 \\
.2169\end{array}$ & $\begin{array}{l}.2529 \\
.2527 \\
.2524 \\
.2522 \\
.2519\end{array}$ & $\begin{array}{l}.5288 \\
.5294 \\
.5300 \\
.5306 \\
.5312\end{array}$ \\
\hline $\begin{array}{l}8,500 \\
8,600 \\
8,800 \\
8,900\end{array}$ & $\begin{array}{l}.2580 \\
.2568 \\
.2557 \\
.2545 \\
.2534\end{array}$ & $\begin{array}{l}.2809 \\
.2800 \\
.2793 \\
.2787 \\
.2779\end{array}$ & $\begin{array}{l}.4612 \\
.4632 \\
.4651 \\
.4669 \\
.4688\end{array}$ & $\begin{array}{l}15,000 \\
15,100 \\
15,200 \\
15,300 \\
15,400\end{array}$ & $\begin{array}{l}.2165 \\
.2162 \\
.2159 \\
.2156 \\
.2153\end{array}$ & $\begin{array}{l}.2517 \\
.2514 \\
.2512 \\
.2509 \\
.2507\end{array}$ & $\begin{array}{l}.5318 \\
.5323 \\
.5329 \\
.5334 \\
.5340\end{array}$ \\
\hline $\begin{array}{l}9,000 \\
9,100 \\
9,200 \\
9,300 \\
9,400\end{array}$ & $\begin{array}{l}.25225 \\
.2513 \\
.2502 \\
.2493 \\
.2483\end{array}$ & $\begin{array}{l}.27710 \\
.2764 \\
.2758 \\
.2751 \\
.2744\end{array}$ & $\begin{array}{l}.47065 \\
.4723 \\
.4740 \\
.4757 \\
.4774\end{array}$ & $\begin{array}{l}15,500-\ldots . \\
15,600-\cdots \\
15,700-\cdots \\
15,800-\cdots \\
15,900-\ldots \\
\end{array}$ & $\begin{array}{l}.2150 \\
.2147 \\
.2144 \\
.2141 \\
.2138\end{array}$ & $\begin{array}{l}.2505 \\
.2503 \\
.2500 \\
.2498 \\
.2496\end{array}$ & $\begin{array}{l}.5345 \\
.5350 \\
.5356 \\
.5361 \\
.5366\end{array}$ \\
\hline
\end{tabular}

1, 2 See footnotes 1 and 2, p. 55 . 
TABLE 11.-Trilinear coordinates $(r, g, b)$ of colors evoked by black-body radiant energy as a function of color temperature-Continued

\begin{tabular}{|c|c|c|c|c|c|c|c|}
\hline \multirow{2}{*}{$\begin{array}{c}\text { Color } \\
\text { temperature } 1\end{array}$} & \multicolumn{3}{|c|}{ Trilinear coordinates ${ }^{2}$} & \multirow{2}{*}{$\begin{array}{l}\text { Color } \\
\text { temperature } 1\end{array}$} & \multicolumn{3}{|c|}{ Trilinear coordinates ${ }^{2}$} \\
\hline & $r$ & $g$ & $b$ & & $r$ & $g$ & $b$ \\
\hline${ }^{\circ} \mathrm{K}$ & & & & ${ }^{\circ} \mathrm{K}$. & & & \\
\hline 16,000 & 0.21355 & 0.24938 & 0.53707 & $18,200 \ldots$ & 0.2083 & 0.2454 & 0.5463 \\
\hline $\begin{array}{l}16,100 \ldots \\
16,200 \ldots\end{array}$ & .2133 & .2492 & .5376 & $18,300 \ldots$ & .2081 & .2452 & .5466 \\
\hline & .2127 & .2488 & .5385 & & & & \\
\hline 16,400 & .2125 & .2486 & .5390 & 18,500 & .2077 & .2449 & .5473 \\
\hline 16,500 & .2122 & .2484 & .5395 & $\begin{array}{l}18,600- \\
18,700-\end{array}$ & .2073 & .2446 & .5480 \\
\hline & .2120 & .2482 & .5399 & $18,800_{--}$ & .2072 & .2445 & .5483 \\
\hline $\begin{array}{l}16,700 \\
16,800\end{array}$ & .2117 & .2480 & .5404 & $18,900 \ldots$ & .2070 & .2443 & .5487 \\
\hline $\begin{array}{l}16,800 \\
16,900\end{array}$ & .2115 & .2478 & $\begin{array}{r}.5408 \\
.5412\end{array}$ & 19,000 & 2068 & .2442 & .5490 \\
\hline 17,000 & 2110 & 2174 & .5417 & $19,100--$ & .2066 & .2441 & .5493 \\
\hline & .21107 & & .5121 & $19,300_{--}$ & .2062 & .2438 & .5499 \\
\hline 17,200 & .2105 & .2471 & .5425 & $19,400-$. & .2061 & .2436 & .5503 \\
\hline 17,300 & .2103 & .2469 & .5429 & & & & \\
\hline 17,400 & .2100 & .2467 & .5433 & $19,500 \ldots$ & .2059 & .2435 & .5506 \\
\hline $17,500 \ldots$ & 2098 & .2465 & .5437 & 19,70 & .2056 & $: .2432$ & $\begin{array}{l}.5509 \\
.5512\end{array}$ \\
\hline & .2096 & .2464 & .5441 & 19,800 & .2054 & .2431 & .5515 \\
\hline 17,700 & .2094 & .2462 & .5445 & $19,900 \ldots$ & .2052 & .2430 & .5518 \\
\hline 17,800 & .2092 & .2460 & .5448 & & & & \\
\hline 17,900 _ & .2090 & .2459 & .5452 & $20,000 \ldots$ & . 20507 & .24283 & .55210 \\
\hline $\begin{array}{l}18,000 \ldots \\
18.100\end{array}$ & $\begin{array}{l}.20873 \\
.2085\end{array}$ & $\begin{array}{l}.24571 \\
.2455\end{array}$ & $\begin{array}{l}.54556 \\
.5459\end{array}$ & $2,848 \ldots \ldots$ & .47172 & .36185 & . 16643 \\
\hline
\end{tabular}

1,2 See footnotes 1 and 2, p. 55 .

The methods of computation were the samo as outlined in Section $\mathrm{V}, 4$. The range of concentrations of the ingredients is about the same as was used in the mean-sun series, only the relative proportions are different. As just noted, each filter when combined with a blackbody energy distribution at $2,848^{\circ} \mathrm{K}$. gives by computation, an accurate color match with the respective high color temperature. A maximum deviation of but 0.00006 bctween the actual and desired values of $r, g$, and $b$ was obtained. However, the energy distributions obtained with this series do not, in goneral, match the ideal as well as in Series I, due to the high relative energies in the violet and ultraviolet in black-body color temperatures above $4,000^{\circ} \mathrm{K}$. (See chart 8 for $2,848^{\circ}$ to sunlight, Series I, and chart $24,2,848^{\circ}$ to $5,000^{\circ}$, Series II.) The deviations in the energy distributions may be noted on the charts. The light transmissions, computed in all cases for $2,848^{\circ} \mathrm{K}$., vary from 0.497 for the $3,500^{\circ} \mathrm{K}$. filter to 0.0989 for the $10,000^{\circ} \mathbf{K}$. filter.

Computations were thus carried out with filters designed (with $2,848^{\circ} \mathrm{K}$. source) to give $3,500^{\circ}, 4,000^{\circ}, 4,500^{\circ}, 5,000^{\circ}, 5,500^{\circ}$, $6,000^{\circ}, 6,500^{\circ}, 7,000^{\circ}, 8,000^{\circ}, 9,000^{\circ}$, and $10,000^{\circ} \mathrm{K}$. These computations gave values of concentration and transmission which, when plotted against color temperature, gave smooth, regular curves from which intermediate values were obtained as was done for Series I. Likewise, as before, complete independent recomputations were made on all the filters.

The filters of Series II are described and illustrated in charts 21 to 31 , inclusive, and in Table 12 and Figure 15.

$$
13416^{\circ}-31-5
$$




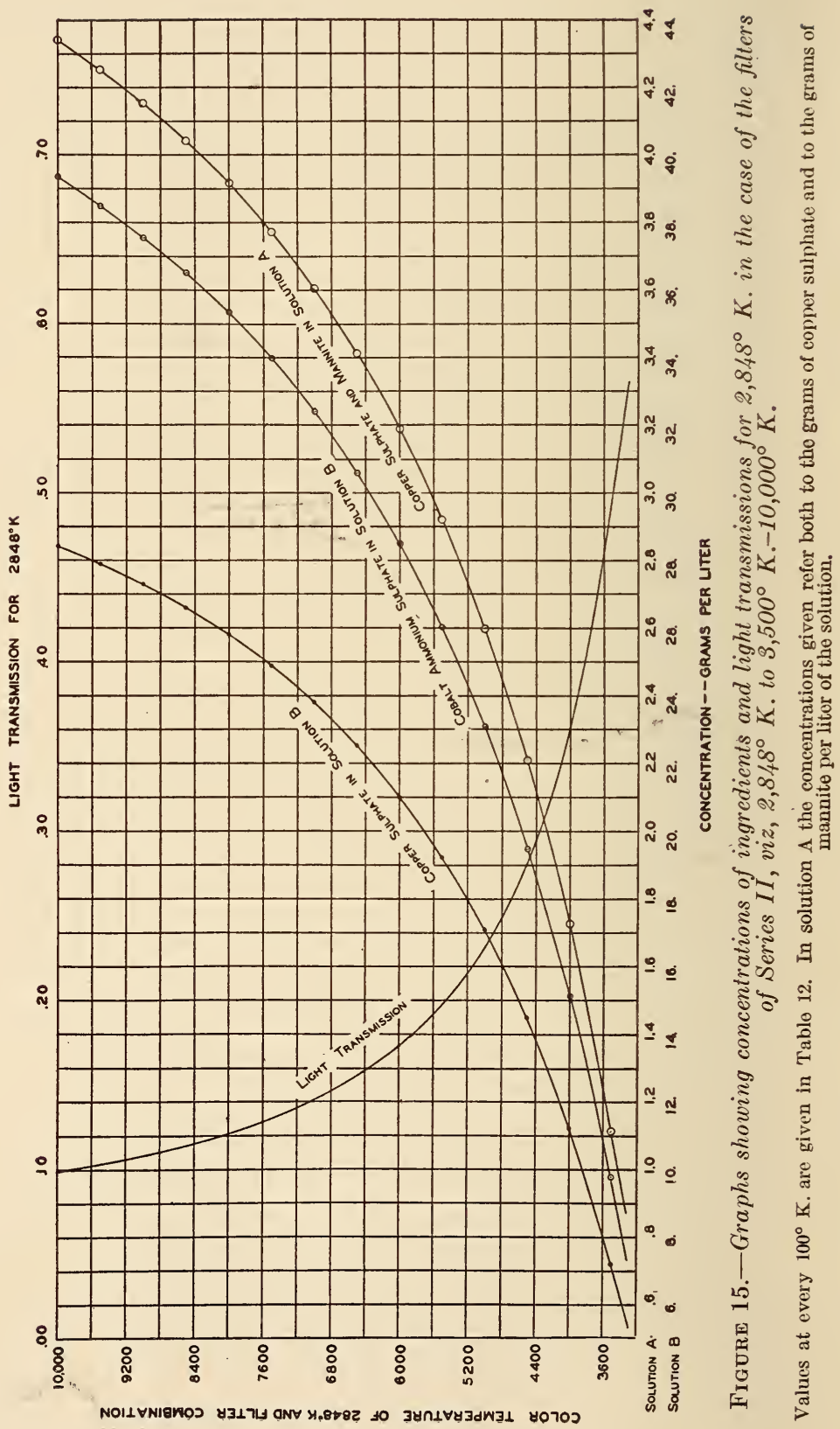


The color temperature of the Eastman Kodak Co.'s burner is generally taken to be $2,360^{\circ} \mathrm{K}$., although the energy distribution measured radiometrically by Coblentz gives a higher value as noted elsewhere. (Secs. III, 4 and VIII, 6.)

Figure 16 is a section of the $r-b$ diagram showing the locus ${ }^{15}$ of points representing colors of the black body from $2,000^{\circ}$ to $4,000^{\circ} \mathrm{K}$., together with the position of the acetylene burner computed from Coblentz's data $(r=0.51778, g=0.35719, b=0.12503)$. (A similar illustration for color temperatures from $4,000^{\circ}$ to $10,000^{\circ} \mathrm{K}$. is given in the preceding section.)

A filter was designed to convert the color-quality of the light from the acetylene lamp to that of mean sun, with the idea that it could

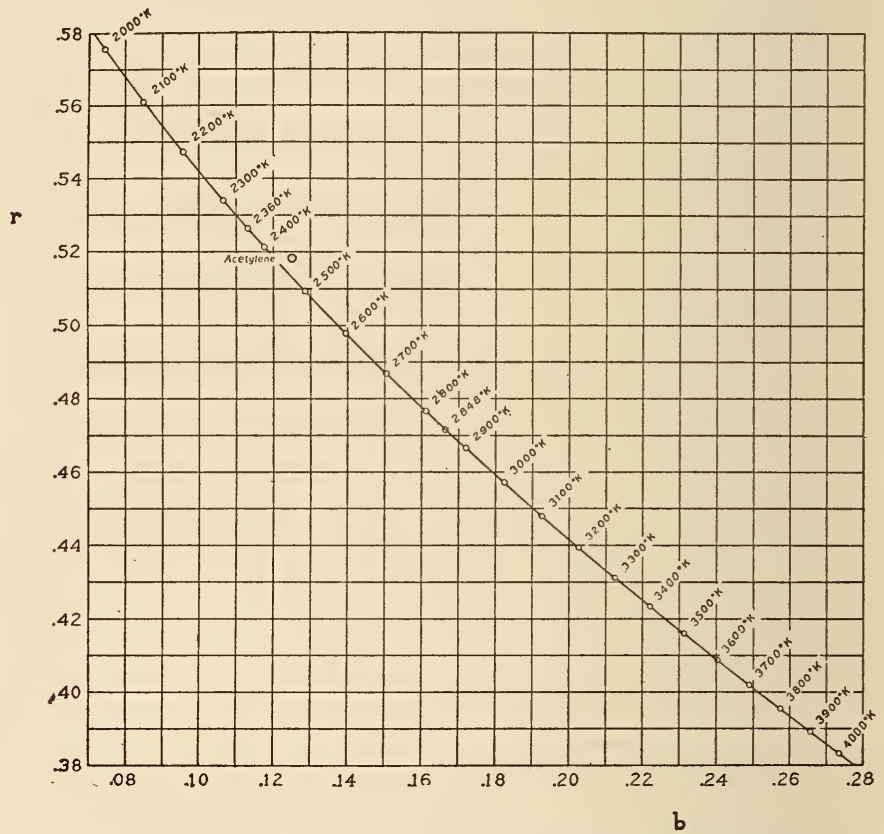

FIGURE 16.-Section of the r-b diagram showing the black-body locus and the position of the acetylene flame (as computed from Coblentz's energy data, Table 3)

(See fig. 14 for temperatures between $4,000^{\circ}$ and $10,000^{\circ} \mathrm{K}$.) Values of $r, g$, and $b$ are given for every $20^{\circ} \mathrm{K}$. in Table 11 . All values of $r, g$, and $b$ are computed on the basis of mean noon sunlight as the "neutral" stimulus.

be used for determining the color temperatures of incandescent lamps as outlined in Section VI, 2, $(d)$, as well as for photographic sensitometry. The spectral energy distribution used in the computation of this filter was that of Coblentz as given in Table 3, reduced to 100.00 at $560 \mathrm{~m} \mu$. The acetylene-to-mean-sun filter, by computation, gives a better energy match with the ideal than does that of the $2,360^{\circ}$ K.-to-mean-sun filter, as may be seen by comparing charts 36 and 2 .

The use of this filter in color temperature determinations is accompanied, however, by some uncertainty, because of the imperfect color

15 The expression "colorimetric locus" will hereafter be used to designate the locus of points representing colors on the trilinear diagram. Likewise, individual points on the diagram will be referred to as "colorimetric positions." 
match which may result when the acetylene flame and this filter is compared with, for example, a $2,360^{\circ} \mathrm{K}$. source and its filter, and because of the uncertainty of the color temperature of the acetylene flame. This is further discussed in Section. VIII, 6, where some tests with the filter are described. The use of the filter with the acetylene flame in photographic sensitometry should be entirely satisfactory.

(b) $2,848^{\circ} \mathrm{K}$. TO NOON SUNLIGHT AT SUMMER AND WINTER SOLSTICES

By methods exactly analogous to those used in designing the filters of Series I and already described in detail, filters were designed for converting $2,848^{\circ} \mathrm{K}$. to noon sunlight at Washington on June 21 and December 21, respectively, using Abbot's data as given in Table 1. As is the case with all the filters, an accurate color match was obtained between the ideal energy distribution and the source-andfilter combination. The filters are described in charts 34 and 35 . The trilinear coordinates for these sunlight distributions are illustrated in Figure 14. They are as follows: June 21, $r=0.32184, g=0.32688$, $b=0.35128$; December 21, $r=0.34569, g=0.34027, b=0.31404$.

\section{(c) $2,848^{\circ} \mathrm{K}$. TO ABBOT-PRIEST SUNLIGHT}

A description of the energy distribution known as Abbot-Priest sun, obtained with a $2,848^{\circ} \mathrm{K}$. source and quartz-nicol rotatorydispersion filter, js given in Section II and Figure 3. This representation of sunlight is quite satisfactory for colorimetric purposes and has been used in considerable work, both computation and direct observation, in the colorimetry section of the bureau. Because of the low light transmission of the rotatory-dispersion filter and relatively small field sizes available with it, and because the liquid filters may be used conveniently in many situations where the use of the rotatorydispersion filter is not feasible, it was suggested that it would be desirable to duplicate the color of Abbot-Priest sunlight by means of a Davis-Gibson filter with its relatively high light transmission.

The filter so designed is described and illustrated in chart 33 . Its light transmission for $2,848^{\circ} \mathrm{K}$. is 0.251 . A comparison of this filter and its resulting energy distribution with those for $2,848^{\circ} \mathrm{K}$. to mean sun and $2,848^{\circ}$ to $5,000^{\circ} \mathrm{K}$. (charts 8 and 24) illustrates the effect of the type of energy distribution which it is sought to duplicate upon the concentrations of the ingredients, the energy distribution of the source-and-filter combination, and the light transmission of the filter.

Methods of computation leading to the best proportions of ingredients to give a precise color match and a reasonably good energy match were similar to those used for the filters of Series I and II, with the exception that, in the color computation, the form containing excitations for Abbot-Priest sunlight was used. The trilinear coordinates of this energy distribution (on the basis of mean sun as "neutral" stimulus) are illustrated in Figure 14. They are as follows: $r=0.33472$, $g=0.33052, b=0.33476$.

Another filter for securing the color of Abbot-Priest sunlight is also available. This is the one described in the next section and illustrated in chart 32 and Figure 17. The locus obtained with this filter by varying the color temperature of the light source passes through Abbot-Priest sunlight at $2,567^{\circ} \mathrm{K}$. For this color temperature of source, the light transmission is 0.175 . 

(d) $2,848^{\circ} \mathrm{K}$. TO SUNLIGHT OUTSIDE EARTH'S ATMOSPHERE-VARIATION WITH
COLOR TEMPERATURE OF SOURCE

As representative of daylight energy conditions-sun plus sky, or overcast sky - the energy distribution of sunlight outside the earth's atmosphere is in our opinion more nearly correct than is that of any black body between the temperatures of $6,000^{\circ}$ and $7,000^{\circ} \mathrm{K}$., although it might, perhaps, be expected that such true absorption as there may be by the water vapor of the atmosphere would tend to make the color of daylight slightly less red than that of the outside sun. While the color of daylight may, perhaps, be represented to a close approximation on the color temperature scale, its energy distribution when thus specified undoubtedly suffers in accuracy just as sunlight does when represented by $5,000^{\circ} \mathrm{K}$.

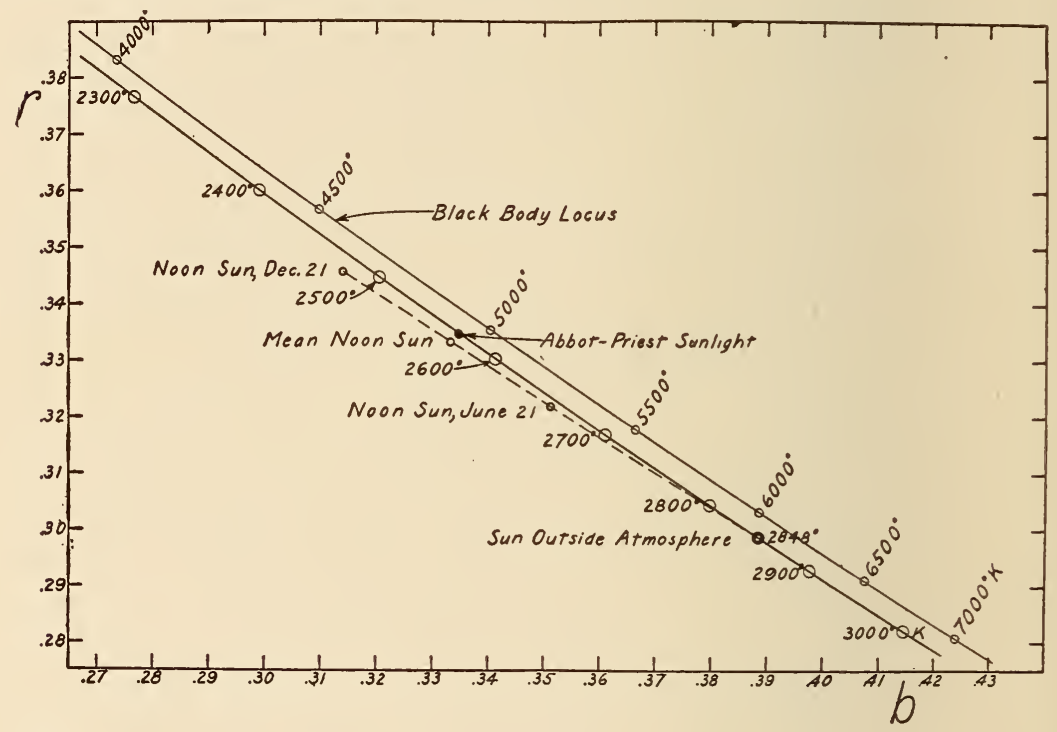

FIGURE 17.-Colorimetric locus obtained by varying the color temperature of source, as indicated, with the filter for converting $2,848^{\circ} \mathrm{K}$. to sunlight outside the earth's atmosphere

This locus passes practically through the point representing the color of Abbot-Priest sunlight when the light source is at $2,567^{\circ} \mathrm{K}$. The colors of daylight and noon sunlight may be closely matched with this filter and the variable source, as illustrated in Section VIII, 4 and Figure 32. The trilinear coordinates ("neutral" stimulus, mean sun), light transmissions, and color temperatures for this filter at every $20^{\circ} \mathrm{K}$. of source are given in Table 13.

With a view to its possible use as a reproducible standard of artificial daylight, a filter was designed for converting, $2,848^{\circ} \mathrm{K}$. to sunlight outside the earth's atmosphere, as represented by Abbot's data (Table 1) of 1917. The methods used were similar to those described above for the filters of Series II. A description of this filter is given in chart 32 . Its light transmission for $2,848^{\circ} \mathrm{K}$. is 0.180 .

The trilinear coordinates for this energy distribution are: $r=$ $0.29883, g=0.31261, b=0.38856$. Its location on the $r-b$ diagram is illustrated in Figure 14.

Such tests as have been made with this and other filters (Sec. VIII, 4) indicate that a close color match may be obtained by means of this filter not only with daylight, but also with noon sunlight at any time 
of the year, merely by varying the color temperature of the source. Accordingly, values of $r, g$, and $b$ were computed for this filter with the source at every $100^{\circ}$ of color temperature from $2,300^{\circ}$ to $3,000^{\circ}$ $\mathrm{K}$. These computed values are given in Table 13. Intermediate values at every $20^{\circ} \mathrm{K}$. were obtained by interpolation from a large scale plot. The locus of colors thus obtained with this filter by varying the color temperature of the source is shown in Figure 17.

The light transmissions of this filter for a black-body source varying over the range from $2,300^{\circ}$ to $3,000^{\circ} \mathrm{K}$. are also given in Table 13. They were computed at every $100^{\circ} \mathrm{K}$. and values obtained at intermediate temperatures by reading from a large scale graph. These computations were similar to those described in Section $\mathrm{V}, 4,(c)$. Methods of using this filter for the study of daylight and noon sunlight are outlined in Section VI, 2, (b).

TABLE 13.-Data resulting from varying the color temperature of the source in the case of the filter designed to convert $2,848^{\circ} \mathrm{K}$. to sun outside atmosphere-trilinear coordinates, light transmissions of filter, and color temperatures, as a function of color temperature of source.

Colorimetric positions are illustrated in Figure 17. The filter is described in chart 32.

\begin{tabular}{|c|c|c|c|c|c|c|c|c|c|c|c|}
\hline \multirow{2}{*}{$\begin{array}{l}\text { Color } \\
\text { temper- } \\
\text { ature } \\
\left({ }^{\circ} \mathrm{K} .\right) \text { of } \\
\text { source }\end{array}$} & \multicolumn{3}{|c|}{ Trilinear coordinates 1} & \multirow{2}{*}{$\begin{array}{l}\text { Light } \\
\text { trans- } \\
\text { mission }\end{array}$} & \multirow{2}{*}{\begin{tabular}{|c} 
"Color \\
tem- \\
pera- \\
ture" \\
by \\
Davis's \\
meth- \\
od ${ }^{2}$
\end{tabular}} & \multirow{2}{*}{$\begin{array}{l}\text { Color } \\
\text { temper- } \\
\text { ature } \\
\left({ }^{\circ} \mathrm{K} .\right) \text { of } \\
\text { source }\end{array}$} & \multicolumn{3}{|c|}{ Trilinear coordinates 1} & \multirow{2}{*}{$\mid \begin{array}{c}\text { Light } \\
\text { trans- } \\
\text { mission }\end{array}$} & \multirow{2}{*}{$\begin{array}{l}\text { "Color } \\
\text { tem- } \\
\text { pera- } \\
\text { ture" } \\
\text { by } \\
\text { Davis's } \\
\text { meth- } \\
\text { od }{ }^{2}\end{array}$} \\
\hline & $r$ & $g$ & $b$ & & & & $r$ & $g$ & $b$ & & \\
\hline $\begin{array}{l}2,300 \ldots \\
2,320 \ldots \\
2,340 \ldots \\
2,360 \ldots \\
2,380 \ldots\end{array}$ & $\begin{array}{l}0.37655 \\
.3731 \\
.3698 \\
.3665 \\
.3632\end{array}$ & \begin{tabular}{|c}
0.34684 \\
.3457 \\
.3445 \\
.3433 \\
.3421
\end{tabular} & $\begin{array}{l}0.27660 \\
.2812 \\
.2857 \\
.2902 \\
.2947\end{array}$ & $\begin{array}{l}0.1700 \\
.1704 \\
.1708 \\
.1712 \\
.1716\end{array}$ & $\begin{array}{l}{ }^{\circ} K . \\
4,217 \\
4,285 \\
4,353 \\
4,423 \\
4,493\end{array}$ & $\begin{array}{l}2,700 \ldots \\
2,720 \ldots \\
2,740 \ldots \\
2,760 \ldots \\
2,780_{\ldots} \ldots\end{array}$ & $\begin{array}{c}0.31689 \\
.3143 \\
.3118 \\
.3093 \\
.3069\end{array}$ & $\begin{array}{c}0.32199 \\
.3207 \\
.3194 \\
.3182 \\
.3169\end{array}$ & $\begin{array}{c}0.36112 \\
.3650 \\
.3678 \\
.3726 \\
.3762\end{array}$ & $\begin{array}{l}0.1776 \\
.1779 \\
.1783 \\
.1786 \\
.1789\end{array}$ & $\begin{array}{l}{ }^{\circ} K . \\
5,812 \\
5,905 \\
6,001 \\
6,099 \\
6,199\end{array}$ \\
\hline $\begin{array}{l}2,400 \ldots \\
2,420 \ldots \\
2,440 \\
2,460 \\
2,480\end{array}$ & $\begin{array}{l}.36006 \\
.3569 \\
.3538 \\
.3507 \\
.3477\end{array}$ & $\begin{array}{l}.34088 \\
.3397 \\
.3384 \\
.3372 \\
.3359\end{array}$ & $\begin{array}{l}.29907 \\
.3034 \\
.3078 \\
.3120 \\
.3163\end{array}$ & $\begin{array}{l}.1721 \\
.1725 \\
.1729 \\
.1733 \\
.1736\end{array}$ & $\begin{array}{l}4,561 \\
4,638 \\
4,713 \\
4,789 \\
4,867\end{array}$ & $\begin{array}{l}2,800 \ldots \\
2,820 \ldots \\
2,840 \ldots \\
2,860 \\
2,880\end{array}$ & $\begin{array}{l}.30452 \\
.3021 \\
.2998 \\
.2974 \\
.2951\end{array}$ & $\begin{array}{l}.31565 \\
.3144 \\
.3131 \\
.3119 \\
.3106\end{array}$ & & $\begin{array}{l}.1792 \\
.1795 \\
.1799 \\
.1802 \\
.1805\end{array}$ & $\begin{array}{l}6,304 \\
6,409 \\
6,517 \\
6,631 \\
6,746\end{array}$ \\
\hline $\begin{array}{l}2,500 \ldots \\
2,520 \ldots \\
2,540 \ldots \\
2,560 \ldots \\
2,580 \ldots\end{array}$ & $\begin{array}{l}.34470 \\
.3417 \\
.3387 \\
.3358 \\
.3320\end{array}$ & $\begin{array}{l}.33471 \\
.3334 \\
.3322 \\
.3309 \\
.3296\end{array}$ & $\begin{array}{l}.32059 \\
.3248 \\
.3290 \\
.3332 \\
.3374\end{array}$ & $\begin{array}{l}.1740 \\
.1744 \\
.1748 \\
.1751 \\
.1755\end{array}$ & $\begin{array}{l}4,945 \\
5,025 \\
5,106 \\
5,188 \\
5,271\end{array}$ & $\begin{array}{l}2,900 \ldots \\
2,920 \ldots \\
2,940 \\
2,950 \\
2,980\end{array}$ & $\begin{array}{l}.29290 \\
.2907 \\
.2885 \\
.2863 \\
.2842\end{array}$ & $\begin{array}{l}.30937 \\
.3081 \\
.3069 \\
.3057 \\
.3045\end{array}$ & $\begin{array}{l}.39773 \\
.4012 \\
.4046 \\
.4079 \\
.4113\end{array}$ & $\begin{array}{l}.1808 \\
.1811 \\
.1814 \\
.1817 \\
.1820\end{array}$ & $\begin{array}{l}6,864 \\
6,987 \\
7,112 \\
7,240 \\
7,369\end{array}$ \\
\hline $\begin{array}{l}2,600 \ldots \\
2,620 \ldots \\
2,640 \ldots \\
2,660 \\
2,680 \ldots\end{array}$ & $\begin{array}{l}.33029 \\
.3275 \\
.3248 \\
.3221 \\
.3195\end{array}$ & $\begin{array}{l}.32835 \\
.3271 \\
.3258 \\
.3245 \\
.3232\end{array}$ & $\begin{array}{l}.34136 \\
.3454 \\
.3494 \\
.3533 \\
.3573\end{array}$ & $\begin{array}{l}.1759 \\
.1762 \\
.1766 \\
.1769 \\
.1773\end{array}$ & $\begin{array}{l}5,357 \\
5,445 \\
5,535 \\
5,626 \\
5,718\end{array}$ & 2,848 & .28218 & $\begin{array}{r}.30327 \\
.31261\end{array}$ & $\begin{array}{r}.41455 \\
.38855\end{array}$ & $3^{1823} \cdot 1800$ & 7,497 \\
\hline
\end{tabular}

1 "Neutral" stimulus: Mean sun as adopted in this investigation. Excitations: Optical Society of America extrapolated (J. Opt. Soc. Am. and Rev. Sci. Inst., 10, p. 230; 1925). Computed values are given to five significant figures; other values, to four significant figures, were read from large-scale graph plotted from computed values.

2 There is as yet no satisfactory, established method for computing the "color temperature"-that is, the nearest black-body color-for colors not lying precisely on the black-body locus. The values of color temperature given in Tables 13,14 , and 15 were obtained by an empiric method of computation developed by Davis. This method is, briefly, as follows: Values of $r L_{\mathrm{r}}, g L_{\mathrm{g}}$, and $b L_{\mathrm{b}}$ are computed for the energy distribution in question, where $r, g$, and $b$ are the trilinear coordinates and $L_{\mathrm{r}}, L_{\mathrm{g}}$, and $L_{\mathrm{b}}$ are the luminosity coefficients ( $=0.45014,0.54417$, and 0.00569 , respectively, as derived by Davis from least-squares adjustment of the O.S. A. excitations (extrapolated) to the visibility data of Table 10). These values are then multiplied by a factor, $\omega$, of such magnitude that $\omega r L_{\mathrm{r}}+\omega g L_{\mathrm{g}}+\omega b L_{\mathrm{b}}=0.33333$. These values are then compared, respectively, with similar values for the black-body energy distributions, which have been computed at closely adjacent intervals over the range from $1,600^{\circ}$ to $20,000^{\circ} \mathrm{K}$. Three "component temperatures" will thus be obtained and their arithmetical mean is taken as the color temperature. For the sake of relative values and maintaining regularity of differences in the tabulated values, these color temperatures have been computed with a greater precision than their accuracy can be guaranteed. It is impossible at this time to indicate definitely the accuracy of the values. The justification for the method is: (1) That it seems to give reasonable values, (2) that it is computationally precise, and (3) that no other wholly satisfactory method is available. The method just outlined has other features than here noted. These are reserved for discussion in a separate paper, along with a more detailed description and illustration of the above procedure, including the table of values of $\omega r L_{\mathrm{r}}, \omega g L_{\mathrm{g}}, \omega b L_{\mathrm{b}}$, summing to 0.33333 , for the black-body series. 
(e) $2,450^{\circ}$ TO $3,500^{\circ} \mathrm{K}$. AND TO $6,500^{\circ} \mathrm{K}$.-VARIATION WITH COLOR TEMPERATURE OF SOURCE

The filters of Series II, with the source at $2,848^{\circ} \mathrm{K}$. provide a means for reproducing any desired black-body color from $3,500^{\circ}$ to $10,000^{\circ}$ $\mathrm{K}$. with high precision. It would be possible with any of these filters, by varying the color temperature of the source, to obtain a locus of colors slightly inclined to the black-body locus, and crossing it at the color temperature for which the filter was designed. Such a filter would thus enable various high color temperatures to be approximately obtained by merely varying the color temperature of the source.

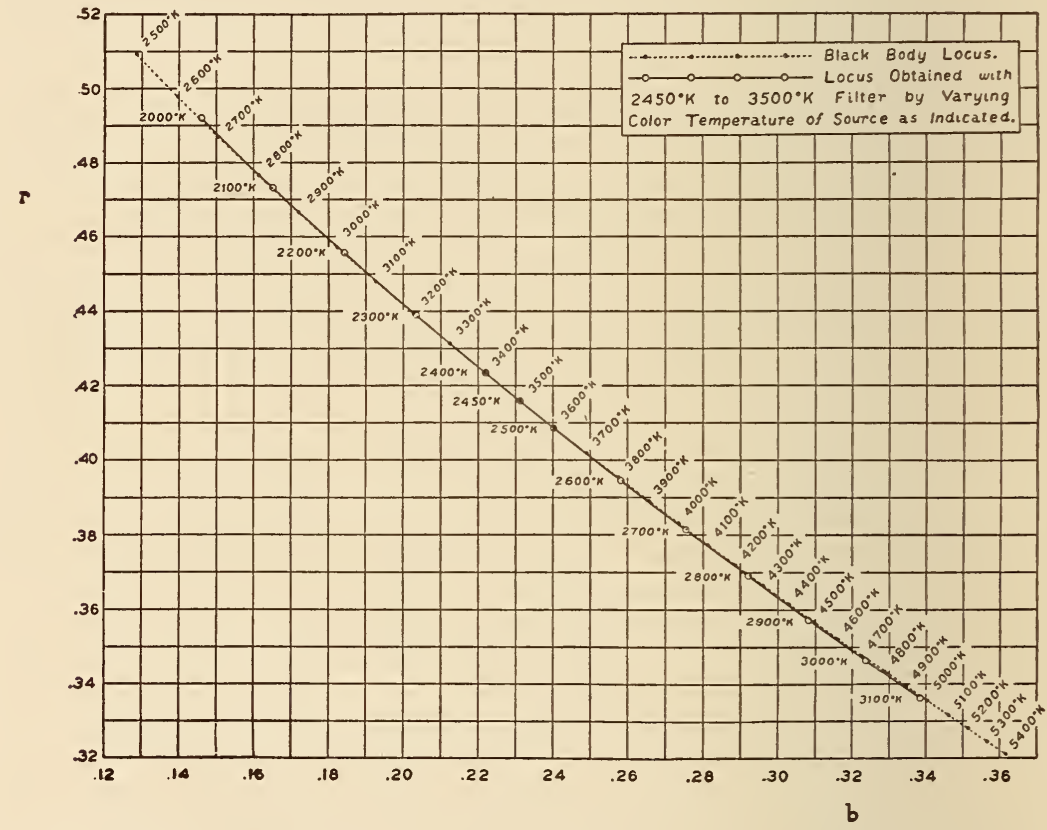

FIGURE 18.-Colorimetric locus obtained by varying the color temperature of source, as indicated, with the filter for converting $2,450^{\circ}$ to $3,500^{\circ} \mathrm{K}$., compared to the black-body locus

The trilinear coordinates ("neutral" stimulus, mean sun), light transmissions, and color temperatures for this filter at every $20^{\circ} \mathrm{K}$. of source are given in Table 14 .

This color temperature of source $\left(2,848^{\circ} \mathrm{K}\right.$.) is eminently suitable for the filters of Series II and for the various miscellaneous filters where it is used. The higher the color temperature of source the better spectral energy match can be secured. However, the ordinary gas-filled lamps do not operate normally at much higher color temperatures than $2,848^{\circ} \mathrm{K}$. so that to raise this value would ordinarily shorten the life of the lamps to an undesirable degree. It is believed the value of $2,848^{\circ} \mathrm{K}$. is a very satisfactory compromise for the purpose.

When, however, it is desired to design a filter by which a range of color temperatures may be secured by varying the color temperature of the source, the point of exact color match with the black-body 
locus should be chosen near the middle of the desired range, not near its upper limit as would be the case with the $2,848^{\circ} \mathrm{K}$. filters, so that the deviations resulting from the crossing of the two loci may be kept as small as possible.

The practicable working range of a gas-filled lamp may be considered as from $2,000^{\circ}$ to $3,100^{\circ} \mathrm{K}$., although there are certain objections to operation near either extreme. The mid point of this range of colors is approximately at $2,450^{\circ} \mathrm{K}$., as estimated on the assumption that the sensation scale along the black-body locus of colors is proportional to the spectral centroid (30, p. 1191). It was desired to have one filter by which the complete range of color temperatures conceivably called white could be covered. It was found that by means of a filter converting $2,450^{\circ}$ to $6,500^{\circ} \mathrm{K}$., a range of colors closely approxi-

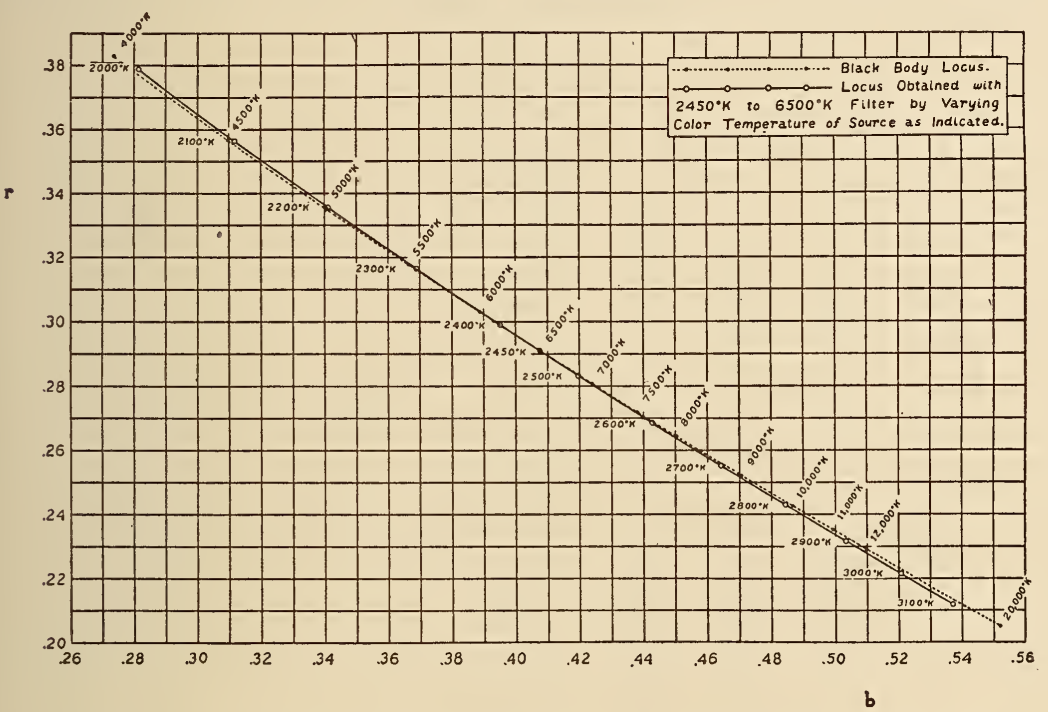

FIGURE 19.-Colorimetric locus obtained by varying the color temperature of source, as indicated, with the filter for converting $2,450^{\circ}$ to $6,500^{\circ} \mathrm{K}$., compared to the black-body locus

The trilinear coordinates ("neutral" stimulus, mean sun), light transmissions, and color temperatures for this filter at every $20^{\circ} \mathrm{K}$. of source are given in Table 15 .

mating those of a black body from about $4,000^{\circ}$ to $19,000^{\circ} \mathrm{K}$. could be obtained by varying the source from $2,000^{\circ}$ to $3,100^{\circ} \mathrm{K}$.

A filter was accordingly designed converting $2,450^{\circ}$ to $6,500^{\circ} \mathrm{K}$. with an accurate color match. Methods of design were similar to those previously described. A second filter was also designed, converting $2,450^{\circ}$ to $3,500^{\circ} \mathrm{K}$. so that by means of these two filters and the source alone a range of colors closely approximating blackbody colors from $2,000^{\circ} \mathrm{K}$. or below to about $19,000^{\circ} \mathrm{K}$. could be obtained.

These filters are described and illustrated in charts 37 and 38 . In Tables 14 and 15 are given the values of $r, g$, and $b$, the light transmissions, and the color temperatures (via Davis's method) attainable when the color temperature of the source is varied. Comparisons with the black-body locus are shown in Figures 18 and 19. 
Deviations of the colors so obtained from the nearest black-body colors are in all cases considered to be less than one satron (Sec. VIII, 2 ), so that these filters may be considered as affording a means of practically duplicating all the black-body colors from $2,000^{\circ} \mathrm{K}$. or below up to about $19,000^{\circ} \mathrm{K}$.

TABLE 14.-Data resulting from varying the color temperature of the source in the case of the filter designed to convert $2,450^{\circ}$ to $3,500^{\circ} \mathrm{K}$.-trilinear coordinates, light transmissions of filter, and color temperatures, as a function of color temperature of source

Colorimetric positions are illustrated in Figure 18. The filter is described in chart 37

\begin{tabular}{|c|c|c|c|c|c|c|c|c|c|c|c|}
\hline \multirow{2}{*}{$\begin{array}{c}\text { Color } \\
\text { tempera- } \\
\text { ture } \\
\left({ }^{\circ} \mathrm{K} .\right) \text { of } \\
\text { source }\end{array}$} & \multicolumn{3}{|c|}{ Trilinear coordinates 1} & \multirow{2}{*}{$\begin{array}{l}\text { Light } \\
\text { trans- } \\
\text { mission }\end{array}$} & \multirow{2}{*}{$\begin{array}{c}\text { "Color } \\
\text { tempera- } \\
\text { ture" } \\
\text { by } \\
\text { Davis's } \\
\text { method } 2\end{array}$} & \multirow{2}{*}{$\begin{array}{l}\text { Color } \\
\text { tempera- } \\
\text { ture }\left({ }^{\circ} \mathrm{K} .\right) \\
\text { of source }\end{array}$} & \multicolumn{3}{|c|}{ Trilinear coordinates 1} & \multirow{2}{*}{$\begin{array}{l}\text { Light } \\
\text { trans- } \\
\text { mission }\end{array}$} & \multirow{2}{*}{$\begin{array}{l}\text { "Color } \\
\text { temper- } \\
\text { ture" } \\
\text { by } \\
\text { Davis's } \\
\text { method }\end{array}$} \\
\hline & $r$ & $g$ & $b$ & & & & $r$ & $g$ & $b$ & & \\
\hline $\begin{array}{l}2,000 \\
2,020 \ldots \\
2,040 \ldots \\
2,060 \\
2,080_{\ldots}\end{array}$ & $\begin{array}{l}0.49206 \\
.4883 \\
.4845 \\
.4807 \\
.4770\end{array}$ & $\begin{array}{l}0.36195 \\
.3619 \\
.3619 \\
.3618 \\
.3617\end{array}$ & $\begin{array}{l}0.14599 \\
.1498 \\
.1536 \\
.1575 \\
.1614\end{array}$ & $\begin{array}{l}0.2850 \\
.2855 \\
.2861 \\
.2866 \\
.2871\end{array}$ & $\begin{array}{l}{ }^{\circ} K . \\
2,649 \\
2,685 \\
2,721 \\
2,757 \\
2,793\end{array}$ & $\begin{array}{l}2,600 \ldots \\
2,620 \ldots \\
2,640 \ldots \\
2,660 \ldots \\
2,680_{\ldots}\end{array}$ & $\begin{array}{l}0.39459 \\
.3919 \\
.3892 \\
.3865 \\
.3839\end{array}$ & $\begin{array}{l}0.34733 \\
.3465 \\
.3457 \\
.3449 \\
.3441\end{array}$ & $\begin{array}{l}0.25808 \\
.2616 \\
.2651 \\
.2686 \\
.2720\end{array}$ & $\begin{array}{r}0.2982 \\
.2986 \\
.2989 \\
.2993 \\
.2996\end{array}$ & $\begin{array}{l}{ }^{\circ} \bar{K} . \\
3,816 \\
3,859 \\
3,903 \\
3,947 \\
3,992\end{array}$ \\
\hline $\begin{array}{l}2,100 \ldots \\
2,120 \ldots \\
2,140 \ldots \\
2,160 \ldots \\
2,180_{-}\end{array}$ & $\begin{array}{l}.47334 \\
.4697 \\
.4662 \\
.4626 \\
.4592\end{array}$ & $\begin{array}{l}.36148 \\
.3612 \\
.3609 \\
.3606 \\
.3603\end{array}$ & $\begin{array}{l}.16519 \\
.1690 \\
.1729 \\
.1767 \\
.1805\end{array}$ & $\begin{array}{l}.2876 \\
.2881 \\
.2886 \\
.2891 \\
.2895\end{array}$ & $\begin{array}{l}2,829 \\
2,865 \\
2,901 \\
2,939 \\
2,976\end{array}$ & $\begin{array}{l}2,700 \ldots \\
2,720 \ldots \\
2,740 \ldots \\
2,760 \ldots \\
2,780 \ldots\end{array}$ & $\begin{array}{l}.38138 \\
.3790 \\
.3764 \\
.3739 \\
.3715\end{array}$ & $\begin{array}{l}.34325 \\
.3424 \\
.3416 \\
.3407 \\
.3398\end{array}$ & & $\begin{array}{l}.3000 \\
.3003 \\
.3007 \\
.3010 \\
.3013\end{array}$ & $\begin{array}{l}4,038 \\
4,082 \\
4,126 \\
4,171 \\
4,216\end{array}$ \\
\hline $\begin{array}{l}2,200 \ldots \\
2,220 \ldots \\
2,240 \ldots \\
2,260 \ldots \\
2,280 \ldots\end{array}$ & $\begin{array}{l}.45576 \\
.4523 \\
.4489 \\
.4456 \\
.4423\end{array}$ & $\begin{array}{l}.35991 \\
.3595 \\
.3590 \\
.3586 \\
.3581\end{array}$ & $\begin{array}{l}.18433 \\
.1882 \\
.1920 \\
.1958 \\
.1996\end{array}$ & $\begin{array}{l}.2900 \\
.2905 \\
.2909 \\
.2914 \\
.2919\end{array}$ & $\begin{array}{l}3,012 \\
3,051 \\
3,083 \\
3,127 \\
3,165\end{array}$ & $\begin{array}{l}2,800 \ldots \\
2,820 \ldots \\
2,840 \ldots \\
2,860 \ldots \\
2,880 \ldots\end{array}$ & $\begin{array}{l}.36907 \\
.3666 \\
.3643 \\
.3619 \\
.3596\end{array}$ & $\begin{array}{l}.33895 \\
.3381 \\
.3372 \\
.3363 \\
.3354\end{array}$ & & $\begin{array}{l}.3016 \\
.3019 \\
.3023 \\
.3026 \\
.3029\end{array}$ & $\begin{array}{l}4,262 \\
4,309 \\
4,356 \\
4,404 \\
4,453\end{array}$ \\
\hline $\begin{array}{l}2,300 \ldots \\
2,320 \ldots \\
2,340 \ldots \\
2,360 \ldots \\
2,380 \ldots\end{array}$ & $\begin{array}{l}.43904 \\
.4358 \\
.4327 \\
.4295 \\
.4264\end{array}$ & $\begin{array}{l}.35757 \\
.3570 \\
.3564 \\
3558 \\
.3552\end{array}$ & $\begin{array}{l}.20339 \\
.2071 \\
.2109 \\
.2146 \\
.2183\end{array}$ & $\begin{array}{l}.2923 \\
.2927 \\
.2932 \\
.2936 \\
.2940\end{array}$ & $\begin{array}{l}3,202 \\
3,242 \\
3,281 \\
3,320 \\
3,359\end{array}$ & $\begin{array}{l}2,900 \ldots \\
2,920 \ldots \\
2,940 \ldots \\
2,960 \ldots \\
2,980 \ldots\end{array}$ & $\begin{array}{l}.35735 \\
.3551 \\
.3529 \\
.3507 \\
.3485\end{array}$ & $\begin{array}{l}.33451 \\
.3336 \\
.3327 \\
.3318 \\
.3309\end{array}$ & & $\begin{array}{l}.3032 \\
.3035 \\
.3038 \\
.3041 \\
.3044\end{array}$ & $\begin{array}{l}4,502 \\
4,551 \\
4,600 \\
4,650 \\
4,700\end{array}$ \\
\hline $\begin{array}{l}2,400 \ldots \\
2,420 \ldots \\
2,440 \\
2,460 \\
2,480\end{array}$ & $\begin{array}{l}.42337 \\
.4204 \\
.4174 \\
.4144 \\
.4115\end{array}$ & $\begin{array}{l}.35460 \\
.3539 \\
.3533 \\
.3526 \\
.3519\end{array}$ & $\begin{array}{l}.22203 \\
.2257 \\
.2294 \\
.2330 \\
.2366\end{array}$ & $\begin{array}{l}.2944 \\
.2948 \\
.2952 \\
.2955 \\
.2959\end{array}$ & $\begin{array}{l}3,398 \\
3,439 \\
3,480 \\
3,521 \\
3,563\end{array}$ & $\begin{array}{l}3,000 \ldots \\
3,020 \ldots \\
3,040 \ldots \\
3,060 \\
3,080\end{array}$ & $\begin{array}{l}.34642 \\
.3443 \\
.3422 \\
.3402 \\
.3381\end{array}$ & $\begin{array}{l}.33005 \\
.3291 \\
.3282 \\
.3273 \\
.3264\end{array}$ & $\begin{array}{l}.32352 \\
.3265 \\
.3295 \\
.3325 \\
.3355\end{array}$ & $\begin{array}{l}.3047 \\
.3050 \\
.3053 \\
.3056 \\
.3058\end{array}$ & $\begin{array}{l}4,751 \\
4,803 \\
4,855 \\
4,908 \\
4,961\end{array}$ \\
\hline $\begin{array}{l}2,500 \ldots \\
2,520 \ldots \\
2,540 \ldots \\
2,560 \ldots \\
2,580_{\ldots}\end{array}$ & $\begin{array}{l}.40861 \\
.4057 \\
.4029 \\
.4001 \\
.3973\end{array}$ & $\begin{array}{l}.35117 \\
.3504 \\
.3497 \\
.3489 \\
.3481\end{array}$ & $\begin{array}{l}.24022 \\
.2438 \\
.2474 \\
.2510 \\
.2545\end{array}$ & $\begin{array}{l}.2963 \\
.2967 \\
.2971 \\
.2975 \\
.2978\end{array}$ & $\begin{array}{l}3,605 \\
3,647 \\
3,688 \\
3,730 \\
3,773\end{array}$ & $3,100 \ldots$ & .33607 & .32555 & .33839 & .3061 & 5,015 \\
\hline
\end{tabular}

1 "Neutral" stimulus: Mean sun as adopted in this investigation. Excitations: Optical Society of America extrapolated (J. Opt. Soc. Am. and Rev. Sci. Inst., 10, p. 230; 1925). Computed values are given to five significant figures; other values, to four significant figures, were read from large-scale graph plotted from computed values.

2 There is as yet no satisfactory, established method for computing the "color temperature"-that is, the nearest black-body color-for colors not lying precisely on the black-body locus. The values of color temperature given in Tables 13,14 , and 15 were obtained by an empiric method of computation developed by Davis. This method is, briefly, as follows: Values of $r L_{\mathrm{r}}, g L_{\mathrm{g}}$, and $b L_{\mathrm{b}}$ are computed for the energy distribution in question, where $r, g$, and $b$ are the trilinear coordinates and $L_{\mathrm{r}}, L_{\mathrm{g}}$, and $L_{\mathrm{b}}$ are the luminosity coefficients $(=0.45014,0.54417$, and 0.00569 , respectively, as derived by Davis from least-squares adjustment of the O.S. A.. excitations (extrapolated) to the visibility data of Table 10). These values are then multiplied by a factor, $\omega$, of such magnitude that $\omega r L_{\mathrm{r}}+\omega g L_{\mathrm{g}}+\omega b L_{\mathrm{b}}=0.33333$. These values are then compared, respectively, with similar values for the black-body energy distributions, which have been computed at closely adjacent intervals over the range from $1,600^{\circ}$ to $20,000^{\circ} \mathrm{K}$. Three "component temperatures" will thus be obtained and their arithmetical mean is taken as the color temperature. For the sake of relative values, and maintaining regularity of differences in the tabulated values, these color temperatures have been computed with a greater precision than their accuracy can be guaranteed. It is impossible at this time to indicate definitely the accuracy of the values. The justification for the method is: (1) That it seems to give reasonable values, (2) that it is computationally precise, and (3) that no other wholly satisfactory method is available. The method just outlined has other features than here noted. These are reserved for discussion in a separate paper, along with a more detailed description and illustration of the above procedure, including the table of values of $\omega r L_{r}, \omega g L_{\mathrm{g}}, \omega b L_{\mathrm{b}}$, summing to 0.33333 , for the black-body series. 
TABLE 15.-Data resulting from varying the color temperature of the source in the case of the filter designed to convert $2,450^{\circ}$ to $6,500^{\circ} \mathrm{K}$. - trilinear coordinates, light transmissions of filter, and color temperatures as a function of color temperature of source

Colorimetric positions are illustrated in Figure 19. The filter is described in chart 38

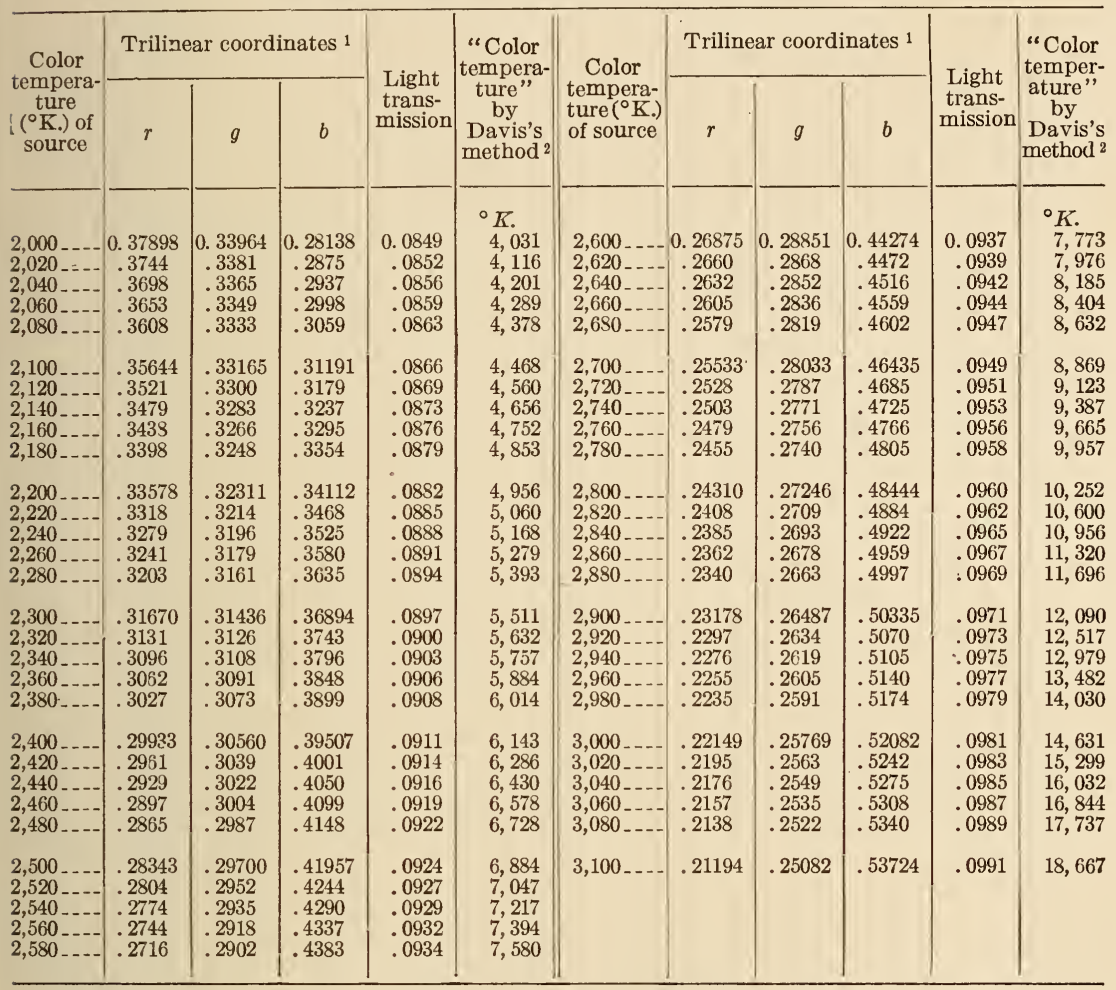

1 "Neutral" stimulus: Mean sun as adopted in this investigation. Excitations: Optical Society of America extrapolated (J. Opt. Soc. Am. and Rev. Sci. Inst., 10, p. 230; 1925). Computed values are given to five significant figures; other values, to four significant figures, were read from large scale graph plotted from computed values.

2 There is as yet no satisfactory, established method for computing the "color temperature"-that is, the nearest black-body color-for colors not lying precisely on the black-body locus. The values of color temperature given in Tables 13,14, and 15 were obtained by an empiric method of computation developed by Davis. This method is, briefly, as follows: Values of $r L_{r}, g L_{g}$, and $b L_{b}$ are computed for the energy distribution in question, where $r, g$, and $b$ are the trilinear coordinates and $L_{r}, L_{g}$, and $L_{b}$ are the luminosity coefficients $(=0.45014,0.54417$, and 0.00569 , respectively, as derived by Davis from least-squares adjustment of the O.S. A. excitations (extrapolated) to the visibility data of Table 10). These values are then multiplied by a factor, $\omega$, of such magnitude that $\omega r L_{r}+\omega g L_{g}+\omega b L_{b}=0.33333$. These values are then compared, respectively, with similar values for the black-body energy distributions, which have been computed at closely adjacent intervals over the range from $1,600^{\circ}$ to $20,000^{\circ} \mathrm{K}$. Three "component temperatures" will thus be obtained and their arithmetical mean is taken as the color temperature. For the sake of relative values and maintaining regularity of differences in the tabulated values, these color temperatures have been computed with a greater precision than their accuracy can be guaranteed. It is impossible at this time to indicate definitely the accuracy of the values. The justification for the method is: (1) That it seems to give reasonable values, (2) that it is computationally precise, and (3) that no other wholly satisfactory method is available. The method just outlined has other features than here noted. These are reserved for discussion in a separate paper, along with a more detailed description and illustration of the above procedure, including the table of values of $\omega r L_{r}, \omega g L_{g}, \omega b L_{b}$, summing to 0.33333 , for the black-body series.

\section{USE OF THE FILTERS}

Certain of the uses to which these filters may be put have already been noted in connection with the discussions of the reasons for designing the various filters. Such uses are more specifically outlined in the present section and, in addition, other classes of work for 
which the filters are readily adaptable are given. The use of the standard component solutions (Tables 4, 5, and 6), in checking or calibrating spectrophotometric apparatus is discussed later in Section VII, 10

\section{IN PHOTOGRAPHIC SENSITOMETRY}

(a) INTERNATIONAL UNIT OF INTENSITY FOR SENSITOMETRY

The need for an accurately reproducible filter for obtaining a spectral distribution of energy suitable for photographic sensitometry was, as already stated, one of the principal objectives of the present investigation. Likewise, in the fields of colorimetry and photometry, filters have been needed for converting low color temperatures to high color temperatures and for calibrating incandescent lamps for color temperature and intensity. In designing filters for use in these fields, a relatively large number have been developed giving colors and energy distributions approximating those of sunlight and daylight, and, therefore, suitable for use in photographic sensitometry.

The action of the Sixth International Congress of Photography in 1925 and the report of the American Committee on the Photographic Standard of Intensity were noted in the introduction. The subject was considered again at the Seventh International Congress of Photography meeting in London in July, 1928. At that time the American committee made another report (40) to the congress repeating its recommendation for a single high color temperature standard of light quality for use in sensitometry (as contrasted to the dual standard adopted in 1925), and urging the use of the DavisGibson filters, particularly the $2,360^{\circ} \mathrm{K}$.-to-mean-sun filter, as a means of securing the desired sunlight distribution in the laboratory. A paper by the authors, entitled, "Artificial Sunlight for Photographic Sensitometry," was also read at the congress. (Proceedings, pp. 611170.)

The action of the Seventh International Congress has been described elsewhere (41). It is sufficient here to quote the resolution adopted, this quotation being taken from the published Proceedings, page 173?

This meeting of the Seventh International Congress recommends to the national committees that the photographic unit of intensity for the sensitometry of negative materials shall be defined as the intensity of a filtered source of radiation having a luminous intensity of 1 international candle, and produced by a gray body at a colour temperature of $2,360^{\circ} \mathrm{K}$., together with a selectively absorbing filter made up as follows: Two solutions compounded according to the following formula, the complete filter to consist of $1 \mathrm{~cm} *$ layer of each solution contained in a double cell made by using three pieces of borosilicate crown glass (refractive index, $D=1.51$ ), each $2.5 \mathrm{~mm}$ thick.

\section{Solution $A$}

Copper sulphate $\left(\mathrm{CuSO}_{4} .5 \mathrm{H}_{2} \mathrm{O}\right)_{\ldots} \ldots \ldots$

Mannite $\left(\mathrm{C}_{6} \mathrm{H}_{8}(\mathrm{OH})_{6}\right)$

Pyridine $\left(\mathrm{C}_{5} \mathrm{H}_{5} \mathrm{~N}\right)$

Water (distilled) to make..... 1, 000

\section{Solution $B$}

Cobalt ammonium sulphate $\left(\mathrm{CoSO}_{4} \cdot\left(\mathrm{NH}_{4}\right)_{2} \mathrm{SO}_{4} \cdot 6 \mathrm{H}_{2} \mathrm{O}\right)_{-}-\mathrm{g}-\mathrm{-}_{-} \uparrow 26.827$

Copper sulphate $\left(\mathrm{CuSO}_{4} .5 \mathrm{H}_{2} \mathrm{O}\right)$

Sulphuric acid (specific gravity 1.835)

Water (distilled) to make......... 1,000

\footnotetext{
* Tolerance in thickness shall be $\pm 0.05 \mathrm{~mm}$.

$\dagger$ For practical purposes an accuracy to the second place of decimals is probably sufficient.

** Editors' Note.-It is obvious that this $30 \mathrm{cc}$ refers to pure pyridine, and that the appropriate volume correction should be applied if pyridine of lesser purity is used.
} 
It is recommended that the foregoing resolution shall come into force as a decision of this Seventh International Congress if and when ratified by the national committees represented at this congress.

('The editors' note given just above, as published in the Proceedings, p. 173, was not a part of the resolution adopted and is in error, since the pyridine used in designing the filters was of 98.4 per cent strength, as explained on p. 165 of the authors' paper published in the Proceedings.)

The filter herein specified is the Davis-Gibson filter described in chart 2 of the present paper. In accordance with the last sentence of the resolution, the matter was considered ${ }^{16}$ by the Optical Society of America, through its council, meeting in February, 1929, and the recommendation of the Seventh International Congress adopted:

In ratifying this proposal the Optical Society of America understands that the intent of this recommendation is as follows:

1. The intention is to specify two things $(a)$ the unit in which the intensities of light sources are to be expressed, and $(b)$ the quality of light to be used.

2. The unit is to be the international candle, implying further that the intensities measured and stated will be luminous intensities as in visual photometry.

3. The quality of light to be used for sensitometry of negative materials is to be that which results from passing the radiation from a grey body at $2,360^{\circ} \mathrm{K}$. normally through the filter described.

4. The grey body and the selectively absorbing filter, together shall be considered as the effective source in specifying the intensity (candlepower).

5. The procedure recommended for determining the intensity of the combined effective source is to multiply the intensity of the primary source (grey body) by the appropriate transmission factor of the filter which is 0.135 . This factor has been computed from the spectral transmission of the filter via the relative energy distribution of $2,360^{\circ} \mathrm{K}$. and the relative visibility function adopted by the sixth session of the International Commission on Illumination at Geneva, 1924 .

6 . This resolution does not state or imply the value of illumination to be used at the test plane during the sensitometric exposure, nor does it place any limitations on the intensity of the light source to be used.

\section{(b) COMMENTS ON USE OF THE FILTERS}

The essential details regarding the preparation of the filters are given in Section IX.

It is the custom to use low-intensity light sources (1 to 20 c. p.) for photographic sensitometry. Several lamps should be available, calibrated by one of the standardizing laboratories at $2,360^{\circ} \mathrm{K}$. Lamps of small candlepower should be calibrated in terms of amperes (with potentiometer control) rather than volts. The filaments should be of such shape and dimensions as to approximate as nearly as possible a point source. The cylindrical or $T$ type of bulb is to be preferred in gas-filled lamps, because the blackening which takes place with use in such lamps occurs mostly at the top where it does not interfere with the light taken in a horizontal direction.

These filters were designed to be used at a temperature of $25^{\circ} \mathrm{C}$. where the highest accuracy is desired. However, a departure of $5^{\circ}$ or $6^{\circ}$ either way is of little or no importance in sensitometry. The effect of temperature is discussed in Section VII, 4. To avoid excess absorption of heat from the lamp by the filter, particularly when large lamps are used, the filter may be placed in the sensitometer with the light shutter between it and the light source. Thus the

16 The official proceedings had not been published at the time the matter was considered by the optical society and the clarifying word "filtered" in the third line of the resolution was not present in the copy of the resolution at hand. 
filter would be exposed to the radiant energy from the lamp only during the sensitometric exposure. It is also recommended that the side of the filter holding the B solution be placed facing the light source, thereby protecting the A solution, the most important one, from undue heating by the lamp.

\section{IN COLORIMETRY}

(a) NEUTRAL STIMULI

If the Planckian radiant energy at some temperature between $3,500^{\circ}$ and $10,000^{\circ} \mathrm{K}$. is eventually adopted as a standard neutral stimulus or white light, a filter converting $2,848^{\circ} \mathrm{K}$. to this color is available from the filters of Series II, Table 12 and charts 21 to 31 . If mean noon sunlight or sunlight outside the atmosphere, the latter representing average daylight, be adopted as standard white, the filters of Series I or the sun-outside-earth's-atmosphere filter (chart 32) are available. A filter (chart 33) duplicating the color of AbbotPriest sunlight is also a vailable.

As an aid in determining the true subjective white, the filter described in chart 38 and Table 15, has been devised, by which any color temperature from approximately $4,000^{\circ}$ to $19,000^{\circ} \mathrm{K}$. may be obtained by varying the color temperature of the source from $2,000^{\circ}$ to $3,100^{\circ} \mathrm{K}$. The use of this filter for this purpose is planned by Priest.

\section{(b) METHODS FOR MEASURING THE COLOR OF NATURAL SUNLIGHT AND}

\section{DAYLIGHT}

A knowledge of the color of sunlight and daylight is of great importance both in photographic sensitometry and in colorimetry, as has already been pointed out. Such knowledge should include information regarding: (1) The variations that may take place both in daylight and sunlight with altitude of sun and with atmospheric conditions, and (2) statistical averages of such data, extensive and reliable enough to serve in the establishment of colorimetric standards of noon sunlight and daylight.

Such information as we have at present comes mostly from the extensive radiometric measurements by Abbot and his coworkers (42) on the spectral energy distribution of sunlight and the transmission of the atmosphere and on various isolated measurements of the color of sunlight and daylight made by Priest $(28,30,43)$ with the rotatorydispersion colorimetric photometer and the leucoscope. The data thus obtained give us an idea of the magnitude of the variations that take place in the color of sunlight and daylight, and serve to locate approximately the statistical averages of these variable colors.

Perhaps the chief reason for the lack of further data on these important subjects is the extreme difficulty of making reliable radiometric measurements and the lack of reliable color standards with which the colors of sunlight and daylight could be compared and measured. The rotatory dispersion colorimetric photometer has so far been the only one devised which can be made up from specification with known spectral characteristics and which is flexible enough to cover approximately the range of colors presented by natural sunlight, daylight, and skylight. This instrument has, however, not been readily available for such purposes. 
Some of the filters already described afford excellent means for the precise measurement of the colors $(r, g$, and $b$ coordinates) of all phases of sunlight and daylight. Inasmuch as the light transmissions of all these filters have been computed, it is also possible to measure illumination at the same time that the color measurements are made.

The following apparatus, in part or in full, in addition to the filters, is required:

1. A lamp calibrated in terms of color temperature (and intensity, if measurements of illumination are to be made). Such calibration need be only at $2,848^{\circ} \mathrm{K}$. for a certain limited group of measurements as explained below. For the complete study of all phases of sunlight and daylight the lamp must be calibrated in terms of voltage or current over the color temperature range from $2,000^{\circ}$ to $3,100^{\circ} \mathrm{K}$. Such calibration may be made by means of the filters, as explained in Sections VI, $2(d)$ and VIII, 5 . The calibration of this working standard lamp, which should be a 500 or 1,000 watt Mazda-C lamp, should be checked from time to time to insure the desired accuracy. For this purpose, a calibrated primary standard Mazda-B lamp should be used, the checking being carried out via the filters in the same manner as the original calibration.

2. A good comparator or photometer by which the light from the sun or sky may be compared with that from the source-and-filter combination. A Martens photometer is especially good for this purpose. Both the natural and artificial sunlight or daylight should be diffused from identical pieces of magnesium carbonate or oxide or other suitable white diffusing material and the diffused light taken into the photometer. The usual precautions regarding stray light should be taken. If, in calibrating the working standard, the primary standard lamp is on that side of the photometer later taken by the natural sunlight or daylight, the method becomes a substitution method.

3. Auxiliary filters for compensating small color differences. While perfect color matches may occasionally be observed between the natural and artificial sunlight or daylight, there will, in general, be slight color differences remaining when the two fields are matched as closely as possible either by change of filter or by adjustment of the color temperature of the source. Such residual color differences may be easily eliminated by the use of Lovibond ${ }^{17}$ glasses of low denomination. Where the color temperature of the source is varied, red (magenta) glasses only are necessary; otherwise, yellow or blue

${ }_{17}$ The Lovibond glasses consist, as indicated above, in a set of red, yellow, and blue glasses. The glasses of any one of the three series give colors of approximately constant hue, but of varying saturation and brilliance. Each of the red, yellow, and blue series of glasses is graded by the makers from 0.01 to 20.0 . The 0.01 glass has very little absorption and its color is barely perceptible, while the 20.0 glass absorbs strongly in certain regions of the spectrum and gives a color of high saturation. The range from 0.01 to 20.0 is subdivided into a large number of steps, there being 155 glasses in each series (465 in all in a complete set of the three series) arranged and numbered in order of increasing saturation. By combining glasses of the same or different series, nearly all colors can be matched, especially if independent means is available for varying the brilliance. The glasses are prepared and sold by The Tintometer (Ltd.), Salisbury, England, and may be also obtained through importers. A descriptive advertising circular is issued by the makers.

The glasses of a given series are supposed to be additive; that is, $10.0+1.2=11.0+0.2=4.4+6.8$, etc. There are certain inaccuracies in the scales, however, which have caused annoyance and error in their use and which have led to insistent demands that the bureau standardize the Lovibond glasses. The work which the bureau has done in this respect is partially described in the following publications: Gibson, Harris, and Priest, A Spectrophotometric Analysis of the Lovibond Glasses, B. S. Sci. Paper No 547; 1927. Judd and Walker, A Study of 129 Lovibond Red Glasses with Respect to the Reliability of their Nominal Grades, Oil and Fat Industries, 5, pp. 16-26; January, 1928. Priest, Judd, Gibson, and Walker, Calibration of Sixty-five 35-Yellow Glasses, B. S. Jour. Research, 1 (R P 58), pp. 793-819; April, 1929. 
glasses may also be required. This is indicated more specifically below. The colorimetric loci of the fractional Lovibond glasses are illustrated in Figure 20, wherein are shown also the black-body locus and the locus of the $2,848^{\circ} \mathrm{K}$.-to-sun-outside-atmosphere filter obtained by varying the color temperature of the source. The coordinates $r$ and $g$ are used in this figure, as least perceptible color differences in any direction are more nearly proportional to distances

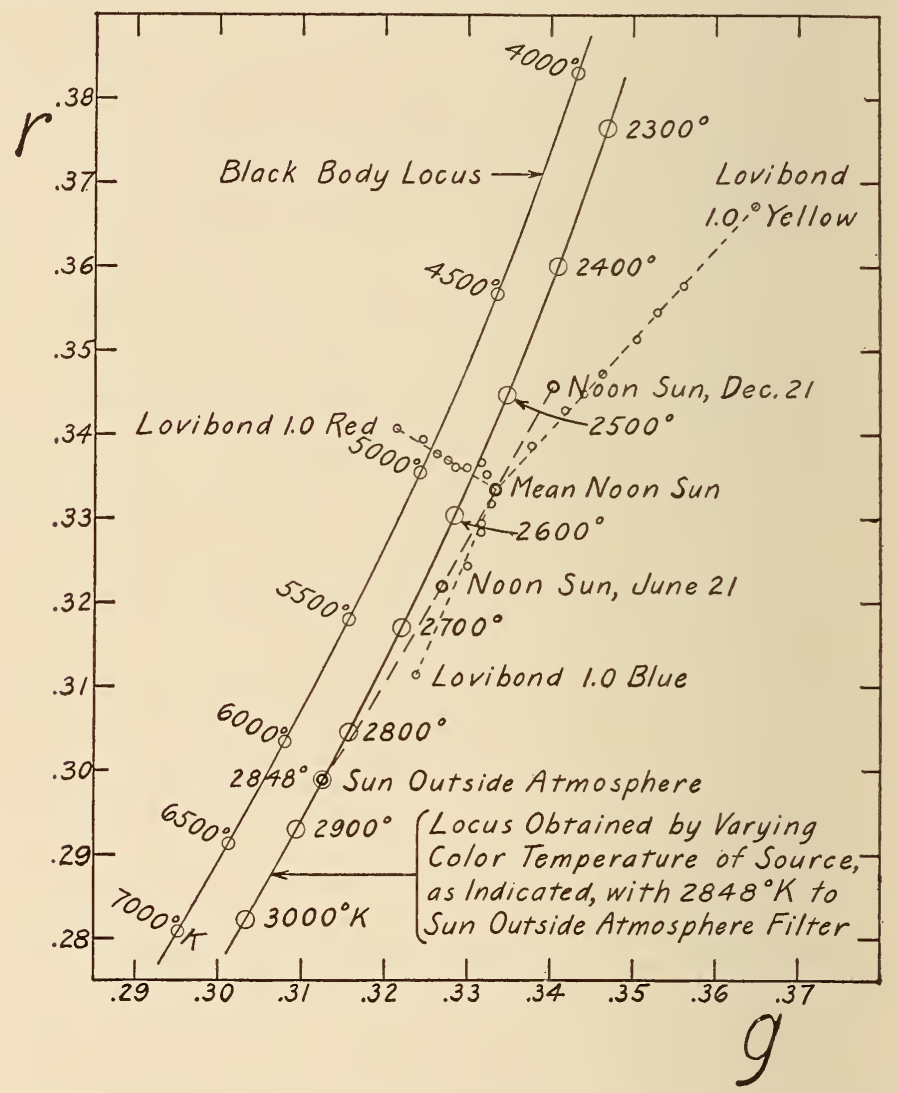

FIGURE 20.-Section of the $r-g$ diagram showing colorimetric positions of Lovibond glasses of low denomination which may be used with certain of the filters in determining the color of sunlight and daylight (See Sec. VI, 2, (b) for details)

The Lovibond glasses shown (B. S. 9940) have the following maker's numerals: Red 1.0,0.70, 0.54, 0.40,0.32,0.26, 0.19, 0.09; Yellow 1.0, 0.70, 0.60, 0.50, 0.40, 0.30, $0.20,0.10$; Blue $1.0,0.50,0.30,0.20,0.10$.

on this scale than on the $r-b$ scale. A comparison of this figure with Figure 17 will illustrate the differences in plotting in the two cases.

The effect of temperature change on the filters should not be ignored. This is discussed in Sections VII, 4 and VIII, 2, $(d)$. If a 500 or 1,000 watt lamp is operated in close proximity to the filter, the temperature of the filter will rapidly increase. This may, in general, be prevented by turning off the lamp or interposing a shutter except during the actual observations and by placing a water cell between 
the lamp and filter. The color of the latter may be ignored if made of borosilicate crown glass as specified for use in the filter, as illustrated in Section VIII, 2, $(d)$.

The following combinations of source and filter may be used in the study of the color of sunlight and daylight.

(1) Source Calibrated at 2,848 $\mathrm{K}$. only.-The following filters are available:

(a) $2,848^{\circ} \mathrm{K}$. to sun outside earth's atmosphere, chart 32 ; (b) $2,848^{\circ} \mathrm{K}$. to mean noon sun at Washington, chart 8 ; (c) $2,848^{\circ} \mathrm{K}$. to noon sun at Washington on June 21 , chart $34 ;(d) 2,848^{\circ} \mathrm{K}$. to noon sun at Washington on December 21 , chart 35 ; and $(e) 2,848^{\circ} \mathrm{K}$. to Abbot-Priest sun, chart 33-all as based on Abbot's data of 1917 . On the basis of direct examination of daylight and noon sunlight made with filters $(a)$ and $(b)$ in September, 1928, and with filters $(a)$ and $(d)$ in December, 1928, the locus of colors represented by the first four filters is slightly greenish relative to the natural sunlight and daylight. Exact color matches may be obtained, however, by inserting Lovibond glasses of low denomination in combination with the source and filterred alone, or red with blue, or red with yellow, depending on atmospheric conditions. This method was used in securing the data illustrated in Figure 32. The Lovibond glasses required varied from about 0.10 to 1.0 in each of the three colors. They were of known spectral transmission and thus of known $r, g$, and $b$, so that the colorimetric values may be derived from the measurements.

The same sort of measurements could be made, using filters of Series II; for example, $2,848^{\circ}$ to $5,000^{\circ}, 5,500^{\circ}, 6,000^{\circ}$, or $6,500^{\circ} \mathrm{K}$. On the basis of the measurements referred to above, the black-body locus is slightly purplish relative to the color of natural daylight and noon sunlight so that combinations of yellow and blue glasses should give the desired color match.

(2) Source calibrated over range from $2,300^{\circ}$ to $3,000^{\circ} \mathrm{K}$.- -The most objectionable feature of the previous method is the necessity for the use of so many Lovibond glasses. If, however, the color temperature of the source may be varied, exact matches may be made with the red glasses only. If the color temperature of the source is varied, in the case of the filter for converting $2,848^{\circ} \mathrm{K}$. to sun outside atmosphere (chart 32) the resulting locus of colors falls very close to that of the natural daylight and noon sunlight, crossing apparently at a slight angle, so that when perfect matches are not obtainable by varying only the source they may be obtained by inserting a red glass, usually of very low denomination, on one side or the other of the photometer. The values of $r, g, b$, the approximate color temperatures, and the light transmissions of this filter with varying source are all given in Table 13 .

On the basis of the observations made in September and December, 1928 (fig. 32), this method is better than that of (1) above, or (3) below for the study of daylight and noon sunlight, although method (1) was used in securing the data illustrated. The only Lovibond glasses required are red glasses having maker's numerals of about $0.1,0.2,0.4$, unless glasses less than 0.1 are desired for distinguishing extremely minute color differences. It is an interesting coincidence that the locus of colors obtainable with this filter passes almost exactly through the point representing the color of Abbot-Priest sun, so that, as previously noted, the latter color may be secured 
not only with a $2,848^{\circ} \mathrm{K}$. source and the filter described in chart 33 , but also with a $2,567^{\circ} \mathrm{K}$. source and the filter described in chart 32 .

(3) Source calibrated over range from $2,000^{\circ}$ (or below) to $3,100^{\circ}$ $K$.-By means of the two filters designed as outlined in Section $\mathrm{V}, 6(e)-\mathrm{viz}, 2,450^{\circ}$ to $3,500^{\circ} \mathrm{K}$. and $2,450^{\circ}$ to $6,500^{\circ} \mathrm{K}$.- and by practically the same method as outlined under (2) just above, the colors of sunlight at practically any altitude, of daylight, and of blue sky may be determined. In addition to the Lovibond red glasses, the use of one or two blue glasses would eliminate the necessity of operating the lamp at the highest temperatures in measuring the color of blue sky. Data on these filters are given in charts 37 and 38 and in Tables 14 and 15.

(c) STANDARDS FOR GRADING DAYLIGHT GLASSES AND ARTIFICIAL WHITELIGHT ILLUMINANTS

That there is need for a ready means of checking the color of socalled "daylight" illuminants has been pointed out in a paper already referred to (17). The manufacturer of such lighting units or of daylight glass should also have available a means of calibrating or grading the material which he is selling. Such a means is available in the filters of the present paper.

He can take his choice of mean noon sunlight (the filters of Series I, charts 1 to 20), average daylight or overcast sky (chart 32), AbbotPriest sunlight (chart 33), or any one or more of the color temperatures from $3,500^{\circ} \mathrm{K}$. (yellowish) to $10,000^{\circ} \mathrm{K}$. (bluish) (the filters of Series II, charts 21 to 31 ) including $6,500^{\circ} \mathrm{K}$., which is close to the color of average daylight. Furthermore, filter No. 38, which by varying the color temperature of the source will give him approximately any color temperature from $4,000^{\circ}$ to $19,000^{\circ} \mathrm{K}$., will enable him to grade any piece of daylight glass or any artificial daylight illuminant at will.

For precise work, a good comparator, such as the Martens photometer, should be used. Simple visual comparison without any instrument will, however, immediately detect any serious deviations from the standard which it is desired to maintain and which is given by any one of the filters that may be selected for that purpose. (d) CALIBRATION OF INCANDESCENT ELECTRIC LIGHTS IN TERMS OF COLOR

By designing the filters of Series I to give an accurate color match with mean sun, and, therefore, with each other, they may be used to calibrate an incandescent electric light in terms of color temperature over the range of the filters, and also, as indicated in the next section, to compare the intensities of two lights of different color temperatures under conditions of perfect color match, thus eliminating some of the uncertainties and difficulties of heterochromatic photometry.

The calibration of a lamp in terms of color temperature is relatively simple provided one has available a good photometer and a lamp already standardized for color temperature over the range to be used. The standardization of a lamp for color temperature has, however, been difficult or impossible for any but a few specially equipped standardizing laboratories. The only instrument for such purposes which is self-contained for its calibration - that is, not dependent for its calibration upon some other calibrated apparatus, other than 
upon a standardized lamp-is Priest's rotatory dispersion colorimetric photometer (30). Blue glass or gelatine wedge photometers, eren if available, are of no fundamental assistance, as they must be calibrated. "Black bodies" are difficult to operate and can not readily be used at the ordinary operating temperatures of the gasfilled tungsten lamp. The usual procedure, if one has wished to secure a lamp standardized for color temperature, has been to obtain such a lamp from the National Bureau of Standards or from some other standardizing laboratory.

The present series of filters will enable one to standardize his own lamp from $2,300^{\circ} \mathrm{K}$. up to as high a temperature as is advisable and furthermore to check such calibration at any time desired. Aside from the filters the sole requisites for such standardization are a source whose color temperature is known at any single temperature within the range of the filters, together with a good photometer. It had been hoped that the acetylene flame might be used as a reproducible source of accurately known color temperature and thus free the worker from any dependence upon the standardizing laboratory. Certain questions have arisen, however, in connection with the acetylene flame (discussed in Section VIII, 6) and, unless approximate values only are desired, it is doubtless preferable to secure a lamp from a standardizing laboratory calibrated at some one temperature and use this as the basic fundamental standard. Color temperatures ol $2,360^{\circ}$ and $2,848^{\circ} \mathrm{K}$. are commonly used reference points, $2,360^{\circ} \mathrm{K}$. being especially favorable as the vacuum tungsten lamp has great constancy both in color and intensity at this color temperature. The following procedure is recommended for the standardization of a lamp over a range of temperatures by means of the filters of Series I:

1. All lamps to be used should be seasoned; that is, operated at normal voltage until they give a constant current at this constant voltage.

2. Upon receipt of the fundamental (primary) standard lamp (standardized at some one color temperature by a standardizing laboratory) secondary working standards should be calibrated in terms of it (without the use of any filters) and thereafter used for the basic color temperature. The primary lamp should never be used except to check the secondary standards.

3. Mean-sun filters should be prepared $(a)$ for the basic temperature of the primary and secondary standard lamps and $(b)$ for as many other color temperatures as are necessary in order to cover the desired range at sufficiently close intervals.

4. It is best to use a substitution method. The working standard and its filter should illuminate one side of the photometric field and a comparison lamp and its filter should illuminate the other. The voltage or current on the comparison lamp should then be varied until an exact color match is obtained in the two parts of the photometric field. The brightnesses in the two halves of the field should be continually matched during that procedure.

5. The particular color temperature chosen at which to operate the comparison lamp is perhaps unimportant. If it is a vacuum tungsten lamp, $2,360^{\circ} \mathrm{K}$. is a suitable temperature. If it is a gas-filled lamp, it should probably be operated at some color temperature near the middle of the range being covered. 
6. The working standard and filter should then be replaced by the lamp being standardized and its voltage or current determined with the various filters prepared for the desired color temperatures.

7. The number of readings taken for the single determinations and the amount of repetition and checking necessary will depend on the observer's skill, his sensibility to color differences, the consistency of the results, and the accuracy desired. A graph of the relation between color temperature and roltage or current of the lamp should have a perfectly regular (smooth) curvature.

8. This lamp being once standardized may be treated as a working standard and other lamps calibrated in terms of it, or several lamps may be standardized at the same time with the same filters.

The question of precision is touched upon in the following section, and a test of the reliability of the filters for color temperature measurements is described in Section VIII, 5.

\section{IN PHOTOMETRY-COMPARISON OF INTENSITIES OF INCANDES- CENT ELECTRIC LIGHTS OF DIFFERENT COLOR TEMPERATURES}

The difficulties and uncertainties of heterochromatic photometry are well known to those engaged in the testing and standardizing of lamps. Even when the uncertainties of attempting to make direct photometric matches of two differently colored lights are eliminated by flicker photometry under standard conditions there still remains the important difference that may result when two observers, both of normal color sense but having different visibility functions, make respective determinations. A difference of sereral per cent may be thus obtained when the candlepower of a gas-filled tungsten lamp is measured relative to that of a racuum tungsten lamp.

The use of the filters would not be convenient where the intensities of lamps of unknown color temperature are desired. But a calibration of intensity for any given lamp over a range of color temperatures may be readily obtained, at the same time as the color temperature calibration described in the previous section if desired, and always with perfect color match in the two parts of the photometric field. Also, of course, any number of lamps, at one or sereral known color temperatures, may be measured relative to a standard lamp operating at some other temperature, all color temperatures being $2,300^{\circ} \mathrm{K}$. or above. The procedure would be very similar to that outlined for the color temperature standardization. The substitution method is even more important in this case. The light transmissions of the filters for their respective sources are given in Table 8 and in the charts.

It may be noted that in the methods of use of the filters as outlined above, both for the determination of color temperature and intensity, various uncertainties entering into the determination of the color and transmission of a filter, and discussed in Sections VII and VIII-viz, possible errors in the spectrophotometric data, possible lack of reproducibility of the chemicals and glass plates, temperature effects, etc.- have a tendency to cancel out, their importance decreasing as the differences in the color temperatures of the sources decrease. These filters should, therefore, have, along with their general applicability for all color temperatures above $2,300^{\circ} \mathrm{K}$, a reliability equal to that obtained with the various special bluish or yellowish filters which have been used to bridge certain steps in the color 
temperature scale of incandescent sources, eren when these latter are carefully calibrated.

The precision of measurement is probably about the same whether filters are used or not, for it has been shown that (30, p. 1191) the precision of determination of the spectral centroid is independent of the color temperature, and also that (44) when the color temperature of a light is changed (for example, by altering the voltage on a lamp), the variation in the spectral centroid of the light transmitted through a white-light filter is slightly greater than the variation in the spectral centroid of the light alone. A real cause for decreased precision might, howerer, be found in the lowered brightness resulting from the use of filters on both sides of the photometer. With most incandescent lights, howerer, intensities are sufficiently great to make this objection of little importance.

An extension of the present series of filters to make them applicable to sources at color temperatures less than $2,300^{\circ} \mathrm{K}$. is impracticable. The lower the color temperature of the source, the less must be the transmission of the filter required to produce artificial sunlight, which has been our objective in designing these filters. This low transmission, combined with the generally low intensities of sources of low color temperatures, would decrease the brightness undesirably. If there were a demand for filters applicable for use below $2,300^{\circ} \mathrm{K}$., a new series could be designed, choosing, not sunlight, but light from the Planckian radiator at some relatively low temperature (say $2,848^{\circ} \mathrm{K}$.) as the light to be delivered by the source-and-filter combination. With this objective, practicable filters could be computed for use in combination with sources at temperatures from below $2,000^{\circ}$ to above $2,300^{\circ} \mathrm{K}$.

(Approximate values of color temperature from $2,000^{\circ}$ to $2,300^{\circ}$ $\mathrm{K}$. may be obtained by use of the $2,450^{\circ}$ to $3,500^{\circ} \mathrm{K}$. filter. For example, from Table 14 it may be noted that color temperatures of $2,649^{\circ}, 2,829^{\circ}$, and $3,012^{\circ} \mathrm{K}$. result when this filter is used with source at $2,000^{\circ}, 2,100^{\circ}$, and $2,200^{\circ} \mathrm{K}$., respectively. A lamp may be calibrated for $2,649^{\circ}, 2,829^{\circ}$, and $3,012^{\circ} \mathrm{K}$. by means of the filters of Series I as illustrated above. To calibrate a lamp for color temperatures of $2,000^{\circ}, 2,100^{\circ}, 2,200^{\circ} \mathrm{K}$., and other values between $2,000^{\circ}$ and $2,300^{\circ} \mathrm{K}$., it is merely necessary to vary the voltage on this lamp until its color viewed through the $2,450^{\circ}$-to- $3,500^{\circ} \mathrm{K}$. filter is matched with that of a bare gas-filled tungsten lamp calibrated at the appropriate color temperatures by means of the filters of Series I. The values thus obtained may be somewhat uncertain because of the lack of exact match between the black-body color and that of the source-and-filter combination at these low color temperatures.) (Fig. 18.)

\section{IN ASTRONOMY-DETERMINING THE COLOR TEMPERATURES OF THE STARS}

The two filters described in Sections V, $6(e)$, together with a calibrated light source, whereby color temperatures from $2,000^{\circ} \mathrm{K}$. or below up to $19,000^{\circ} \mathrm{K}$. may be obtained, should furnish a simple means of accurately determining the color temperatures of the stars. Aside from the usual astronomical equipment, the essential apparatus would consist of a suitable comparator, the two filters, and a lamp calibrated over a color temperature range from $2,000^{\circ}$ to $3,100^{\circ} \mathrm{K}$. with its accompanying voltmeter or ammeter. 


\section{SPECTROPHOTOMETRIC DATA}

\section{APPARATUS AND METHODS}

(a) VISUAL METHOD

Except for some of the preliminary measurements not reported quantitatively in the paper, all spectrophotometric measurements were made in the colorimetry section of the bureau. The larger part of the measurements were made visually with the KoenigMartens spectrophotomoter and auxiliary equipment. A description of this apparatus and method of use is given in a recent publication (45). In the present measurements the instrument has been used in two ways:

1. For the measurements leading to the standardization of the absorbancy and transmittancy values for the standard component solutions (medium concentrations) and the density and transmission values for the double cell filled with distilled water, both the homogeneous $(\mathrm{Hg}$ and $\mathrm{He}$ ) light sources and the heterogeneous (incandescent Mazda C) light source were used, the former, in general, at the eight wave lengths noted below, with $0.5 \mathrm{~mm}$ slits, and the latter over the range from $420 \mathrm{~m} \mu$ or $450 \mathrm{~m} \mu$ to $650 \mathrm{~m} \mu$ or $710 \mathrm{~m} \mu$, usually at every $10 \mathrm{~m} \mu$ and with $0.2 \mathrm{~mm}$ slits (except at the ends of this range where wider slits are usually necessary).

2. For the studies of permanence,-reproducibility, temperature effect, Beer's law, variation of pyridine content, and various miscellaneous measurements these eight wave lengths-viz, $\mathrm{Hg} 404.7, \mathrm{Hg}$ 435.8, $\mathrm{Hg} 491.6, \mathrm{He} 501.6, \mathrm{Hg} 546.1, \mathrm{Hg} 578.0, \mathrm{He} 587.6$, and $\mathrm{He}$ 667.8 -in whole or in part, plus various intermediate wave lengths with the incandescent light if necessary, have furnished sufficient data for the information desired. The obvious advantage in their use is that differences in values obtained in a study of the various effects can not be ascribed to wave-length or slit-width errors. Furthermore, they cover the most important part of the wave-length range used in the present investigation. Various details concerning the measurements are noted later in the sections devoted to the respective subjects.

(b) AUXILIARY METHODS

Supplementing the visual method in the determination of the spectrophotometric data on the standard component solutions, thermoelectric, photoelectric, and photographic methods were used. The thermoelectric and photoelectric methods have been described elsewhere (46). The former was used over the range from $610 \mathrm{~m} \mu$ or $650 \mathrm{~m} \mu$ to $750 \mathrm{~m} \mu$ or $780 \mathrm{~m} \mu$, at every $10 \mathrm{~m} \mu$ or $20 \mathrm{~m} \mu$, depending upon the type of transmittancy, thus overlapping the visual method at several wave lengths. The photoelectric method was used over the range from $390 \mathrm{~m} \mu$ to $510 \mathrm{~m} \mu$ or $550 \mathrm{~m} \mu$, likewise at every $10 \mathrm{~m} \mu$ or $20 \mathrm{~m} \mu$, thus overlapping the visual method for an extensive range in the blue and green.

The photographic (Hilger sector photometer) method was used essentially as previously described $(47,48)$, except that for part of the measurements a ribbon-filament Mazda C lamp was used as source instead of the underwater spark. The primary purpose in the use of this method was to extend the data from the visible to $350 \mathrm{~m} \mu$. It was used not only for the standard component solutions, but also in the study of Beer's law. 
(c) MISCELLANEOUS

The thicknesses of cell used in the spectrophotometric determinations were $10,20,40$, and $100 \mathrm{~mm}$, these being accurate to one-tenth of 1 per cent or better. The particular thickness used in any case depended on the solution and the purpose of the measurements. Sometimes but one thickness, sometimes three or four thicknesses were used during a set of measurements on any given solution. The particular ones used will not, in general, be further stated. Regardless of the thickness used, values were always computed to $10 \mathrm{~mm}$, inasmuch as this is the standard thickness used in the filters described herein.

The temperature of the solutions was in all cases kept at $25^{\circ} \pm 1^{\circ}$ C., unless otherwise noted. The apparatus for all four methods of measurement includes temperature control for solutions. This has been previously described $(45,47)$.

The concentrations given throughout this section are accurate to $0.001 \mathrm{~g}$, and the volumes to $0.1 \mathrm{cc}$ (except in the case of $1,000 \mathrm{cc}$ or 1 liter, where $0.1 \mathrm{cc}$ is not significant), whether indicated by the proper number of significant figures or not.

\section{STANDARD FILTER COMPONENTS}

In Tables 4, 5, 6, and 7 (Sec. V, 2) are given values of the density of the double cell with water, and of the absorbancy of the standard solutions $\mathrm{A}^{\prime}, \mathrm{B}_{1}{ }^{\prime}$, and $\mathrm{B}_{2}{ }^{\prime}$ as adopted for the present investigation. A precise description of the cell and of the solutions is given in Section IV, 1.

An outline of the experimental procedure, by means of which these data were obtained, follows. The final use of the data was, of course, kept in mind throughout the measurements. While it was convenient and desirable in view of the various computations, to consider the fundamental spectrophotometric data in terms of absorbancy (the slide rule used in the visual measurements on the Koenig-Martens spectrophotometer contained $a-\log _{10}$ scale, so that values of absorbancy were obtained directly from the readings of the spectrophotometer and not via a previous transmittancy computation), it is ultimately the transmittancy values, entering into the final transmission of the cell and its contents, comprising any given filter, which is of importance; for it is the product of transmission of the filter by the energy of the light source that gives the energy distribution of the source-andfilter combination. A difference or error in absorbancy of 0.00434 means a difference or error in transmittancy amounting to 1 per cent of the transmittancy, regardless of the values of absorbancy and transmittancy. Consequently it was never attempted to reach a constant percentage accuracy in the absorbancy data; that is, if $\Delta A$ represents the uncertainty in the values of $A$, it was never attempted to make $\frac{\Delta A}{A}$ constant regardless of $A$. It was attempted, rather, to maintain $\Delta \mathrm{A}$ constant, less than 0.00434 so far as possible, so that $\frac{\Delta T}{T}$ should be constant and not greater than 1 per cent. A discussion of the reliability of the various data is given later.

In view of the uncertainty in the absorbancy caused by filtering the A solution through filter paper, it was, as elsewhere noted, decided 
to base all standard adopted data on unfiltered solutions. This point is of little importance in the case of the $\mathrm{B}$ solution, but is not negligible with the $A$ solution. All the spectrophotometric data given in this paper, unless otherwise specifically noted, were obtained with unfiltered solutions. In using the solutions during the measurements care was taken not to shake or tip the bottles unduly, and the solutions were transferred from bottle to cell usually by means of a pipette. The reason for this is that all chemicals contain a minute quantity of trash or insoluble material which settles to the bottom upon standing.

\section{(a) TWO-COMPARTMENT GLASS CELL WITH DISTILLED WATER}

Measurements were made by the risual method from $460 \mathrm{~m} \mu$ to $720 \mathrm{~m} \mu$ in addition to the $\mathrm{Hg}$ ware length $404.7 \mathrm{~m} \mu, 435.5 \mathrm{~m} \mu, 491.6 \mathrm{~m} \mu$, $546.1 \mathrm{~m} \mu$, and $578.0 \mathrm{~m} \mu$. Photoelectric measurements were made from $400 \mathrm{~m} \mu$ to $580 \mathrm{~m} \mu$ and thermoelectric measurements from $640 \mathrm{~m} \mu$ to $780 \mathrm{~m} \mu$. In addition, measurements were made br R. Stair, of the radiometry section of the bureau, by the thermoelectric method, at the $\mathrm{Hg}$ ware lengths $436 \mathrm{~m} \mu, 405 \mathrm{~m} \mu, 365 \mathrm{~m} \mu, 334 \mathrm{~m} \mu, 313 \mathrm{~m} \mu, 305 \mathrm{~m} \mu$, and $280 \mathrm{~m} \mu$.

The adopted ralues of density and transmission are giren in Table 7 (see also fig. 10), those below $400 \mathrm{~m} \mu$ being based primarily on Mr. Stair's data. The uncertaintr in the absolute ralues of transmission might be $=1$ per cent, considering the spectrophotometric data alone, although the relative accuracr is better than this. However, the value of transmission computed from the refractive indices of the glass and water, assuming no absorption, is equal to 0.904 , and a ralue of 0.906 was reported br the optical instrument section for the "white light" transmission. "The values of transmission in Table 7 are, therefore, considered accurate to $=0.5$ per cent or better, as the spectral transmission orer the range of highest luminosity raries from 0.900 to 0.904 .

The water absorption band at $750 \mathrm{~m} \mu$ is plainly shown. The slight absorption shown by the remaining data in the visible, and rapidly increasing in the ultra-riolet, is ascribed mostly to the glass.

\section{(b) SOLUTION A'}

An outline of the experimental work leading to the adoption of this combination of materials for the principal (blue) solution has been giren in Section IV, 1. Haring decided on the most suitable amounts of copper sulphate and prridine, riz, $3.000 \mathrm{~g}$ and $30.0 \mathrm{cc}$, respectirely, but without mannite as ret, spectrophotometric measurements were made by the risual, thermoelectric, and photo-electric methods, corering the range from $390 \mathrm{~m} \mu$ to $750 \mathrm{~m} \mu$. Talues of absorbancs for $10 \mathrm{~mm}$ thickness at ererr $10 \mathrm{~m} \mu$ from $390 \mathrm{~m} \mu$ to $750 \mathrm{~m} \mu$ were adopted from these measurements (Mar, 1926). Ther refer to a single solution, No.61-11, the measurements being made within a few dars after preparation. After the hot summer weather had shown the copper-sulphate-prridine solutions to be rather unstable at temperatures between $35^{\circ}$ and $40^{\circ} \mathrm{C}$. and mannite had been added as an essential constituent of these blue solutions, measurements of absorbancy were repeated, similar to but more extensire than those of May, 1926. New ralues of absorbancy were thereupon adopted 
(October, 1926). They refer to solution No. 62-2, the data being taken from 3 to 32 days after preparation of solution. Certain small but fairly definite discrepancies which were more or less a function of time became apparent during these measurements. These were at first considered as a turbidity effect, but later work has proved them mostly a result of the very slow change in absorbancy which takes place with time. (This characteristic of the A solution is discussed in Section VII, 3.)

Another solution was thereupon prepared, No. 62-15. The eight reference wave lengths previously noted-viz, $\mathrm{Hg} 404.7 \mathrm{~m} \mu, \mathrm{Hg}$ 435.8m $\mu, \mathrm{Hg} 491.6 \mathrm{~m} \mu, \mathrm{He} 501.6 \mathrm{~m} \mu, \mathrm{Hg} 546.1 \mathrm{~m} \mu, \mathrm{Hg} 578.0 \mathrm{~m} \mu, \mathrm{He}$ $587.6 \mathrm{~m} \mu$, and He $667.8 \mathrm{~m} \mu$-were the only ones used in the study of this new solution. Measurements were made on the day of preparation and on the first, second, sixth, eighth, twenty-third, and twentyfourth days after preparation. The changes that took place from the sixth to the twenty-fourth day were all less than 1 per cent of the transmittancy.

Based principally on the average of these measurements from the sixth to the twenty-fourth on solution No. 62-15, and guided also by miscellaneous measurements at these wave lengths on other $A^{\prime}$ solutions, values of absorbancy were adopted (Nov. 19, 1926) which are the values listed at the bottom of Table 4. A summary of all the experimental data obtained with the eight $\mathrm{Hg}$ and $\mathrm{He}$ wave lengths on the various $\mathrm{A}^{\prime}$ solutions is given in Table 18.

The data of October, 1926, were then adjusted so that the data of November 19, 1926, would lie precisely upon the curve drawn through the adjusted values. These adjusted values of absorbancy (adopted Nov. 30, 1926) are the ones given in Table 4 from $400 \mathrm{~m} \mu$ to $750 \mathrm{~m} \mu$ (see also fig. 10). The finally adopted spectral absorbancy values of November 30, 1926 (with mannite) differed from the original data of May, 1926 (without mannite), in no case by more than 0.005 . There is no reason to think that mannite influences the transmittancy of the copper-sulphate-pyridine solutions except to make them much more stable.

During February, 1927, measurements were made photographically (solution No. 65-5, seven days after preparation), overlapping the adopted data of November, 1926 , from $400 \mathrm{~m} \mu$ to $510 \mathrm{~m} \mu$ and extending into the ultra-violet beyond $350 \mathrm{~m} \mu$. The agreement with the adopted values above $400 \mathrm{~m} \mu$ was satisfactory. The values given in Table 4 from $350 \mathrm{~m} \mu$ to $390 \mathrm{~m} \mu$ were obtained from these measurements on solution No. 65-5, taking a graphic average of the data for 10,20 , and $40 \mathrm{~mm}$ thickness, all reduced to $10 \mathrm{~mm}$ as usual. These data were closely checked by later measurements on solution No. 65-8-C, 20 days after preparation, made during the study of Beer's law from $350 \mathrm{~m} \mu$ to $400 \mathrm{~m} \mu$.

\section{(c) SOLUTION $\mathrm{B}_{1}^{\prime}$}

As previously stated, $20.000 \mathrm{~g}$ of copper sulphate per liter of acidified aqueous solution was chosen as standard. A filtered solution was prepared, No. 62-1, and spectrophotometric measurements made by visual, thermoelectric, and photoelectric methods during the first month after preparation. Values of absorbancy from $390 \mathrm{~m} \mu$ to $750 \mathrm{~m} \mu$ were thereupon adopted (September, 1926). These values were checked closely by the measurements made in the test of Beer's 
law (solutions Nos. 62-7-A to E, filtered, October, 1926), but were revised somewhat in the red on the basis of later measurements.

After the decision had been made not to use filtered solutions, an unfiltered solution, No. 62-5, was prepared. A single set of measurements at the $\mathrm{Hg}$ wave lengths (see Table 19 for summary of measurements made with $\mathrm{Hg}$ and $\mathrm{He}$ wave lengths on the $\mathrm{B}^{\prime}{ }_{1}$ solutions), made on the second day after preparation and using $100 \mathrm{~mm}$ cells, showed a very distinct decrease in transmittancy compared with the values previously obtained with filtered solutions, although this amounted to less than 1 per cent when reduced to a $10-\mathrm{mm}$ basis. This discrepancy was considered a turbidity effect and it was decided to study the change with time in a manner similar to that described for the $A^{\prime}$ solution, No. 62-15.

Accordingly, a new solution was prepared, No. 62-18, unfiltered, and measurements made on the day of preparation and on the first, fourth, twelfth, and fourteenth days after preparation, using the eight $\mathrm{Hg}$ and $\mathrm{He}$ wave lengths. It was found (Table 19) that the measurements made during the first four days after preparation checked those made on No. 62-5, unfiltered, made the second day after preparation, and that the measurements made on the twelfth and fourteenth days checked closely with the measurements made on the filtered solutions Nos. 62-1 and 62-7-C. Apparently, then, the insoluble matter causing the turbidity settles to the bottom of the bottle after the first few days and is removed entirely by filtering. Measurements on solution $\mathrm{B}^{\prime}$ (below) show that no further change of any importance takes place. With $\mathrm{B}_{1}$ solutions, therefore, there is no practical difference between filtered and unfiltered solutions, provided the latter are not used for a week or so after preparation and care is taken not to disturb the insoluble material at the bottom of the bottle.

Based partially on the measurements with solution No. 62-18, particularly the data for 12 and 14 days after preparation, and also on the other measurements noted, absorbancy data for the $\mathrm{Hg}$ and $\mathrm{He}$ wave lengths were adopted (Nov. 13, 1926) and are given at the bottom of Table 5. Particular attention was paid to the He 667.8 measurements, seven different determinations being finally averaged to give the value adopted.

The previous data of September, 1926, were now adjusted to fit these data of November 13, 1926, in a manner similar to that done with solution $\mathrm{A}^{\prime}$. The only important change was in the red. The change required to make the previous data consistent with the $\mathrm{He}$ 667.8 values varied from less than 1 per cent of the transmittancy below $630 \mathrm{~m} \mu$ to about 3 per cent at $750 \mathrm{~m} \mu$. The finally adopted data (Nov. 15,1926 ) from $400 \mathrm{~m} \mu$ to $750 \mathrm{~m} \mu$ are given in Table 5 (see also fig. 10).

Photographic measurements in the ultra-violet to approximately $320 \mathrm{~m} \mu$ were made on $40-\mathrm{mm}$ solutions (No. 65-3, unfiltered) about two weeks after preparation. The absorbancy was too low to obtain any data above $370 \mathrm{~m} \mu$ by this method, but it was not difficult to connect the visible and photographic data by a reasonable curve. The values of absorbancy are so small in this region that they might be considerably in error without affecting the transmittancy by more than a fraction of a per cent. The values from $350 \mathrm{~m} \mu$ to $390 \mathrm{~m} \mu$ in Table 5 were thereupon adopted. 


\section{(d) SOLUTION $B^{\prime}{ }_{2}$}

It has already been noted that cobalt sulphate was at first used instead of the cobalt ammonium sulphate later adopted because of its greater stability. After preliminary measurements had indicated that $10.000 \mathrm{~g}$ of cobalt sulphate per liter was a suitable concentration, an unfiltered solution was prepared, No. 61-10, containing, however, but 4 cc of sulphuric acid. (The exact amount of sulphuric acid is apparently of little, if any, importance.) Measurements were made visually, thermoelectrically and photoelectrically, covering the wavelength range from $390 \mathrm{~m} \mu$ to $750 \mathrm{~m} \mu$. Values of absorbancy were thereupon adopted (May, 1926). Later, after a study of Beer's law had been made, with filtered solutions, Nos. $62-8-\mathrm{A}$ to E containing 10 cc of sulphuric acid, and no deviation from Beer's law detected, the values were revised slightly (October, 1926).

In the latter part of October, 1926, a new solution was prepared, No. 62-17, unfiltered, containing 10 cc of acid, and measurements were made on the day of preparation and on the first, fourth, thirteenth, and fifteenth days after preparation, using the eight $\mathrm{Hg}$ and He reference wave lengths. No change of absorbancy was detected over this interval of time.

Based principally on these measurements on solution No. 62-17, but guided also by the other previous measurements, the absorbancy values given at the bottom of Table 6 were adopted (November 13, 1926). In a manner similar to that for solutions $A^{\prime}$ and $B_{1}{ }^{\prime}$, the revised data of October, 1926, were adjusted to fit these adopted data of November 13, 1926, and the data thus finally adopted (November 17,1926 ) are given in Table $6,400 \mathrm{~m} \mu$ to $750 \mathrm{~m} \mu$ (see also fig. 10). The absorbancy values finally adopted November 17, 1926, differ from those originally obtained in May, 1926, in no case by more than 0.0028 . The data summarized in Table 20 indicate that a turbidity effect, such as was found with copper sulphate, was not present, and it is apparently of no practical importance whether a $B_{2}$ solution is clarified by filtering or by decanting.

The loss of water of crystallization of cobalt sulphate (Sec. IV, 1) led to the analysis of solution No. 62-17, which was found to contain an amount of cobalt equivalent to $10.3 \mathrm{~g}$ of cobalt sulphate instead of $10.0 \mathrm{~g}$ as supposed. The change to cobalt ammonium sulphate was thereupon made. A single set of absorbancy measurements on a cobalt ammonium sulphate solution (No. 62-20) equivalent in cobalt content to $\mathrm{No}$. 62-17, at the eight $\mathrm{Hg}$ and $\mathrm{He}$ wave lengths, agreed with the adopted data of November 13, 1926, to 0.0022 or better. Further test as to the agreement between absorbancy data for cobalt sulphate and cobalt ammonium sulphate was afforded by Beer's law measurements on cobalt ammonium sulphate. The measurements made (at $435.8 \mathrm{~m} \mu, 491.6 \mathrm{~m} \mu, 501.6 \mathrm{~m} \mu$, $546.1 \mathrm{~m} \mu$, and $578.0 \mathrm{~m} \mu$ ) on the solution having the standard concentration (No. 65-1-C) agreed with the adopted values to 0.0015 or better. A more important check, however, was obtained on the mixture of cobalt ammonium sulphate and copper sulphate, as indicated in the next section.

Photographic measurements were made from $450 \mathrm{~m} \mu$ to below $350 \mathrm{~m} \mu$ on cobalt ammonium sulphate as with copper sulphate. The absorbancy is very small below $400 \mathrm{~m} \mu$. Measurements from one to two weeks after preparation were made on solution No. 65-4, 14.481 g, 
and on No. 65-9, approximately $144.81 \mathrm{~g}$, using 40-mm cells in both cases. With the latter solution Beer's law was assumed for computing to $14.481 \mathrm{~g}$. Perfect agreement with the adopted data of Table 6 from $400 \mathrm{~m} \mu$ to $450 \mathrm{~m} \mu$ was not obtained. The differences, however, were not outside the uncertainties of the photographic data. The data were adjusted to fit the adopted values from $400 \mathrm{~m} \mu$ to $450 \mathrm{~m} \mu$ and are given as adopted in Table 6 . Inasmuch as the absorbancy is itself less than 0.01 below $400 \mathrm{~m} \mu$, there is no chance for any important error to be present in the adopted data.

Comparative measurements showed a difference in absorbancy between cobalt sulphate and cobalt ammonium sulphate below $400 \mathrm{~m} \mu$. Cobalt sulphate has a minimum absorbancy at approximately $370 \mathrm{~m} \mu$. For cobalt ammonium sulphate this minimum is shifted to about $355 \mathrm{~m} \mu$, and the values of absorbancy are, in general, lower. As shown elsewhere, however, in the visible spectrum, the differences in transmittancy between cobalt sulphate and the equivalent amount of cobalt ammonium sulphate, at the concentrations used and for 10 $\mathrm{mm}$ of solution, must be considerably less than 1 per cent, if any difference exists at all.

\section{(e) SOLUTION B'}

Solution No. 65-2, unfiltered, was prepared containing $20.000 \mathrm{~g}$ of copper sulphate and $14.481 \mathrm{~g}$ of cobalt ammonium sulphate per liter of acidified aqueous solution. Measurements were made on this solution eight and nine days after preparation, using 10,20,40, and $100 \mathrm{~mm}$ of solution at the eight $\mathrm{Hg}$ and $\mathrm{He}$ wave lengths. The values were reduced to $10 \mathrm{~mm}$ thickness as usual and averaged. The maximum difference between these average observed absorbancies and those computed, adding the absorbancies tabulated for solutions $\mathrm{B}_{1}{ }^{\prime}$ and $\mathrm{B}_{2}{ }^{\prime}$, Tables 5 and 6 , was but 0.0012 , or less than one-third of 1 per cent of the transnittancy. (Table 21.)

In greater concentrations this strict additivity of the components of the $\mathrm{B}$ solution might not hold accurately, but over the range of concentrations used in the various filters, considering also various other spectrophotometric checks (Sec. VIII), it is certain that any error involved in using this additivity is negligible.

As implied in the preceding section, this set of measurements on Solution $\mathrm{B}^{\prime}$ also served as a check on the equivalence of cobalt ammonium sulphate and cobalt sulphate in the visible spectrum, for the latter had been used in adopting the values of Table 6 and the former in the preparation of solution No. 65-2.

\section{PERMANENCE OF SOLUTIONS}

There was no indication of change taking place in the separate copper sulphate and cobalt sulphate solutions, except the very slight turbidity effect noticed with the former, as already described. A much more important question is whether or not the mixture of the copper sulphate and the cobalt ammonium sulphate is unchanging in its transmittancy. Accordingly, when solution $\mathrm{B}^{\prime}$ above described (No. 65-2) was 300 days old, a set of measurements was made, similar to those made 9 days after preparation. The maximum deviation between the two sets of absorbancy values was 0.0028 (Table 21), about two-thirds of 1 per cent of the transmittancy, and no change at all was indicated outside of possible experimental error. 
However, small but definite changes took place in the $\mathrm{A}^{\prime}$ solution with time. The absorbancy measurements on solution No. 62-15, using the eight $\mathrm{Hg}$ and $\mathrm{He}$ wave lengths, have already been noted. These were made on the day of preparation and on the first, second, sixth, eighth, twenty-third, and twenty-fourth days after preparation. Measurements were again made on this solution 384 and 385 days

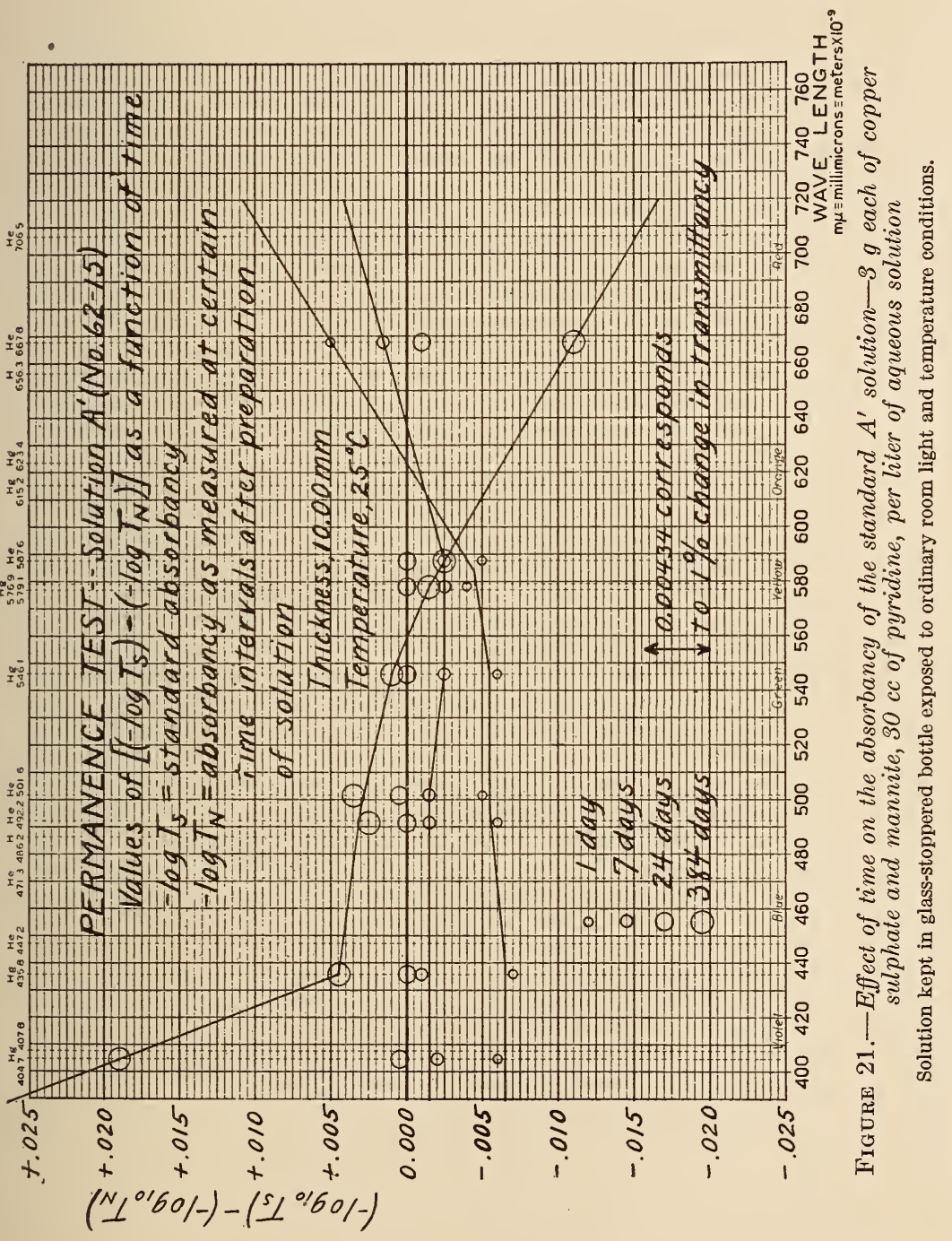

after preparation. The data for 0,1 , and 2 days were averaged together, likewise the data for 6 and 8 days, 23 and 24 days, and 384 and 385 days; so that, in effect, we have data on this solution representative of the first, seventh, twenty-fourth, and three hundred and eighty-fourth day after preparation. These data, given in Table 18 and plotted in Figure 21, show the differences in absorbancy between the data representative of the time intervals as noted and 
the standard values of Table 4 . The change throughout the brighter part of the spectrum is small, but there is a definite decrease in transmittancy in the red and an increase in the violet, resulting in the solution becoming slightly bluer after long standing. However, over a period from a week to a month, probably two months, the values do not deviate from the adopted values by more than 1 per cent of the transmittancy. The resulting effect of this and other factors on the color of completed filters is discussed further in Section VIII.

\section{TEMPERATURE EFFECTS}

As noted elsewhere, the standard temperature adopted for these solutions was $25^{\circ} \mathrm{C}$. and all measurements of transmittancy or absorbancy reported in this paper refer to this temperature unless otherwise specifically noted. It is well known that aqueous inorganic salt solutions may show a relatively rapid change in transmittancy with temperature, whereas aqueous dye solutions are often practically unaffected.

It might, perhaps, have been assumed that any variation of absorbancy thus caused would be proportional to the concentration of the solution for a given temperature range. It seemed best, however, to test this.

\section{(a) SOLUTION A}

Three solutions were prepared (Nos. 65-17-A, 65-18-A, and 65-19-A), having concentrations of copper sulphate (and mannite) equal to $3.707,2.445$, and $0.741 \mathrm{~g}$ per liter, respectively. The pyridine content of each solution was $30 \mathrm{cc}$ per liter, as usual. These concentrations are those used in the $2,360^{\circ}, 2,848^{\circ}$, and $4,000^{\circ} \mathrm{K}$.-tosunlight filters, covering nearly the complete range of concentrations used.

For each concentration, measurements of absorbancy were made at $25^{\circ} \mathrm{C}$, at $40^{\circ} \mathrm{C}$, and again at $25^{\circ} \mathrm{C}$. These measurements were made in December, 1927, from one to two weeks after preparation of the solutions. The eight $\mathrm{Hg}$ and $\mathrm{He}$ wave lengths were used in addition to $460 \mathrm{~m} \mu, 520 \mathrm{~m} \mu, 560 \mathrm{~m} \mu, 610 \mathrm{~m} \mu, 640 \mathrm{~m} \mu, 690 \mathrm{~m} \mu$, and $720 \mathrm{~m} \mu$. The $3.707 \mathrm{~g}$ solution was measured at $10 \mathrm{~mm}$ thickness, the $2.445 \mathrm{~g}$ at $20 \mathrm{~mm}$, and the $0.741 \mathrm{~g}$ at $40 \mathrm{~mm}$.

Values of absorbancy were then reduced to $10 \mathrm{~mm}$ thickness for all three solutions. The two sets of $25^{\circ} \mathrm{C}$. values were averaged and taken to represent $25^{\circ} \mathrm{C}$, , as no permanent change was detected. The differences in absorbancies - that is, $\mathbf{A}_{25^{\circ}}-\mathbf{A}_{40^{\circ}}$ - at the various wave lengths were then taken for each solution, and it was found that at practically every wave length this difference was proportional to the concentration of the solution within the experimental uncertainty.

These values of $A_{25^{\circ}}-A_{40}$ were thereupon divided by the concentration and are plotted in Figure 22. The general lack of any consistent differences in the values computed from the different concentrations shows that any attempt to correct these values on the basis of the Beer's law data already obtained would have been an unwarranted refinement. (The values at $404.7 \mathrm{~m} \mu$, where the Beer's law correction is several times as large as at the other wave lengths, probably illustrate the effect of ignoring such a correction.) 
There are given also in Figure 22 the mean values of $\mathbf{A}_{25^{\circ}}-\mathbf{A}_{40^{\circ}}$ per gram and a curve plotted through the adopted values. These adopted values are given in Table 16, and, with those obtained for solution B, were used in computations of the temperature effect on the completed filters. (Sec. VIII.)

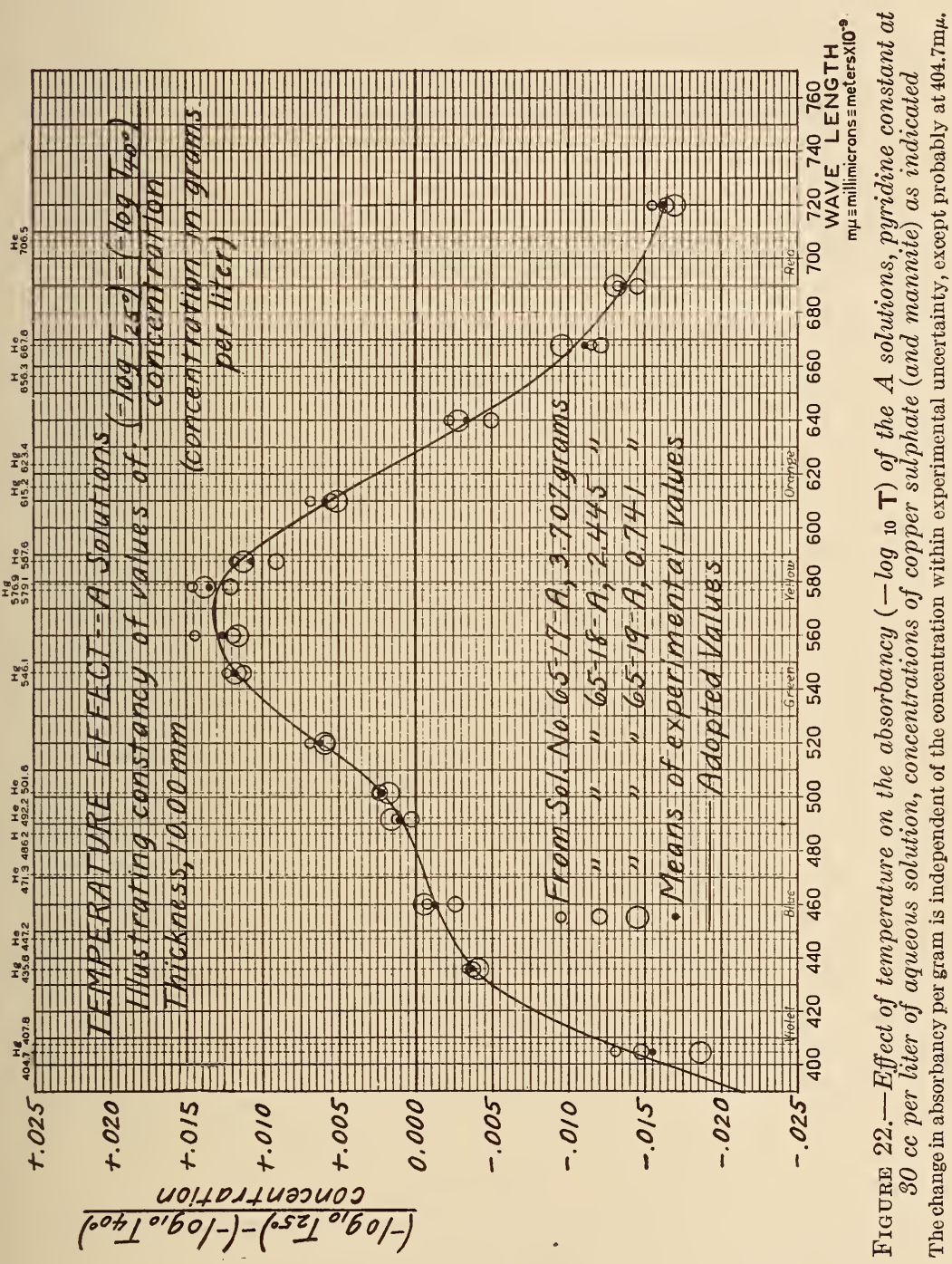

(b) SOLUTION B

The transmittancies of the components of the B solution were known to decrease with increasing temperature. As in the study of permanence, however, the effect should be tested on the B mixture, and not computed from data on the two components, even if such were available in suitable form. Accordingly three B solutions were 
prepared, having concentrations corresponding to the filters $2,360^{\circ}$, $2,848^{\circ}$, and $4,000^{\circ} \mathrm{K}$. to mean sun, viz:

\begin{tabular}{|c|r|r|}
\hline \multirow{2}{*}{ Number } & \multicolumn{2}{|c|}{$\begin{array}{c}\text { Concentration (in } \\
\text { grams per liter) }\end{array}$} \\
\cline { 2 - 3 } & $\begin{array}{r}\text { Copper } \\
\text { sulphate }\end{array}$ & $\begin{array}{c}\text { Cobalt } \\
\text { ammonium } \\
\text { sulphate }\end{array}$ \\
\hline 65-17-B_- & $\begin{array}{r}27.180 \\
65-18-\mathrm{B}_{-} \\
65-19-\mathrm{B}_{-}\end{array}$ & $\begin{array}{r}26.520 \\
6.250\end{array}$ \\
$\begin{array}{r}19.820 \\
1.130\end{array}$ \\
\hline
\end{tabular}

1 This solution was made up with the weights inadvertently reversed from the intended values. The mistake was not aiscovered until after the measurements were completed, but no error or disadvantage results from using the data, the values of absorbancy being applied to the weights as actually used.

The measurements were made in December, 1927, from two to three weeks after preparation of the solutions. Thicknesses of solution of 10,20 , and $40 \mathrm{~mm}$, respectively, were used, and the other experimental conditions were the same as for the A solutions above described.

Previous measurements (49) on a copper-sulphate solution at $57 \mathrm{~g}$ per liter have shown that the change with temperature was inappreciable at the shorter wave lengths, increasing as the absorbancy increased toward the longer wave lengths. It was also known (50, plate 30 ) that the principal temperature change with cobalt sulphate was in the green with little change in the red where the absorbancy is small. Furthermore, the weights of the two components are not greatly different for two of the three solutions.

Accordingly, the values of $A_{25^{\circ}}-A_{40^{\circ}}$ were reduced to a $10 \mathrm{~g}$. basis (in a manner analogous to the $A$ solutions, which were reduced to a $1 \mathrm{~g}$ basis) assuming the change in absorbancy below $600 \mathrm{~m} \mu$ to be caused by the cobalt ammonium sulphate alone and that above $600 \mathrm{~m} \mu$ by the copper sulphate alone. These values are plotted in Figure 23 for two of the three solutions. Values for solution No. 65-19-B are not given. The concentrations were so low that observational uncertainty masked the real effect over most of the range. These data were accordingly not used.

The curve drawn more or less through the average of the values for the two solutions was adopted as representative of the temperature effect on solution B per $10 \mathrm{~g}$ of each component. The separate values derived and estimated from this curve for each component are 
given in Table 16 and plotted in Figure 23. Remembering that 0.00434 is equivalent to a 1 per cent change in transmittancy, such

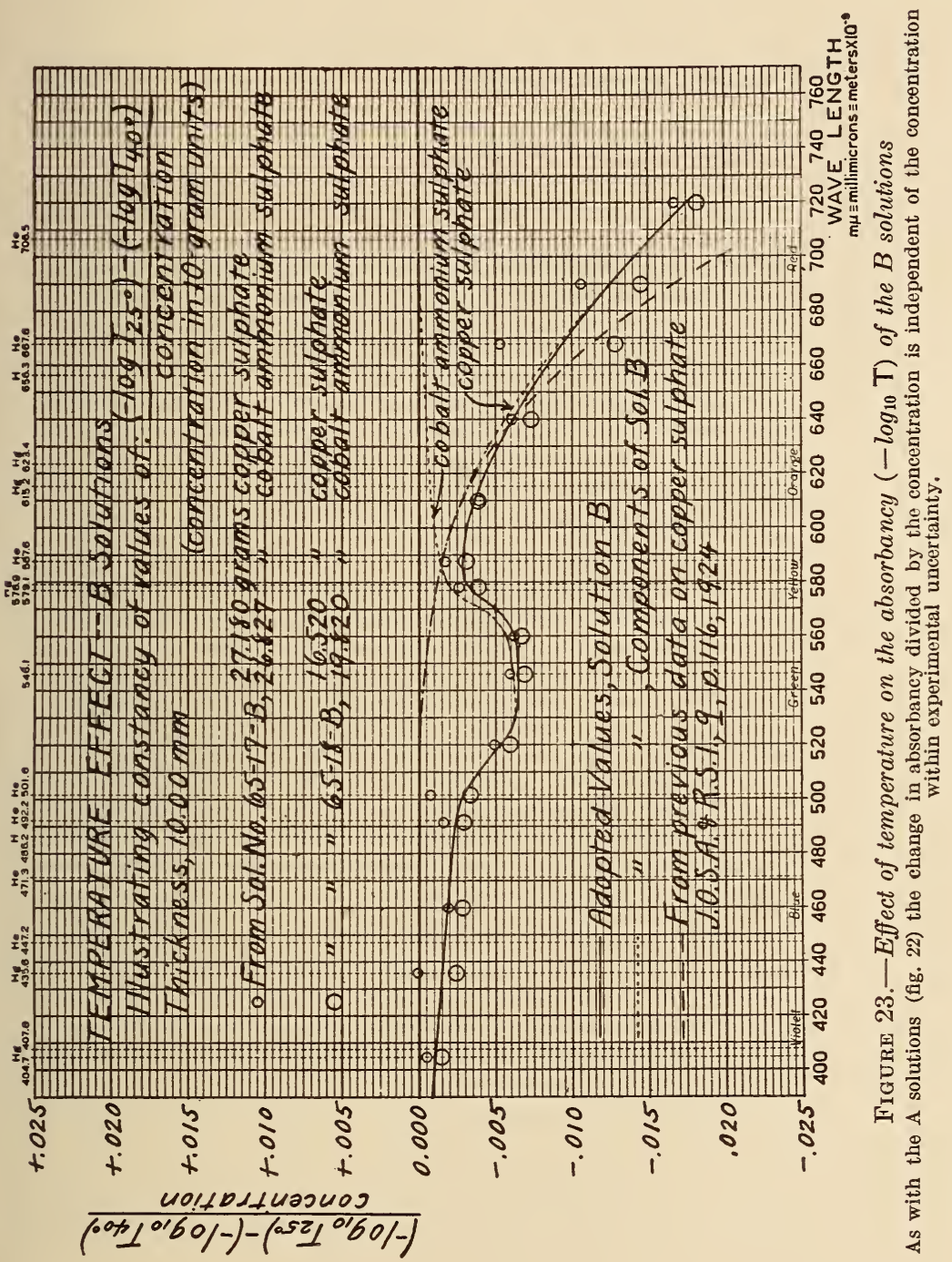

uncertainty as is present in the data is probably negligible. ${ }^{18}$ All the values of Table 16 are considered uncertain in the fourth decimal.

${ }_{18}$ An apparent discrepancy may be noted (fig. 23) between the present data for copper sulphate and the data referred to in a previous publication (49), particularly at wave lengths greater than $650 \mathrm{~m} \mu$. This difference is probably not outside of the possible combined experimental error in the two cases, but may also be caused by the different experimenta! conditions, viz, $57 \mathrm{~g}$ per liter, no acid, no mixture with cobalt ammonium sulphate in the previous determination, as contrasted with the respective differing conditions of the present determination. 
TABLE 16-Changes in absorbancy ${ }^{1}$ with temperature for component filter solutions

\begin{tabular}{|c|c|c|c|c|c|c|c|}
\hline \multirow{2}{*}{$\begin{array}{l}\text { Wave length in } \\
\text { millimicrons }\end{array}$} & \multicolumn{3}{|c|}{ Values of $\frac{A_{250}-A_{400}}{\text { concentration }}$ for } & \multirow{2}{*}{$\begin{array}{l}\text { Wave length in } \\
\text { millimicrons }\end{array}$} & \multicolumn{3}{|c|}{ Values of $\frac{A_{250}-A_{400}}{\text { concentration }}$ for } \\
\hline & $\begin{array}{l}\text { A solu- } \\
\text { tion per } \\
\text { gram }\end{array}$ & $\begin{array}{c}\mathrm{B}_{1} \text { solu- } \\
\text { tion per } \\
10 \mathrm{~g}\end{array}$ & $\begin{array}{l}\mathrm{B}_{2} \text { solu- } \\
\text { tion per } \\
10 \mathrm{~g}\end{array}$ & & $\begin{array}{l}\text { A solu- } \\
\text { tion per } \\
\text { gram }\end{array}$ & $\begin{array}{c}\mathrm{B}_{1} \text { solu- } \\
\text { tion per } \\
10 \mathrm{~g}\end{array}$ & $\begin{array}{c}\mathrm{B}_{2} \text { solu- } \\
\text { tion per } \\
10 \mathrm{~g}\end{array}$ \\
\hline $380 \ldots$ & -0.0267 & 0.0000 & -0.0008 & $560 \ldots$ & +0.0129 & -0.0006 & -0.0057 \\
\hline 390 & -.0212 & .0000 & -.0009 & $\begin{array}{l}570 \ldots \\
580 \ldots\end{array}$ & $\begin{array}{r}+.0132 \\
+.0127\end{array}$ & $\begin{array}{l}-.0009 \\
-.0012\end{array}$ & $\begin{array}{l}-.0040 \\
-.0018\end{array}$ \\
\hline & $\begin{array}{l}-.0162 \\
-.0116\end{array}$ & $\begin{array}{l}.0000 \\
.0000\end{array}$ & $\begin{array}{l}-.0010 \\
-.0011\end{array}$ & 590 & +.0110 & -.0016 & -.0013 \\
\hline 420 & -.0078 & .0000 & -.0012 & 600 & +.0084 & -.0021 & -.0010 \\
\hline 430. & -.0049 & .0000 & -.0014 & 610 & +.0057 & -.0028 & -.0008 \\
\hline $440 \ldots$ & -.0032 & .0000 & -.0015 & $\begin{array}{l}620 \ldots \\
630\end{array}$ & $\begin{array}{r}+.0026 \\
-.0007\end{array}$ & $\begin{array}{l}-.0036 \\
-.0045\end{array}$ & $\begin{array}{l}-.0007 \\
-.0006\end{array}$ \\
\hline 450 & $\begin{array}{l}-.0021 \\
-.0013\end{array}$ & $\begin{array}{l}.0000 \\
.0000\end{array}$ & $\begin{array}{l}-.0017 \\
-.0018\end{array}$ & $640 \ldots$ & -.0037 & -.0056 & -.0005 \\
\hline 470 & -.0006 & .0000 & -.0019 & 650 . & -.0066 & -.0068 & -.0004 \\
\hline 480 & .0000 & .0000 & -.0021 & 660. & -.0090 & -.0081 & -.0003 \\
\hline 490 & +.0008 & .0000 & -.0023 & 670 & -.0109 & -.0095 & -.0002 \\
\hline 500 & +.0020 & .0000 & -.0027 & $690 \ldots$ & $\begin{array}{l}-.0124 \\
-.0138\end{array}$ & $\begin{array}{l}-.0110 \\
-0125\end{array}$ & $\begin{array}{r}-.0001 \\
.0000\end{array}$ \\
\hline 510. & +.0038 & .0000 & -.0039 & & & & \\
\hline 520 - & +.0062 & .0000 & -.0053 & $700 \ldots$ & -.0148 & -.0141 & .0000 \\
\hline $530 \ldots$ & +.0087 & -.0001 & -.0062 & 710 & -.0157 & -.0158 & .0000 \\
\hline $540 \ldots$ & +.0107 & -.0002 & -.0062 & 720 & -.0164 & -.0175 & .0000 \\
\hline 550 & +.0123 & -.0004 & -.0060 & & & & \\
\hline
\end{tabular}

1 All the values of this table are uncertain in the fourth decimal place. See Section VII, 4, and Figures 22 and 23 for details of derivation.

\section{VARIATION OF PYRIDINE CONTENT IN SOLUTION A}

To study and illustrate the effect of varying the amount of pyridine used, five solutions were prepared, Nos. $62-26-\mathrm{A}$ to E, all containing $3 \mathrm{~g}$ of copper sulphate and mannite, and containing, respectively, $10,20,30,50$, and 100 cc of pyridine per liter of solution. Measurements were made in November, 1927, from 4 to 12 days after preparation of the solutions. Solution thicknesses of 10 and $100 \mathrm{~mm}$ were used. The eight $\mathrm{Hg}$ and $\mathrm{He}$ wave lengths were used, in addition to $460 \mathrm{~m} \mu, 620 \mathrm{~m} \mu$, and $720 \mathrm{~m} \mu$ in some cases.

The values obtained are illustrated in Figure 24 compared with the standard data for solution $\mathrm{A}^{\prime}$ as given in Table 4 . The effect of increasing the pyridine content is to increase the absorbancy over most of the spectral range and to shift the wave length of maximum absorbancy toward shorter wave lengths. The effect in the blue and violet is small, but may, of course, increase in the ultra-violet.

The results of this test have been further illustrated in Figure 8 (Sec. IV , 1) where the absorbancy is plotted as a function of the pyridine content at the various wave lengths. The smooth curves therein drawn pass through the standard values for $30 \mathrm{cc}$; and the effect of any variation of pyridine strength may thus be obtained at these wave lengths from this figure.

Similar results had been found by preliminary measurements made in 1926. Computations based on the later data illustrated in Figures 8 and 24 show that little if any improvement in the energy distribution of the completed filters could have been obtained with a pyridine content other than the standard concentration chosen. This is illustrated in Section VIII, 3. 


\section{BEER'S LAW}

(a) SOLUTION A

Measurable deviations from Beer's law were found for solution A. The principal measurements were made on solutions Nos. 62-13-A to $\mathrm{E}$, containing $1,2,3,4$, and $5 \mathrm{~g}$, respectively, of copper sulphate
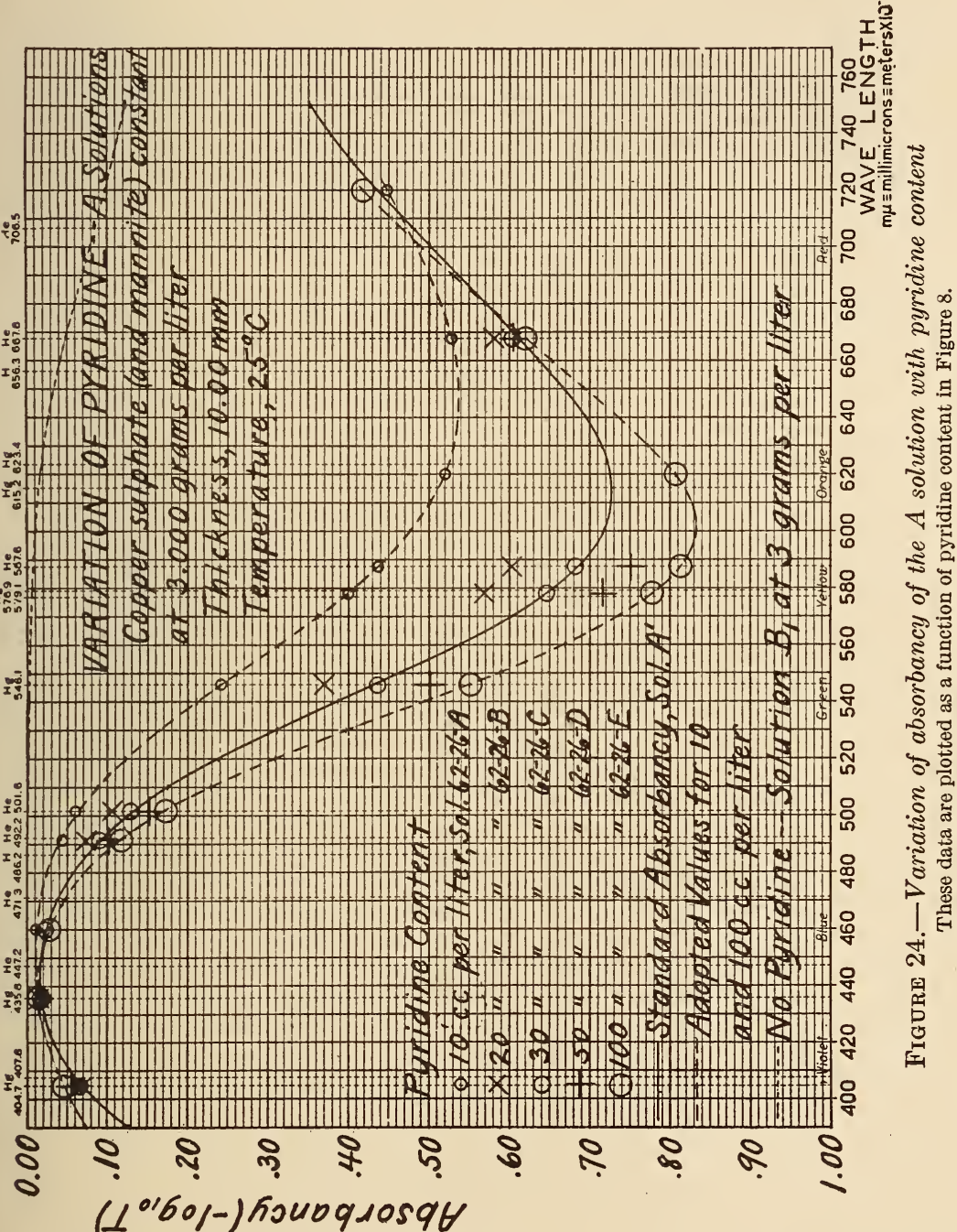

and mannite per liter of solution, each solution containing also $30 \mathrm{cc}$ of pyridine. Measurements were made nine days after preparation of the solutions, at $404.7 \mathrm{~m} \mu, 435.8 \mathrm{~m} \mu, 546.1 \mathrm{~m} \mu, 578.0 \mathrm{~m} \mu$, and $680 \mathrm{~m} \mu$ for each solution. Thicknesses of 10,20 , and $40 \mathrm{~mm}$ were used, the thickness used depending on the concentration. Reduction of the data to $10 \mathrm{~mm}$ and $3 \mathrm{~g}$ resulted in the values given in Table 17, 
columns 2 to 6 . Each value of $\mathrm{A} \frac{c_{s}}{c}$ there tabulated represents the absorbancy measured, divided by the thickness (in centimeters), and further divided by one-third of the concentration (in grams of copper sulphate and mannite per liter). They are thus proportional to the specific absorptive indices, and their variation with concentration illustrates the failure of Beer's law. Within experimental uncertainty and to an accuracy sufficient for the purpose, this change in the absorbancies of Table 17 may be taken as constant from one concentration to another at any wave length. An average change per gram is accordingly tabulated in cloumn 7 of Table 17, these values being computed by averaging the differences between the $3 \mathrm{~g}$ values of column 4 and the values of columns 3 and 5 and one-half the differences between column 4 and columns 2 and 6 .

\section{TABLE 17.-Beer's law data for solution A}

Thickness $10.00 \mathrm{~mm}$, temperature $25^{\circ} \mathrm{C}$. Other experimental data are illustrated in Figure 25. The Beer's law correction factor is defined as (see Secs. V, 3 and VII, 6):

wherein $A_{s}$ and $c_{s}$ refer to the 3-g solution.

$$
B=\frac{A\left(\frac{c_{s}}{c}\right)-A_{d}}{\left(c-c_{s}\right) A_{d}}
$$

\begin{tabular}{|c|c|c|c|c|c|c|c|}
\hline \multirow{3}{*}{ Wave length in millimicrons } & \multirow{2}{*}{\multicolumn{5}{|c|}{$\begin{array}{l}\text { Values of A }\left(\frac{c s}{c}\right) \text { for solutions Nos. } 62-13-\mathrm{A} \text { to E } \\
\text { having the following concentrations in grams of } \\
\text { copper sulphate and mannite per liter (pyridine } \\
\text { content } 30.0 \text { cc throughout) }\end{array}$}} & \multirow{3}{*}{ 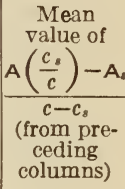 } & \multirow{3}{*}{$\frac{A\left(\frac{c_{s}}{c}\right)-A_{s}}{\left(c-c_{s}\right) A_{s}}=$} \\
\hline & & & & & & & \\
\hline & 1.000 & 2.000 & 3.000 & 4.000 & 5.000 & & \\
\hline $\begin{array}{l}404.7 \\
435.8 \\
578.0\end{array}$ & $\begin{array}{r}0.088 \\
.023 \\
.448 \\
.658 \\
.577\end{array}$ & $\begin{array}{r}0.080 \\
.022 \\
.438 \\
.652 \\
.573\end{array}$ & $\begin{array}{r}0.076 \\
.022 \\
.435 \\
.647 \\
.576\end{array}$ & $\begin{array}{l}0.068 \\
.020 \\
.427 \\
.640 \\
.568\end{array}$ & $\begin{array}{l}0.073 \\
.025 \\
.423 \\
.634 \\
.570\end{array}$ & $\begin{array}{r}-0.0049 \\
-.0002 \\
=.0059 \\
=.0060 \\
-.0021\end{array}$ & $\begin{array}{l}-0.065 \\
=.009 \\
=.014 \\
=.009 \\
-.004\end{array}$ \\
\hline
\end{tabular}

This average change per gram is seen to approximate an average change in transmittancy of about 1 per cent. For purposes of applying the Beer's law correction, it is more convenient, however, to express the change as a fractional change in the absorbancy. This is done in column 8 of Table 17 , these values resulting from dividing the values of column 7 by those of column 4 . They are plotted in Figure 25. This fractional change in absorbancy per gram difference from the standard has been defined as $B($ Sec. V, 3 ) in the equations

and

$$
\mathrm{A}=\frac{\mathrm{A}_{s}}{c_{s}} c\left[1+B(c-c)_{s}\right]
$$

$$
B=\frac{\mathrm{A}\left(\frac{c_{s}}{c}\right)-\mathrm{A}_{s}}{\left(c-c_{s}\right) \mathbf{A}_{s}}
$$

These measurements were made on unfiltered solutions, the usual condition unless otherwise noted. Similar measurements on a series of filtered solutions gave a similar set of values of $B$, these being 
also shown in Figure 25. Measurements were also made with 2 and $4 \mathrm{~g}$ unfiltered solutions, with mannite constant at $3 \mathrm{~g}$, and likewise with mannite constant at $10 \mathrm{~g}$. These results are all plotted in Figure 25. Only at $404.7 \mathrm{~m} \mu$ was it felt that the value of $B$ was certainly different from -0.010 . Accordingly, this value was adopted for the wave-length range from $450 \mathrm{~m} \mu$ to $720 \mathrm{~m} \mu$.

In order to confirm the results obtained at $404.7 \mathrm{~m} \mu$ and to extend the correction into the ultra-violet, photographic measurements were made. Six solutions were prepared, Nos. $65-8-\left(\frac{1}{2}\right) \mathrm{A}$ and $65-8-\mathrm{A}$ to $\mathrm{E}$, containing, respectively, $1 / 2 \mathrm{~g}$ and 1 to $5 \mathrm{~g}$ of copper sulphate and mannite per liter of solution. Each solution contained $30 \mathrm{cc}$ of pyridine per liter. Measurements were made three weeks after preparation of the solutions. The results were derived in a manner similar to the values of Table 17 and gave the values of $B$ shown in Figure 25. In the same figure are shown also the adopted values of $B$-from $720 \mathrm{~m} \mu$ to $400 \mathrm{~m} \mu$ on the basis of the previous visual measurements described above, and from $390 \mathrm{~m} \mu$ to $350 \mathrm{~m} \mu$ on the basis of the photographic measurements. These adopted values are those given in Table 4. Measurements of the effect were again made visually at $404.7 \mathrm{~m} \mu, 435.8 \mathrm{~m} \mu$, and $491.6 \mathrm{~m} \mu$ with the six solutions used in the photographic measurements, four weeks after preparation. These values are also given in Figure 25.

It might reasonably be questioned, after examination of Figure 25, whether the adopted values of the Beer's law correction factor represent the experimental data as satisfactorily as some alternative curve which might be plotted. As a matter of fact, if the true Beer's law correction factors were of primary importance, more data would have to be taken to determine them with high accuracy. Here, as elsewhere throughout the investigation, the influence of the data on the complete filters was effective in determining the extent of the data.

For example, could any other set of Beer's law correction factors be adopted on the basis of the experimental data of Figure 25 which would change the computed spectral transmission of any of the filters (and, therefore, the resulting energy distribution) by as much as 1 per cent? That there could be no such set of values may be shown as follows:

If $\Delta \mathrm{A}$ represent the error in $\mathrm{A}$ caused by an error $\Delta B$ in $B$, then from the first equation above, we have

$$
\Delta \mathrm{A}=\Delta B\left[\frac{c\left(c-c_{s}\right) \mathrm{A}_{s}}{c_{s}}\right]
$$

For any given values of $\Delta B, c_{s}$, and $\mathrm{A}_{s}$, it is obvious that $\Delta \mathbf{A}=0$ when $c=0$ or when $c=c_{s}$. For values of $c$ greater than $c_{s}, \Delta \mathrm{A}$ continuously increases as $c$ increases. By differentiating $\Delta \mathrm{A}$ with respect to $c$ and equating to zero, we obtain $c=c_{s} / 2$, so that for values of $c$ between 0 and $c_{s}, \Delta \mathrm{A}$ has a maximum absolute value when $c=c_{s} / 2$, or in the present case when $c=1.5 \mathrm{~g}$ of copper sulphate.

We wish, however, to know what values of $\Delta B$ will cause $\Delta \mathbf{A}$ to equal 0.00434 , thereby producing a 1 per cent error in the transmittancy. The equation connecting $\Delta \mathrm{A}$ and $\Delta B$ may be rewritten

$$
\Delta B=\frac{\frac{c_{s}}{c} \Delta \mathrm{A}}{\left(c-c_{s}\right) \mathrm{A}}
$$


as is shown in Figure 25. It follows, for any given values of $\triangle \mathbf{A}, c_{s}$, and $\mathrm{A}_{s}$, that $\Delta B$ is infinite when $c=c_{s}$ or when $c=0$, that for values of $c$ greater than $c_{s}, \Delta B$ continuously decreases as $c$ increases, and that for $c$ less than $c_{s}, \Delta B$ has a minimum absolute value at $c=c_{s} / 2$.

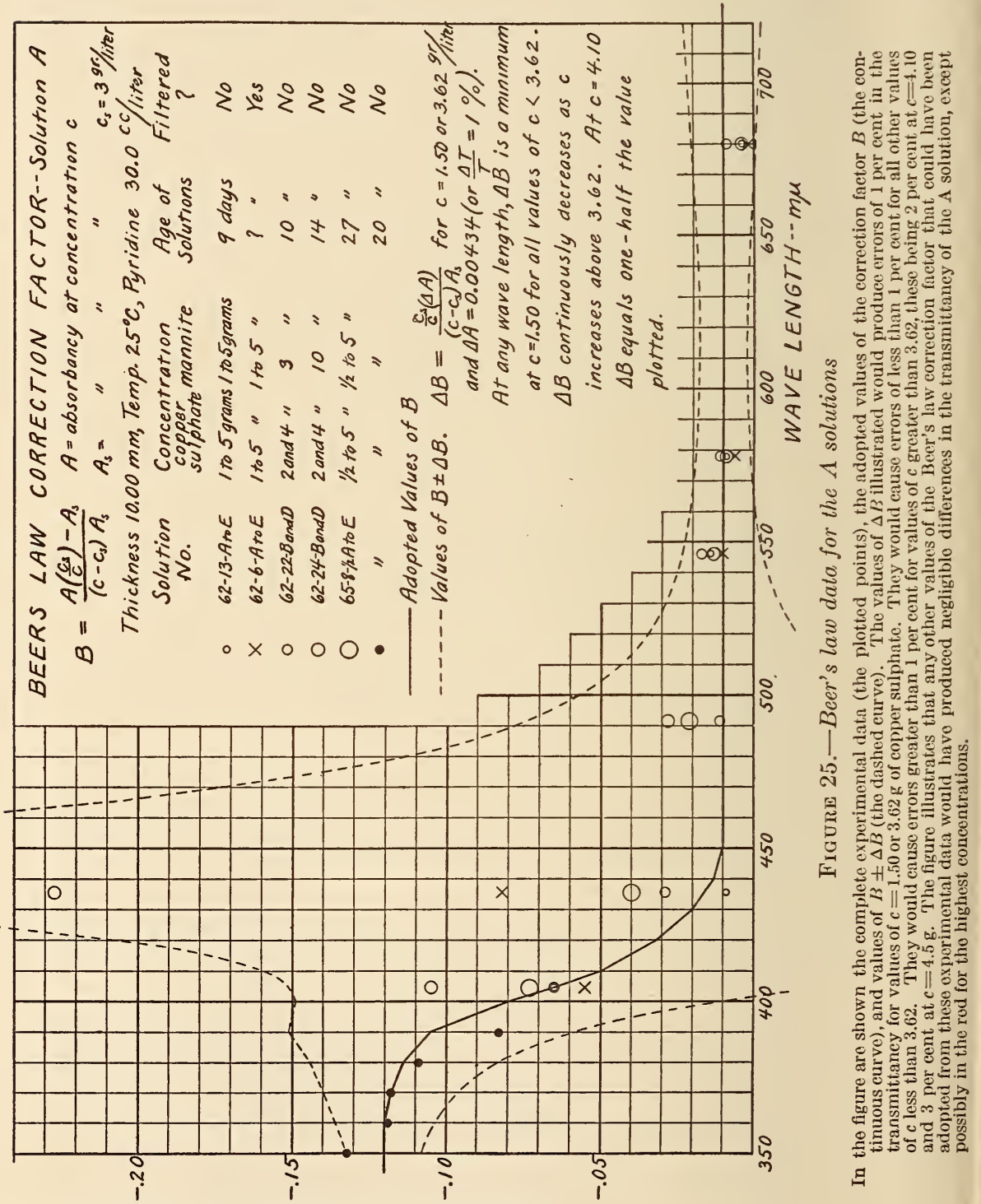

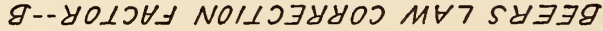

Values of $\Delta B$ have been computed for values of $\Delta \mathrm{A}=0.00434$, for values of $\mathbf{A}_{s}$ as given in Table 4, with $c_{s}=3$, and with a value of $c=1.50$ (or 3.62 , which gives practically the same absolute values of $\Delta B$ ). These values of $\Delta B$, which are required to produce a 1 
per cent error in the transmittancy, are illustrated in Figure 25 where values of $B \pm \Delta B$ are plotted as a function of wave length.

It will be noted that these dashed curves in practically all cases lie much beyond the range of the experimental data, and it has just been shown that for any values of $c$ less than 3.62 , other than 1.50, the deviations would be even greater, becoming infinite at $c=0$ and 3 . For values of $c$ greater than 3.62 the values of $\Delta B$ which will cause a value of $\Delta \mathbf{A}=0.00434$ decrease, becoming one-half the values illustrated at $c=4.10$, and one-third the values at $c=4.50$, which is a greater concentration than used in any of the filters. Even for this extreme case, any curve which might reasonably be put through the plotted data of Figure 25 would still be within the 1 per cent limits, except possibly above $600 \mathrm{~m} \mu$.

Values of $\Delta B$ computed as indicated above from the equation given in Figure 25, with $c, c_{s}$, and $\Delta \mathbf{A}$ constant, are, of course, inversely proportional to the standard absorbancy $\mathrm{A}_{s}$, which explains the general shape of the $B \pm \Delta B$ curves. The irregularity near $400 \mathrm{~m} \mu$ would be eliminated by adopting slightly different values of $B$ in this region.

(b) SOLUTION B

No failure of Beer's law was detected for the components of the B solution. Measurements were made on copper sulphate, cobalt sulphate, and cobalt ammonium sulphate, as follows: Five copper sulphate solutions were prepared, Nos. 62-7-A to E, filtered, containing, respectively, 5, 10, 20,30, and $40 \mathrm{~g}$ of copper sulphate per liter of solution. Each solution contained $10 \mathrm{cc}$ of sulphuric acid. Thicknesses of 40 and $100 \mathrm{~mm}$ were used. Measurements were made at $435.8 \mathrm{~m} \mu, 546.1 \mathrm{~m} \mu, 578.0 \mathrm{~m} \mu$, and $640 \mathrm{~m} \mu$. The values of absorbancy for each solution were then computed to $10 \mathrm{~mm}$ thickness and $20 \mathrm{~g}$ of copper sulphate. When this was done the maximum total variation for any of the five solutions at any of the four wave lengths was 0.004 , with no indication of any consistent variation with concentration.

In a similar manner five solutions of cobalt sulphate were prepared, Nos. $62-8-\mathrm{A}$ to E, filtered, containing, respectively, 2.5, 5, 10, 15, and $20 \mathrm{~g}$ of cobalt sulphate per liter of solution. Each solution contained $10 \mathrm{cc}$ of sulphuric acid. Thicknesses of 40 and $100 \mathrm{~mm}$ were used. Measurements were made at $435.8 \mathrm{~m} \mu, 491.6 \mathrm{~m} \mu, 546.1 \mathrm{~m} \mu$, and $578 \mathrm{~m} \mu$. Upon reduction of the absorbancies to $10 \mathrm{~mm}$ and $10 \mathrm{~g}$, the maximum total variation for the five solutions at any of the four wave lengths was but 0.002 .

Three solutions of cobalt ammonium sulphate were measured, Nos. 65-1-A, C, and F, unfiltered, containing, respectively, 4.827, 14.481 , and $28.962 \mathrm{~g}$ of cobalt ammonium sulphate per liter of solution. Each solution contained $10 \mathrm{cc}$ of sulphuric acid. Thicknesses of 40 and $100 \mathrm{~mm}$ were used. Measurements were made at $435.8 \mathrm{~m} \mu$, $491.6 \mathrm{~m} \mu, 501.6 \mathrm{~m} \mu, 546.1 \mathrm{~m} \mu$, and $578.0 \mathrm{~m} \mu$. Upon reduction of the absorbancies to $10 \mathrm{~mm}$ and $14.481 \mathrm{~g}$, the maximum total variation for any solution at any of the five wave lengths was 0.0014 . They are undoubtedly merely a result of experimental uncertainty. Furthermore, both copper sulphate and cobalt sulphate in aqueous solution have previously been found to obey Beer's law over a larger range of concentrations (51, p. $31 ; 52$, p. 775$)$. 
There still might remain the question of whether the mixture of copper sulphate and cobalt ammonium sulphate would obey Beer's law, as mixed in the present filters to form solution B. This was not tested directly, but two of the experimental checks elsewhere described show that any failure is quite negligible. These checks are:

1. The measurements on the completed $4,000^{\circ} \mathrm{K}$.-to-mean-sun filter. (Sec. VIII, 1.) The concentrations of both components of solution B are in this case near their lower limits. The very good check obtained between the computed and directly measured values leaves no reasonable question of the practical obedience to Beer's law at the low concentrations.

2. The test of reproducibility (Sec. VII, 8) on solution B of the $2,360^{\circ}$ K.-to-mean-sun filter. In this case the concentrations of both components are near their higher limits. The values thus obtained, compared with the standard computed values for the $2,360^{\circ}$ $\mathrm{K}$. B solutions, show that there can be no important deviation of Beer's law at the higher concentrations.

\section{RELIABILITY OF THE SPECTROPHOTOMETRIC MEASUREMENTS}

The data given in the present section are intended primarily to illustrate the reliability of the adopted absorbancy values given in Tables 4, 5, and 6 as pertaining to solutions prepared from the chemicals described in Section IV, 2. They do not, except where clearly indicated, illustrate the reproducibility obtainable from different lots oi chemicals, which subject is considered in Section VII, 8, following.

\section{(a) AT THE Hg AND He WAVE LENGTHS}

The most fundamental and reliable spectrophotometric data on the solutions are the absorbancy values given for the standard solutions, Nos. $\mathrm{A}^{\prime}, \mathrm{B}_{1}{ }^{\prime}, \mathrm{B}_{2}{ }^{\prime}$, and $\mathrm{B}^{\prime}$, at the eight reference $\mathrm{Hg}$ and He wave lengths, viz, $404.7 \mathrm{~m} \mu, 435.8 \mathrm{~m} \mu, 491.6 \mathrm{~m} \mu, 501.6 \mathrm{~m} \mu, 546.1 \mathrm{~m} \mu, 578.0 \mathrm{~m} \mu, 587.6 \mathrm{~m} \mu$, and $667.8 \mathrm{~m} \mu$. The use of these light sources eliminates the possibility of errors arising from incorrect wave-length calibrations and the use of finite slit widths with a continuous spectrum source. The data with the homogeneous light sources at these eight wave lengths are, in general, quite extensive, including usually measurements on several different solutions and at various thicknesses and intervals after preparation.

A complete summary of the experimental values obtained on the standard solutions is given in Tables 18 to 21 . As a function of wave length is tabulated first the adopted absorbancy values and then for the various solutions, as indicated, values of $A-A_{s}$ where $A_{s}$ refers to the adopted absorbancy values and $A$ the experimental values. Algebraic means are also tabulated as may be noted. In compiling Tables 18 to 21 , no data which were taken at any time during the investigation have been omitted, whether obtained before or after the standard values were adopted, except that in Table 18 only those data are shown which were obtained on solutions prepared from commercial pyridine. Where values are tabulated representative of two or more determinations they are an arithmetical mean, unweighted, all values being reduced to $10 \mathrm{~mm}$ thickness before being averaged. 
The data for solutions $\mathrm{B}_{1}{ }^{\prime}$ and $\mathrm{B}_{2}{ }^{\prime}$ show, in general, higher precision and better agreement with the adopted values than do the data for solution $\mathrm{A}^{\prime}$, particularly if the data for the first four days on solution $\mathrm{B}_{1}^{\prime}$ be excluded, as they were when the standard values were adopted. This difference between the $\mathrm{A}^{\prime}$ solution and the components of the $\mathrm{B}^{\prime}$ solution results, at least principally, from two causes:

1. In the concentrations as used and for these eight wave lengths the absorbancies for solution $A^{\prime}$ reach a higher value than for either $\mathrm{B}_{1}^{\prime}$ or $\mathrm{B}_{2}^{\prime}$. Above $546.1 \mathrm{~m} \mu$, thicknesses of 10 and $20 \mathrm{~mm}$ were the only ones used for solution $\mathrm{A}^{\prime}$, whereas for solution $\mathrm{B}_{1}{ }^{\prime}$ and $\mathrm{B}_{2}{ }^{\prime}$, thicknesses from 10 to $100 \mathrm{~mm}$ could be used, except only at $667.8 \mathrm{~m} \mu$ with $\mathrm{B}_{1}{ }^{\prime}$. Increased thickness makes for more precise determination when the values are reduced to a $10 \mathrm{~mm}$ basis.

2. Solutions $\mathrm{B}_{1}{ }^{\prime}$ and $\mathrm{B}_{2}{ }^{\prime}$ show no important change with time as does $\mathrm{A}^{\prime}$. (Sec. VII, 3.)

The absorbancies for solution $\mathrm{B}^{\prime}$, the sum of those adopted for $\mathrm{B}_{1}{ }^{\prime}$ and $\mathrm{B}_{2}{ }^{\prime}$, should, therefore, have a reliability fully the equal of, probably better than, solution $A^{\prime}$. It is rather difficult to summarize the data further than is done in Tables 18 to 21. It seems, however, correct to say-considering the respective algebraic means of the deviations of the complete data from the adopted data, for a time interval from a week to perhaps two months after preparation, for the chemicals as analyzed and used, and possibly excepting the data at $404.7 \mathrm{~m} \mu$ and $667.8 \mathrm{~m} \mu$-that the adopted absorbancies at these eight wave lengths for solutions $\mathrm{A}^{\prime}, \mathrm{B}_{1}{ }^{\prime}, \mathrm{B}_{2}{ }^{\prime}$, and $\mathrm{B}^{\prime}$ in $10 \mathrm{~mm}$ thicknesses are accurate to 0.001 or better, or one-quarter per cent of the transmittancy. (The accuracy of the photometric scale of the Koenig-Martens spectrophotometer is, of course, involved in such a conclusion. As shown in a recent paper by McNicholas (45), by tests with accurately calibrated rotating sectors, part of which tests were carried out during the period of the present measurements, no error in the photometric scale of this particular instrument has ever been found, provided that measurements are made under such experimental conditions that the angle of photometric match is not close to the $0^{\circ}$ or $90^{\circ}$ points. The accuracy of the present data is further certified by the fact that the adopted data are in all cases based on measurements with two or more thicknesses of solution.) 
TABLE 19.-Experimental data on solution $B^{\prime}$, standard acidified aqueous solution of copper sulphate, at the eight Hg and He wave lengths

[Thickness $10.00 \mathrm{~mm}$., temperature, $\left.25^{\circ} \mathrm{C}.\right]$

\begin{tabular}{|c|c|c|c|c|c|c|c|c|c|c|}
\hline \multirow{9}{*}{$\begin{array}{l}\text { Wave length } \\
\text { in millimi- } \\
\text { crons }\end{array}$} & \multirow{9}{*}{$\begin{array}{c}\text { Stand- } \\
\text { ard } \\
\text { absorb- } \\
\text { ancy A- }\end{array}$} & \multicolumn{9}{|c|}{ Absorbancy as measured, A, minus adopted standard absorbancy, $\mathrm{A}_{s}{ }^{1}$} \\
\hline & & \multicolumn{7}{|c|}{ Solution number } & \multirow{4}{*}{\multicolumn{2}{|c|}{$\begin{array}{r}\text { Algebraic } \\
\text { means } 3\end{array}$}} \\
\hline & & $62-18^{2}$ & $62-18$ & $62-1$ & $62-1$ & $62-5^{2}$ & $62-7-\mathrm{C}$ & $62-7-\mathrm{C}$ & & \\
\hline & & \multicolumn{7}{|c|}{ Determinations } & & \\
\hline & & 3 & $2,3,4$ & 1 & 1 & 1 & 1 & 1 & & \\
\hline & & & & Days & after prep & aration & & & \multirow{4}{*}{ All data } & \multirow{4}{*}{$\begin{array}{l}\text { Ex- } \\
\text { clud- } \\
\text { ing } \\
\text { values } \\
\text { for }<5 \\
\text { days }\end{array}$} \\
\hline & & $0,1,4$ & 12,14 & 4 & 27 & 2 & 7 & 35 & & \\
\hline & & \multicolumn{7}{|c|}{ Solution filtered? } & & \\
\hline & & No & No & Yes & Yes & No & Yes & Yes & & \\
\hline $\begin{array}{l}\text { Hg } 404.7 \\
\text { Hg } 435.8 \\
\text { Hg } 491.6 \\
\text { He } 501.6 \\
\text { Hg } 546.1 \\
\text { Hg } 578.0 \\
\text { He } 587.6 \ldots \\
\text { He } 667.8 \\
\end{array}$ & $\begin{array}{l}0.0021 \\
.0013 \\
.0019 \\
.0028 \\
.0135 \\
.0368 \\
.0487 \\
.319\end{array}$ & $\begin{array}{l}+0.0031 \\
+.0030 \\
+.0030 \\
+.0023 \\
+.0021 \\
+.0019 \\
+.0018 \\
+.001\end{array}$ & $\begin{array}{r}-0.0004 \\
-.0001 \\
+.0003 \\
+.0004 \\
-.0009 \\
-.0011 \\
+.0002 \\
.000\end{array}$ & \begin{tabular}{r}
+0.0012 \\
+.0008 \\
- \\
\hdashline .0003 \\
+.0004
\end{tabular} & $\begin{array}{r}+0.0005 \\
+.0002 \\
-.0001 \\
.0000\end{array}$ & $\begin{array}{r}+0.0031 \\
+.0030 \\
+.0030 \\
+.0030\end{array}$ & $\begin{array}{r}0.0000 \\
+.0001 \\
+.0002 \\
\end{array}$ & $\begin{array}{r}+0.0001 \\
.0000 \\
-.0005 \\
-.0006 \\
-.0005 \\
-.0002 \\
-.0013 \\
-.001\end{array}$ & $\begin{array}{l}+0.0015 \\
+.0013 \\
+.0015 \\
+.0012 \\
+.0005 \\
+.0004 \\
+.0006 \\
+.0003\end{array}$ & $\begin{array}{r}0.0000 \\
.0000 \\
.0000 \\
+.0001 \\
-.0006 \\
-.0006 \\
-.0001 \\
-.0002\end{array}$ \\
\hline
\end{tabular}

${ }_{1} \mathrm{~A}-\mathrm{A}_{s}=0.00434$ is equivalent to a 1 per cent difference in transmittancy.

2 These data illustrate turbidity effect of first few days with unfiltered solutions.

3 Weighted according to the number of determinations.

TABLE 20.-Experimental data on solution $B_{2}{ }^{\prime}$ standard acidified aqueous solution of cobalt sulphate or cobalt ammonium sulphate, at the eight $\mathrm{Hg}$ and $\mathrm{He}$ wave lengths

[Thickness $10.00 \mathrm{~mm}$, temperature $25^{\circ} \mathrm{C}$.]

\begin{tabular}{|c|c|c|c|c|c|c|c|c|c|}
\hline \multirow{11}{*}{$\begin{array}{l}\text { Wave length } \\
\text { in } \\
\text { millimicrons }\end{array}$} & \multirow{11}{*}{$\begin{array}{c}\text { Stand- } \\
\text { ard ab- } \\
\text { sorb- } \\
\text { ancy } \\
\mathrm{A}_{s}\end{array}$} & \multicolumn{8}{|c|}{ Absorbancy as measured, A, minus adopted standard absorbancy, A,1 } \\
\hline & & \multicolumn{7}{|c|}{ Material } & \multirow{10}{*}{$\begin{array}{l}\text { Alge- } \\
\text { braic } \\
\text { mean, } \\
\text { all } \\
\text { data }\end{array}$} \\
\hline & & \multicolumn{5}{|c|}{ Cobalt sulphate } & \multicolumn{2}{|c|}{$\begin{array}{l}\text { Cobalt ammonium } \\
\text { sulphate }\end{array}$} & \\
\hline & & \multicolumn{7}{|c|}{ Solution number } & \\
\hline & & $62-17$ & $62-17$ & $61-10$ & $62-8-\mathrm{C}$ & $62-8-\mathrm{C}$ & $62-20$ & $65-1-\mathrm{C}$ & \\
\hline & & \multicolumn{7}{|c|}{ Determinations } & \\
\hline & & 3 & 2 & 3 & 1 & 1 & 1 & 1 & \\
\hline & & \multicolumn{7}{|c|}{ Days after preparation } & \\
\hline & & $0,1,4$ & 13,15 & $(?)$ & 3 & 38 & 4 & 16 & \\
\hline & & \multicolumn{7}{|c|}{ Filtered? } & \\
\hline & & No & No & No & Yes & Yes & No & No & \\
\hline $\begin{array}{l}\text { Hg } 404.7 \\
\text { Hg } 435.8 \\
\text { Hg } 491.6 \\
\text { He } 501.6 \\
\text { Hg } 546.1 \\
\text { Hg } 578.0 \\
\text { He } 587.6 \\
\text { He } 667.8 \\
\end{array}$ & $\begin{array}{r}0.0144 \\
.0437 \\
.1497 \\
.1661 \\
.0901 \\
.0219 \\
.0167 \\
.0089\end{array}$ & $\begin{array}{r}+0.0006 \\
+.0007 \\
+.0001 \\
+.0009 \\
+.0010 \\
+.0005 \\
+.0004 \\
+.0005\end{array}$ & $\begin{array}{r}+0.0004 \\
+.0002 \\
+.0006 \\
+.0002 \\
-.0003 \\
-.0001 \\
+.0001 \\
.0000\end{array}$ & $\begin{array}{r}+0.0003 \\
+.0010 \\
+.0019 \\
+.0005\end{array}$ & $\begin{array}{r}-0.0004 \\
-.0007 \\
-.0010 \\
-.0004\end{array}$ & $\begin{array}{r}+0.0034 \\
+.0023 \\
+.0001 \\
+.0025 \\
+.0013 \\
+.0013 \\
+.0023 \\
+.0021\end{array}$ & $\begin{array}{r}+0.0022 \\
+.0017 \\
+.0008 \\
+.0008 \\
+.0002 \\
+.0007 \\
+.0007 \\
+.0008\end{array}$ & $\begin{array}{r}0.0000 \\
+.0015 \\
+.0001 \\
+.0007 \\
-.0001 \\
\end{array}$ & $\begin{array}{l}+0.0009 \\
+.0008 \\
+.0003 \\
+.0006 \\
+.0008 \\
+.0004 \\
+.0006 \\
+.0006\end{array}$ \\
\hline
\end{tabular}

${ }^{1} \mathrm{~A}-\mathrm{A}_{\mathrm{B}}=0.00434$ is equivalent to a 1 per cent difference in transmittancy.

2 Weighted according to the number of determinations. 
TABLE 21.-Experimental data on solution $B^{\prime}$, standard acidified aqueous solution of copper sulphate and cobalt ammonium sulphate, unfiltered, at the eight $\mathrm{Hg}$ and He wave lengths

[Thickness $10.00 \mathrm{~mm}$, temperature $25^{\circ} \mathrm{C}$.]

\begin{tabular}{|c|c|c|c|c|c|}
\hline \multirow{7}{*}{ Wave length in millimicrons } & \multicolumn{3}{|c|}{ Standard absorbancy $A_{\theta}$} & \multirow{2}{*}{\multicolumn{2}{|c|}{$\begin{array}{l}\text { A bsorbancy as meas } \\
\text { ured, A, m in us } \\
\text { adopted standard } \\
\text { absorbancy, } A_{e}^{1}\end{array}$}} \\
\hline & \multirow{6}{*}{$\begin{array}{c}\text { For } \\
\text { solution } \\
\mathbf{B}_{1}^{\prime}\end{array}$} & \multirow{6}{*}{$\begin{array}{c}\text { For } \\
\text { solution } \\
\mathbf{B}_{2}^{\prime}\end{array}$} & \multirow{6}{*}{$\begin{array}{c}\text { For } \\
\text { solution } \\
B^{\prime}= \\
B_{1}^{\prime}+B_{2}^{\prime}\end{array}$} & & \\
\hline & & & & $65-2$ & $65-2$ \\
\hline & & & & \multicolumn{2}{|c|}{ Determinations } \\
\hline & & & & 3,4 & 3,4 \\
\hline & & & & \multicolumn{2}{|c|}{$\begin{array}{l}\text { Days after prepara- } \\
\text { tion }\end{array}$} \\
\hline & & & & 8,9 & 300,301 \\
\hline $\begin{array}{l}\text { Hg } 404.7 \\
\text { Hg } 435.8 \\
\text { Hg } 491.6 \\
\text { He } 501.6 \\
\text { Hg } 546.1 \\
\text { Hg } 578.0 \\
\text { He } 587.6 \\
\text { He } 667.8\end{array}$ & $\begin{array}{l}0.0021 \\
.0013 \\
.0019 \\
.0028 \\
.0135 \\
.0368 \\
.0487 \\
.319\end{array}$ & $\begin{array}{l}0.0144 \\
.0437 \\
.1497 \\
.1661 \\
.0901 \\
.0219 \\
.0167 \\
.0089\end{array}$ & $\begin{array}{l}0.0165 \\
.0450 \\
.1516 \\
.1689 \\
.1036 \\
.0587 \\
.0654 \\
.328\end{array}$ & $\begin{array}{r}-0.0010 \\
-.0010 \\
+.0012 \\
-.0007 \\
+.0010 \\
-.0007 \\
-.0008 \\
+.001\end{array}$ & $\begin{array}{r}-0.0038 \\
-.0028 \\
+.0011 \\
+.0005 \\
+.0001 \\
-.0009 \\
-.0022 \\
.000\end{array}$ \\
\hline
\end{tabular}

${ }^{1} \mathrm{~A}-\mathrm{A}_{\mathrm{B}}=0.00434$ is equivalent to a 1 per cent difference in transmittancy.

(b) FROM $350 \mathrm{~m} \mu$ TO $720 \mathrm{~m} \mu$

The discussion in Section VII, 1 and 2, regarding the methods of measurement and the extent of the data, should be recalled in this connection. It will be remembered that the data were in all cases adjusted so that the adopted values at the eight $\mathrm{Hg}$ and $\mathrm{He}$ wave lengths fall precisely upon a smooth curve drawn through the values adopted at every $10 \mathrm{~m} \mu$.

In the neighborhood of these eight reference wave lengths, therefore, the accuracy of the data at every $10 \mathrm{~m} \mu$ should be practically equal to that for these eight wave lengths. It may well be true, however, at some of the intermediate wave lengths, particularly where the intervals are the largest, that the reliability of the data is slightly decreased. It is estimated that the accuracy of the standard absorbancies in these cases should hold to 0.002 or better, or to one-half of 1 per cent of the transmittancies. Outside of the range from $404.7 \mathrm{~m} \mu$ to $667.8 \mathrm{~m} \mu$, the uncertainty may become greater.

\section{SPECTROPHOTOMETRIC REPRODUCIBILITY OF THE CHEMICALS}

The spectrophotometric accuracy of the data obtained with the chemicals as analyzed and used in this investigation is further discussed in Section VIII, 1, where spectrophotometric data are given for various completed filters. A question of equal importance is whether or not the data would be duplicated when materials are 
obtained from various sources, with or without careful analysis. This has been investigated with the cooperation of Messrs. Jones and Richardson, of the research laboratory of the Eastman Kodak Co., in connection with special studies of the $2,360^{\circ} \mathrm{K}$-to-mean-sun filter recommended as a standard for photographic sensitometry in a resolution adopted in 1928 by the Seventh International Congress of Photography. (Sec. VI, 1.)

Three sets of solutions were prepared at the Eastman Kodak Co. and submitted to the bureau for spectrophotometric measurement. The materials were obtained from the sources listed in Table 25, and will be considered more in detail later in the section. The first two sets consisted of five $\mathrm{A}$ and five $\mathrm{B}$ solutions, numbered $1 \mathrm{~A}$ to $5 \mathrm{~A}$ and $1 \mathrm{~B}$ to $5 \mathrm{~B}$, having compositions as specified in chart 2 for the $2,360^{\circ}$ K.-to-mean-sun filter. So far as this first set of A solutions was concerned, the purposes of the test were partially defeated because the authors neglected to inform those preparing the solutions that they should not be filtered. Solutions Nos. $1 \mathrm{~A}$ to $5 \mathrm{~A}$ and $1 \mathrm{~B}$ to $5 \mathrm{~B}$ were filtered. As shown in Section VII, 7, it is a matter of practical indifference whether the B solutions are filtered or not; but this is not the case with the A solutions, so that the spectrophotometric measurements with the first set of A solutions may show among other things the effect of filtering the solutions.

Later on another set of A solutions, Nos. 1A-2 to 5A-2 was prepared at the Eastman Kodak Co. These A-2 solutions were not filtered; they were prepared from the same lots of copper sulphate as the previous A solutions; they were prepared from new lots of pyridine obtained from the same sources as before; the pyridine was carefully tested for strength, and the solutions prepared using the equivalent of 30.0 cc per liter of 98.4 per cent strength pyridine in each solution.

The spectrophotometric measurements on all three sets of solutions were made at the bureau. Values of absorbancy were measured at certain selected wave lengths, at $25^{\circ} \mathrm{C}$., and at two or more thicknesses (except with the B solutions, where measurements were made at but one thickness in the regions of minimum absorbancy).

The results are shown in Tables 22, 23, and 24, wherein are given: (1) Standard values of absorbancy, that is, those obtained by computation using the standard spectrophotometric data of Tables 4 to 6 in the same manner as was done for the A and B components of all of the filters, (2) values of absorbancy obtained experimentally with the respective solutions, (3) differences between the standard and these observed absorbancies, (4) the percentage differences between the standard and observed transmittancies, and (5) the percentage ratios of the observed to the standard absorbancies, in those cases where the absorbancies are great enough to make these ratios of possible significance from an analytical standpoint. 
TABLE 22.-Test of spectrophotometric reproducibility of chemicals for solution A, filtered, $2,360^{\circ} \mathrm{K}$. to mean sun; thickness, $10.00 \mathrm{~mm}$, temperature, $25^{\circ} \mathrm{C}$., age, 1 month. Pyriaine not tested before preparation of solutions

[Solutions prepared at Eastman Kodak Co.; spectrophotometric measurements at National Bureau of Standards]

\begin{tabular}{|c|c|c|c|c|c|c|c|}
\hline \multirow{3}{*}{$\begin{array}{l}\text { Wave length in } \\
\text { millimicrons }\end{array}$} & \multicolumn{7}{|c|}{ Spectrophotometric data 1} \\
\hline & \multirow{2}{*}{$\begin{array}{l}\text { Standard } \\
\text { values }\end{array}$} & \multicolumn{5}{|c|}{ Experimental values for solutions Nos. } & \multirow{2}{*}{$\begin{array}{l}\text { Mean } 1 \mathrm{~A} \\
\text { to } 5 \mathrm{~A}\end{array}$} \\
\hline & & $1 \mathrm{~A}$ & $2 \mathrm{~A}$ & $3 \mathrm{~A}$ & $4 \mathrm{~A}$ & $5 \mathrm{~A}$ & \\
\hline Hg $404.7 \ldots$ & 0.0802 & $\begin{array}{l}0.0836 \\
+.0034 \\
+.8\end{array}$ & $\begin{array}{l}0.0786 \\
-.0016 \\
-.4\end{array}$ & $\begin{array}{l}0.0825 \\
+.0023 \\
+.5\end{array}$ & $\begin{array}{l}0.0760 \\
-.0042 \\
-1.0\end{array}$ & $\begin{aligned} & 0.0956 \\
+ & .0154 \\
+ & 3.5\end{aligned}$ & +0.7 \\
\hline Hg 435.8 & .0220 & $\begin{array}{l}.0256 \\
+.0036 \\
+.8\end{array}$ & $\begin{array}{l}.0218 \\
-.0002 \\
.0\end{array}$ & $\begin{array}{l}.0218 \\
-.0002 \\
.0\end{array}$ & $\begin{aligned} & .0193 \\
-.0027 & -.6\end{aligned}$ & $\begin{array}{r}.0300 \\
+.0080 \\
+1.8\end{array}$ & +.4 \\
\hline Hg 491.6.... & .1117 & $\begin{aligned} & .1132 \\
+ & .0015 \\
+ & .3\end{aligned}$ & $\begin{array}{l}.0990 \\
-.0127 \\
-2.9\end{array}$ & $\begin{array}{l}.1110 \\
-.0007 \\
-.2\end{array}$ & $\begin{array}{r}.1038 \\
-.0079 \\
-1.8\end{array}$ & $\begin{array}{l}.1026 \\
-.0091 \\
-2.1\end{array}$ & -1.3 \\
\hline He 501.6 ....... & .1607 & $\begin{array}{l}.1576 \\
-.0031 \\
-.7\end{array}$ & $\begin{aligned} & .1504 \\
&-.0103 \\
&-2.4\end{aligned}$ & $\begin{aligned} & .1598 \\
-.0009 & -.2\end{aligned}$ & $\begin{aligned} & .1541 \\
&-.0066 \\
&-1.5\end{aligned}$ & $\begin{array}{r}.1561 \\
-.0046 \\
-1.1\end{array}$ & -1.2 \\
\hline Hg 546.1 .... & .5325 & $\begin{aligned} .5182 \\
-.0143 \\
-3.3 \\
97.3\end{aligned}$ & $\begin{aligned} .5109 \\
-.0216 \\
-5.0 \\
95.9\end{aligned}$ & $\begin{array}{r}.5254 \\
-.0071 \\
-1.6 \\
98.7\end{array}$ & $\begin{aligned} & .5236 \\
&-.0089 \\
&-2.0 \\
& 98.3\end{aligned}$ & $\begin{array}{r}.5192 \\
-.0132 \\
-3.0 \\
97.5\end{array}$ & -3 \\
\hline Hg 578.0 & .7926 & $\begin{aligned} .7784 \\
-.0142 \\
-3.3 \\
98.2\end{aligned}$ & $\begin{aligned} .7569 \\
-.0357 \\
-8.2 \\
95.5\end{aligned}$ & $\begin{aligned} .7827 \\
-.0099 \\
-2.3 \\
98.8\end{aligned}$ & $\begin{aligned} .7844 \\
-.0082 \\
-1.9 \\
99.0\end{aligned}$ & $\begin{aligned} .7690 \\
-.0236 \\
-5.4 \\
97.0\end{aligned}$ & -4.2 \\
\hline He 587.6.... & .8405 & $\begin{aligned} .8292 \\
-.0113 \\
-2.6 \\
98.7\end{aligned}$ & $\begin{aligned} .8072 \\
-.0333 \\
-7.7 \\
96.0\end{aligned}$ & $\begin{aligned} & .8288 \\
&-.0117 \\
&-2.7 \\
& 98.6\end{aligned}$ & $\begin{array}{l}.8380 \\
-.0025 \\
-.6 \\
99.7\end{array}$ & $\begin{aligned} .8232 \\
-.0173 \\
-4.0 \\
97.9\end{aligned}$ & -3.5 \\
\hline Inc. $620 \ldots$ & .8896 & $\begin{aligned} .8804 \\
-.0092 \\
-2 . \\
99.0\end{aligned}$ & $\begin{aligned} .8579 \\
-.0317 \\
-7.3 \\
96.4\end{aligned}$ & $\begin{aligned} & .8823 \\
&-.0073 \\
&-1.7 \\
& 99.2\end{aligned}$ & $\begin{aligned} .8897 \\
+.0001 \\
.0 \\
100.0\end{aligned}$ & $\begin{aligned} & .8738 \\
&-.0158 \\
&-3.6 \\
& 98.2\end{aligned}$ & -2.9 \\
\hline Inc. $667.8 \ldots$ & .7485 & $\begin{aligned} .7303 \\
-.0182 \\
-4.2 \\
97.6\end{aligned}$ & $\begin{aligned} .7264 \\
-.0221 \\
-5.1 \\
97.0\end{aligned}$ & $\begin{array}{r}.7441 \\
-.0044 \\
-1.0 \\
99.4\end{array}$ & $\begin{aligned} .7474 \\
-.0011 \\
-.3 \\
99.9\end{aligned}$ & $\begin{array}{l}.7394 \\
-.0091 \\
-2.1 \\
98.8\end{array}$ & -2.5 \\
\hline $\begin{array}{l}\text { Average va } \\
\text { (per cent) }\end{array}$ & of $\mathbf{A} / \mathbf{A}_{8}$ & 98.2 & 96.2 & 98.9 & 99.4 & 97.9 & \\
\hline
\end{tabular}

1 At each wave length the values given represent the following quantities:

First line, values of absorbancy, $A_{s}$ for standard values, $A$ for experimental values.

Second lines, values of $A-A_{s}$.

Third line, values of $\left(A-A_{s}\right) / 0.00434$, representing the percentage difference in the standard and observed transmittancies.

Fourth line, values of $A / A_{s}$ (per cent), at wave lengths indicated. 
TABLE 23. -Test of spectrophotometric reproducibility of chemicals for solution A, unfiltered, $2,360^{\circ} \mathrm{K}$. to mean sun; thickness, $10.00^{\circ} \mathrm{mm}$, temperature, $25^{\circ} \mathrm{C}$., age, 1 to 2 veeks. Pyridine tested for strength and amount used equivalent to standard

[Solutions prepared at Eastman Kodak Co.; spectrophotometric measurements at National Bureau of Standards]

\begin{tabular}{|c|c|c|c|c|c|c|c|}
\hline \multirow{3}{*}{$\begin{array}{l}\text { Ware length in } \\
\text { millimicrons }\end{array}$} & \multicolumn{7}{|c|}{ Spectrophotometric data 1} \\
\hline & \multirow{2}{*}{$\begin{array}{l}\text { Standard } \\
\text { ralues }\end{array}$} & \multicolumn{5}{|c|}{ Experimental ralues for solutions Nos. } & \multirow{2}{*}{$\begin{array}{l}\text { Mean } \\
1 A-2 \text { to } \\
5 A-2\end{array}$} \\
\hline & & $1 A-2$ & $2.1-2$ & $3 A-2$ & $4 \mathrm{~A}-2$ & $5 A-2$ & \\
\hline $\mathrm{Hg} 404.7 \ldots$ & 0.0502 & $\begin{array}{l}0.0599 \\
-.0097 \\
+2.2\end{array}$ & $\begin{aligned} & 0.0556 \\
+ & .0054 \\
+ & 1.2\end{aligned}$ & $\begin{aligned} & 0.1154 \\
+ & .0352 \\
+ & 8.1\end{aligned}$ & $\begin{array}{l}0.0501 \\
-.0001 \\
.0\end{array}$ & $\begin{aligned} & 0.1055 \\
+ & .0253 \\
+ & 5.8\end{aligned}$ & +3.5 \\
\hline $\mathrm{Hg} 435.5 \ldots \ldots$. & .0220 & $\begin{aligned} & .0286 \\
&+.0066 \\
&+1.5\end{aligned}$ & $\begin{array}{r}.0250 \\
+.0060 \\
-1.4\end{array}$ & $\begin{array}{r}.0464 \\
+.0244 \\
+5.6\end{array}$ & $\begin{array}{l}.0195 \\
-.0025 \\
-.6\end{array}$ & $\begin{array}{r}.0296 \\
+.0076 \\
+1.8\end{array}$ & +1.9 \\
\hline $\mathrm{Bg} \pm 91.6 \ldots \ldots \ldots$ & .1117 & $\begin{array}{l}.1105 \\
-.0012 \\
-.3\end{array}$ & $\begin{aligned} & .1130 \\
+ & .0013 \\
+ & .3\end{aligned}$ & $\begin{aligned} & .1213 \\
&+ .0096 \\
&+2.2\end{aligned}$ & $\begin{aligned} .1049 \\
-.0065 \\
-1.6\end{aligned}$ & $\begin{aligned} & .1046 \\
-.0071 & -1.6\end{aligned}$ & -.2 \\
\hline He $501.6 \ldots \ldots . . .$. & .1607 & $\begin{aligned} & .1675 \\
+ & .0071 \\
+ & .6\end{aligned}$ & $\begin{aligned} & .1594 \\
&-.0013 \\
&-.3\end{aligned}$ & $\begin{aligned} & .1725 \\
&+.0118 \\
&+2.7\end{aligned}$ & $\begin{array}{l}.1494 \\
-.0113 \\
-2.6\end{array}$ & $\begin{array}{l}.1584 \\
-.0023 \\
-.5\end{array}$ & +.2 \\
\hline Hg $546.1 \ldots$. & .5325 & $\begin{array}{l}.5307 \\
-.0015 \\
-.4 \\
99.7\end{array}$ & $\begin{array}{r}.5260 \\
-.0065 \\
-1.5 \\
98.8\end{array}$ & $\begin{aligned} .5306 \\
-.0019 \\
-.4 \\
99.6\end{aligned}$ & $\begin{array}{r}.5265 \\
-.0057 \\
-1.3 \\
98.9\end{array}$ & $\begin{aligned} & .5138 \\
&-.0187 \\
&-4.3 \\
& 96.5\end{aligned}$ & -1.6 \\
\hline $\mathrm{Hg} 575.0 \ldots \ldots \ldots$ & .7926 & $\begin{array}{r}.75 .6 \\
-.00 \equiv 0 \\
-1.2 \\
99.4\end{array}$ & $\begin{array}{r}.7530 \\
-.0096 \\
-2.2 \\
95.8\end{array}$ & $\begin{aligned} .7833 \\
-.0093 \\
-2.1 \\
98.8\end{aligned}$ & $\begin{array}{r}.7839 \\
-.0087 \\
-2.0 \\
95.9\end{array}$ & $\begin{aligned} .752 \\
-.0174 \\
-4.0 \\
97.8\end{aligned}$ & -2.3 \\
\hline He $557.6 \ldots$ & .8405 & $\begin{array}{r}.8434 \\
+.0029 \\
+.7 \\
100.3\end{array}$ & $\begin{array}{r}.8318 \\
-.0057 \\
-2.0 \\
99.0\end{array}$ & $\begin{array}{r}.83 f 2 \\
-.0043 \\
-1.0 \\
99.5\end{array}$ & $\begin{array}{r}.8415 \\
+.0040 \\
+.9 \\
100.5\end{array}$ & $\begin{array}{r}. \$ 310 \\
-.0095 \\
-2.2 \\
98.9\end{array}$ & -.7 \\
\hline Inc. $620 \ldots \ldots$ & .5596 & $\begin{array}{r}.05 s 5 \\
-.0005 \\
-.2 \\
99.9\end{array}$ & $\begin{array}{r}.8505 \\
-.0055 \\
-2.0 \\
99.0\end{array}$ & $\begin{array}{r}.85 .54 \\
-.0042 \\
-1.0 \\
99.5\end{array}$ & $\begin{array}{r}.8905 \\
+.0009 \\
.2 \\
100.1\end{array}$ & $\begin{array}{l}.8772 \\
-.0124 \\
-2.9 \\
98.6\end{array}$ & -1.2 \\
\hline Inc. $667.8 \ldots$ & .7485 & $\begin{aligned} & .7495 \\
&+.0010 \\
& .2 \\
& 100.1\end{aligned}$ & $\begin{aligned} .7433 \\
-.0052 \\
-1.2 \\
99.3\end{aligned}$ & $\begin{array}{r}.7522 \\
+.0037 \\
+.9 \\
100.5\end{array}$ & $\begin{aligned} & .7454 \\
&-.0031 \\
&-.7 \\
& 99.6\end{aligned}$ & $\begin{aligned} .7454 \\
-.0031 \\
-.7 \\
99.6\end{aligned}$ & -.3 \\
\hline $\begin{array}{l}\text { Arerage ral } \\
\text { (per cent) }\end{array}$ & of $A / A_{\text {, }}$ & 99.9 & 99.0 & 99.6 & 99.6 & 98.3 & \\
\hline
\end{tabular}

1 For esplanation of ralues, see footnote to Table 22. 
TABLE 24.-Test of spectrophotometric reproducibility of chemicals for solution $B$, filtered, $2,360^{\circ} K$. to mean sun; thickness, $10.00 \mathrm{~mm}$, temperature, $25^{\circ} \mathrm{C}$., age, 1 month

[Solutions prepared at Eastman Kodak Co.; spectrophotometric measurements at National Bureau of Standards]

\begin{tabular}{|c|c|c|c|c|c|c|c|}
\hline \multirow{3}{*}{$\begin{array}{l}\text { Ware length in } \\
\text { millimicrons }\end{array}$} & \multicolumn{7}{|c|}{ Spectrophotometric data 1} \\
\hline & \multirow{2}{*}{$\begin{array}{l}\text { Standard } \\
\text { values }\end{array}$} & \multicolumn{5}{|c|}{ Experimental ralues for solutions Nos. } & \multirow{2}{*}{$\begin{array}{l}\text { Mean } 1 \mathrm{~B} \\
\text { to } 5 \mathrm{~B}\end{array}$} \\
\hline & & $1 \mathrm{~B}$ & $2 \mathrm{~B}$ & $3 \mathrm{~B}$ & $4 \mathrm{~B}$ & $5 \mathrm{~B}$ & \\
\hline $\mathrm{Hg} 404 . \bar{i} \ldots$ & 0.0296 & $\begin{array}{l}0.0275 \\
-.0018 \\
-.4\end{array}$ & $\begin{array}{l}0.0235 \\
-.0005 \\
-.2\end{array}$ & $\begin{array}{r}0.0305 \\
+.0012 \\
+.3\end{array}$ & $\begin{aligned} & 0.0259 \\
- & .0027 \\
-. & \end{aligned}$ & $\begin{array}{r}0.0397 \\
+.0101 \\
-2.3\end{array}$ & +0.3 \\
\hline Hg $435.8 \ldots \ldots . . . .$. & .0523 & $\begin{array}{r}.0771 \\
-.0057 \\
-1.3\end{array}$ & $\begin{array}{r}.0755 \\
-.0040 \\
-.9\end{array}$ & $\begin{aligned} .0614 \\
-.0014 \\
-.3\end{aligned}$ & $\begin{array}{r}.0535 \\
+.0010 \\
+.2\end{array}$ & $\begin{array}{r}.0541 \\
+.0013 \\
+.3\end{array}$ & -.4 \\
\hline Hg 491.6........ & .2799 & $\begin{array}{l}.2646 \\
-.0133 \\
-3.5 \\
94.5\end{array}$ & $\begin{array}{l}.2203 \\
-.0095 \\
-2.2 \\
96.6\end{array}$ & $\begin{array}{r}.2511 \\
+.0012 \\
-.3 \\
100.4\end{array}$ & $\begin{aligned} .2770 \\
-.0029 \\
-.7 \\
99.0\end{aligned}$ & $\begin{array}{r}.2706 \\
-.0093 \\
-2.1 \\
96.7\end{array}$ & -1.6 \\
\hline He $501.6 \ldots \ldots . . . .$. & .3115 & $\begin{array}{r}.2006 \\
-.0209 \\
-4.8 \\
93.3\end{array}$ & $\begin{array}{l}.3006 \\
-.0109 \\
-2.5 \\
96.5\end{array}$ & $\begin{array}{r}.312 \\
+.0013 \\
+.3 \\
100.4\end{array}$ & $\begin{array}{l}.3072 \\
-.0043 \\
-1.0 \\
95.6\end{array}$ & $\begin{array}{r}.3012 \\
-.0103 \\
-2.4 \\
96.7\end{array}$ & -2.1 \\
\hline Hg $546.1 \ldots . . . . .$. & $.1 \times 52$ & $\begin{array}{r}.1776 \\
-.0076 \\
-1.8 \\
95.9\end{array}$ & $\begin{aligned} & .1501 \\
&-.0051 \\
&-1.2 \\
& 9 \div .2\end{aligned}$ & $\begin{array}{r}.1916 \\
+.00074 \\
+1.5 \\
103.5\end{array}$ & $\begin{aligned} & .1521 \\
&=.0031 \\
& 9.7\end{aligned}$ & $\begin{array}{l}.1530 \\
-.0022 \\
-.5 \\
95.8\end{array}$ & -.5 \\
\hline $\mathrm{Hg} 578.0 \ldots$ & .0905 & $\begin{aligned} & .0559 \\
-.0037 & -.9\end{aligned}$ & $\begin{aligned} .0575 \\
-.0025 \\
-.6\end{aligned}$ & $\begin{array}{r}.0920 \\
+.0014 \\
+.3\end{array}$ & $\begin{aligned} .0595 \\
-.0006 \\
-.2\end{aligned}$ & $\begin{aligned} .0593 \\
-.0013 \\
-.3\end{aligned}$ & -.3 \\
\hline He $557.6 \ldots$ & .0971 & $\begin{aligned} .0952 \\
-.0019 \\
-.4\end{aligned}$ & $\begin{aligned} & .0945 \\
&-.0023 \\
&-.5\end{aligned}$ & $\begin{array}{l}.08644 \\
-.0007 \\
-.2\end{array}$ & $\begin{array}{r}.0995 \\
+.0024 \\
+.6\end{array}$ & $\begin{array}{l}.0384 \\
+.0013 \\
+.3\end{array}$ & .0 \\
\hline Inc. 620 & .1742 & $\begin{array}{r}.1751 \\
+.0009 \\
+.2 \\
100.5\end{array}$ & $\begin{aligned} .1764 \\
+.0022 \\
+.5 \\
101.3\end{aligned}$ & $\begin{array}{c}.1763 \\
+.0021 \\
+.5 \\
101.2\end{array}$ & $\begin{array}{l}.1752 \\
+.0040 \\
+.9 \\
102.3\end{array}$ & $\begin{aligned} & .1772 \\
&+ 0030 \\
&+.7 \\
& 101.7\end{aligned}$ & +.6 \\
\hline Inc. $667.8 \ldots$ & .4500 & $\begin{aligned} .4414 \\
-.0035 \\
-2.0 \\
98.1\end{aligned}$ & $\begin{array}{l}.4465 \\
-.003 \% \\
-.8 \\
99.2\end{array}$ & $\begin{aligned} & .4492 \\
&-.0008 \\
&-.2 \\
& 99.8\end{aligned}$ & $\begin{array}{c}.4513 \\
+.0013 \\
-.3 \\
100.3\end{array}$ & $\begin{aligned} .4521 \\
-.0021 \\
+.5 \\
100.5\end{aligned}$ & -.4 \\
\hline \multirow{2}{*}{\multicolumn{2}{|c|}{$\begin{array}{l}\text { A rerage ralues of } \mathrm{A} / \mathrm{A}, \\
\text { (per cent): } \\
\text { Cobalt (mean of } 491.6, \\
501.6, \text { and } 546.1 \mathrm{m \mu})= \\
\text { Copper (weighting } \\
667.8 / 620=21)=\end{array}$}} & 94. 6 & 96.8 & 101.4 & 95.6 & $9 \pi .4$ & \\
\hline & & 95.9 & 99.9 & 100.3 & 101.0 & 100.9 & \\
\hline
\end{tabular}

1 For explanation of ralues, see footnote to Table 22.

Item (4) above illustrates the percentage effect of the deriations on the energy distribution of the source-and-filter combination; item (5) affords a spectrophotometric analrsis of the relative copper or cobalt content of the solutions, as qualified below.

A summary of the analyses of these three sets of solutions is giren in Table 25. Explanations for the larger discrepancies in Tables 22 to 24 between the standard spectrophotometric data and the ralues obtained with these solutions become immediately obrious. The following cases should be noted in particular:

1. Solution 2A.-The prridine was yellow and of but 92 per cent strength in the solution. As noted elsewhere, it requires about 6 per 


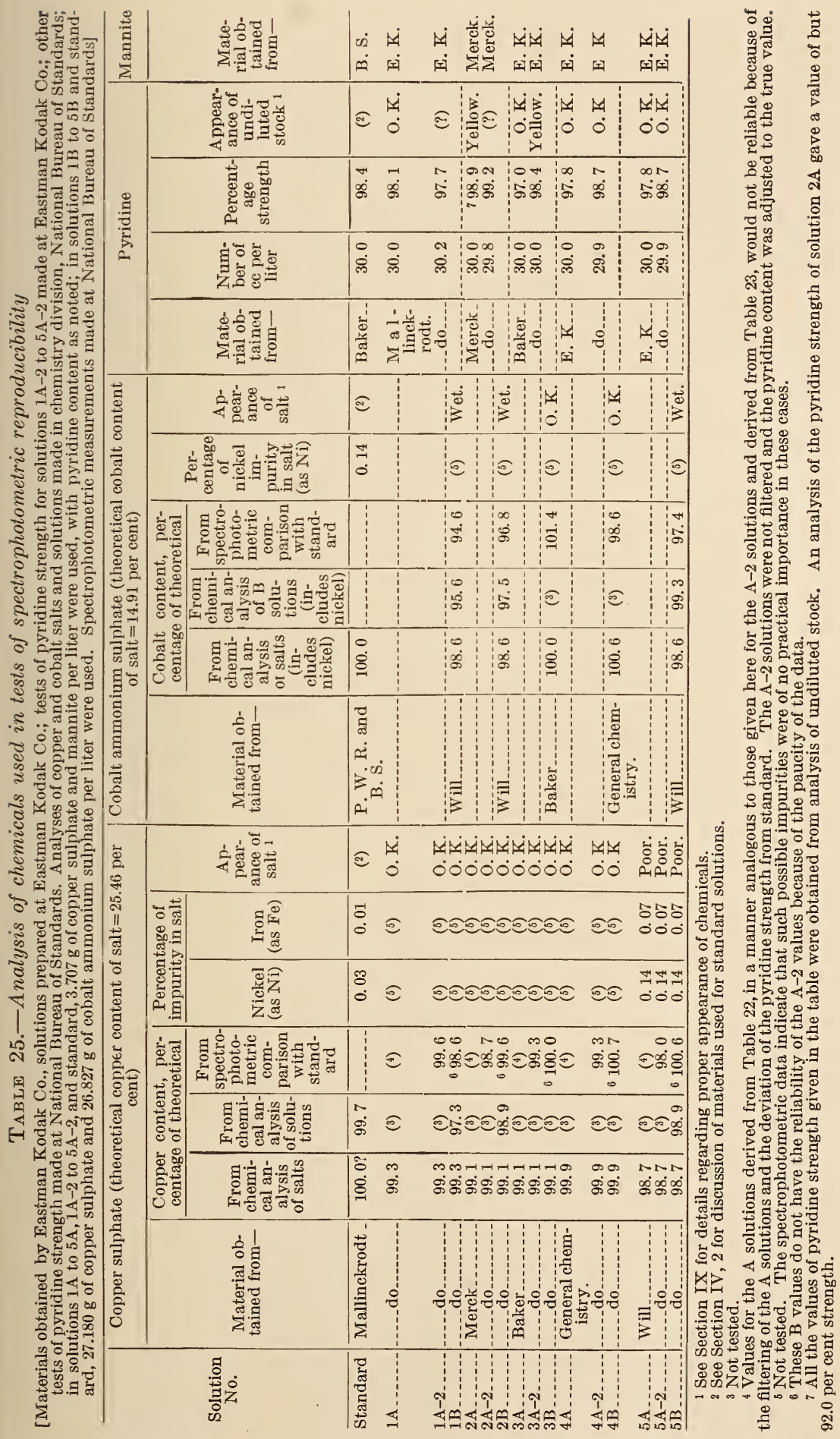


cent error in pyridine strength to equal 1 per cent error in copper strength. Since this solution is about 4 per cent weak (in copper content or its equivalent) the pyridine weakness is not the sole explanation of the discrepancy. However, as noted above, this and the other $A$ solutions ( $1 \mathrm{~A}$ to $5 \mathrm{~A}$ ) were filtered. In view of the fact that the filter paper is liable to remove some of the copper (Secs. VII, 2, (b) and IX), no further explanation of the copper weakness in these A solutions should be necessary. It is to be emphasized that these data of Table 22 can not be used to show lack of reproducibility in the Davis-Gibson filters.

2. Solution 3A-2.-The pyridine used was yellow. Spectrophotometric analysis of this pyridine (Sec. VII, $9(d)$ ) showed that this cause would explain about half of the relatively large deviations in the transmittancies at $404.7 \mathrm{~m} \mu$ and $435.8 \mathrm{~m} \mu$. The reason for the lack of such deviation in solution $2 \mathrm{~A}$ is not clear.

3. Solutions 1A-2, 2A-2, and 3A-2.-The remaining discrepancy at $404.7 \mathrm{~m} \mu$ with solution $3 \mathrm{~A}-2$ and other positive deviations at this wave length would be adequately explained by assuming small amounts of picoline impurity in the pyridine. (Sec. VII, $9(b)$.) This, however, would not explain the positive deviation at $404.7 \mathrm{~m} \mu$ in the case of the $5 \mathrm{~A}-2$ solution as the same pyridine was used here as in the $4 \mathrm{~A}-2$ solution.

4. Solutions 5A, 5A-2, and 5B.-The deviations at $404.7 \mathrm{~m} \mu$ and to a less extent at $435.8 \mathrm{~m} \mu$ indicate quite certainly a common source of trouble. An analysis of the copper sulphate, common to all three solutions, showed a relatively high proportion of nickel and iron impurities. No study of nickel sulphate in pyridine solution has been made, nor of iron solutions with or without pyridine. The analyzed impurity of nickel would cause barely +1 per cent error at $404.7 \mathrm{~m} \mu$ in the $\mathrm{B}$ solution, compared with the observed +2.3 per cent error. (The cobalt component of solution $5 \mathrm{~B}$ is common to $1 \mathrm{~B}$ and $2 \mathrm{~B}$, which shows that nickel impurity in the cobalt can not contribute appreciably to this 2.3 per cent.) While no certain conclusion can thus be drawn, it is believed that the discrepancies at $404.7 \mathrm{~m} \mu$, allowing for the usual spectrophotometric uncertainty, could be adequately accounted for by the impurities of this sample of copper sulphate. As noted in Table 25 its general appearance was quite inferior, and the chemical and spectrophotometric analysis (solution $5 \mathrm{~A}-2$ and possibly $5 \mathrm{~A}$ ) indicate copper weakness of 1 or 2 per cent. It is reasonably certain that solutions $5 \mathrm{~A}$ and $5 \mathrm{~A}-2$ were not weak in pyridine because the same supplies were used as in solutions $4 \mathrm{~A}$ and $4 \mathrm{~A}-2$, respectively, which showed much smaller deviations.

5. Solutions $1 B, 2 B$, and $5 B$.-The same lot of cobalt ammonium sulphate was used in preparing these solutions. The salt was distinctly wet, adhering to the sides of the bottle. Analysis of the salt showed 98.6 per cent of the theoretical cobalt content. However, chemical analysis of the three solutions (Table 25) gave cobalt contents which account for most of the discrepancies, the chemical and spectrophotometric analyses agreeing to about 1 per cent in two of the three cases.

If the data be rejected for those solutions in which yellow pyridine, wet cobalt ammonium sulphate, or inferior looking copper sulphate were used (in addition to the filtered A solutions), the remaining solutions show a very satisfactory degree of reproducibility. It is 
true that the pyridine used in solutions $1 \mathrm{~A}-2$ to $5 \mathrm{~A}-2$ was tested and adjusted for strength, but it is also true that the total variation in strength in these and the pyridines used in solutions $1 \mathrm{~A}$ to $5 \mathrm{~A}$, as tested in the undiluted stock, varied only from 97.0 to 99.0 per cent. The total variation in all the samples of pyridine examined during this investigation, 17 in number, varied only from 97.0 to 100.0 per cent or \pm 1.5 per cent approximately from the 98.4 per cent taken as standard. As stated above, 6 per cent variation in pyridine is practically equivalent to a 1 per cent variation in copper content; and 1.5 per cent variation in pyridine causes less than 1 per cent variation in transmittancy at the wave length $(587.6 \mathrm{~m} \mu$, approximately) where this variation is the greatest.

Excluding the solutions just noted leaves Nos. 1A-2, 2A-2, 4A-2, $3 \mathrm{~B}$, and $4 \mathrm{~B}$ as representative of what may be expected when materials are used without chemical or spectrophotometric analysis, but when certain precautions are used in the specifications and choice of the materials and when the A solution is not filtered. The maximum deviations in transmittancy of the observed from the standard computed values are from 1 to $1 \frac{1}{2}$ per cent for the B solutions and from 2 to $2 \frac{1}{2}$ per cent for the A solutions. Furthermore, little increase in these maximum deviations are noticeable if data from the rejected solutions be included at those wave lengths where the objections stated do not apply-for example, (1) with solutions $1 \mathrm{~A}$ to $4 \mathrm{~A}$ from $404.7 \mathrm{~m} \mu$ to $501.6 \mathrm{~m} \mu$, where loss of copper strength by filtering would be barely noticeable; (2) with solution $3 \mathrm{~A}-2$ at the longer wave lengths, where the yellow pyridine has practically no absorption when diluted to 30 cc per liter; (3) with solutions $1 \mathrm{~B}$ and $2 \mathrm{~B}$ at $404.7 \mathrm{~m} \mu$ and $435.8 \mathrm{~m} \mu$ and above $546.1 \mathrm{~m} \mu$, where variations of a few per cent in cobalt content would be of no importance.

It will be noticed that the region where the B solution is most apt to be in error is in the green, including particularly the $491.6 \mathrm{~m} \mu$ and $501.6 \mathrm{~m} \mu$ lines, in which region the $\mathrm{A}-2$ solution is on the average the least in error. Therefore, the combination of the A and B solutions (prepared from properly chosen materials as noted just above) will give for the complete filter a maximum deviation little if any greater than is given by the A solution alone; for example, the combination of either $3 \mathrm{~B}$ or $4 \mathrm{~B}$ with either $1 \mathrm{~A}-2,2 \mathrm{~A}-2$, or $4 \mathrm{~A}-2$ gives a maximum deviation of $2 \frac{1}{2}$ per cent, excepting only in one case $(4 \mathrm{~A}-2+4 \mathrm{~B}$ at $501.6 \mathrm{~m} \mu$ ) where a $3 \frac{1}{2}$ per cent deviation is obtained.

These maximum deviations compare favorably with those obtained when a completed $2,360^{\circ} \mathrm{K}$. filter was examined spectrophotometrically (Sec. VIII, 1), the same materials having been used in preparing the completed filter as were used in deriving the adopted data, and are not certainly outside of the combined spectrophotometric uncertainties. Filters using lower concentrations would be subject to still less uncertainty. With due consideration for the source and appearance of the materials, therefore, as summarized in Section IX, it would seem that filters can readily be prepared whose resulting energy distributions will not deviate from those herein given by more than 2 or 3 per cent.

Two other items of interest regarding the reproducibility of pyridine may be noted.

1. A new supply of pyridine was obtained at the bureau in 1929 from Eastman Kodak Co., titrating 97.7 per cent strength. 
will be recalled that the standard absorbancy data for solution $\mathrm{A}^{\prime}$, as illustrated in Tables 4 and 18, were obtained with pyridine from Baker Chemical Co. which was of 98.4 per cent strength.) An A' solution was prepared, No. 65-24, using the same copper sulphate as used throughout the investigation and with the new pyridine- $3 \mathrm{~g}$ of copper sulphate, $3 \mathrm{~g}$ of mannite, and $30 \mathrm{cc}$ of pyridine per liter of solution. Spectrophotometric measurements on this solution made three weeks after preparation gave, at every wave length tested (Table 18, column 15), values agreeing with the adopted standard values to better than 1 per cent of the transmittancy.

2. The following statement, to which reference has been made in Section IV, 2, appeared in a memorandum (15 Great Britain 1) submitted under date of June 13, 1929, by the subcommittee on colorimetry of the National Illumination Committee of Great Britain:

Several of the Davis-Gibson filters have been made up at the National Physical Laboratory using c. p. pyridine obtained from commercial dealers without taking any precautions about purity. The properties of these filters agreed so closely with those published by Davis and Gibson that we may conclude, so far as Great Britain is concerned, that pyridine can be obtained commercially of sufficient purity to obviate the need for any elaborate precautions.

\section{AUXILIARY DATA}

(a) AQUEOUS PYRIDINE SOLUTION OF COBALT SULPHATE

A solution containing $6.000 \mathrm{~g}$ (supposedly) of $\mathrm{CoSO}_{4} \cdot 7 \mathrm{H}_{2} \mathrm{O}$, 30.0 cc of pyridine, and distilled water to a total of 1 liter, was prepared and filtered, No. 61-12, and spectrophotometric measurements made from one to three weeks after preparation. Visual, photoelectric, and thermoelectric methods were used, with thicknesses of 20,40 , and $100 \mathrm{~mm}$. The adopted values are illustrated in Figure 26 in comparison with the standard $\mathrm{B}_{2}{ }^{\prime}$ solution. They are not tabulated because of the uncertainty in the cobalt content. (Sec. IV.)

\section{(b) AQUEOUS a-PICOLINE SOLUTION OF COPPER SULPHATE WITH MANNITE}

It was noted in Section IV, 2 that the commonest impurity of importance apt to be present in pyridine is a-picoline, the pyridine used in the standard solutions having a picoline impurity of about $2 \frac{1}{2}$ per cent. The effect of the picoline was studied in two ways: (1) As an impurity, $3 \mathrm{~g}$ copper-sulphate (with mannite) solutions being prepared, containing, respectively, by volume, 0,5 , and 10 per cent of picoline in the pyridine; (2) without pyridine, a $3 \mathrm{~g}$ copper sulphate (with mannite) solution being prepared, containing $35 \mathrm{cc}$ of picoline (the molecular equivalent of 30 cc of pyridine) per liter of aqueous solution.

The results obtained are shown in Figure 27. The most striking differences between the pyridine and the picoline solutions are the general shift of the latter curve toward longer wave lengths and the notable increase in its absorbancy at $404.7 \mathrm{~m} \mu$.

This marked change in absorbancy at $404.7 \mathrm{~m} \mu$ affords a sensitive method of analysis of the picoline impurity in pyridine. It will be noticed that in the green, yellow, and red the effect of the picoline is not very marked and, such as it is, is very similar to the change produced by a simple weakening of the pyridine strength (fig. 24); 
but the change at $404.7 \mathrm{~m} \mu$ produced by the picoline is in striking contrast to the very small change occurring at this wave length when the pyridine content is varied.

On the basis of the measurements at $404.7 \mathrm{~m} \mu$ with the solutions containing 0,5 , and 10 per cent of picoline impurity (fig. 27), the standard solution had 21.2 per cent of such impurity, and within the

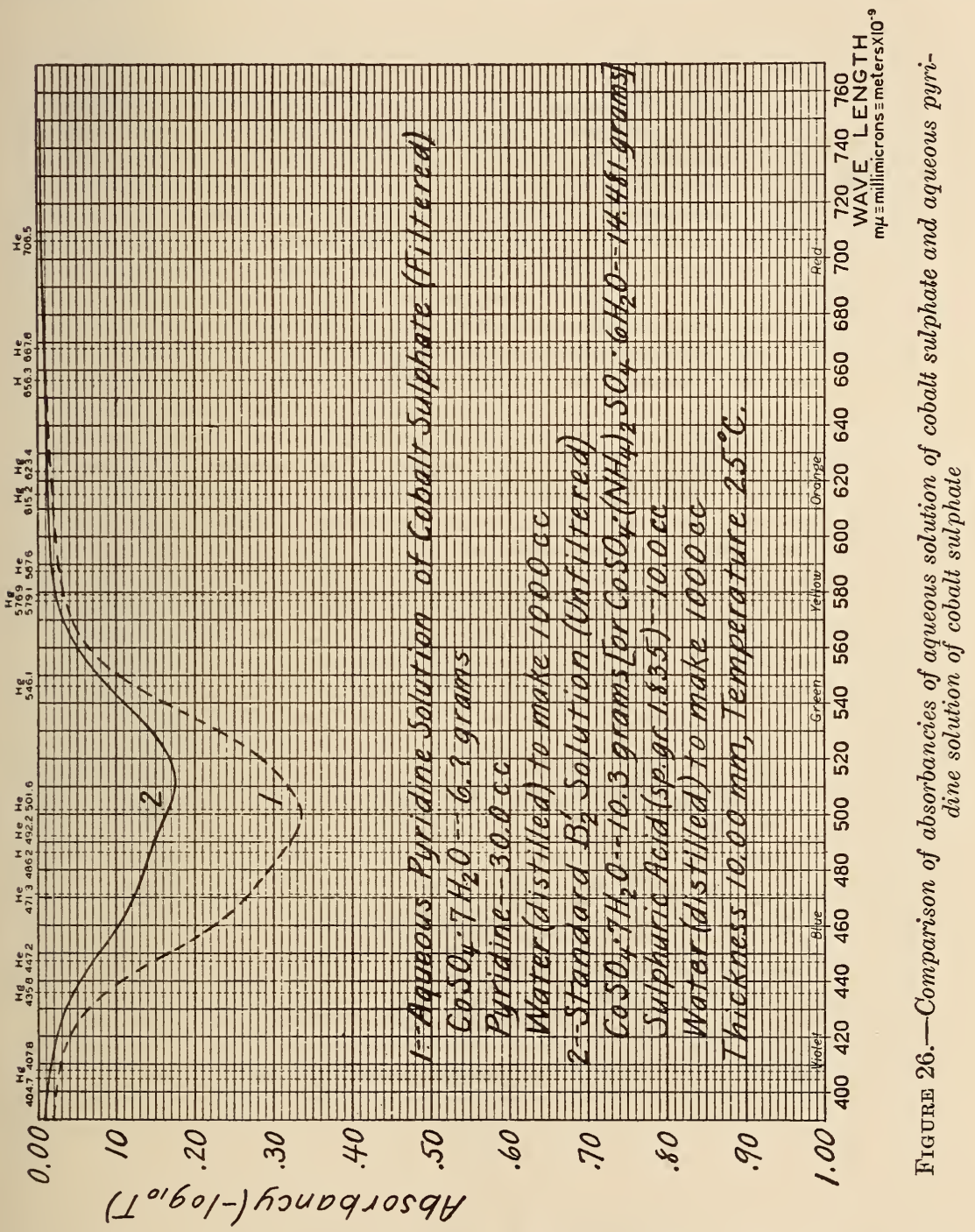

observational uncertainty this value is checked by consideration of the data from $546.1 \mathrm{~m} \mu$ to $620 \mathrm{~m} \mu$, inclusive. It may be noted that the changes in absorbancy produced by the small amounts of picoline are not as great proportionately as are indicated by the 100 per cent picoline solution, even when reduced to a $30 \mathrm{cc}$ basis.

The data discussed in Section VII, 8 show that $a$-picoline impurity in colorless commercial pyridine as great as 5 per cent has not been 
found in this investigation. a-Picoline impurity between 0 and 5 per cent will cause deviations from the standard data of less than 3 per cent of the transmittancy at $404.7 \mathrm{~m} \mu$ and of less than 1 per cent at all wave lengths in the visible spectrum above $430 \mathrm{~m} \mu$. Under most circumstances its effect, therefore, may be ignored.

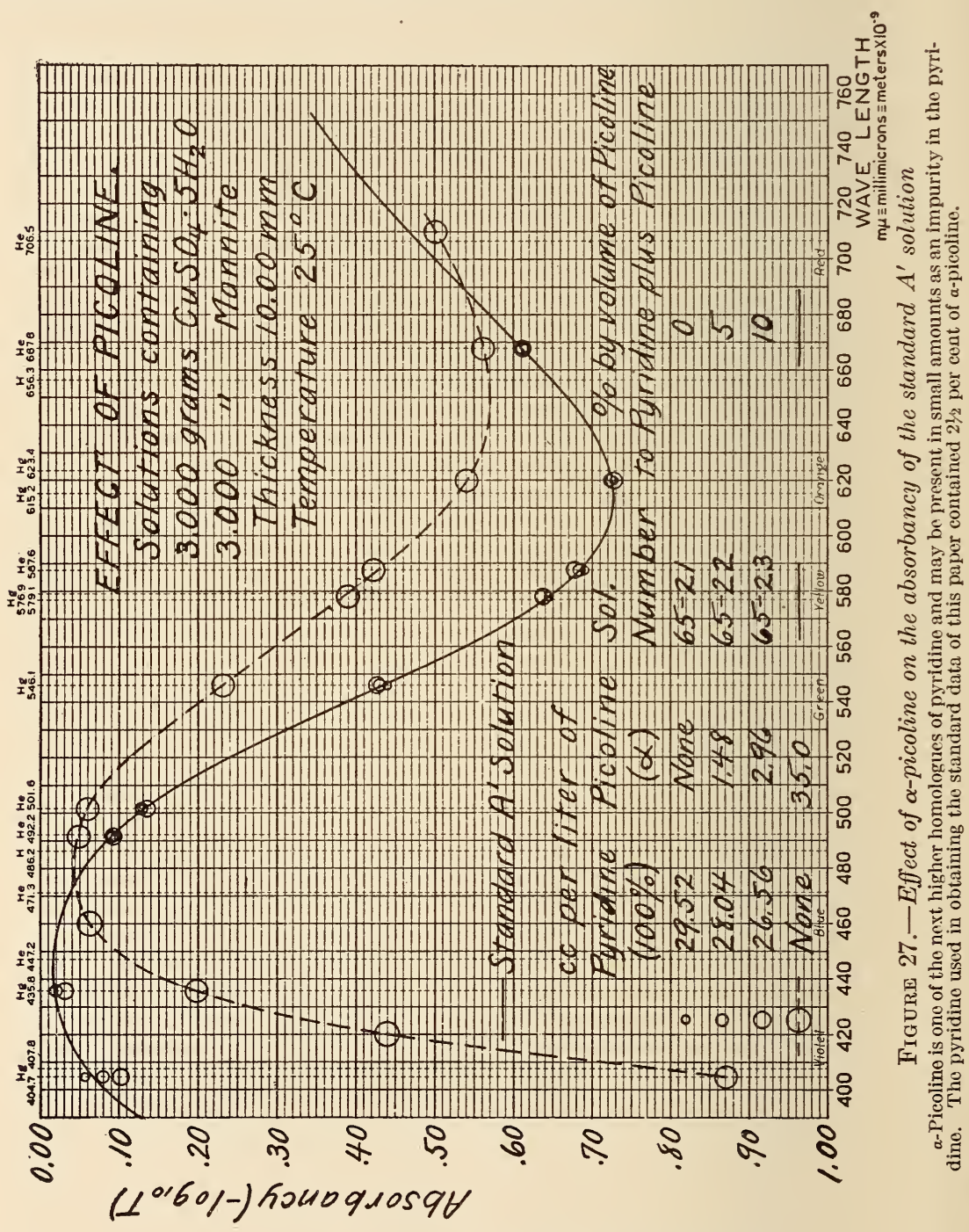

(c) AQUEOUS SOLUTION OF NICKEL SULPHATE

Nickel sulphate has a well-known characteristic transmittancy curve with maximum transmission in the green and ultra-violet and maximum absorption in the extreme violet and red. As an important impurity in cobalt sulphate and cobalt ammonium sulphate, it is of interest to determine its maximum selectivity in very weak solution; that is, the ratio of its transmittancy in the violet to that in the green. 
Accordingly a solution, No. $61-1$, containing $1.000 \mathrm{~g}$ of $\mathrm{NiSO}_{4} \cdot 6 \mathrm{H}_{2} \mathrm{O}$ per liter was prepared and measurements made visually, photoelectrically, and thermoelectrically. The measurements were not extensive, but sufficient data were obtained to indicate that the ratio of minimum to maximum transmittancy was certainly not less than 0.950 .

If nickel were present in cobalt ammonium sulphate in the proportion of nickel to cobalt of 1 to 100 , the concentration of nickel sulphate present in the standard $\mathrm{B}_{2}{ }^{\prime}$ solution would be approximately $0.1 \mathrm{~g}$ per liter. The value of the ratio above indicated will in this case probably not be less than 0.995, amounting to one-half per cent selectivity, and for the cobalt as analyzed and used about onequarter per cent. This small amount is, of course, negligible, so that if the nickel to cobalt (metals) proportion varies from zero to 1 per cent, no important error is introduced.

\section{(d) AQUEOUS SOLUTION OF PYRIDINE}

Two samples of pyridine were examined spectrophotometrically. One of these samples was from the stock used throughout most of the investigation, practically colorless and shown by analysis to be of 98.4 per cent strength. (Sec. IV, 2.) In a $10 \mathrm{~mm}$ thickness of a 3 per cent aqueous solution (that is, 30 cc per liter, as used in the filters), this shows a maximum variation in transmittancy between $404.7 \mathrm{~m} \mu$ and $700 \mathrm{~m} \mu$ of but 0.2 per cent. This value was derived from measurements made on the full-strength material in a $100 \mathrm{~mm}$ thickness. Values for $10 \mathrm{~mm}$ are plotted in Figure 28 .

The other sample tested was the yellow pyridine used in solution $3 \mathrm{~A}-2$. (Sec. VII, 8.) It was examined in a 10 and $20 \mathrm{~mm}$ thickness, full strength, and in a $100 \mathrm{~mm}$ thickness, 3 per cent strength. Values for 3 per cent strength were computed from the full-strength measurements, assuming Beer's law, and showed good agreement with those obtained directly on the 3 per cent strength solution. The average values are plotted in Figure 28. A maximum selectivity of 3.3 per cent may be noted.

It is obvious that if the strongly colored yellow pyridine be avoided and only that used in preparing A solutions which is practically colorless, showing no more than a trace of yellow, no error of any importance can result from the color of the pyridine.

\section{(e) AQUEOUS SOLUTION OF SULPHURIC ACID}

Sulphuric acid is present in the $B_{1}, B_{2}$, and $B$ solutions in the proportion of $10 \mathrm{cc}$ per liter. It was of interest to see if a sulphuricacid solution of this strength showed any selectivity. A solution was prepared containing $100 \mathrm{cc}$ per liter, or ten times the strength used in the standard solutions. A single set of measurements was made, at $404.7 \mathrm{~m} \mu, 435.8 \mathrm{~m} \mu, 546.1 \mathrm{~m} \mu, 578.0 \mathrm{~m} \mu$, and $700 \mathrm{~m} \mu$. Values of transmittancy thus obtained, in a $10 \mathrm{~mm}$ cell, differed from unity nowhere more than 1 per cent. The selectivity of the dilute sulphuric acid as used in the $\mathrm{B}_{1}, \mathrm{~B}_{2}$, and $\mathrm{B}$ solutions is therefore negligible. 


\section{USE OF SOLUTIONS AND DATA IN SPECTROPHOTOMETRIC CALIBRATION}

The discrepancies which may be obtained when the same or duplicate samples are measured spectrophotometrically on different apparatus has been well illustrated in a recent publication (53). To one who has available but a single instrument or method of measurement it may not be apparent that, along with the excellent precision and

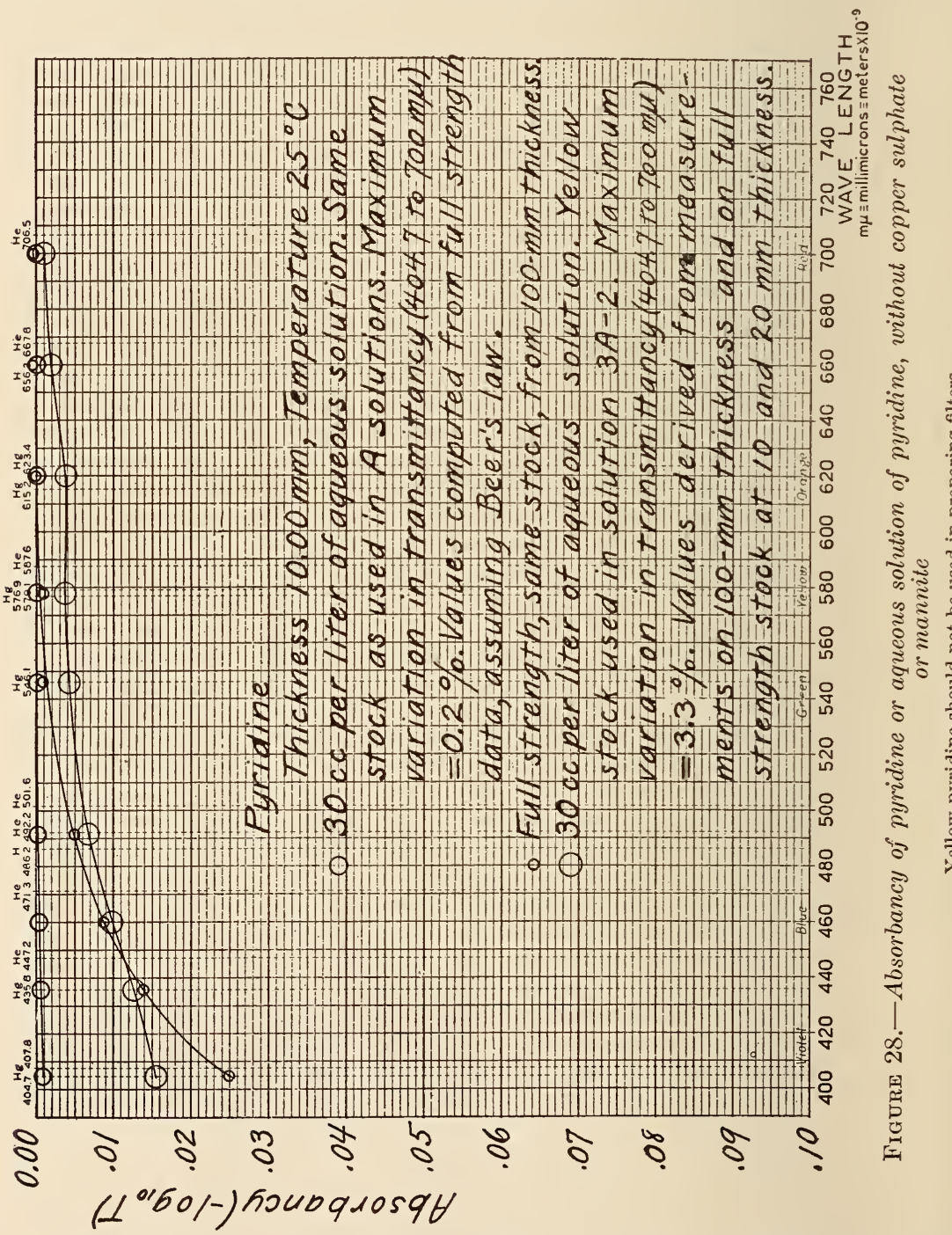

the high degree of reproducibility which he may be obtaining, serious errors of measurement are, perhaps, entering into his data.

Such errors may result from stray light or energy, from impure spectra caused by the use of too wide slit widths, from inaccurate wave-length calibration, and from temperature changes occurring in 
the sample during measurement. The magnitude of such errors depends greatly on the particular sample being measured. In addition the photometric scale-nicol prisms, variable sector, moving wedge, inverse-square law, etc.-may for one reason or another not be functioning in its nominal manner. It may be inaccurate throughout or at certain places only. In measuring transmission samples the introduction of the sample may change the focus or optical distance or displace the beam so that, in effect, a different source is being used when the sample is in the beam than when it is removed. Unless the source is of uniform brightness and of sufficient extent this may cause considerable error. Reflection measurements made on different apparatus will differ because of differing conditions of illumination and observation, and permanent changes may. take place in the sample during measurement if subject to excessive radiant energy. Furthermore, practically every instrument or apparatus has troubles or uncertainties peculiar to itself which require constant attention to avoid the introduction of error.

General familiarity with the subject of spectrophotometry is, of course, of great help in securing reliable transmissive and reflective data. The Optical Society of America Report on Spectrophotometry (35) should assist in this respect. Detailed study of one's particular apparatus should, of course, also be made. A third method often used in attempting to verify the reliability of spectrophotometric data is to send colored glass samples to the bureau for calibration. The spectral transmissions reported by the bureau are then taken as standard values, and by measuring the samples on his own apparatus one can readily locate serious errors of measurement.

It is believed that the standard solutions used in the present investigation can be used in this manner. They have been very carefully analyzed and measured as indicated elsewhere in the paper. The series is incomplete for this purpose in that no solution is present which absorbs strongly in the blue. With this exception, by varying the thickness of the solutions, values of absorbancy or transmittancy may be obtained of almost any magnitude at any wave-length region in the visible spectrum.

The data of Tables 4, 5, and 6 only should be used for this purpose. These data do not involve any Beer's law failure. They are standard at $25^{\circ} \mathrm{C}$, and any deviation from this temperature may be corrected for by the data of Table 16 . The uncertainty of the data is indicated in Section VII, 7. The data apply to $10 \mathrm{~mm}$ thicknesses, and the uncertainty in the absorbancy values will increase with the thickness. If one is unable to analyze his chemicals or solutions, the resulting uncertainty must be allowed for. The questions of choice, analysis, and reproducibility of materials is discussed in Sections IV, VII, 8, and IX.

\section{EXAMINATION AND TRIAL OF COMPLETED FILTERS}

In Section VII was given in considerable detail a description of the methods used and the data outlined in the spectrophotometric study of the filter components. This included absorbancy measurements on solutions $\mathrm{A}^{\prime}, \mathrm{B}_{1}{ }^{\prime}, \mathrm{B}_{2}{ }^{\prime}$, and $\mathrm{B}^{\prime}$ and density measurements on the double glass cell filled with water, a study of Beer's law over the range of concentrations used, the measurement of time and tempera- 
ture effects, and of the effect of variation of pyridine content (on the $\mathrm{A}^{\prime}$ solution), a discussion of the reliability of the spectrophotometric data, and tests of the spectrophotometric reproducibility of the chemicals. The information therein given has permanent value so far as these solutions are concerned not only as regards their use in filters, but also in connection with their use as standards in spectrophotometric calibration or chemical analysis.

In the present section the influence on the completed filters of the time and temperature effects is computed along with certain other effects which can be most advantageously considered in this manner, and, in addition, various direct experimental checks on the completed filters are described.

\section{SPECTROPHOTOMETRIC MEASUREMENTS}

Using the same chemicals and the same glass plates as were used in the measurements described in Section VII, three different filters were prepared and tested, viz, $2,360^{\circ} \mathrm{K}$. to mean sun, $2,848^{\circ} \mathrm{K}$. to Abbot-Priest sun, and $4,000^{\circ} \mathrm{K}$. to mean sun, the respective solutions being approximately, 3,3 , and 7 weeks old at the time of the measurements. The concentrations thus used are fairly representative of the two extremes and the medium of the concentrations used in the filters of Series I and II, and the first of these filters is, furthermore, of special interest in its application.

Measurements were made solely on the Koenig-Martens spectrophotometer using the mercury and the incandescent light sources, with other experimental conditions as usual. It was not possible, however, to maintain any temperature control over the filters as had been done with the solutions, because the apparatus for temperature control was not designed to accommodate specimens as large as the filters. The temperature of the air near the filter deviated in extreme cases by $5^{\circ}$ or $6^{\circ}$ from $25^{\circ} \mathrm{C}$., but in such cases measurements were repeated on days when the temperature of the air deviated from the standard in the opposite direction, so that the temperature effect was partially eliminated. No attempt was made to correct the data on the basis of the temperature corrections established in Section VII, 4, as it was uncertain just how truly the temperature of the air near the cell represented that of the filter solutions. Probably on the average the filter temperatures were somewhat in excess of $25^{\circ} \mathrm{C}$.

The results of this experimental check are given in Table 26. For each of the three filters are given as a function of wave length, the percentage differences between the transmissions as computed and tabulated in the respective charts and those experimentally determined; that is,

$$
\frac{T_{s}-T_{\text {exp }}}{T_{s}} \times 100
$$

The value given may come from one or two determinations as is the case for the $4,000^{\circ} \mathrm{K}$. filter or from one to five determinations as is the case for the other two filters. In averaging two or more determinations at any wave length, equal weights were used.

Deviations less than 1 per cent can not be considered of much significance unless possibly when carrying consistently over a certain 
wave-length range for all three filters. The following cases may be noted particularly:

1. At $404.7 \mathrm{m \mu}$ and $435.8 \mathrm{~m} \mu$.-These values undoubtedly result from lack of temperature control. For example, at $404.7 \mathrm{~m} \mu$ with the $2,360^{\circ} \mathrm{K}$. filter, values of transmission were obtained varying from 0.661 , air temperature $31^{\circ} \mathrm{C}$., to 0.704 , air temperature $23.5^{\circ} \mathrm{C}$. Furthermore, the differences at $420 \mathrm{~m} \mu$ (single determinations, at air temperatures from $24.5^{\circ}$ to $28^{\circ}$ C.) of opposite sign in two of the three cases, although of less precision, make practically certain that no important error can be present in this region.

2. From $480 \mathrm{~m} \mu$ to $510 \mathrm{~m} \mu$, inclusive.-The temperature effect is very small in this region. The deviations average about 0.8 per cent, all of the same sign without exception. This may be significant, but can not be considered important.

3. From $610 \mathrm{~m} \mu$ to $660 \mathrm{~m} \mu$.- The deviations average about $1.3 \mathrm{per}$ cent, all of one sign without exception, those for the $2,360^{\circ} \mathrm{K}$. filter running over 2 per cent. From $610 \mathrm{~m} \mu$ to $630 \mathrm{~m} \mu$ the temperature effect is small, changing sign near $620 \mathrm{~m} \mu$.

TABLE 26.-Comparison of standard computed values of transmission $\left(T_{s}\right)$ as given in the charts with values experimentally determined $\left(T_{\text {exp }}\right)$, using the same chemicals and glass plates in the latter case as were used in determining the standard values

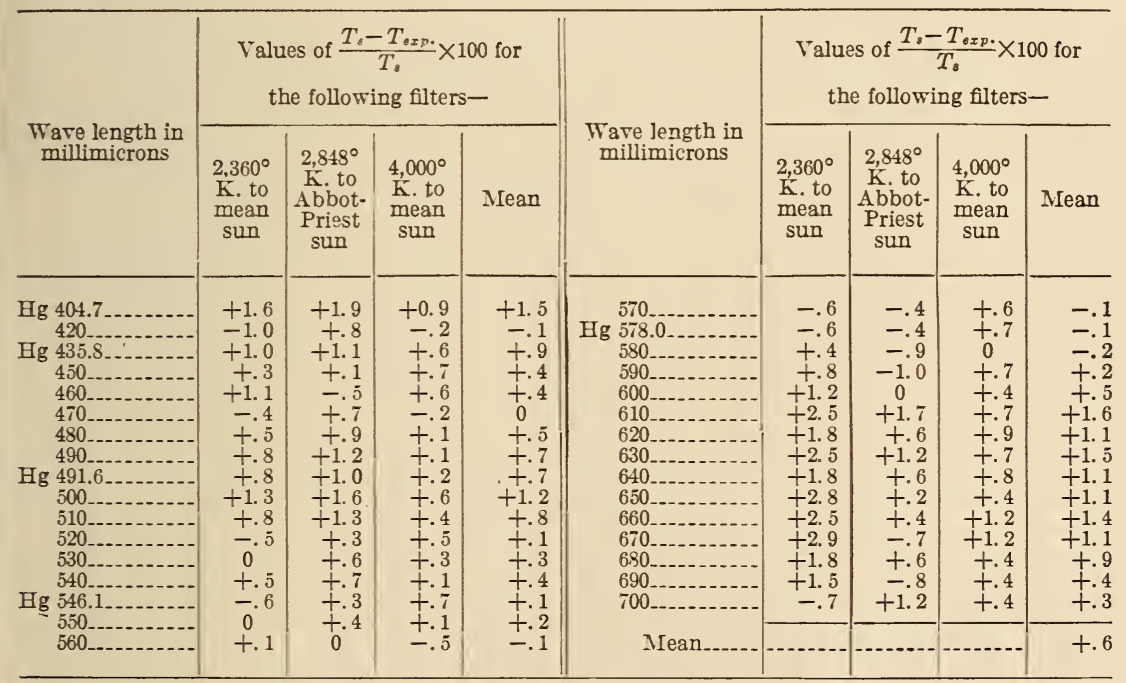

4. The final mean value.-This arerage, +0.6 per cent, illustrates the tendency of the values to be positive.

The discrepancies illustrated in Table 26 may be considered from two standpoints- $(a)$ their reasonableness from the spectrophotometric standpoint, assuming no change in the chemicals and no error in preparing the solutions, $(b)$ their connection, if any, with the results obtained with solutions prepared from other chemicals.

(a) The uncertainty estimated in the standard data for solutions $\mathrm{A}^{\prime}$ and $\mathrm{B}^{\prime}$ was in each case from $1 / 4$ to $1 / 2$ per cent of the transmittancy from 404.7 to $667.8 \mathrm{~m} \mu$, and $1 / 2$ per cent of the transmission 
for the cell filled with water. In addition, must be included the uncertainty resulting from any error in the Beer's law correction. A maximum uncertainty of approximately 1 per cent is therefore to be expected in the standard computed values $\left(T_{s}\right)$ from which the percentage deviations of Table 26 were derived.

Regarding the Beer's law correction factor, it has been shown in Section VII, 6 and Figure 25 that the only region in which any reasonable error could exert an appreciable effect on the computed values was in the red. Such possible errors can not be the principal explanation of the deviations shown in the red region of Table 26 , for in that case values for the $2,360^{\circ} \mathrm{K}$. and the $4,000^{\circ} \mathrm{K}$. filters would be of opposite sign.

The experimentally determined values $\left(T_{\text {cxp }}\right)$ can not be considered reliable in general to better than 1 per cent. With the incandescent light source but one or two deterninations were made. As many as five determinations were made in some cases with the mercury lines, but because of the temperature variations the final values did not have the usual reliability.

The possible combined uncertainties of the computed and experimental values are, therefore, sufficient to explain most of the deviations in Table 26; that is, all those less than 2 per cent. In the red, with the $2,360^{\circ} \mathrm{K}$. filter, the computed values are probably more reliable than the directly determined values; in fact, a 2 per cent error in these latter would not be surprising. It must be remembered that the transmission in this case is low, varying from about 0.08 at $610 \mathrm{~m} \mu$ to about 0.04 at $700 \mathrm{~m} \mu$. The 2.5 per cent deviation at $610 \mathrm{~m} \mu$ equals

$$
\frac{0.0834-0.0813}{0.0834} \times 100
$$

and the 2.8 per cent deviation at $650 \mathrm{~m} \mu$ equals

$$
\frac{0.0646-0.0628}{0.0646} \times 100
$$

While, therefore, it is not to be expected that the computed values of spectral transmission given on the charts are without error, it would take further work to prove conclusively that they were in error by as much as 1 per cent, for the particular chemicals used in this investigation.

(b) The spectrophotometric uncertainty discussed abore is somewhat less than may be caused by variations in the materials when obtained from various sources unless due care is taken in the selection of these materials. This question of reproducibility has been discussed in Section VII, 8. It is noted again merely to point out the fact that the tendency for the computed values of transmission to be high from $610 \mathrm{~m} \mu$ to $680 \mathrm{~m} \mu$, as illustrated in Table 26, was not found in the case of the $2,360^{\circ} \mathrm{K}$. solutions measured in the reproducibility test. In that case the deviations tend to be in the opposite direction; so that the net result of all the testing indicates that the values of spectral transmission tabulated on the charts should be a very close representation of what may be expected in the use of the filters. 


\section{COLORIMETRIC COMPUTATIONS}

The effect of the spectrophotometric uncertainties, the time and temperature deviations, etc., on the energy distribution of a source-andfilter combination ( $\mathrm{E}^{\prime \prime}$ on the charts) readily follows from the tables and curves already given in the sections devoted to these subjects. It is of importance also to consider the influence of these uncertainties and deviations on the color of the light transmitted by the filter.

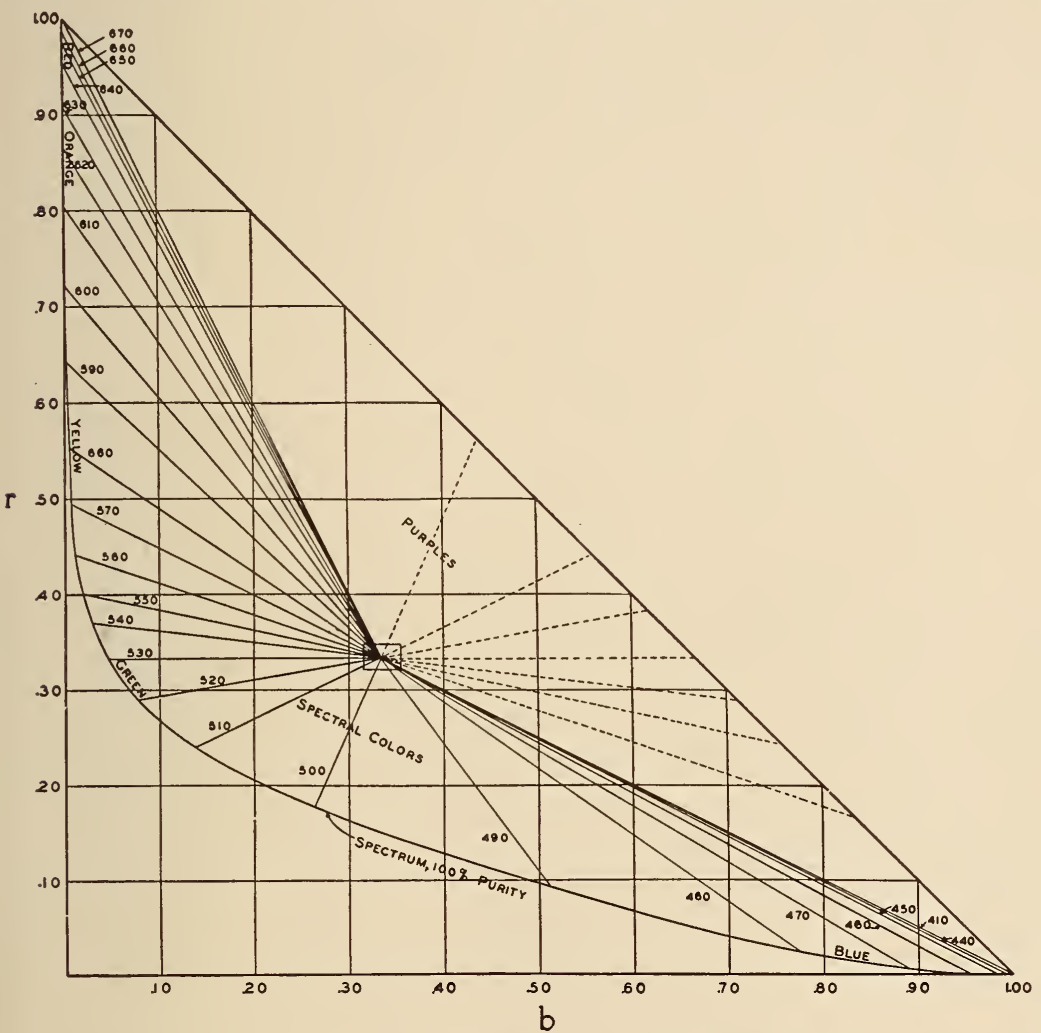

FIGURE 29.-The complete $r-b$ projection of the trilinear diagram showing the locus of spectrum colors

Mean sun is the "neutral" stimulus and is represented at the point $r=b=1 / 3$. Purples (colors whose stimuli are represented by white light minus homogeneous light of some wave length) are represented in the region bounded by the hy potenuse and the radial lines labeled " 410 " and " 670 ," which represent colors whose dominant wave lengths are found near the ends of the visible spectrum. Colors which may be evoked by a mixture of white light and homogeneous light are represented in the area bounded by the radial lines marked " 410 " and "670," and the curve marked "spectrum, 100 per cent purity."

The color of a light may be described in terms of the trilinear coordinates $(r, g, b)$, as outlined in Section V, 4, $(b)$. It will be recalled that the values of $r, g$, and $b$ sum to unity and that the color of mean sun has, by definition, a value of one-third for each coordinate. In Figure 29 is illustrated the $r-b$ diagram on which is also shown the location of the adopted mean sun $(r=b=1 / 3)$, the locus of the spectrum from the red to the violet, and the regions of the spectral colors and purples. 
As previously stated, all the filters of Series I, low color temperatures to mean sun, were adjusted to give an accurate color match with the adopted mean sun; that is, to have by computation values of $r=g=b=0.3333$. The uncertainties and deviations in which we are interested may, therefore, be illustrated by plotting the resulting $r$

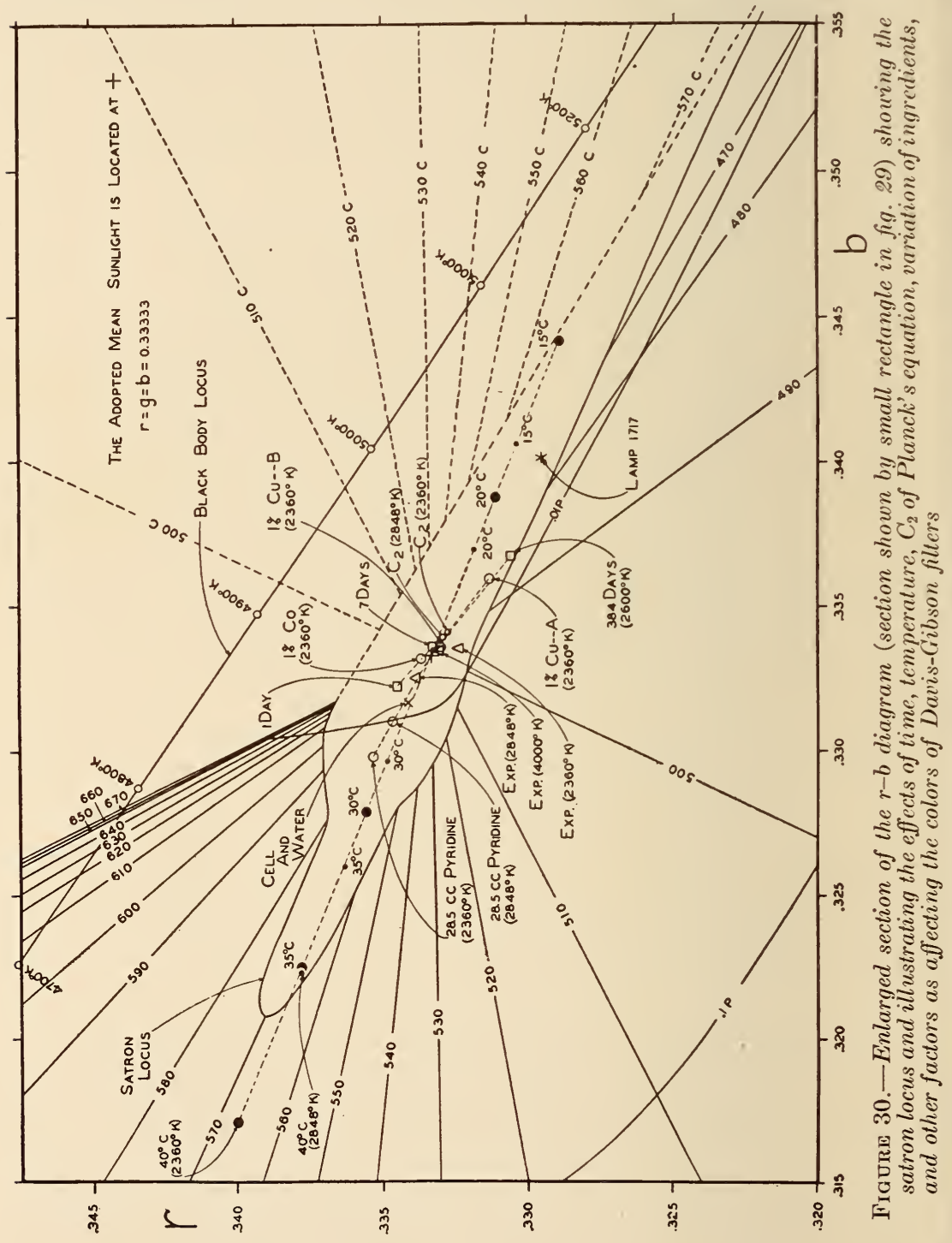

and $b$ values on the $r-b$ diagram. The differences from 0.3333 are so small, however, that they can not well be shown to the scale of Figure 29. The small rectangular section near the center of Figure 29 is therefore shown to a greatly enlarged scale in Figure 30.

A question which immediately arises is whether the various small differences illustrated in Figure 30 and discussed in detail in the fol- 
lowing sections are visually perceptible. No final answer to this can be given. Data on the "least perceptible difference" in color are very meager. Furthermore, this more or less vaguely defined quantity is so dependent upon the experimental conditions as to make any statement regarding it rather meaningless unless these experimental conditions are fully described.

One investigation has been carried out, however, which furnishes data of particular interest in this connection. This work was by Priest and Brickwedde on "The minimum perceptible colorimetric purity as a function of dominant wave length with sunlight as netural standard" (54). The complete paper has not yet been published. At each wave length they each made two determinations: (1) The least purity perceptible with certainty $\left(P_{\max }\right),(2)$ the greatest imperceptible purity $\left(P_{\min }\right)$.

In the present discussion we use a new unit of saturation derived from these data of Priest and Brickwedde and called the "satron." Since there is no previously published definition nor mention of this unit it is necessary to introduce some explanation of it. The idea of such a unit is predicated upon the concept of saturation as a psychological entity (4, p. 534) and the definition of purity as a ratio of brightnesses as defined by Priest (55, p. 175). Saturation is regarded as the minimum number of equally perceptible increments in purity between white and the color in question. The so-called just perceptible or least perceptible increment in purity is taken as the most convenient case of "equally perceptible." It is assumed that, for colors of very low saturation, and of constant dominant wave length, equal increments in purity are equally perceptible. It is, however, known (from the work of Priest and Brickwedde and others) that, for different wave lengths, equal increments in purity may be very far from being equally perceptible. It is indeed on this account that we find the data of Priest and Brickwedde particularly instructive in the discussion of the approximation to white which we now undertake. The term "satron" was tentatively proposed and defined by Priest in the spring of 1927 for the purpose of facilitating local disoussion relating to colors of low saturation among those concerned with this subject at the National Bureau of Standards. The definition written by Priest at that time is as follows:

For colors of low saturation $\left(\frac{P}{P^{\prime}}<20\right)$ one satron is the increment in saturation due to an increment in purity equal to $P^{\prime}{ }_{0}$, where $P^{\prime}{ }_{0}$, a function of dominant wave length, is taken as $\frac{P_{\max }+P_{\min }}{2}$ from the mean values of Priest and Brickwedde.

The effect of this definition is that a color having a saturation of one satron would be hardly distinguishable from white.

The locus of such colors on the $r-b$ diagram has been computed and plotted for us by D. B. Judd as shown in Figure 30. Colors whose trilinear coordinates locate points lying on this curve will be distinguished from white only by keen observers making careful observations-and even then usually with some doubt and hesitancy. Obviously, the colors corresponding to points lying within the area bounded by this curve will be distinguishable from white with still greater difficulty-and the more so the nearer they approach the center $(r=g=b=1 / 3)$. Roughly it may be said that the area bounded 
by this curve represents colors which may for most practical purposes be considered indistinguishable from white.

The experimental measurements on which its determination is based did not include the purples, so that the boundary on the purple side has been more or less arbitrarily estimated. It should be further noted that the white or "neutral" stimulus used in the experimental measurements was Abbot-Priest sunlight (Sec. II, 1), and that the present authors have assumed that the same relative values would have been obtained if the adopted mean sun had been used as the "neutral" stimulus. For the purposes of the present illustration this assumption is undoubtedly justified.

As already noted, the absolute values of the so-called least perceptible difference are subject to variations with experimental conditions, such as brightness, field size, observer, and observing technique. The relative values, and, therefore, the shape of the satron locus as shown in Figure 30, would probably, however, not be greatly affected, and it is a fortunate coincidence that the deviations to be considered are of such a nature as to lie more or less along the major rather than the minor axis of this region.

A record of the particular conditions under which Priest and Brickwedde made their observations has been published (54). Moreover, Priest has subsequently made other independent experiments which lead to the following previously unpublished conclusion which he has authorized us to quote:

For nearly white mixtures of Prussian blue with zinc oxide, comparing areas of about 3 or $4 \mathrm{~cm}^{2}$ in immediate juxtaposition in diffuse daylight, under ordinary conditions at a viewing distance of 30 to $40 \mathrm{~cm}$, it has been found, by fair tests on 16 observers, that a saturation of one satron is clearly recognized by the keenest observers, recognized with some doubt and hesitancy (but correctly) by the great majority, and is quite imperceptible only to a very small minority. The perceptibility appears to be of the same order as the perceptibility of a 1 per cent difference in brightness under the best photometric conditions.

\section{(a) SPECTROPHOTOMETRIC UNCERTAINTY}

Consider first the spectrophotometric discrepancies given in Table 26. It was of interest to compute the values of $r, g$, and $b$ that result if the experimental data are assumed to be wholly correct and the values given in Table 26 to be due entirely to error in the standard data. The values of $r, g$, and $b$ thus obtained are as follows: For the $2,360^{\circ} \mathrm{K}$. filter $r=0.33236, g=0.33407, b=0.33357$; for the $2,848^{\circ} \mathrm{K}$. filter, $r=0.33384, g=0.33360, b=0.33256$ (relative to Abbot-Priest sun as neutral); for the $4,000^{\circ} \mathrm{K}$. filter, $r=0.33305$, $g=0.33346, b=0.33349$. The results are shown in Figure 30 by the three points plotted as " $\operatorname{Exp}\left(2,360^{\circ} \mathrm{K}\right.$.)," "Exp $\left(2,848^{\circ} \mathrm{K}\right.$.)," and "Exp $\left(4,000^{\circ} \mathrm{K}\right.$.)." (The 2,848 $\mathrm{K}$. point is plotted as if Abbot-Priest sun were located at $r=b=0.3333$, since this filter was designed to give Abbot-Priest sun.)

If it be remembered that the standard values are, in fact, fully as reliable as the experimentally determined values (Sec. VIII, 1), it may be assumed that the spectrophotometric uncertainty in the standard data would cause deviations of not more than half those shown in Figure 30. 


\section{(b) DEVIATIONS FROM THEORETICAL CONCENTRATIONS}

In view of the small deviations of the actual content from the theoretical content which may occur in the copper and cobalt salts used in this investigation (Table 25) it is of considerable importance to know how such variations affect the color of the filters. For this purpose the trilinear coordinates were computed for the colors evoked by the $2,360^{\circ} \mathrm{K}$.-to-mean-sun filter-(1) for a 1 per cent increase in the copper content of solution A, keeping the concentrations of solution B unchanged, (2) for a 1 per cent increase in the copper content of solution $\mathrm{B}$, keeping solution $\mathrm{A}$ and the cobalt content of solution $\mathrm{B}$ unchanged, (3) for a 1 per cent increase in the cobalt content of solution $\mathrm{B}$, keeping the copper content of solutions A and B unchanged. Values of $r, g$, and $b$ were obtained in the three cases as follows:

(1) $r=0.33135, g=0.33267, b=0.33598$;

(2) $r=0.33301, g=0.33340, b=0.33360$;

(3) $r=0.33368, g=0.33311, b=0.33321$.

These values are plotted in Figure 30 , the " $1 \%$ " points. They indicate closely the directions of change caused by small variations of the concentrations in any of the filters. The magnitudes of such variations will be approximately proportional to the concentrations. For most of the filters (Tables 8 and 12) the concentrations are less than for the $2,360^{\circ} \mathrm{K}$.-to-mean-sun filter, and the deviations caused by a 1 per cent change in the copper and cobalt salts will be proportionately less.

It is obvious that small changes or uncertainties in the concentrations are of possible importance only in the case of the copper sulphate in solution A. Since the deviations from the theoretical copper content are rarely more than a fraction of a per cent, the results plotted in Figure 30 indicate that no perceptible differences in the color of the filters may be expected to result from uncertainties in the theoretical contents of the salts used.

\section{(c) DEVIATION FROM THEORETICAL PYRIDINE CONTENT}

It will be recalled that the pyridine used in deriving the standard absurbancy data of Table 4 had a strength of 98.4 per cent and that the total variation in the strengths of 17 samples of commercial pyridine examined in this investigation varied from 97.0 to 100.0 per cent or approximately $1 \frac{1 / 2}{2}$ per cent from the standard. In view of the questions that have been raised regarding the use of pyridine (41, 56) it is of special interest to compute the effect on the color of the filters caused by deviations of the pyridine strength from the standard. The effect of large deviations on the spectral absorbancy has been illustrated in Figures 8 and 24.

Values of $r, g$, and $b$ were computed for both the $2,360^{\circ}$ and $2,848^{\circ}$ K.-to-mean-sun filters with $28.5 \mathrm{cc}$ of pyridine instead of the usual $30.0 \mathrm{cc}$ and with the concentrations of the salts unchanged. Values were obtained as follows: For the $2,360^{\circ} \mathrm{K}$. filter, $r=0.33531$, $g=0.33484, b=0.32984$; for the $2,848^{\circ} \mathrm{K}$. filter, $r=0.33463, g=0.33431$ $b=0.33106$. The results are shown in Figure 30 by the points labeled "28.5 cc pyridine." It is apparent that the deviations caused by a given change in pyridine strength are approximately proportional to the copper concentration in solution A, these being 3.707 and $2.445 \mathrm{~g}$ respectively. It is also undoubtedly true that such deviations would 
be approximately proportional to the deviations in the pyridine strength.

It should be remembered that the results shown in Figure 30 are for a 5 per cent variation in pyridine strength, which is over three times as great a variation from the standard as was found in any of the 17 samples of pyridine examined. It may be shown from Figure 30 that the $1 \frac{1}{2}$ per cent variation from the standard, which is about the maximum to be expected in commercial pyridine, is of no greater importance colorimetrically than one-fourth of 1 per cent variation in the copper content of the A solution, or, conversely, that it would require more than a 6 per cent variation in pyridine strength to be colorimetrically equivalent to a 1 per cent variation in the copper content of solution A. (These values are derived as follows: The relative distances from the point $r=g=b=1 / 3$ to the points showing the 5 per cent variation in pyridine and the 1 per cent variation in the copper of the A solution are, respectively, in the proportion of 5.65:4.65. If the lines connecting these points and the point $r=g=b=1 / 3$ be extended to intersect the satron locus, we may estimate to what fraction of a satron these deviations are proportional. The values are $5.65 / 12.40=0.455$ for the pyridine, and $4.65 / 8.00=0.581$ for the copper. From this we find that 5 per cent variation in pyridine is $0.455 / 0.581=0.783$ as perceptible as 1 per cent variation in copper in the $\mathrm{A}$ solution, and that it, therefore, requires $5 / 0.783=6.4$ times as great a percentage change in the strength of pyridine to produce a perceptible color difference as is required in the copper sulphate in solution A.)

This illustration should end all opposition to the use of commercial pyridine arising from uncertainties regarding its strength. It may again be noted that the commercial pyridine obtainable in Great Britain has been found satisfactory for use in the filters. (See quotation at end of Section VII, 8.)

\section{(d) DEVIATION FROM STANDARD TEMPERATURE OF $25^{\circ} \mathrm{C}$.}

In Section VII, 4 are given data showing the change in absorbancy for each of the three component solutions as the temperature is raised from $25^{\circ}$ to $40^{\circ} \mathrm{C}$., it being further shown that this change in absorbancy is proportional to the concentration of the solution. On the basis of these data of Table 16 , the colors of the $2,360^{\circ}$ and $2,848^{\circ}$ K.-to-mean-sun filters, in combination with their respective sources, have been computed at $40^{\circ} \mathrm{C}$. and are plotted in Figure 30 . The values of $r, g$, and $b$ thus obtained are: For the $2,360^{\circ} \mathrm{K}$. filter, $r=0.33999, g=0.34286, b=0.31715$; for the $2,848^{\circ} \mathrm{K}$. filter, $r=0.33778$, $g=0.33986, b=0.32236$. Here again the deviations are approximately proportional to the copper concentration of solution A.

The values given at $35^{\circ}$ and $30^{\circ} \mathrm{C}$. are estimated by taking $2 / 3$ and $1 / 3$, respectively, of the distance along the straight line connecting the $25^{\circ} \mathrm{C}$. (standard white) point and the $40^{\circ} \mathrm{C}$. point; the values at $20^{\circ}$ and $15^{\circ} \mathrm{C}$. are likewise estimated by reversing the sign of the deviations shown at $30^{\circ}$ and $35^{\circ} \mathrm{C}$. No possible uncertainty in such estimations can be of any practical importance in this connection.

The importance of the temperature deviations shown in Figure 30 and the tolerance to be allowed will, of course, depend on the particular use being made of the filters. It would seem that a $\pm 5^{\circ} \mathrm{C}$. tolerance from the standard $25^{\circ} \mathrm{C}$. temperature would be perfectly safe in most 
colorimetric, photometric, and sensitometric work, and in many cases still larger tolerances could be permitted. It should be noted, however, that these solutions are powerful absorbers of radiant energy, due to the action of both the water and the copper sulphate, and the use of the filters in close proximity to lamps may be attended by relatively rapid increase in temperature of the solutions.

Since most of the temperature change is in the A solution, it is best to place the filter so that the A solution is on the side opposite the light source. A surer means of protection, where necessary, would be to place an auxiliary water cell between the filter and the source. A single or double water cell made with borosilicate crown glass windows, such as used in the filters, should have no perceptible effect on the color, as is illustrated in Figure 30, where the color of the double cell filled with water, computed from the standard spectral transmission data of Table 7, is shown by the point labeled "water cell." The effect of the water cell on the energy distribution is shown by its spectral transmission. In cases where two beams are being used, water cells may be placed in both beams, if considered desirable.

(e) CHANGE WITH TIME

It was shown in Section VII, 3 that the $B^{\prime}$ solution showed no certain change over a year's time, but that solution $\mathrm{A}^{\prime}$ showed small but definite changes as illustrated in Figure 21. A 2,600 K.-tomean-sun filter has concentrations close to those of the standard solutions, and it has accordingly been chosen for illustrating the aging effect. No tests have been made as to how this effect may vary with the concentration. In the computations under consideration the values shown in Figure 21 were multiplied by $3.024 / 3.000$, the ratio of the copper content of the $2,600^{\circ} \mathrm{K}$. A solution to that of the $\mathrm{A}^{\prime}$ solution.

The results are shown in Figure 30, the plotted values being labeled "1 day," "7 days," and "384 days." The trilinear coordinates for these three cases are: For 1 day, $r=0.33449, g=0.33322, b=0.33228$; for 7 days, $r=0.33328, g=0.33309, b=0.33362$; for 384 days, $r=0.33060, g=0.33266, b=0.33675$. Values for 24 days were not computed, as they would be practically identical with the standard values.

It is apparent that the color of any of the filters would not change perceptibly from a few days to several weeks, perhaps two or three months after preparation, but that solutions or filters a year or more old might be perceptibly different in color (but only so under the best colorimetric conditions) from newly prepared solutions or filters.

(f) CHANGE WITH $C_{2}$ IN PLANCK'S EQUATION

In Planck's equation (Sec. III, 3)

$$
E_{\lambda}=\frac{C_{1} \lambda^{-5}}{e^{\frac{C_{2}}{\lambda \theta}}-1}
$$

the relative values of $E_{\lambda}$ will obviously depend upon the value of $C_{2}$ (but not upon the value of $C_{1}$ ) which is used. It has been stated that a value of $C_{2}=14,350 \mu^{\circ}$, as used in B. S. Misc. Publication No. 
56 , enters into all the Planckian energy distributions of Table 2 as used throughout the present investigation. A value of 14,330 (1.433 $\mathrm{cm}^{\circ}$ ) has been used in the International Critical Tables. It was of interest to compute the effect on the color of the filters caused by this change in the value of $C_{2}$.

Values of $E_{\lambda}$ from 2,000 to $3,120^{\circ} \mathrm{K}$., based on values of $C_{2}=14,330$, have been recently published by Skogland (57), and values for $2,360^{\circ}$ and $2,848^{\circ} \mathrm{K}$. were taken from his tables and carried through in the regular computation for $r, g$, and $b$, in the case of the respective filters of Series I. The following values were obtained: For the $2,360^{\circ} \mathrm{K}$. filter, $r=0.33278, g=0.33309, b=0.33413$; for the $2,848^{\circ} \mathrm{K}$. filter, $r=0.33292, g=0.33312, b=0.33395$. These values are indicated in Figure 30 by the designations " $C_{2}\left(2,360^{\circ}\right)$ " and " $C_{2}\left(2,848^{\circ}\right)$."

It is more or less obvious, and has been pointed out in the appendix to M56, that differences in $C_{2}$ may be counterbalanced by differences in $\theta$. A change of 20 in $C_{2}$ is approximately equivalent to $3^{\circ} \mathrm{K}$. at $2,360^{\circ} \mathrm{K}$. and $4^{\circ} \mathrm{K}$. at $2,848^{\circ} \mathrm{K}$. To get the same respective energy distributions with $C_{2}=14,330$ as were obtained with $C_{2}=14,350$, values of $\theta$ equal to $2.357^{\circ}$ and $2,844^{\circ}-\mathrm{K}$. must be used.

If the filters of Series I had been designed with energy distributions derived on the basis of $C_{2}=14,330$ instead of 14,350, slightly lower concentrations of copper sulphate in the A solutions would have been necessary to secure perfect color match with the adopted mean sun. From the equivalents of $C_{2}$ given above and from Table 8 , it may be estimated that such perfect color match would have been obtained by using approximately $0.01 \mathrm{~g}$ less of copper sulphate than has been used in this series of filters. In the filters of Series II the change required would be even less, inasmuch as both the source and the ideal are computed from Planck's equation, and any change in $C_{2}$ affects both distributions in a similar manner.

It is apparent from Figure 30 that the error introduced by using $C_{2}=14,350$ instead of 14,330 (assuming that the latter is really correct) in the design of the filters is of the same order of magnitude as the spectrophotometric uncertainty in the data. It is probably less than is caused by the differences between the energy distributions as given by Planck's equation and as emitted by incandescent lamps. (Sec. III, 3.) It is much less than is caused by a $5^{\circ} \mathrm{C}$. deviation from the standard $25^{\circ} \mathrm{C}$. temperature. In fact, probably no case will arise in the use of the filters where the uncertainty in the value of $C_{2}$ will make the slightest practical difference.

\section{(g) EXPERIMENTALLY DETERMINED ENERGY}

It was shown in Section III, 3 (fig. 7) how the energy distribution of a particular Mazda C lamp as determined experimentally differed from the energy distribution as given by Planck's equation for the same color temperature $\left(2,848^{\circ} \mathrm{K}\right.$.). The effect on the color computed in the case of a $2,848^{\circ} \mathrm{K}$.-to-mean-sun filter, using the experimentally determined values as illustrated in Figure 7 instead of as given by Planck's equation for $2,848^{\circ} \mathrm{K}$., is shown in Figure 30 by the point plotted at "lamp 1717." The values of $r, g$, and $b$ obtained were, respectively, $0.32954,0.32935$, and 0.34111 . The shift toward the blue is caused by the excess of energy at the shorter wave lengths in the experimentally determined values. 
While it was of interest to compute the magnitude of the difference caused by the two energy distributions noted above, it is not believed that any such difference can be assumed in the case of incandescent tungsten lamps in general. In the first place, it is not felt that the experimentally determined values in the blue and violet can be entirely free from error caused by stray energy. Such stray energy from longer wave lengths in the visible and infra-red would undoubtedly cause an increasing percentage error toward the shorter wave lengths where the true spectral energy is relatively very low. Furthermore, it may be noted in this connection that Forsythe found (58) that "tungsten radiates in such a manner that when its temperature is set to give the same red-blue ratio as the black body for a particular temperature the green part of the tungsten spectrum is relatively brighter than that of the black body. This difference is, however, small, being less than one-half per cent at a color temperature of $1,600^{\circ} \mathrm{K}$. and increasing to about 1 per cent at a color temperature of $2,600^{\circ} \mathrm{K}$." The wave lengths of the red, green, and blue light used in these tests were about $660 \mathrm{~m} \mu, 540 \mathrm{~m} \mu$, and $470 \mathrm{~m} \mu$, respectively. It is believed that, if the same comparison were made in the case of the experimental energy distribution of Figure 7 and of a Planckian radiator at $2,848^{\circ} \mathrm{K}$., the experimental data would be low in the green relative to the red-blue values instead of high.

It would appear from the above evidence that the differences between the spectral energy distributions from a black body and from a tungsten lamp at the same color temperature are of no practical importance; and the reality of this small difference in the particular case illustrated in Figure 7 is subject to considerable question.

\section{EFFECT OF PYRIDINE CONTENT ON THE RESULTING ENERGY DISTRIBUTION}

In Section VII, 5 was illustrated the effect of the variation of the pyridine content on the spectral absorbancy of the A solution; and in Section VIII, $2(c)$ was illustrated the effect on the color of the source-and-filter combinations of small variations of pyridine content, such as might possibly occur as a result of the use of pyridine of subnormal strength. It remains to demonstrate the statements previously made that a pyridine content of approximately $30 \mathrm{cc}$ per liter, such as used in all the filters, gives the most suitable energy distribution which it is possible to obtain.

For this purpose two filters have been computed for converting $2,360^{\circ} \mathrm{K}$. to mean sun, following the methods described in Section $\mathrm{V}, 4(a)$ and Table 9, using in one case a pyridine content of 10 cc per liter and in the other a content of $100 \mathrm{cc}$ per liter, and in both cases adjusting the concentrations of all three components so as to obtain the best possible energy match with mean sun.

The results are illustrated in Figure 31, where the superiority of the 30 cc content is clearly apparent. The concentrations used are therein given. The effects are readily understandable if it be remembered (figs. 8 and 24) that increasing the pyridine content increases the absorbancy over most of the spectral range and also shifts the maximum absorbancy toward shorter wave lengths. At $10 \mathrm{cc}$ of pyridine the maximum absorbancy is too close to that of the copper sulphate $\left(\mathrm{B}_{1}\right)$, at $100 \mathrm{cc}$ it is too close to that of the cobalt $\left(\mathrm{B}_{2}\right)$. In 
both cases it is impossible to minimize the deviations from the ideal as satisfactorily as can be done with $30 \mathrm{cc}$ of pyridine, where the region of maximum absorbancy is properly spaced between those of the $\mathrm{B}_{1}$ and $\mathrm{B}_{2}$ components.

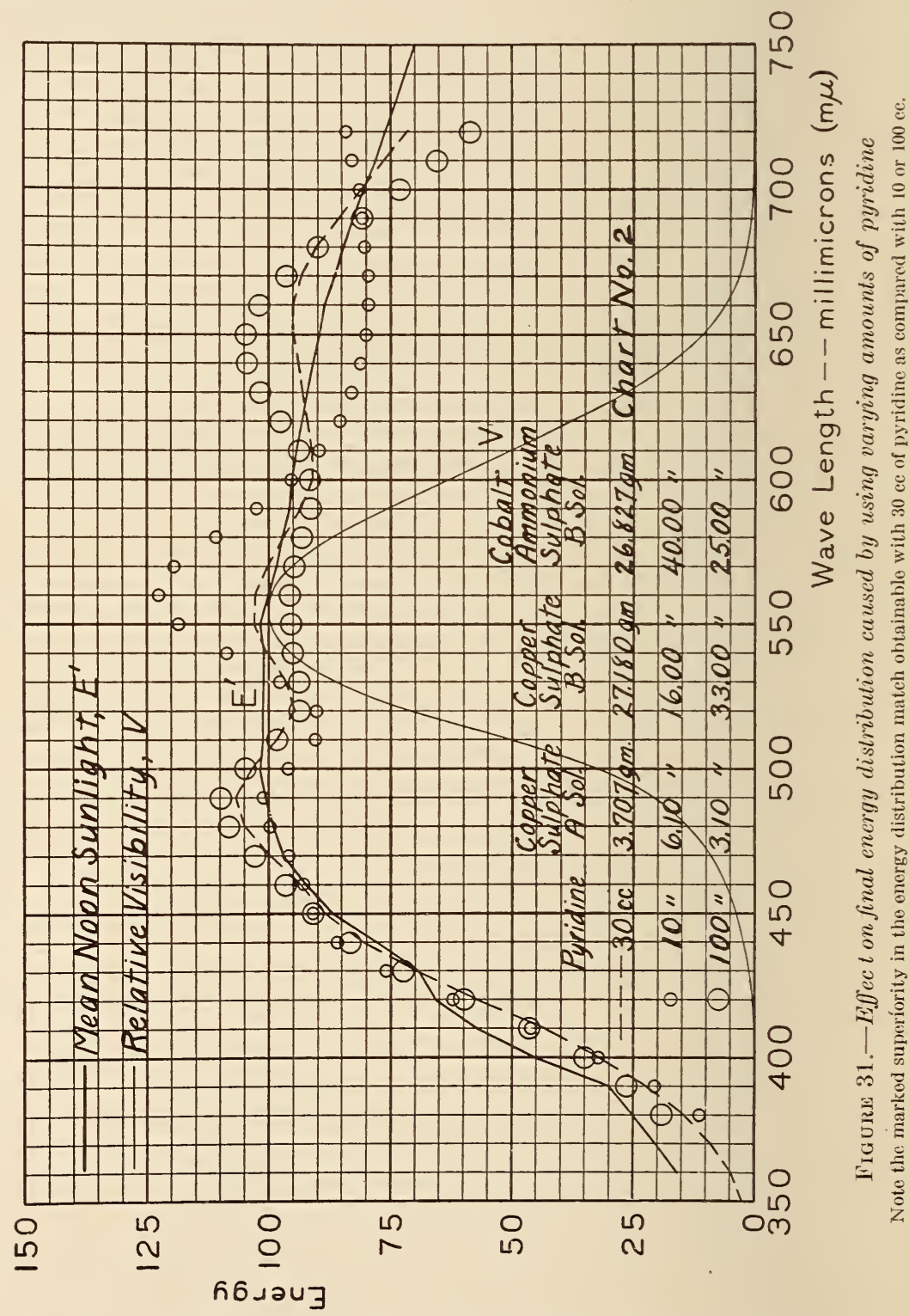

It is not claimed that slight improrement might not possibly still be made at some other pyridine content-for example, at 29 or $31 \mathrm{cc}$ per liter-but it is obvious that no such improvement would be of any practical importance. As a matter of fact, a content of $29 \mathrm{cc}$ was 
the exact value derived from the measurements and computations that were made at the time the value of $30 \mathrm{cc}$ was adopted.

\section{PRELIMINARY TESTS OF THE COLOR OF NOON SUNLIGHT AND DAYLIGHT AT WASHINGTON}

The measurements described werre undertaken both as a check on the color of certain of the filters and as a test of the applicability of the filters for precise colorimetric determinations of sunlight and davlight. The general methods possible for this purpose have been outlined in Section VI, 2 (b).

The tests under consideration were made in a south room, the window being raised during observations so that neither the skylight nor the sunlight passed through the glass of the window. A Martens photometer was placed about 2 feet from the window. For the overcast sky, the window was opened wide so that a considerable aperture of the southern sky was used. The horizon was screened off. For the noon-sun observations the window aperture was covered with cardboard except for a small opening which transmitted the sunlight beam to the photometer.

A standard lamp (B. S. 3256) was operated at $2,848^{\circ} \mathrm{K}$. This is the same lamp as that noted in the next section, and the $2,848^{\circ} \mathrm{K}$. point was checked before beginning the tests in September. The light from this lamp transmitted by the Davis-Gibson filter was incident on a white diffusing surface, light from which entered one field of the Martens photometer. Light from the sun or sky was diffused into the other field of the photometer by another surface of the same white material. The artificial light was incident on the diffusing white material at approximately the same angle as the natural light.

The brightnesses in the two fields of the photometer were always equated when the colors were being compared. In the September measurements the Loribond glasses necessary for exact color match were inserted in the sunlight or skylight beam; in the December measurements the glasses were inserted in the beam from the source and filter combination. The latter is a more accurate method, although in the method proposed in Section VI, 2 (b), where the light source is varied and only Lovibond red glasses of small denomination are necessary, the glass may be inserted in either beam as required with practically equal accuracy.

The results of this preliminary testing are shown in Figure 32. In addition to these experimental results, there are illustrated, in terms of the $r$ and $g$ coordinates used in plotting, the following data: (1) A portion of the black-body locus; (2) the sunlight locus as given by Abbot's 1917 data. Mean sun, lying on this locus, is taken as neutral, $r=g=b=1 / 3 ;$ (3) the sunlight locus as derived from Abbot's 1923 data; (4) Abbot-Priest sunlight; (5) the locus obtained by varying the color temperature of the source from $2,300^{\circ}$ to $3,000^{\circ} \mathrm{K}$. in the case of the filter designed to convert $2,848^{\circ} \mathrm{K}$. to sun outside atmosphere (1917 data), chart 32; and (6) the satron locus as determined by Priest and Brickwedde and reduced by Judd. (Sec. VIII, 2, and fig. 30.) In the illustration the irregular shaped figure surrounding the point representing the color of mean sunlight $(r=g=1 / 3)$ represents this locus. 
The experimental data plotted include (1) the individual observations on overcast southern sky in September, 1928; (2) the same for December, 1928; and (3) the means of the observations on direct sunlight from 11.30 to 12.30 on several days in December, 1928. The data on sunlight taken in September, 1928, are not plotted.

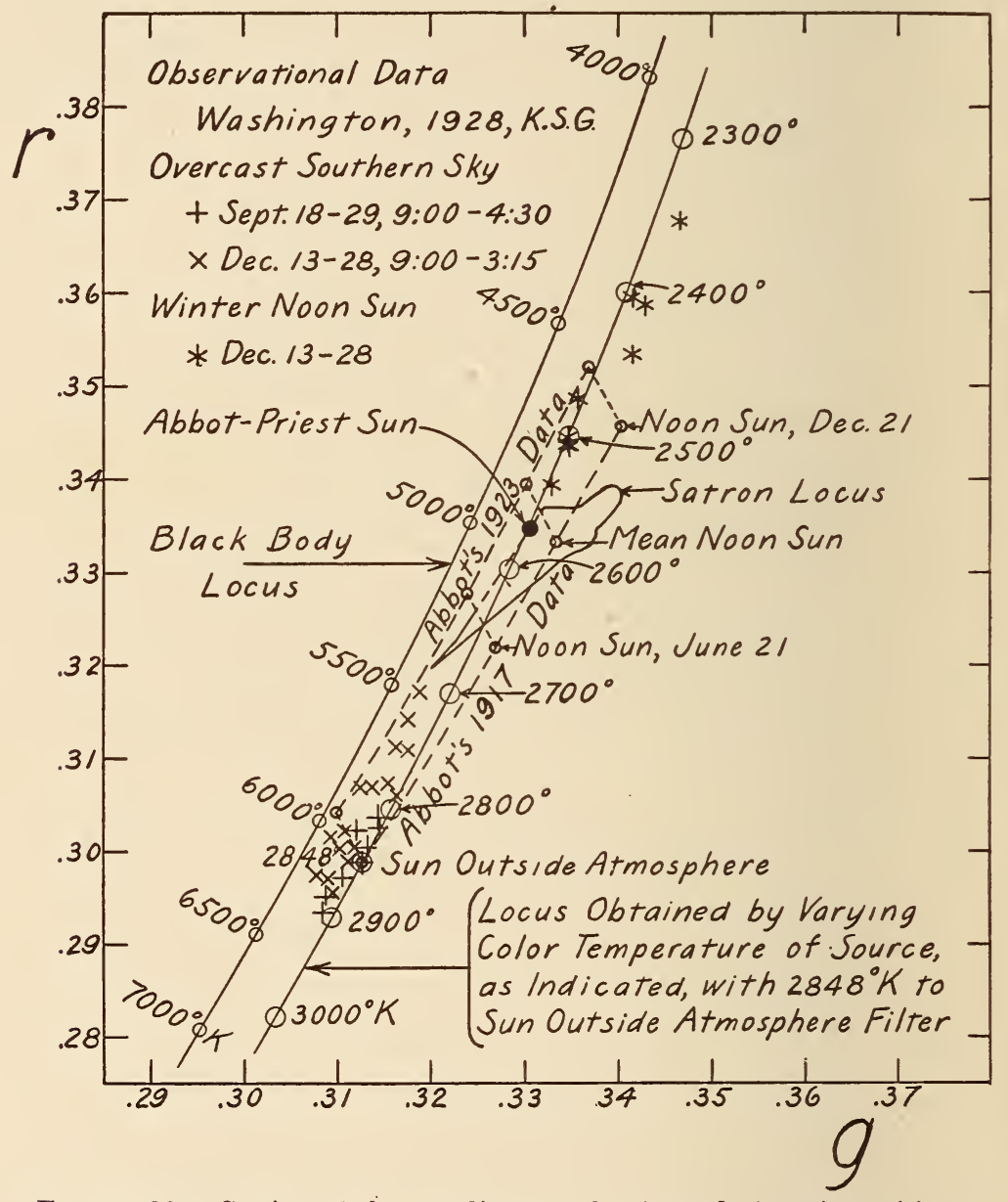

FIgURE 32.-Section of the $r$-g diagram showing colorimetric positions of winter noon sunlight and of overcast sky as experimentally observed by one of the authors, using certain of the filters and Lovibond glasses (see Sec. VIII, 4 for details)

The colorimetric positions of sunlight designated as Abbot's 1917 data were computed from the energy values of Table 1. The 1923 data for sunlight outside the earth's atmosphere were derived from Abbot's published data (Bib. ref., 42, Table 10, last column); the other 1923 data were derived by the authors as follows: By dividing the 1923 energy values for sun outside atmosphere by the corresponding 1917 values, wave length by wave length, correction factors were obtained which were applied to the other 1917 energy distributions to derive the corresponding 1923 distributions.

They were rendered questionable because of insufficient attention to a certain stray-light effect which was noticed at the start of the December measurements and thereupon eliminated. The results obtained, so far as this error can be estimated for the September 
sunlight measurements, would be consistent with the results shown in Figure 32. The error did not apply, at least to any important extent, to the data on overcast sky taken in September, 1928.

These data are presented more to illustrate the applicability of the filters for such measurements than as any important contribution toward the color of sunlight and daylight. Nevertheless, they are considered fairly reliable as far as they go. It is interesting to note that all the data obtained fall between the two sunlight loci as derived from Abbot's 1917 and 1923 data. The color temperature of practically all the data on overcast sky comes apparently between $6,000^{\circ}$ and $7,000^{\circ} \mathrm{K}$., confirming these figures as found by other observers. However, it may be noted that the colors observed are not exactly black-body colors, but are relatively slightly greenish. Inasmuch as Abbot's sun outside atmosphere (1923 data) is itself slightly green relative to the black body and since such true absorption as may take place in the atmosphere because of the water vapor would accentuate this greenness, it is believed the results obtained are exactly as to be expected.

The data on noon sunlight obtained in December, 1928, average nearer Abbot's 1923 data than the 1917 data, although lying between them. They tend to confirm Abbot-Priest sunlight as an excellent colorimetric representation of average noon sunlight, without con-

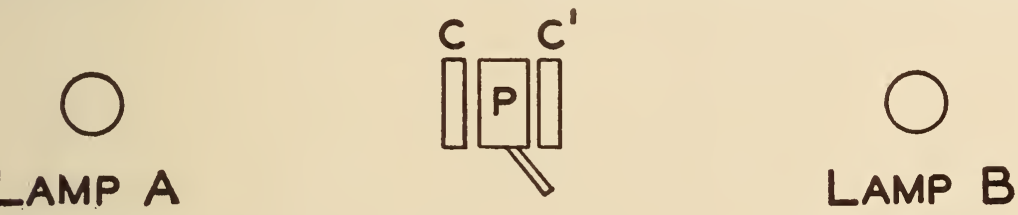

FIgure 33.-Schematic diagram showing photometer used to test the color match of the lamp-and-filter combinations

See text for explanation.

tradicting in any way the authors' contention that their adopted mean-sun energy distribution is a more suitable choice as a standard for photographic sensitometry than either $5,000^{\circ} \mathrm{K}$. or Abbot-Priest sun. The data further indicate the particular suitability of the second method proposed in Section VI, $2(b)$, for the study of daylight and noon sunlight, viz, the use of the filter for converting $2,848^{\circ} \mathrm{K}$. to sun outside atmosphere (1917 data), chart 32 , with a source calibrated for color temperature from $2,300^{\circ}$ to $3,000^{\circ} \mathrm{K}$. and Lovibond red glasses of low denomination (for example, maker's numerals 0.1, 0.2 , and 0.4 ).

\section{DETERMINATION OF COLOR TEMPERATURES OF INCANDESCENT LIGHTS}

The following test of the filters was made by R. P. Teele, of the photometry section. The quoted parts are from his report, B. S. 156 (e)-1-28, dated October 1, 1927 :

Lamp $A$ (fig. 33 ) is a 500 -watt gas-filled standard lamp, B.S. 3256 , belonging to the colorimetry section. It had been calibrated by Gibson in May, 1925, color temperature vs. applied voltage, over the range from $2,050^{\circ}$ to $2,900^{\circ} \mathrm{K}$.

Lamp $B$ is a 500 -watt 116 -volt floodlighting lamp.

The procedure followed was to have an observer vary the voltage of lamp $B$ to match the color of lamp $A$ at $2,360^{\circ} \mathrm{K}$. The distance of $A$ from $P$ was 
constant. The observer moved $B$ to get a brightness match as well as color match between $A$ and $B$. The voltage of $B$ was recorded.

The cell designated as $2,360^{\circ} \mathrm{K}$. to mean sun was then placed at $C^{\prime \prime}$ and the cell being observed placed at $C$. The cells placed at $C$ were $2,500^{\circ} \mathrm{K}$. to mean sun, $2,700^{\circ} \mathrm{K}$. to mean sun, and $2,848^{\circ} \mathrm{K}$. to mean sun. The lamp $A$ was then run at the desired temperature and the observer varied the voltage of $B$ to obtain a color match. The voltage of $B$ obtained with the cells in place and with the bare lamps should be the same if the cells are correct. $* * *_{*}$

From 6 to 8 observers took 2 observations each, both with and without the filters as described above, so that from 12 to 16 single observations went into the following averages:

\begin{tabular}{|c|c|c|c|c|c|c|}
\hline & No cells & $\begin{array}{l}2,500^{\circ} \mathrm{K} \text {. } \\
\text { cell at } C\end{array}$ & No cells & $\begin{array}{l}2, \pi 00^{\circ} \mathrm{K} \text {. } \\
\text { cell at } C\end{array}$ & No cells & $\begin{array}{l}2,848^{\circ} \mathrm{K} \text {. } \\
\text { cell at } C\end{array}$ \\
\hline $\begin{array}{l}\text { A verage voltage } \\
\text { A verage percentage deriation }\end{array}$ & $\begin{array}{r}71.28 \\
1.25\end{array}$ & $\begin{array}{r}71.2_{6} \\
1.9_{5}\end{array}$ & $\begin{array}{r}70.64 \\
1.24\end{array}$ & $\begin{array}{r}70.65 \\
1.58\end{array}$ & $\begin{array}{r}70.8_{4} \\
1.30\end{array}$ & $\begin{array}{r}70.8_{1} \\
1.17\end{array}$ \\
\hline
\end{tabular}

The "average percentage deriation" is an indication of the precision of the determinations, in one case at the color of $2,360^{\circ} \mathrm{K}$. and in the other at the color of mean sun. The final averages are 1.29 and 1.57 per cent, respectively, and the difference, if significant, may easily be accounted for by the fact that the determinations at the color of mean sun were made at a brightness level of only 17 to 26 per cent (the transmission of the respective filters at $C$ ) of those at the color of $2,360^{\circ} \mathrm{K}$.

It may or may not be significant that the arerage percentage deviation stays practically constant at the three trials with the $2,360^{\circ} \mathrm{K}$. color (no filters), while, with the mean-sun color, it consistently decreases as the field brightness increases. (The distance $A P$ being constant, the field brightness increases notably with increase in temperature of lamp $A$ for two reasons, viz: (1) Increase in the candlepower of $A$ and (2) increase in the transmission of the filter $C$.) This suggests that the rariation in precision may be due essentially to the variation in field brightness. Since, with lamp $A$ at $2,848^{\circ} \overline{\mathrm{K}}$. (relatively high brightness for the sunlight color), the arerage deviation is less than with the color match at $2,360^{\circ} \mathrm{K}$., one is led to suspect that the deviation with $\operatorname{lamp} A$ at lower temperatures would also have been less than with field color $2,360^{\circ} \mathrm{K}$. if the field brightness in these cases had been as high as with lamp $A$ at $2,848^{\circ} \mathrm{K}$. At any rate there would seem to be no loss of precision in determining the color temperatures of lamps by means of the filters of Series I.

So far as the accuracy of the filters for this purpose is concerned, the test is obriously satisfactory. The filters were prepared by Davis, using the same materials as used in deriving the standard data; but, as noted elsewhere, any deviations from the standard data caused by different chemicals would tend to cancel out in this use of the filters. The color matches were reported as perfect in all cases.

\section{TEST OF ACETYLENE-TO-MEAN-SUN FILTER}

A similar test was carried out using the filter designed to conrert the acetylene flame, as represented by Coblentz's energy data (Table 3 and Sec. V, $6(a))$, to mean sun. Quoting from the same report as before: 
The lamp $A$ (fig. 33) was replaced by an acetylene burner and the acetylene filter placed at $C$. The $2,360^{\circ}$ K.-to-mean-sun filter was placed at $C^{\prime}$ and the voltage of lamp $B$ varied for color match.

Eight observers took two readings each, so that 16 observations enter into the final average. A value of $71.3_{4}$ volts was obtained, compared with an average of $70.9_{2}$ obtained from the three previous measurements with the bare lamps and 70.91 with the filters. This difference is equivalent to about $5^{\circ}$ at $2,360^{\circ} \mathrm{K}$. The average "percentage deviation" was 2.18 , larger than obtained with the lamp and filters, and is readily accounted for by the fact that a perfect color match was not obtained with the acetylene and its filter. The conditions under which the acetylene was burned were as follows:

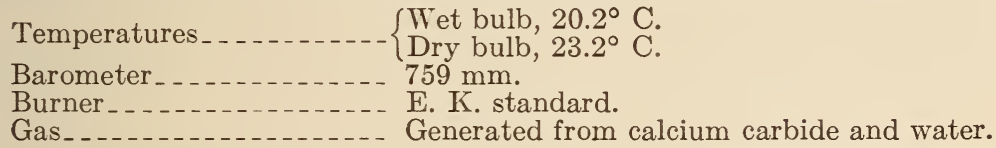

The pressure of the acetylene was $9 \mathrm{~cm}$ of water and was measured by an open manometer furnished with the burner.

Further examination of the filter by the authors, in the photometry section, confirmed the fact that the acetylene-and-filter combination did not give a perfect color match with mean sun as obtained with a standardized electric incandescent lamp operated at $2,360^{\circ} \mathrm{K}$. in combination with a $2,360^{\circ} \mathrm{K}$.-to-mean-sun filter. Removing the two filters showed a still larger difference in color. The acetylene was distinctly less saturated (whiter) in comparison. Next the current in the electric lamp was adjusted, without filters, in an attempt to obtain a color match. It was found, however, that a perfect color match between the acetylene light and the unfiltered electric light could not be obtained at any color temperature. The nearest approach to this was somewhat over $2,400^{\circ} \mathrm{K}$. During these experiments two Eastman Kodak acetylene burners, two calibrated electric lamps, and two sets each of acetylene-to-mean-sun and $2,360^{\circ} \mathrm{K}$.to-mean-sun filter solutions were used. The acetylene gas used in this experiment was made in the same way as described above.

The observations just described were not extensive enough to justify giving any new value for the color temperature of the acetylene flame as used with the standard Eastman Kodak burner, nor are they extensive enough to justify saying that a value of $2,360^{\circ} \mathrm{K}$. might never be obtained. Nevertheless, in view of the fact that Coblentz's energy data and the observations under consideration both give color temperatures definitely greater than $2,360^{\circ} \mathrm{K}$. (Sec. III, 4), it is felt that this value is rendered somewhat questionable, and that further careful measurement should be carried out. So far as these observations go they show that, if one wishes to calibrate an electric lamp for $2,360^{\circ} \mathrm{K}$. by means of the acetylene flame, a much more accurate value will be obtained when the filters are used than when not.

Presto-Lite acetylene was tried and found to be different from generated acetylene. The gas is absorbed by an earth impregnated with acetone in the Presto-Lite tanks. The chemistry division of the bureau has done considerable work on Presto-Lite, and finds that the acetone is carried over with the acetylene by an amount that varies from about 1.6 per cent when the tank is freshly charged to about 
3.0 per cent when the tank is nearly empty. It would seem inadvisable to use Presto-Lite for this type of work as the variation in acetone present changes the color of the flame. However, the Presto-Lite gas used gave a flame that within the uncertainties of the experiment corresponded to a color temperature of $2,360^{\circ} \mathrm{K}$.

\section{PREPARATION OF DAVIS-GIBSON FILTERS}

\section{SELECTION OF CHEMICALS}

In selecting chemicals to be used for preparing these filters care should be taken to obtain those of a quality at least equal to that known to the trade as "c. p." (chemically pure), from manufacturing chemists who can certify to their purity. A higher grade of chemicals known as "reagent" quality is recommended, as this would be some protection where no facilities exist for making chemical or spectrophotometric analysis of purchased materials.

Chemical analysis of the principal materials used in the design of these filters has already been given in Section IV, 2, and further noted in Section VII, 8. The following comments, however, may be of some assistance in detecting unsuitable chemicals:

1. Copper sulphate $\left(\mathrm{CuSO}_{4} \cdot 5 \mathrm{H}_{2} \mathrm{O}\right)$-Appearance.-Clean blue crystals of the pentahydrate free from white powder $\left(\mathrm{CuSO}_{4} \cdot 3 \mathrm{H}_{2} \mathrm{O}\right)$ or from any signs of moisture, such as small crystals (not the powder) adhering to the sides of the bottle. It should make a clear solution in water.

2. Cobalt ammonium sulphate $\left(\mathrm{CoSO}_{4}\left(\mathrm{NH}_{4}\right)_{2} \mathrm{SO}_{4} \cdot 6 \mathrm{H}_{2} \mathrm{O}\right)$. - Appearance.-Well-defined crystals, which should be free from any signs of moisture. It should make a clear solution in water.

If for any reason cobalt ammonium sulphate is not obtainable, cobalt sulphate $\left(\mathrm{CoSO}_{4} \cdot 7 \mathrm{H}_{2} \mathrm{O}\right)$ may be used (see, however, sections IV, $1(d)$, and IV, $1(e)$ ), provided the weights of cobalt ammonium sulphate specified are adjusted to give the same cobalt content. This may be obtained by multiplying the weights given on the charts by 0.7113 .

3. Mannite $\left(\mathrm{C}_{6} \mathrm{H}_{8}(\mathrm{OH})_{6}\right)$, d-mannitol.-Colorless needles which melt at $166^{\circ} \mathrm{C}$. (fine crystals, which, en masse, appear white).

4. Pyridine $\left(\mathrm{C}_{5} \mathrm{H}_{5} \mathrm{~N}\right)$. - A colorless liquid organic compound having a strong unpleasant odor. Specific gravity 0.979 at $25^{\circ} \mathrm{C}$., boiling point $115.5^{\circ} \mathrm{C}$. Should be practically colorless, and when added to water the solution should be clear.

5. Sulphuric acid $\left(\mathrm{H}_{2} \mathrm{SO}_{4}\right)$. - Should be clear and practically colorless. Specific gravity 1.84 .

\section{PREPARATION OF A AND B SOLUTIONS}

Solutions A and B are given to milligrams on the charts. This may appear to be an unwarranted refinement. However, we have attempted to design these filters so that the color in each case, as expressed in triliner coordinates, $r, g$, and $b$, would coincide with those of the ideal to four decimal places by computation. In Tables 8 and 12 , giving the concentrations of the ingredients for intermediate temperatures, the weights of cobalt ammonium sulphate and the copper sulphate in solution B are given to centigrams only, as this is sufficiently accurate for all practical purposes. The weights of copper 
sulphate in solution A are given to milligrams because $1 \mathrm{mg}$ in this case has even more significance than $10 \mathrm{mg}$ of the ingredients in solution $\mathrm{B}$.

1. Solution A.- Select several crystals of copper sulphate, enough for both $\mathrm{A}$ and $\mathrm{B}$ solutions, and crush in a mortar (not pulverize) until sufficiently fine to facilitate weighing. Weigh out in watch crystal the quantity required for solution $\mathrm{A}$, and dissolve in about one-half the total quantity of distilled water in a beaker. Use a wash bottle to get all of the weighed copper sulphate off the watch crystal into the solution. With the same weights, weigh out the mannite and add to the solution. After dissolving, add the pyridine and pour into a volumetric flask. Use the wash bottle to rinse out the beaker and add this rinse to the flask and make up the full volume with distilled water. Mix thoroughly and pour into a glass-stoppered bottle, which should be labeled and dated. Most chemicals contain a small quantity of minute insoluble material (trash) which will settle to the bottom of the bottle if left undisturbed for a few days. This solution should not be filtered. The clean solution can be removed with a pipette or by careful pouring if the bottle is nearly full. For work where the highest precision is desired this solution should be made up fresh every two or three months.

2. Solution B.-Follow the same procedure as given for solution A, adding the sulphuric acid after the copper sulphate and cobalt sulphate are dissolved. This solution apparently does not change with time. It is difficult to state just how long the B solution will keep. It is known to be good for over a year and probably is good for a much longer period of time.

\section{PREPARATION AND FILLING OF CELLS}

The cell illustrated in Figure 9 for holding the filter solutions consists of three plates of optical glass, borosilicate crown, ${ }^{19} 76 \mathrm{~mm}$ square by $2.5 \mathrm{~mm}$ thick, separated by two black glass ${ }^{20}$ frames, fine ground (not polished) to $10.00 \mathrm{~mm}$ thickness, with a central circular aperture for the solution $43 \mathrm{~mm}$ in diameter. A small hole, $5 \mathrm{~mm}$ in diameter, is cut from one side of the black glass frame to the central aperture. This hole is closed with a waxed cork or glass stopper and may be used in filling the cell.

The black glass separator frames when new should be thoroughly scrubbed with soap and water, using a brush, to remove particles of glass mud and abrasives with which the ground glass surfaces are usually impregnated; particular attention should be paid to cleaning the small hole through which the cell is filled. To avoid lint, the frames should be air dried without wiping with a cloth. The polished optical glass windows should be cleaned and wiped dry with a soft cloth or with lens tissue. When assembling the cell the parts should be carefully brushed (with a camel hair brush) to remove any dust particles and lint that may be adhering. In case the cell is to be filled without sealing the windows on with wax, it may be assembled wet and each compartment rinsed out with the filter solution several times before final filling.

${ }^{10}$ Borosilicate crown glass was chosen as the most suitable of the optical glasses. It has very high and almost nonselective transmission, and as previously noted, it is also the hardest of the optical glasses and probably the most resistant to chemical action.

20 Black glass is recommended because it prevents the passage of light through all portions of the cell other than the central aperture, thereby eliminating a mixture of filtered and unfiltered light in the apparatus in which it is used. 
The cell may be held together, as shown in Figure 9, with rubber bands or may be further sealed with paraffin or ceresin before filling. White ceresin is preferable to paraffin because of its higher melting point and hardness. The cell should be warmed ( $70^{\circ}$ to $80^{\circ} \mathrm{C}$.) and then placed (with rubber bands and stoppers in position) alternately on each edge in a pan of melted wax about $1 \mathrm{~cm}$ deep and allowed to remain long enough in each position for a film of the wax, by capillary action, to fill the seam up to the compartment for the filter solutions. If the cell is to be used only a short time (a few hours or even days) and the solution changed, it is advisable not to wax the edges as it will not leak if the small filling hole is tightly stoppered. In this case, the solution is easily removed and the cell washed out by separating the parts. If the windows are on very tight, as is usually the case after standing several days, the stoppers may be removed and reinserted. In this way the stopper serves as a pump forcing the solutions between the windows and the black glass frame. When wax is used to seal the cell it is, of course, necessary that the cell be warmed to take it apart. If a cell with larger aperture is desired, it is recommended that the outside dimension (not thickness) be also increased, because the cell is likely to leak if insufficient distance (surface area) between the outside and the central hole in the black glass is not maintained.

It should be remembered that the data given for the filters are based on a temperature of $25^{\circ} \mathrm{C}$. for the filter solutions. As noted before a tolerance of $\pm 5^{\circ} \mathrm{C}$. is permissible for most work (see Secs. VII, 4, VIII, 2, (d), VI, 1, (b), and VI, 2, (b)).

\section{CHARTS DESCRIBING FILTERS}

Charts 1 to 20, inclusive, contain the filter formulas and the spectra $]$ specifications of the mean-sun group of filters, referred to throughout the paper as Series I. Chart 2 is the $2,360^{\circ} \mathrm{K}$-to-mean-sun filter recommended for use in photographic sensitometry by the Serenth (1928) International Congress of Photography. The data on these charts are self-explanatory.

Charts 21 to 31, inclusive, Series II, comprise similar specifications for filters designed to convert the light from a $2,848^{\circ} \mathrm{K}$. source to color temperatures between the limits $3,500^{\circ}$ to $10,000^{\circ} \mathrm{K}$.

Several other filters not in the above series are given in charts 32 to 38 , inclusive, as listed in the accompanying index.

The weights of the ingredients and the light transmission for any intermediate filter, not given on the charts, may be found in Table 8 for the filters of Series I and in Table 12 for those of Series II. 


\section{Index to charts}

*1. $2,300^{\circ} \mathrm{K}$. to mean sunlight.

2. $2,360^{\circ} \mathrm{K}$. to mean sunlight.

*3. $2,400^{\circ} \mathrm{K}$. to mean sunlight.

4. $2,500^{\circ} \mathrm{K}$. to mean sunlight.

*5. $2,600^{\circ} \mathrm{K}$. to mean sunlight.

6. $2,700^{\circ} \mathrm{K}$. to mean sunlight.

*7. $2,800^{\circ} \mathrm{K}$. to mean sunlight.

8. $2,848^{\circ} \mathrm{K}$. to mean sunlight.

*9. $2,900^{\circ} \mathrm{K}$. to mean sunlight.

10. $3,000^{\circ} \mathrm{K}$. to mean sunlight.

*11. $3,100^{\circ} \mathrm{K}$. to mean sunlight.

12. $3,200^{\circ} \mathrm{K}$. to mean sunlight.

*13. $3,300^{\circ} \mathrm{K}$. to mean sunlight.

14. $3,400^{\circ} \mathrm{K}$. to mean sunlight.

$* 15$. $3,500^{\circ} \mathrm{K}$. to mean sunlight.

16. $3,600^{\circ} \mathrm{K}$. to mean sunlight.

*17. $3,700^{\circ} \mathrm{K}$. to mean sunlight.

18. $3,800^{\circ} \mathrm{K}$. to mean sunlight.

$* 19$. $3,900^{\circ} \mathrm{K}$. to mean sunlight.

20. $4,000^{\circ} \mathrm{K}$. to mean sunlight.

21. $2,848^{\circ} \mathrm{K}$. to $3,500^{\circ} \mathrm{K}$.
22. $2,848^{\circ} \mathrm{K}$. to $4,000^{\circ} \mathrm{K}$.

*23. $2,848^{\circ} \mathrm{K}$. to $4,500^{\circ} \mathrm{K}$.

24 . $2,848^{\circ} \mathrm{K}$. to $5,000^{\circ} \mathrm{K}$.

$* 25$. $2,848^{\circ} \mathrm{K}$. to $5,500^{\circ} \mathrm{K}$.

26. $2,848^{\circ} \mathrm{K}$. to $6,000^{\circ} \mathrm{K}$.

*27. $2,848^{\circ} \mathrm{K}$. to $6,500^{\circ} \mathrm{K}$.

28. $2,848^{\circ} \mathrm{K}$. to $7,000^{\circ} \mathrm{K}$.

29 . $2,848^{\circ} \mathrm{K}$. to $8,000^{\circ} \mathrm{K}$.

$30.2,848^{\circ} \mathrm{K}$. to $9,000^{\circ} \mathrm{K}$.

31. $2,848^{\circ} \mathrm{K}$. to $10,000^{\circ} \mathrm{K}$.

**32. $2,848^{\circ} \mathrm{K}$. to sunlight outside earth's atmosphere.

33. $2,848^{\circ} \mathrm{K}$. to Abbot-Priest sun.

34 . $2,848^{\circ} \mathrm{K}$. to summer noon sunlight.

35 . $2,848^{\circ} \mathrm{K}$. to winter noon sunlight.

36. Acetylene to mean sunlight.

$* * 37.2,450^{\circ} \mathrm{K}$. to $3,500^{\circ} \mathrm{K}$.

$* * 38.2,450^{\circ} \mathrm{K}$. to $6,500^{\circ} \mathrm{K}$.

* In order to save space these charts are nct published herein but any of them may be obtained from the authors on request.

$* *$ Colorimetric characteristics for these filters obtained by varying the color temperature of the source are described in Sections V, 6, $(d)$ and V, 6, $(e)$, Tables 13,14 and 15. 
$2360^{\circ} \mathrm{K}$ TO MEAN NOON SUNLIGHT AT WASHINGTON. CHART 2

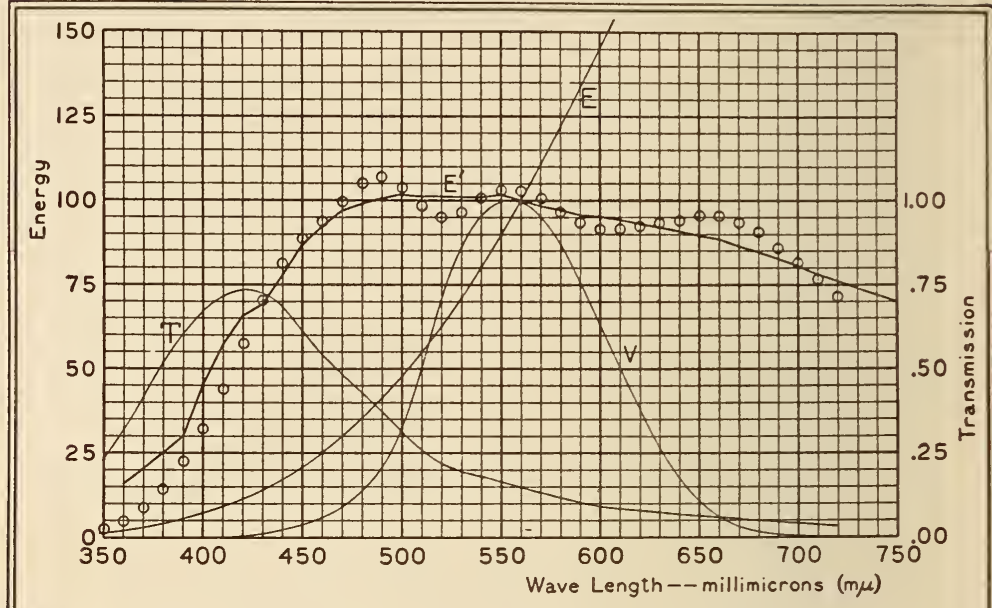

\begin{tabular}{|c|c|c|c|}
\hline$\underset{(m \mu)}{\lambda}$ & $\mathrm{T}$ & $E^{\prime \prime *}$ & $E^{\prime \prime} / E^{\prime}$ \\
\hline 350 & 0.230 & 2.5 & 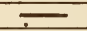 \\
\hline 60 & .321 & 4.9 & .304 \\
\hline 70 & .420 & 8.7 & .426 \\
\hline 80 & .518 & 14.5 & .579 \\
\hline 90 & .608 & 22.5 & .749 \\
\hline 400 & .671 & 32.3 & .715 \\
\hline 10 & .714 & 44.0 & .767 \\
\hline 20 & .737 & 57.4 & .871 \\
\hline 30 & .725 & 70.3 & 1.016 \\
\hline 40 & .682 & 81.2 & 1.044 \\
\hline 450 & .612 & 88.6 & 1.021 \\
\hline 60 & .540 & 93.9 & 1.018 \\
\hline 70 & .483 & 99.9 & 1.031 \\
\hline 80 & .431 & 105.0 & 1.060 \\
\hline 90 & .376 & 107.1 & 1.065 \\
\hline 500 & .315 & 103.9 & 1.020 \\
\hline 10 & .259 & 98.3 & .972 \\
\hline 20 & .219 & 95.0 & .939 \\
\hline 30 & .197 & 96.7 & .957 \\
\hline 40 & .182 & 100.6 & .997 \\
\hline 550 & .167 & 103.2 & 1.014 \\
\hline 60 & .1495 & 103.1 & 1.031 \\
\hline 70 & .1316 & 100.4 & 1.021 \\
\hline 80 & .1151 & 96.9 & .997 \\
\hline 90 & .1013 & 93.4 & .977 \\
\hline 600 & .0907 & 91.3 & .959 \\
\hline 10 & .0834 & 91.2 & .968 \\
\hline 20 & .0778 & 92.3 & .991 \\
\hline 30 & .0730 & 93.3 & 1.012 \\
\hline 40 & .0684 & 94.0 & 1.032 \\
\hline 650 & .0646 & 95.1 & 1.060 \\
\hline 60 & .0605 & 95.1 & 1.074 \\
\hline 70 & .0558 & 93.4 & 1.081 \\
\hline 80 & .0510 & 90.5 & 1.069 \\
\hline 90 & .0457 & 85.8 & 1.038 \\
\hline 700 & .0409 & 81.2 & 1.008 \\
\hline 10 & .0366 & 76.4 & .979 \\
\hline 20 & .0326 & 71.6 & .940 \\
\hline
\end{tabular}

T--Spectral Transmission of Filter at $25^{\circ} \mathrm{C}$

$V--$ Relative Visibility Function

E--Relative Energy of $2360^{\circ} \mathrm{K}$

$E^{\prime}--$ Relative Energy of Mean Noon Sunlight at Washington

$E^{\prime \prime}(=T \times E)^{*}--0000--$ Relative Energy of $2360^{\circ} \mathrm{K}$ and Filter Combination

Light Transmission of Filter for $2360^{\circ} \mathrm{K}=0.1352$

FILTER FORMULA

A $\begin{array}{lll}\text { Copper Sulphate }\left(\mathrm{CuSO}_{4} \cdot 5 \mathrm{H}_{2} \mathrm{O}\right) & 3.707 & \text { grams } \\ \text { Mannite }\left(\mathrm{C}_{6} \mathrm{H}_{0}(\mathrm{OH})_{6}\right) & 3.707 & \text { grams }\end{array}$ Pyridine $\left(\mathrm{C}_{5} \mathrm{H}_{5} \mathrm{~N}\right) \quad 30.0 \mathrm{cC}$ Water (distilled) to make 1000. cC

B

Cobalt Ammonium Sulphate

$\left(\mathrm{CoSO}_{4} \cdot\left(\mathrm{NH}_{4}\right)_{2} \mathrm{SO}_{4} \cdot 6 \mathrm{H}_{2} \mathrm{O}\right) \quad 26.827$ grams Copper Sulphate $\left(\mathrm{CuSO}_{4} \cdot 5 \mathrm{H}_{2} \mathrm{O}\right) \quad 27.180 \mathrm{grams}$ Sulphuric Acid (sp.gr. 1.835) $\quad 10.0 \quad$ ic Water (distilled) to make $1000 . \quad \mathrm{cc}$

These data are for a one centimeter layer each of solutions $A$ and $B$ in a double cell with three plates of borosilicate crown glass (refractive index, D line, $=1.51$ ), each $2.5 \mathrm{~mm}$ thick.

* Adjusted.to make sum of $E^{\prime \prime}-E^{\prime}$ from 400 to $720 \mathrm{~m} \mu$ equal practically to zero

* Factor to be used to multiply the candle-power of the light scurce to obtain the candle-power of the source-and-filter combination 


\section{$2500^{\circ} \mathrm{K}$ TO MEAN NOON SUNLIGHT AT WASHINGTON. CHART 4}

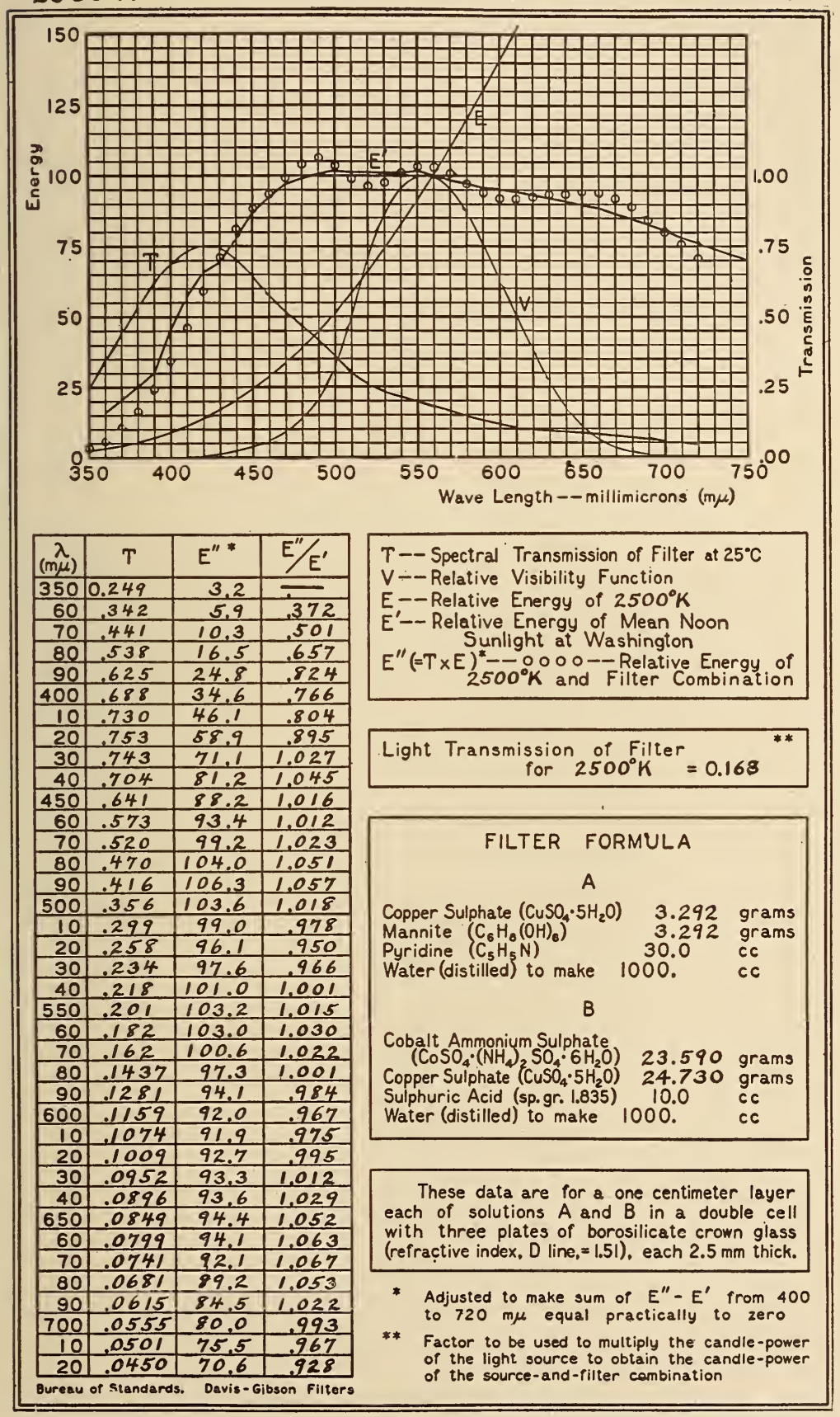

$13416^{\circ}-31-10$ 
$2700^{\circ} \mathrm{K}$ TO MEAN NOON SUNLIGHT AT WASHINGTON. CHART 6

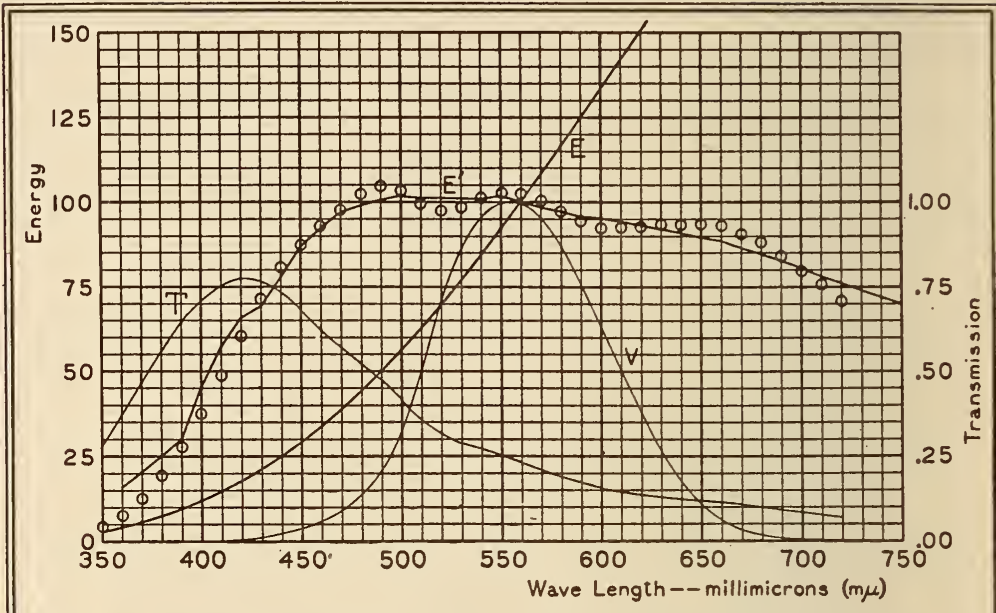

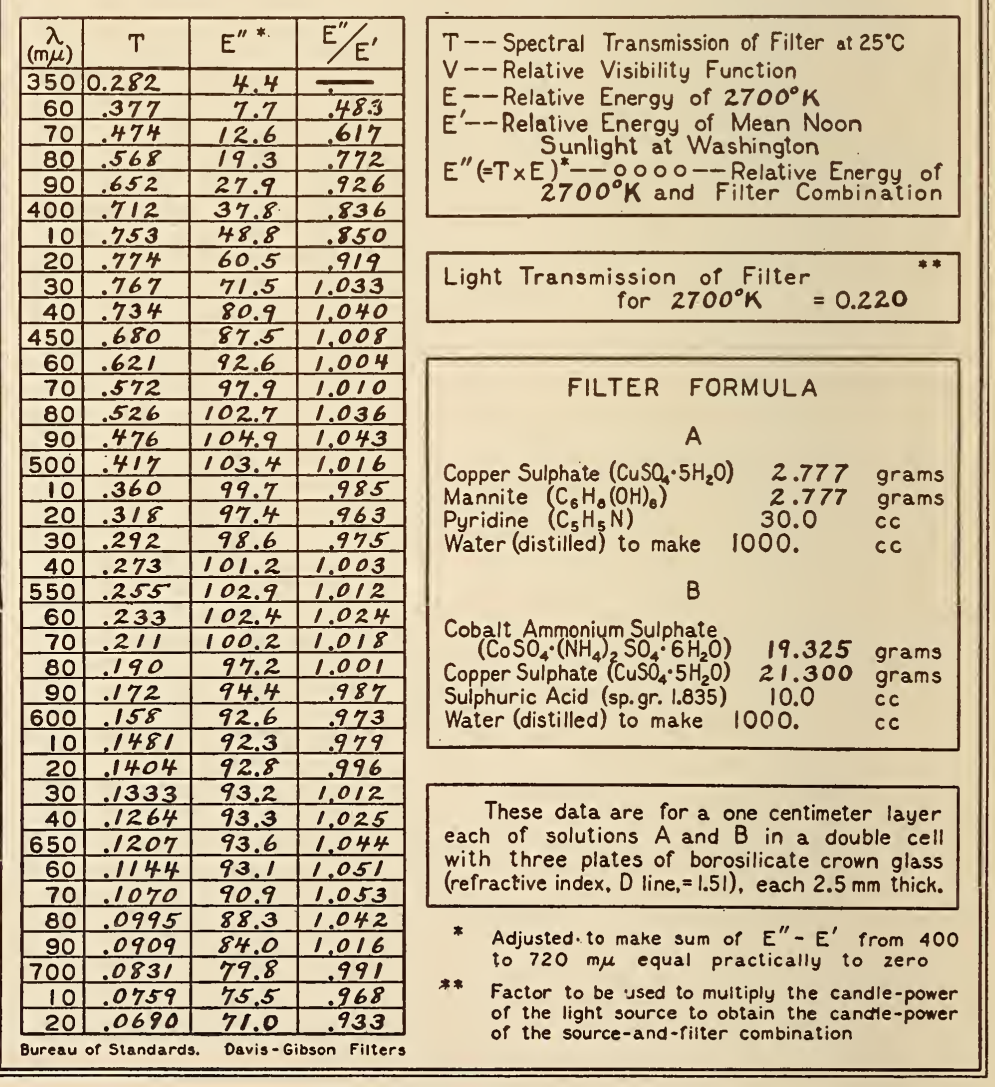


$2848^{\circ} \mathrm{K}$ TO MEAN NOON SUNLIGHT AT WASHINGTON.

CHART 8

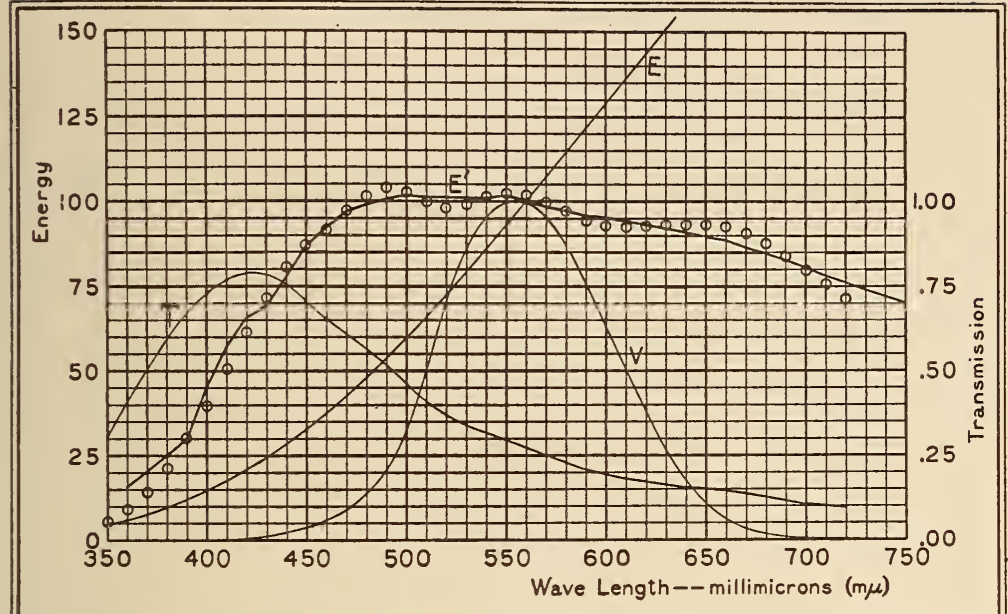

\begin{tabular}{|r|c|c|c|}
\hline$\lambda$ & $T$ & $E^{\prime \prime}$ & $E^{\prime \prime} / E^{\prime}$ \\
\hline$(m \mu)$ & 0.309 & 5.5 & $\overline{1}$ \\
\hline 350 & .404 & 9.2 & .579 \\
\hline 60 & .500 & 14.5 & .710 \\
\hline 70 & .501 & 21.5 & .858 \\
\hline 80 & .591 & 30.1 & 1.002 \\
\hline 90 & .671 & .00 \\
\hline 400 & .728 & 39.8 & .881 \\
\hline 10 & .768 & 50.4 & .880 \\
\hline 20 & .788 & 61.5 & .934 \\
\hline 30 & .783 & 71.8 & 1.037 \\
\hline 40 & .755 & 80.6 & 1.036 \\
\hline 450 & .707 & 87.0 & 1.001 \\
\hline 60 & .654 & 91.9 & .996 \\
\hline 70 & .609 & 97.1 & 1.001 \\
\hline 80 & .567 & 101.6 & 1.026 \\
\hline 90 & .519 & 104.0 & 1.034 \\
\hline 500 & .463 & 102.9 & 1.011 \\
\hline 10 & .407 & 100.0 & .988 \\
\hline 20 & .364 & 98.1 & .970 \\
\hline 30 & .337 & 99.2 & .982 \\
\hline 40 & .317 & 101.3 & 1.004 \\
\hline 550 & .297 & 102.5 & 1.008 \\
\hline 60 & .274 & 101.8 & 1.018 \\
\hline 70 & .250 & 99.8 & 1.014 \\
\hline 80 & .228 & 97.1 & .999 \\
\hline 90 & .209 & 94.6 & .989 \\
\hline 600 & .194 & 92.9 & .976 \\
\hline 10 & .183 & 92.6 & .982 \\
\hline 20 & .174 & 92.9 & .997 \\
\hline 30 & .166 & 93.1 & 1.011 \\
\hline 40 & .158 & 93.0 & 1.022 \\
\hline 650 & .152 & 93.2 & 1.039 \\
\hline 60 & .1446 & 92.5 & 1.045 \\
\hline 70 & .1362 & 90.5 & 1.048 \\
\hline 80 & .1274 & 87.8 & .037 \\
\hline 90 & .1175 & 83.9 & 1.015 \\
\hline 700 & .1084 & 79.9 & .991 \\
\hline 10 & .0998 & 75.8 & .972 \\
\hline 20 & .0915 & 71.5 & .940 \\
\hline 0 & 090 \\
\hline
\end{tabular}

$\mathrm{T}--$ Spectral Transmission of Filter at $25^{\circ} \mathrm{C}$

$\checkmark$--Relative Visibility Function

E--Relative Energy of $2848^{\circ} \mathrm{K}$

E'-- Relative Energy of Mean Noon

$E^{\prime \prime}(=T \times E)^{*}--00000--$ Relative Energy of $2848^{\circ} \mathrm{K}$ and Filter Combination

Light Transmission of Filter

for $2848^{\circ} \mathrm{K}=0.262$

FILTER FORMULA

A

Copper Sulphate $\left(\mathrm{CuSO}_{4} \cdot 5 \mathrm{H}_{2} \mathrm{O}\right) \quad 2.445$ grams Mannite $\left(\mathrm{C}_{6} \mathrm{H}_{8}(\mathrm{OH})_{8}\right)^{2} \quad 2.445$ grams Pyridine $\left(\mathrm{C}_{5} \mathrm{H}_{5} \mathrm{~N}\right) \quad 30.0 \mathrm{cC}$ Water (distilled) to make $1000 . \quad \mathrm{CC}$

\section{B}

Cobalt Ammonium Sulphate

$\left(\mathrm{CoSO}_{4} \cdot\left(\mathrm{NH}_{4}\right)_{2} \mathrm{SO}_{4} \cdot 6 \mathrm{H}_{2} \mathrm{O}\right) \quad 16.520$ grams Copper Sulphate (CuSO $\left.4 \mathrm{H}_{2} \mathrm{O}\right) \quad 19.020$ grams $\begin{array}{llll}\text { Sulphuric Acid (sp.gr. 1.835) } & 10.0 \quad \text { cc }\end{array}$ Water (distilled) to make 1000. cc

These data are for a one centimeter layer each of solutions $A$ and $B$ in a double cell with three plates of borosilicate crown glass (refractive index, D line, $=1.51$ ), each $2.5 \mathrm{~mm}$ thick.

* Adjusted to make sum of $E^{\prime \prime}-E^{\prime}$ from 400 to $720 \mathrm{~m} \mu$ equal practically to zero

* Factor to be used to multiply the candle-power of the light source to obtain the candle-power of the source-and-filter combination 
$3000^{\circ} \mathrm{K}$ TO MEAN NOON SUNLIGHT AT WASHINGTON.

CHART 10

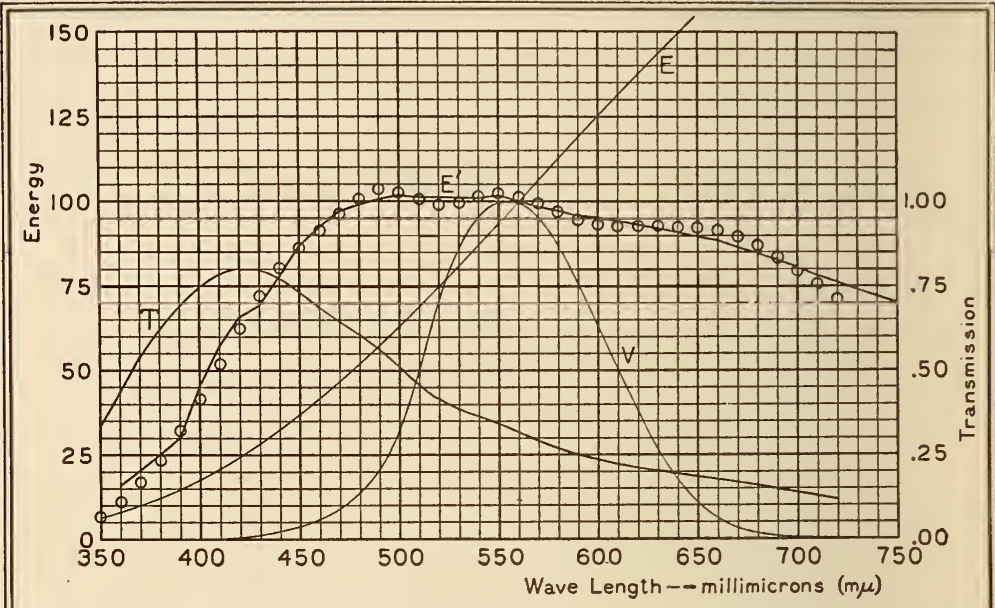

\begin{tabular}{|c|c|c|c|}
\hline$\underset{(m \mu)}{\lambda}$ & $\mathrm{T}$ & $E^{\prime \prime *}$ & $E^{\prime \prime} / E^{\prime}$ \\
\hline 350 & 0.340 & 6.7 & \\
\hline 60 & .434 & 11.0 & .696 \\
\hline 70 & .528 & 16.6 & .812 \\
\hline 80 & .615 & 23.8 & .951 \\
\hline 90 & .691 & 32.5 & 1.079 \\
\hline 400 & .745 & 41.9 & .928 \\
\hline 10 & .782 & 520 & .908 \\
\hline 20 & .802 & 62.4 & .948 \\
\hline 30 & .798 & 72.1 & 1.041 \\
\hline 40 & .774 & 80.3 & 1.032 \\
\hline 450 & .733 & 86.4 & .995 \\
\hline 60 & .686 & 91.4 & .991 \\
\hline 70 & .647 & 96.5 & .995 \\
\hline 80 & .607 & 100.8 & 1.018 \\
\hline 90 & .563 & 103.3 & 1.027 \\
\hline 500 & .510 & 102.7 & 1.010 \\
\hline 10 & .456 & 100.5 & .993 \\
\hline 20 & .414 & 99.0 & .978 \\
\hline 30 & .386 & 99.8 & .988 \\
\hline 40 & .364 & 101.5 & 1.006 \\
\hline 550 & .343 & 102.3 & 1.006 \\
\hline 60 & .318 & 101.5 & 1.015 \\
\hline 70 & .294 & 99.5 & 1.011 \\
\hline 80 & .270 & 97.1 & .999 \\
\hline 90 & 250 & 94.8 & .991 \\
\hline 600 & 233 & 93.2 & .980 \\
\hline 10 & .222 & 92.9 & .986 \\
\hline 20 & .212 & 93.0 & .998 \\
\hline 30 & .203 & 93.0 & 1.009 \\
\hline 40 & .195 & 92.7 & 1.019 \\
\hline 650 & .188 & 92.6 & 1.033 \\
\hline 60 & .179 & 91.7 & 1.036 \\
\hline 70 & .170 & 89.8 & 1.039 \\
\hline 80 & .160 & 87.2 & 1.029 \\
\hline 90 & 1484 & 83.4 & 1.008 \\
\hline 700 & .1378 & 79.6 & .989 \\
\hline 10 & 1279 & 75.7 & .970 \\
\hline 20 & .1180 & 71.5 & .940 \\
\hline
\end{tabular}

$\mathrm{T}--$ Spectral Transmission of Filter at $25^{\circ} \mathrm{C}$

V-- Relative Visibility Function

E--Relative Energy of $3000^{\circ} \mathrm{K}$

$E^{\prime}-$ Relative Energy of Mean Noon Sunlight at Washington

$E^{\prime \prime}(=T \times E)^{*}--0000--$ Relative Energy of $3000^{\circ} \mathrm{K}$ and Filter Combination

$\begin{gathered}\text { Light Transmission of Filter } \\ \text { for } 3000^{\circ} \mathrm{K}\end{gathered}=0.307^{* *}$

FILTER FORMULA

A

Copper Sulphate $\left(\mathrm{CuSO}_{4} \cdot 5 \mathrm{H}_{2} \mathrm{O}\right) \quad 2.140$ grams Mannite $\left(\mathrm{C}_{6} \mathrm{H}_{8}(\mathrm{OH})_{6}\right) \quad 2.140$ grams Pyridine $\left(\mathrm{C}_{5} \mathrm{H}_{5} \mathrm{~N}\right) \quad 30.0 \mathrm{CC}$ Water (distilled) to make 1000 . CC

\section{B}

Cobalt Ammonium Sulphate

$\left(\mathrm{CoSO}_{4} \cdot\left(\mathrm{NH}_{4}\right)_{2} \mathrm{SO}_{4} \cdot 6 \mathrm{H}_{2} \mathrm{O}\right) \quad 13.900$ grams Copper Sulphate $\left(\mathrm{CuSO}_{4} \cdot 5 \mathrm{H}_{2} \mathrm{O}\right) \quad 17.000$ grams Sulphuric Acid (sp.gr. 1.835) $10.0 \quad \mathrm{cc}$ Water (distilled) to make $1000 . \quad$ cC

These data are for a one centimeter layer each of solutions $A$ and $B$ in a double cell with three plates of borosilicate crown glass (refractive index. D line, =1.5I), each $2.5 \mathrm{~mm}$ thick.

* Adjusted to make sum of $E^{\prime \prime}-E^{\prime}$ from 400 to $720 \mathrm{~m} \mu$ equal practically to zero

* Factor to be used to multiply the candle-power of the light source to obtain the candle-power of the source-and-filter combination 
$3200^{\circ} \mathrm{K}$ TO MEAN NOON SUNLIGHT AT WASHINGTON.

CHART 12

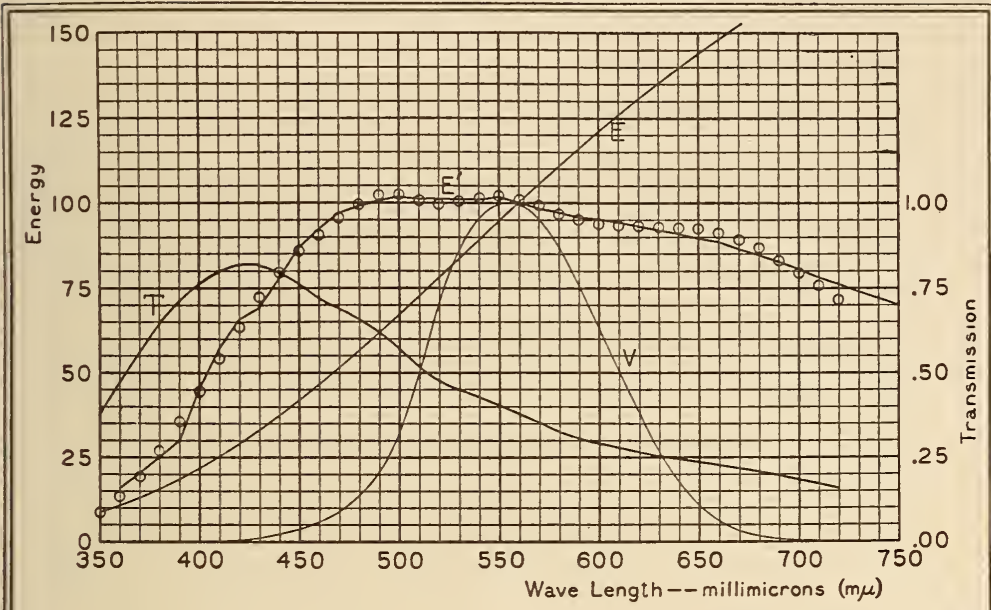

\begin{tabular}{|c|c|c|c|}
\hline $\begin{array}{c}\lambda \\
(\mathrm{m} \mu)\end{array}$ & $T$ & $E^{\prime \prime}$ & $E^{\prime \prime} / E^{\prime}$ \\
\hline 350 & 0.382 & 8.7 & \\
\hline 60 & .475 & 13.5 & .844 \\
\hline 70 & .565 & 19.6 & .956 \\
\hline 80 & .647 & 27.0 & 1.077 \\
\hline 90 & .716 & 35.5 & 1.180 \\
\hline 400 & .766 & 44.6 & .988 \\
\hline 10 & .800 & 54.1 & .944 \\
\hline 20 & .818 & 63.6 & .966 \\
\hline 30 & .816 & 72.4 & 1.046 \\
\hline 40 & .798 & 79.9 & 1.027 \\
\hline 450 & .765 & 85.9 & .989 \\
\hline 60 & .726 & 90.7 & .983 \\
\hline 70 & .692 & 95.4 & .984 \\
\hline 80 & .658 & 99.6 & 1.006 \\
\hline 90 & .618 & 102.3 & 1.018 \\
\hline 500 & .570 & 102.4 & 1.006 \\
\hline 10 & .521 & 100.9 & .998 \\
\hline 20 & .479 & 99.8 & .986 \\
\hline 30 & .451 & 100.4 & .994 \\
\hline 40 & .428 & 101.5 & 1.006 \\
\hline 550 & .405 & 101.9 & 1.002 \\
\hline 60 & .379 & 101.0 & 1.010 \\
\hline 70 & .354 & 99.1 & 1.008 \\
\hline 80 & .329 & 97.0 & .998 \\
\hline 90 & .308 & 95.0 & .993 \\
\hline 600 & .291 & 93.6 & .984 \\
\hline 10 & .278 & 93.2 & .988 \\
\hline 20 & .268 & 93.2 & 1.000 \\
\hline 30 & .258 & 92.9 & 1.008 \\
\hline 40 & .249 & 92.6 & 1.017 \\
\hline 650 & .240 & 92.2 & 1.028 \\
\hline 60 & .231 & 91.1 & 1.029 \\
\hline 70 & .220 & 89.1 & 1.032 \\
\hline 80 & .209 & 86.7 & 1.023 \\
\hline 90 & .196 & 83.0 & 1.004 \\
\hline 700 & .183 & 79.5 & .987 \\
\hline 10 & .172 & 75.8 & .972 \\
\hline 20 & .160 & 71.8 & .944 \\
\hline
\end{tabular}

$\mathrm{T}--$ Spectral Transmission of Filter at $25^{\circ} \mathrm{C}$

$V--$ Relative Visibility Function

E--Relative Energy of $3200^{\circ} \mathrm{K}$

$E^{\prime}--$ Relative Energy of Mean Noon Sunlight at Washington

$E^{\prime \prime}(=T \times E)^{*}--\circ \circ \circ \circ--$ Relative Energy of $3200^{\circ} \mathrm{K}$ and Filter Combination

Light Transmission of Filter $0.370^{* *}$ for $3200^{\circ} \mathrm{K}=0.370$

\section{FILTER FORMULA}

A

Copper Sulphate $\left(\mathrm{CuSO}_{4} \cdot 5 \mathrm{H}_{2} \mathrm{O}\right) \quad 1.784$ grams Mannite $\left(\mathrm{C}_{6} \mathrm{H}_{8}(\mathrm{OH})_{6}\right) \quad 1.784$ grams Pyridine $\left(\mathrm{C}_{5} \mathrm{H}_{5} \mathrm{~N}\right) \quad 30.0 \mathrm{cC}$ Water (distilled) to make $1000 . \quad \mathrm{CC}$

\section{B}

Cobalt Ammonium Sulphate

$\left(\mathrm{CoSO}_{4} \cdot\left(\mathrm{NH}_{4}\right)_{2} \mathrm{SO}_{4} \cdot 6 \mathrm{H}_{2} \mathrm{O}\right) \quad 10.890$ grams Copper Sulphate $\left(\mathrm{CuSO}_{4} \cdot 5 \mathrm{H}_{2} \mathrm{O}\right) \quad 14.570$ grams Sulphuric Acid (sp.gr. 1.835) $\quad 10.0 \quad \mathrm{cc}$ Water (distilled) to make $1000 . \quad$ cc

These data are for a one centimeter layer each of solutions $A$ and $B$ in a double cell with three plates of borosilicate crown glass (refractive index, D line, $=1.51$ ), each $2.5 \mathrm{~mm}$ thick.

* Adjusted. to make sum of $E^{\prime \prime}-E^{\prime}$ from 400 to $720 \mathrm{~m} \mu$ equal practically to zero

* Factor to be used to multiply the candle-power of the light source to obtain the candle-power of the source-and-filter combination 
$3400^{\circ} \mathrm{K}$ TO MEAN NOON SUNLIGHT AT WASHINGTON.

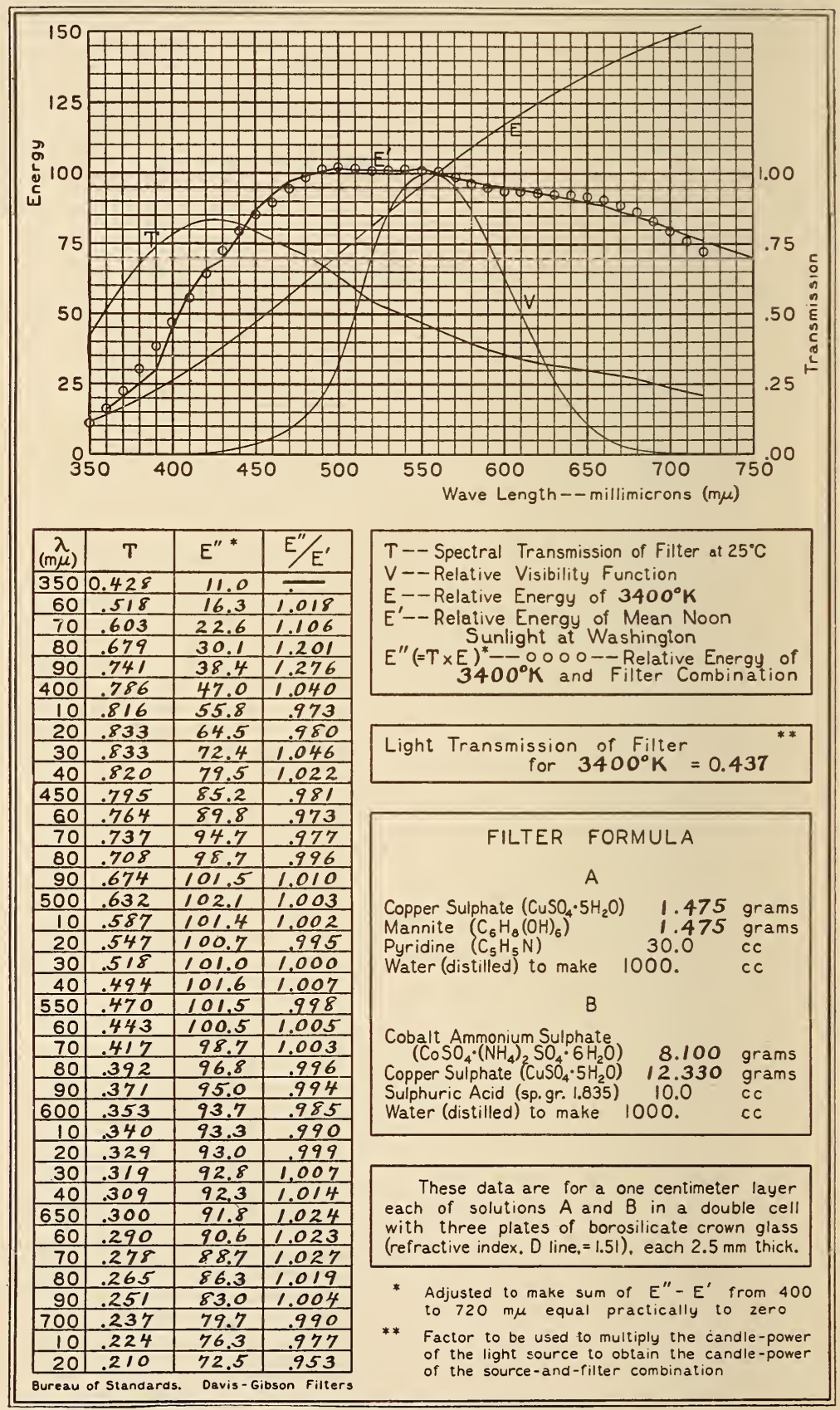


$3600^{\circ} \mathrm{K}$ TO MEAN NOON SUNLIGHT AT WASHINGTON. CHART 16

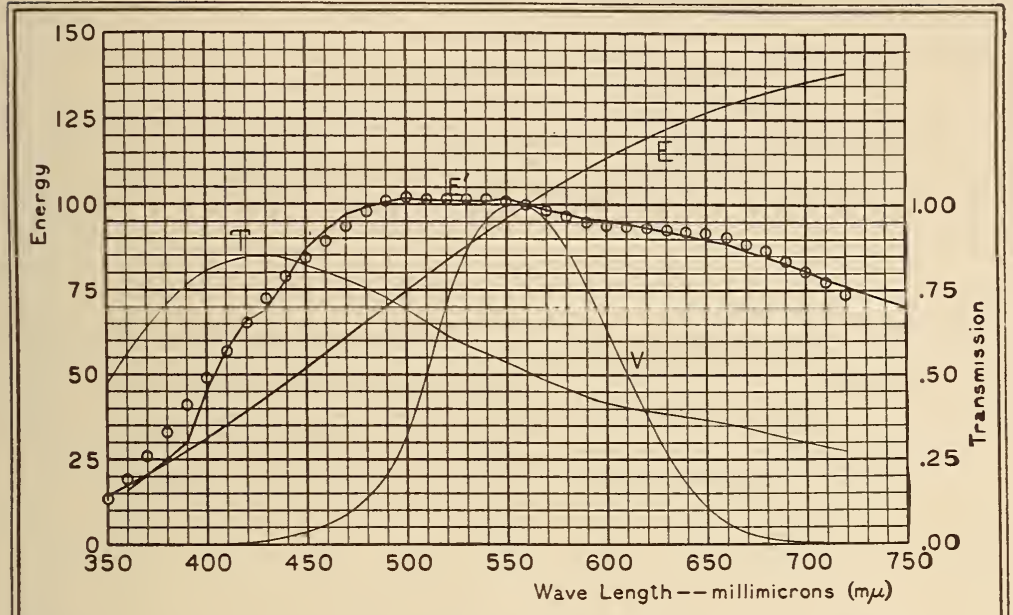

\begin{tabular}{|c|c|c|c|}
\hline$\underset{(m \mu)}{\lambda}$ & $T$ & $E^{\prime \prime *}$ & $E^{\prime \prime} / E^{\prime}$ \\
\hline 350 & 0.476 & 13.7 & \\
\hline 60 & .563 & 19.2 & 1.205 \\
\hline 70 & .642 & 25.8 & 1.262 \\
\hline 80 & .710 & 33.2 & 1.323 \\
\hline 90 & .765 & 41.2 & 1.368 \\
\hline 400 & .805 & 49.2 & 1.089 \\
\hline 10 & .832 & 57.2 & .998 \\
\hline 20 & .847 & 65.1 & .989 \\
\hline 30 & .849 & 72.4 & 1.047 \\
\hline 40 & .841 & 78.9 & 1.014 \\
\hline 450 & .823 & 84.4 & .972 \\
\hline 60 & .800 & 89.2 & .967 \\
\hline 70 & .779 & 93.7 & .967 \\
\hline 80 & .756 & 97.7 & .987 \\
\hline 90 & .728 & 100.7 & 1.001 \\
\hline 500 & .693 & 101.9 & 1.001 \\
\hline 10 & .654 & 101.7 & 1.005 \\
\hline 20 & .617 & 101.3 & 1.001 \\
\hline 30 & .588 & 101.5 & 1.004 \\
\hline 40 & .562 & 101.6 & 1.007 \\
\hline 550 & .536 & 101.1 & .994 \\
\hline 60 & .509 & 99.9 & .999 \\
\hline 70 & .483 & 98.1 & .998 \\
\hline 80 & .459 & 96.4 & .992 \\
\hline 90 & .437 & 94.9 & .992 \\
\hline 600 & .420 & 93.7 & .985 \\
\hline 10 & .407 & 93.3 & .990 \\
\hline 20 & .396 & 93.0 & .999 \\
\hline 30 & .386 & 92.6 & 1.005 \\
\hline 40 & .375 & 92.0 & 1.011 \\
\hline 650 & .366 & 91.4 & 1.019 \\
\hline 60 & .356 & 90.3 & 1.020 \\
\hline 70 & .343 & 88.5 & 1.024 \\
\hline 80 & .330 & 86.3 & 1.019 \\
\hline 90 & .315 & 83.3 & 1.007 \\
\hline 700 & .300 & 80.3 & .997 \\
\hline 10 & .286 & 77.1 & .988 \\
\hline 20 & .271 & 73.7 & .968 \\
\hline
\end{tabular}

T-- Spectral Transmission of Filter at $25^{\circ} \mathrm{C}$

$\checkmark--$ Relative Visibility Function

E-- Relative Energy of $3600^{\circ} \mathrm{K}$

$E^{\prime}--$ Relative Energy of Mean Noon Sunlight at Washington

$E^{\prime \prime}(=T \times E)^{*}--0000--$ Relative Energy of $3600^{\circ} \mathrm{K}$ and Filter Combination

Light Transmission of Filter
for $3600^{\circ} \mathrm{K}=0.506^{* *}$

FILTER FORMULLA

A

Copper Sulphate $\left(\mathrm{CuSO}_{4} \cdot 5 \mathrm{H}_{2} \mathrm{O}\right) \quad 1.199$ grams

Mannite $\left(\mathrm{C}_{6} \mathrm{H}_{8}(\mathrm{OH})_{5}\right) \quad 1.199$ grams

$\begin{array}{lll}\text { Pyridine }\left(\mathrm{C}_{5} \mathrm{H}_{5} \mathrm{~N}\right) & 30.0 \mathrm{cC}\end{array}$

Water (distilled) to make 1000. CC

\section{B}

Cobalt Ammonium Sulphate

$\left(\mathrm{CoSO}_{4} \cdot\left(\mathrm{NH}_{4}\right)_{2} \mathrm{SO}_{4} \cdot 6 \mathrm{H}_{2} \mathrm{O}\right)$ 10.220 grams

Sulphuric Acid (sp.gr. 1.835) $\quad 10.0 \quad \mathrm{cc}$

Water (distilled) to make $1000 . \quad$ cc

These data are for a one centimeter layer each of solutions $A$ and $B$ in a double cell with three plates of borosilicate crown glass (refractive index, D line, $=1.5 \mathrm{I}$ ), each $2.5 \mathrm{~mm}$ thick.

* Adjusted. to make sum of $E^{\prime \prime}-E^{\prime}$ from 400 to $720 \mathrm{~m} \mu$ equal practically to zero

* Factor to be used to multiply the candle-power of the light source to obtain the candle-power of the source-and-filter combination 
$3800^{\circ} \mathrm{K}$ TO MEAN NOON SUNLIGHT AT WASHINGTON.

CHART 18

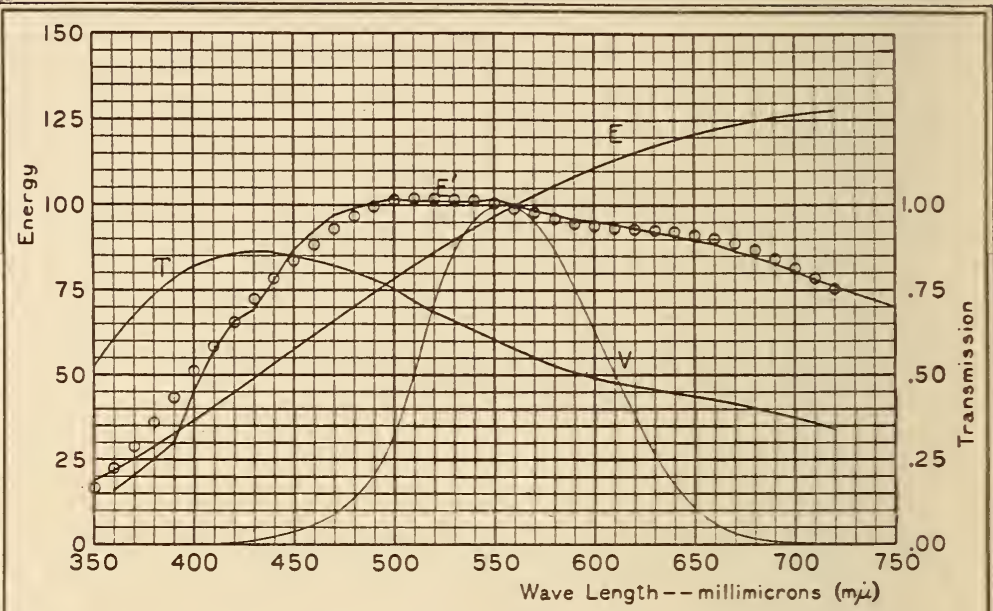

\begin{tabular}{|c|c|c|c|}
\hline$\underset{(m \mu)}{\lambda}$ & $T$ & $E^{\prime \prime *}$ & $E^{\prime \prime} / E^{\prime}$ \\
\hline 350 & 0.526 & 16.6 & \\
\hline 60 & .608 & 22.4 & 1.403 \\
\hline 70 & .680 & 29.0 & 1.419 \\
\hline 80 & .740 & 36.1 & 1.442 \\
\hline 90 & .784 & 43.7 & 1.452 \\
\hline 400 & .823 & 51,1 & 1.131 \\
\hline 10 & .846 & 58.5 & 1.021 \\
\hline 20 & .859 & 65.6 & .996 \\
\hline 30 & .863 & 72.2 & 1.044 \\
\hline 40 & .860 & 78.3 & 1.007 \\
\hline 450 & .849 & 83.7 & .964 \\
\hline 60 & .835 & 88.4 & .958 \\
\hline 70 & .821 & 92.9 & .958 \\
\hline 80 & .804 & 96.8 & .978 \\
\hline 90 & .782 & 99.8 & .992 \\
\hline 500 & .754 & 101.5 & .997 \\
\hline 10 & .721 & 101.9 & 1.007 \\
\hline 20 & .688 & 101.9 & 1.006 \\
\hline 30 & .659 & 101.7 & 1.007 \\
\hline 40 & .632 & 101.3 & 1.004 \\
\hline 550 & .605 & 100.4 & .987 \\
\hline 60 & .577 & 99.1 & .991 \\
\hline 70 & .551 & 97.4 & .990 \\
\hline 80 & .528 & 95.9 & .987 \\
\hline 90 & .508 & 94.6 & .989 \\
\hline 600 & .491 & 93.7 & .984 \\
\hline 10 & .479 & 93.2 & .989 \\
\hline 20 & .468 & 92.9 & .998 \\
\hline 30 & .458 & 92.5 & 1.004 \\
\hline 40 & .448 & 91.8 & 1.009 \\
\hline 650 & .439 & 91.2 & 1.017 \\
\hline $6 C$ & .429 & 90.1 & 1.018 \\
\hline 70 & .417 & 88.5 & 1.024 \\
\hline 80 & .404 & 86.6 & 1.022 \\
\hline 90 & .389 & 84.0 & 1.015 \\
\hline 700 & .374 & 81.3 & 1.010 \\
\hline 10 & .359 & 78.5 & 1.005 \\
\hline 20 & 342 & 75.1 & .988 \\
\hline
\end{tabular}

T-- Spectral Transmission of Filter at $25^{\circ} \mathrm{C}$

$\checkmark--$ Relative Visibility Function

E--Relative Energy of $3800^{\circ} \mathrm{K}$

E'-- Relative Energy of Mean Noon Sunlight at Washington

$E^{\prime \prime}(=T \times E)^{2}-0000-$ Relative Energy of $3800^{\circ} \mathrm{K}$ and Filter Combination

Light Transmission of Filter for $3800^{\circ} \mathrm{K} \quad=0.577$

\section{FILTER FORMULA}

\section{A}

Copper Sulphate $\left(\mathrm{CuSO}_{4} \cdot 5 \mathrm{H}_{2} \mathrm{O}\right)$

Mannite $\left(\mathrm{C}_{6} \mathrm{H}_{8}(\mathrm{OH})_{6}\right)$

Pyridine $\left(\mathrm{C}_{5} \mathrm{H}_{5} \mathrm{~N}\right)$

Water (distilled) to make 1000.

0.955 grams

0.955 grams cc

\section{B}

Cobalt Ammonium Sulphate

$\left(\mathrm{CoSO}_{4} \cdot\left(\mathrm{NH}_{4}\right)_{2} \mathrm{SO}_{4} \cdot 6 \mathrm{H}_{2} \mathrm{O}\right)$ Sulphuric Acid (sp.gr. 1.835) $10.0 \quad$ cc Water (distilled) to make $1000 . \quad \mathrm{cc}$

These data are for a one centimeter layer each of solutions $A$ and $B$ in a double cell with three plates of borosilicate crown glass (refractive index, D line. $=1.51$ ), each $2.5 \mathrm{~mm}$ thick.

* Adjusted to make sum of $E^{\prime \prime}-E^{\prime}$ from 400 to $720 \mathrm{m \mu}$ equal practically to zero

* Factor to be usec to multiply the candle-power of the light source to obtain the candle-power of the source-and-filter combination 
$4000^{\circ} \mathrm{K}$ TO MEAN NOON SUNLIGHT AT WASHINGTON. CHART 20

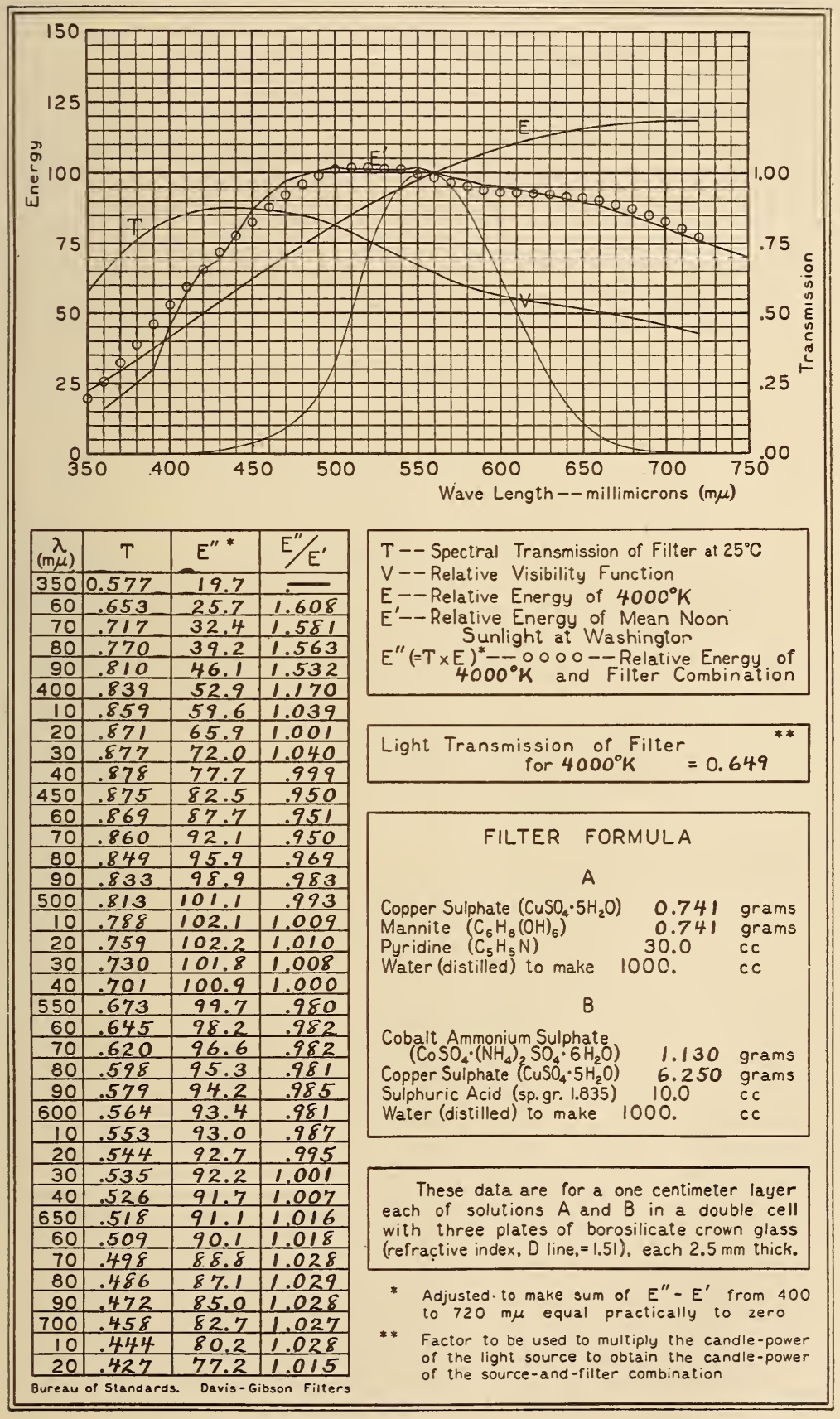


$2848^{\circ} \mathrm{K}$ то $3500^{\circ} \mathrm{K}$

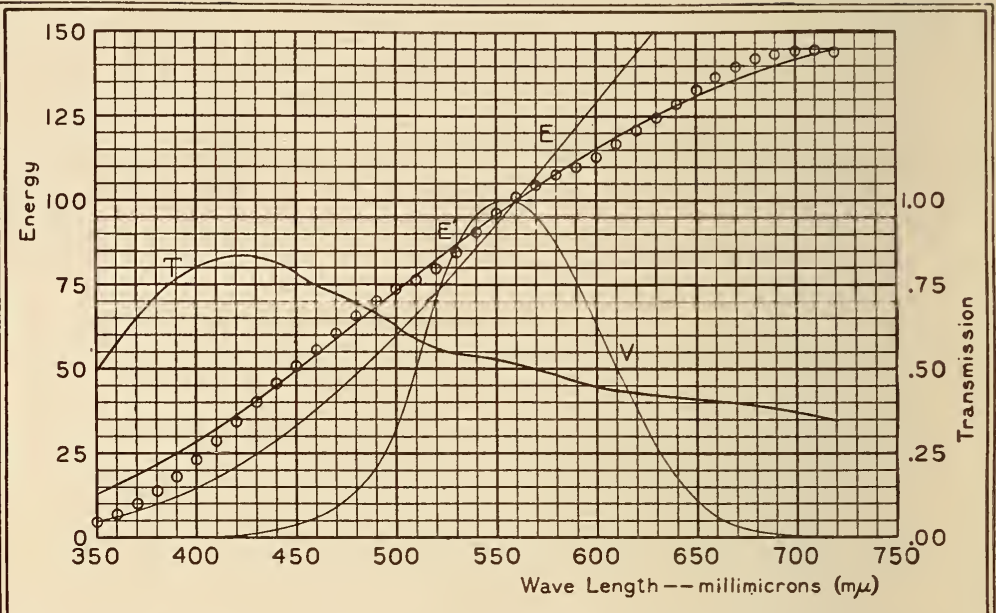

\begin{tabular}{|r|c|c|c|}
\hline $\begin{array}{c}\lambda \\
(\mathrm{m} \mu)\end{array}$ & $T$ & $E^{\prime \prime}$ & $E^{\prime \prime} / E^{\prime}$ \\
\hline 350 & 0.492 & 4.6 & .353 \\
\hline 60 & .577 & 7.0 & .447 \\
\hline 70 & .653 & 10.0 & .541 \\
\hline 80 & .717 & 13.8 & .635 \\
\hline 90 & .768 & 18.2 & .726 \\
\hline 400 & .804 & 23.2 & .806 \\
\hline 10 & .826 & 28.6 & .878 \\
\hline 20 & .836 & 34.4 & .938 \\
\hline 30 & .831 & 40.2 & .982 \\
\hline 40 & 813 & 457 & 1.009 \\
\hline
\end{tabular}

T--Spectral Transmission of Filter at $25^{\circ} \mathrm{C}$

$V$-- Relative Visibility Function

E--Relative Energy of $2848^{\circ} \mathrm{K}$

$E^{\prime}--$ Relative Energy of $3500^{\circ} \mathrm{K}$

$E^{\prime \prime}(=T \times E)^{*}--0000--$ Relative Energy of $2848^{\circ} \mathrm{K}$ and Filter Combination

Light Transmission of Filter
for $2848^{\circ} \mathrm{K}=0.497^{* *}$

\begin{tabular}{|l|l|l|l|}
\hline 450 & .783 & 50.7 & 1.019 \\
\hline 60 & 749 & 55.4 & 1.019 \\
\hline
\end{tabular}

\section{FILTER FORMULA}

\section{A}

Copper Sulphate $\left(\mathrm{CuSO}_{4} \cdot 5 \mathrm{H}_{2} \mathrm{O}\right) \quad 0.113$ grams Mannite $\left(\mathrm{C}_{6} \mathrm{H}_{6}(\mathrm{OH})_{6}\right)$

Pyridine $\left(\mathrm{C}_{5} \mathrm{H}_{5} \mathrm{~N}\right)$

1.113 , grams

Water (distilled) to make 1000.0 C C

\section{B}

Cobalt Ammonium Sulphate

$\left(\mathrm{CoSO}_{4} \cdot\left(\mathrm{NH}_{4}\right)_{2} \mathrm{SO}_{4} \cdot 6 \mathrm{H}_{2} \mathrm{O}\right)$

Copper Sulphate ( $\left.\mathrm{CuSO}_{4} \cdot 5 \mathrm{H}_{2} \mathrm{O}\right)$

Water (distilled) to make 1000

9.780 grams

7.197 grams

$10.0 \quad c c$

\begin{tabular}{|c|c|c|c|}
90 & .462 & 110.1 & .985 \\
\hline 600 & 447 & 113.0 & 979 \\
\hline & .437 & 116.7
\end{tabular}

\begin{tabular}{|l|l|l|l|}
\hline 10 & .437 & 116.7 & .982 \\
\hline
\end{tabular}

\begin{tabular}{l|l|l|l}
\hline 20 & .429 & 120.7 & .989 \\
\hline
\end{tabular}

\begin{tabular}{r|r|r|r}
\hline 30 & .422 & 124.7 & .996 \\
\hline 40 & 416 & 128.6 & 1004
\end{tabular}

\begin{tabular}{|l|l|l|l|}
\hline 550 & .411 & 132.9 & 1.015 \\
\hline 60 & 406 & 136.7 & 1.024 \\
\hline
\end{tabular}

\begin{tabular}{|l|l|l|l|}
\hline 60 & .406 & 136.7 & 1.024 \\
\hline 70 & .399 & 139.7 & 1.028 \\
\hline
\end{tabular}

\begin{tabular}{l|l|l|l}
\hline 80 & .391 & 142.1 & 1.029 \\
\hline
\end{tabular}

\begin{tabular}{l|l|l|l|}
90 & .381 & 143.4 & 1.024
\end{tabular}

\begin{tabular}{l|l|l|l}
700 & .372 & 144.4 & 1.017 \\
\hline
\end{tabular}

\begin{tabular}{l|l|l|l|}
10 & .361 & 144.7 & 1.008 \\
\hline
\end{tabular}

\begin{tabular}{l|l|l|l|}
10 & .361 & 144.7 & 1.008 \\
\hline 20 & .349 & 143.9 & .992 \\
\hline
\end{tabular}

Bureau of Standards. Davis-Gibson Filters

These data are for a one centimeter layer each of solutions $A$ and $B$ in a double cell with three plates of borosilicate crown glass (refractive index. $D$ line $=1.51$ ). each, $2.5 \mathrm{~mm}$ thick.

* Adjusted to make sum of $E^{\prime \prime}-E^{\prime}$ from 400 to $720 \mathrm{~m} \mu$ equal practically to zero

* Factor to be used to multiply the candle-power of the light scurce to obtain the candle-power of the source-and-filter combination 
$2848^{\circ} \mathrm{K}$ TO $4000^{\circ} \mathrm{K}$

CHART 22

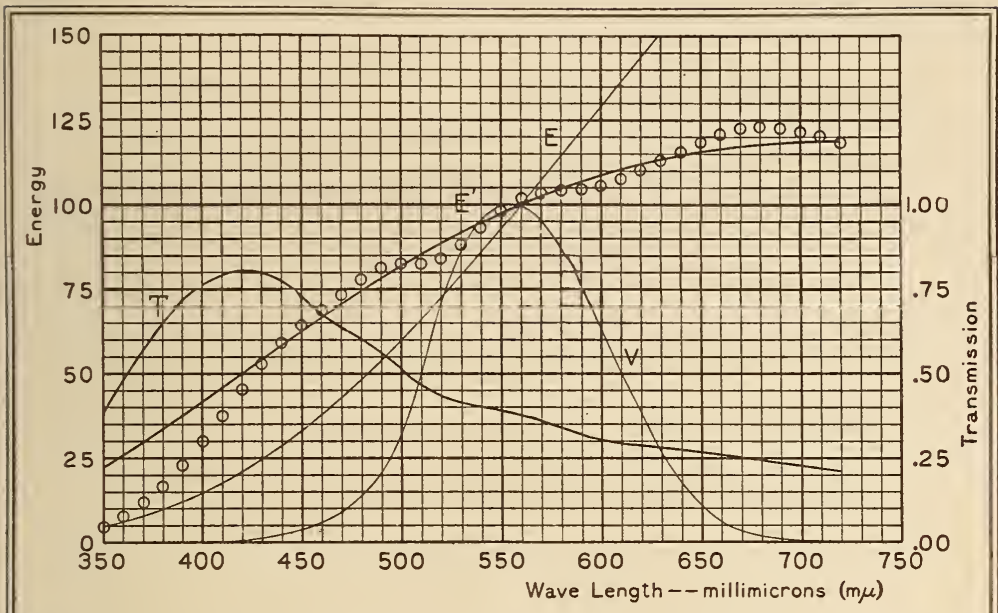

\begin{tabular}{|r|c|c|c|}
\hline $\begin{array}{c}\lambda \\
(\mathrm{m \mu})\end{array}$ & $T$ & $E^{\prime \prime}$ & $E^{\prime \prime} / E^{\prime}$ \\
\hline 350 & 0.390 & 5.0 & .221 \\
\hline 60 & .483 & 8.0 & .308 \\
\hline 70 & .571 & 11.9 & .404 \\
\hline 80 & .650 & 17.0 & .510 \\
\hline 90 & .717 & 23.2 & .621 \\
\hline 400 & .763 & 30.1 & .726 \\
\hline 10 & .793 & 37.6 & .825 \\
\hline 20 & .807 & 45.4 & .913 \\
\hline 30 & .799 & 52.8 & .979 \\
\hline 40 & .771 & 59.3 & 1.020 \\
\hline 450 & .726 & 64.4 & 1.034 \\
\hline 60 & .678 & 68.6 & 1.035 \\
\hline 70 & .639 & 73.3 & 1.043 \\
\hline 80 & .602 & 77.9 & 1.049 \\
\hline 90 & .563 & 81.2 & 1.042 \\
\hline 500 & .514 & 82.4 & 1.010 \\
\hline 10 & .467 & 82.6 & .971 \\
\hline 20 & .433 & 84.1 & .951 \\
\hline 30 & .416 & 88.1 & .962 \\
\hline 40 & .406 & 93.3 & .988 \\
\hline 550 & .394 & 98.2 & 1.009 \\
\hline 60 & .379 & 101.5 & 1.015 \\
\hline 70 & .360 & 103.3 & 1.009 \\
\hline 80 & .340 & 104.1 & .994 \\
\hline 90 & .321 & 104.6 & .979 \\
\hline 600 & .305 & 105.5 & .971 \\
\hline 10 & .295 & 107.7 & .975 \\
\hline 20 & .287 & 110.3 & .986 \\
\hline 30 & .280 & 113.0 & .998 \\
\hline 40 & .273 & 115.5 & 1.009 \\
\hline 650 & .268 & 118.4 & 1.025 \\
\hline 60 & .262 & 120.9 & 1.040 \\
\hline 70 & .255 & 122.3 & 1.045 \\
\hline 80 & .248 & 123.1 & 1.046 \\
\hline 90 & .238 & 122.5 & 1.036 \\
\hline 700 & .229 & 121.6 & 1.026 \\
\hline 10 & .219 & 120.2 & 1.012 \\
\hline 20 & .209 & 117.9 & .994 \\
\hline
\end{tabular}

T-- Spectral Transmission of Filter at $25^{\circ} \mathrm{C}$

V-- Relative Visibility Function

$E--$ Relative Energy of $2848^{\circ} \mathrm{K}$

$E^{\prime}$-- Relative Energy of $4000^{\circ} \mathrm{K}$

$E^{\prime \prime}(=T \times E)^{*}--0000--$ Relative Energy of $2848^{\circ} \mathrm{K}$ and Filter Combination

Light Transmission of Filter

for $2848^{\circ} \mathrm{K}=0.361$

\section{FILTER FORMULA}

\section{A}

Copper Sulphate $\left(\mathrm{CuSO}_{4} \cdot 5 \mathrm{H}_{2} \mathrm{O}\right) \quad 1.726$ grams Mannite $\left(\mathrm{C}_{6} \mathrm{H}_{8}(\mathrm{OH})_{6}\right) \quad 1.726$ grams Pyridine $\left(\mathrm{C}_{5} \mathrm{H}_{5} \mathrm{~N}\right) \quad 30 . \mathrm{C}^{\mathrm{C}} \mathrm{CC}$ Water (distilled) to make 1000 . CC

\section{B}

Cobalt Ammonium Sulphate

$\left(\mathrm{CoSO} \mathrm{SH}_{4} \cdot\left(\mathrm{NH}_{4}\right)_{2} \mathrm{SO}_{4} \cdot 6 \mathrm{H}_{2} \mathrm{O}\right) \quad 15.133$ grams Copper Sulphate $\left(\mathrm{CuSO}_{4} \cdot 5 \mathrm{H}_{2} \mathrm{O}\right) \quad 11.220$ grams Sulphuric Acid (sp.gr. 1.835) $\quad 10.0 \quad \mathrm{cc}$ Water (distılled) to make $1000 . \quad$ cc

These data are for a one centimeter layer each of solutions $A$ and $B$ in a double cell with three plates of borosilicate crown glass (refractive index, D line, $=1.51$ ), each $2.5 \mathrm{~mm}$ thick.

* Adjusted to make sum of $E^{\prime \prime}-E^{\prime}$ from 400 to $720 \mathrm{~m} \mu$ equal practically to zero

* Factor to be used to multiply the candle-power of the light source to obtain the candle-power of the source-and-filter combination 
$2848^{\circ} \mathrm{K}$ To $5000^{\circ} \mathrm{K}$ CHART 24

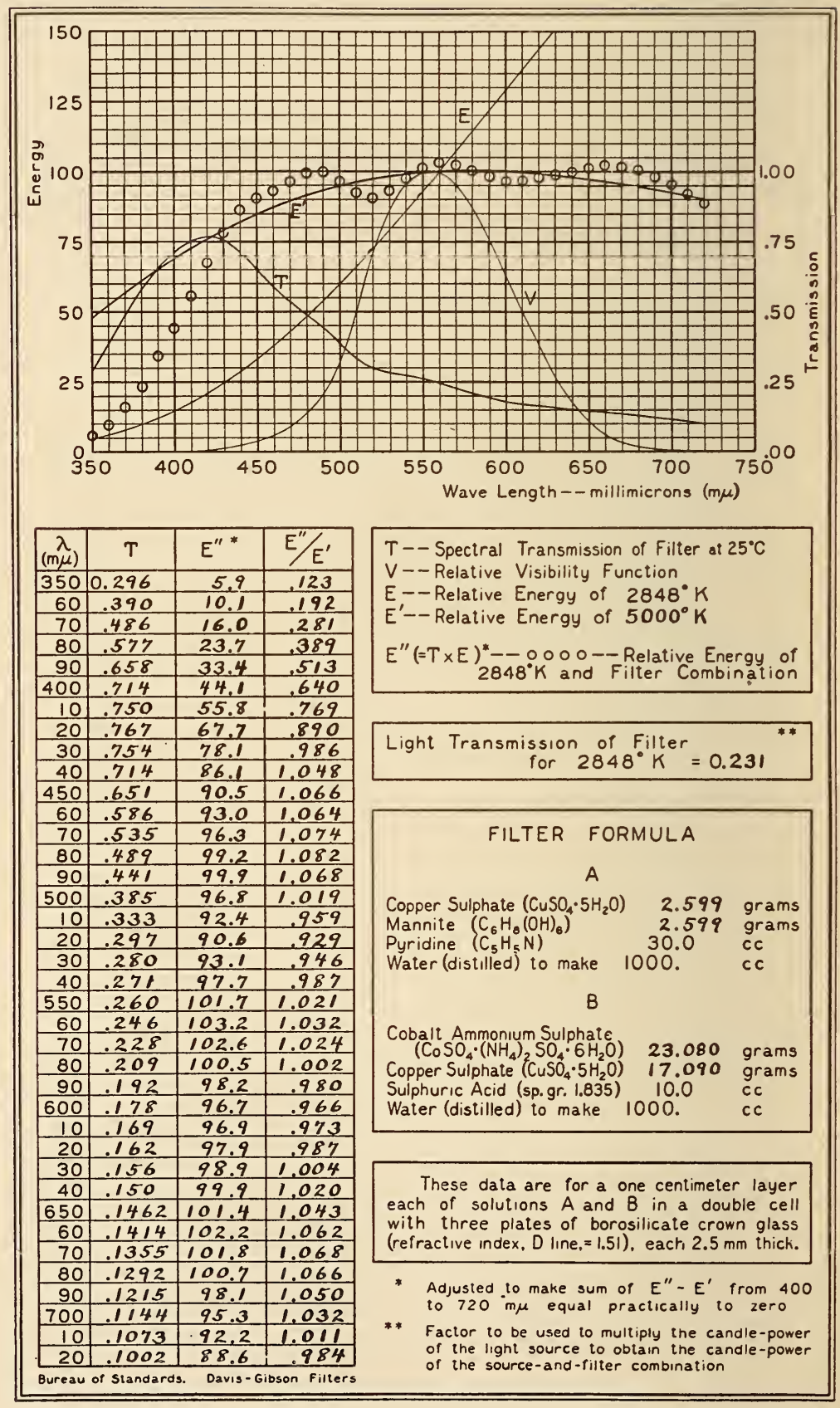




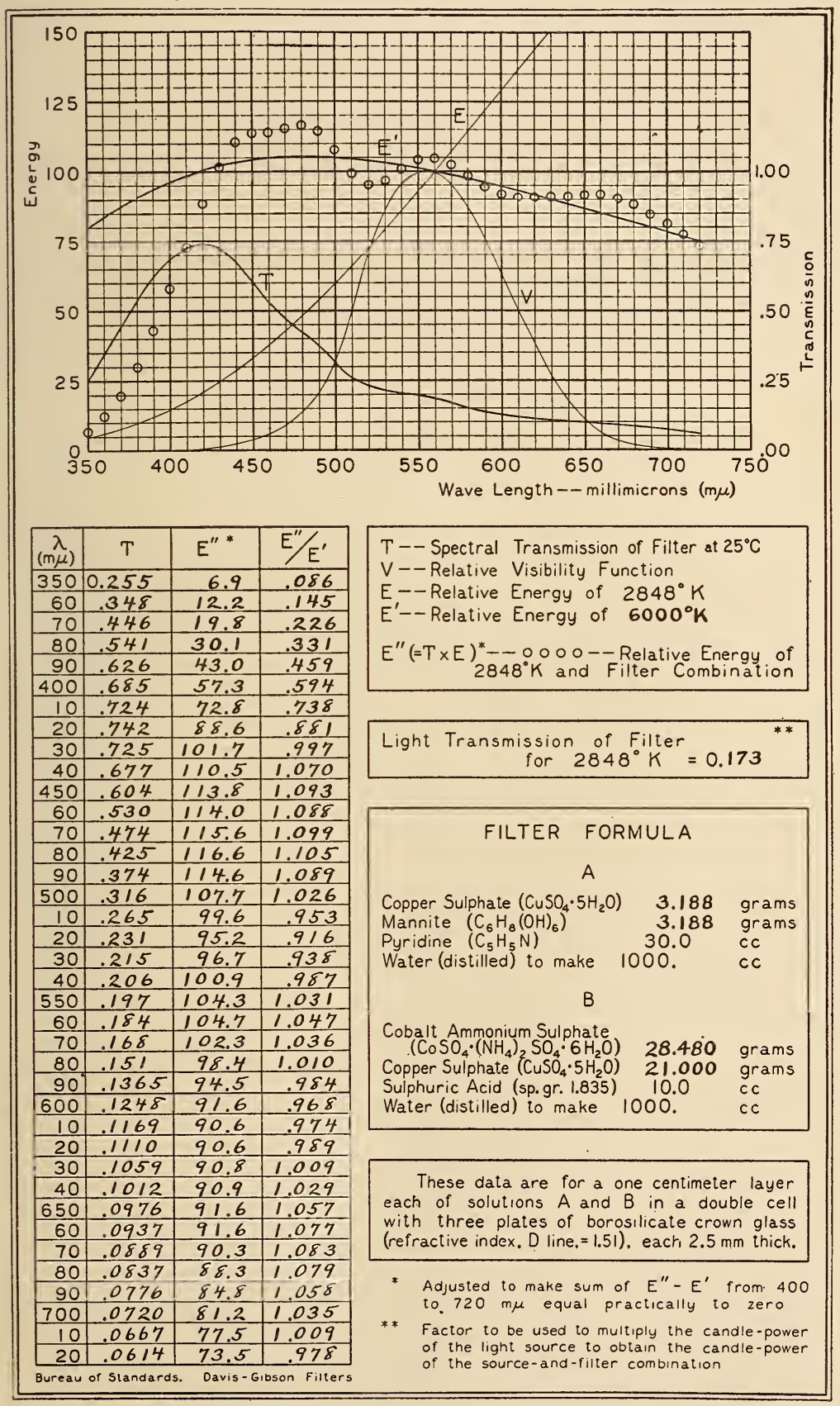


$2848^{\circ} \mathrm{K}$ To $7000^{\circ} \mathrm{K}$

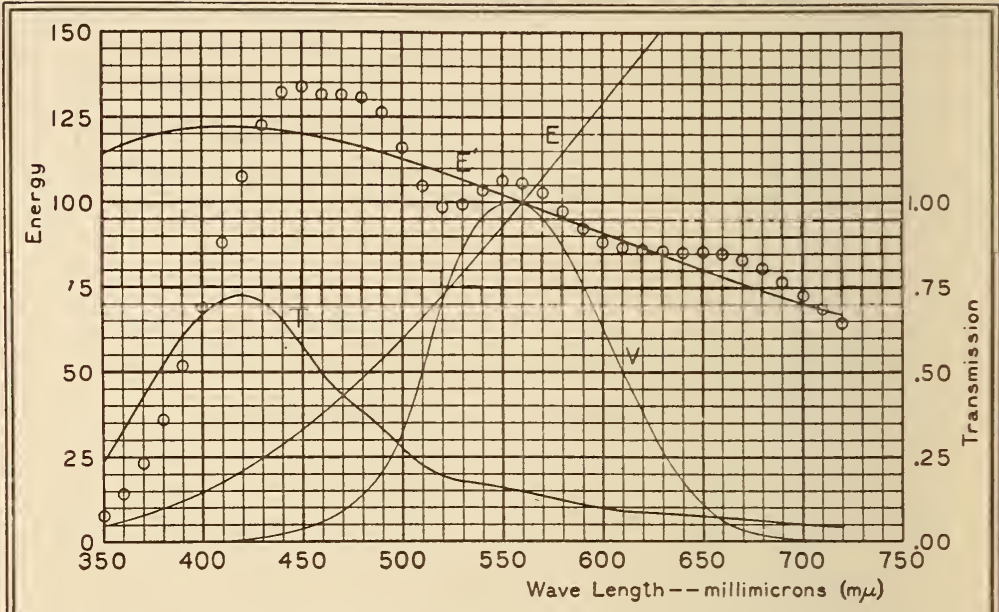

\begin{tabular}{|c|c|c|c|}
\hline$\underset{(m \mu)}{\lambda}$ & $T$ & $E^{\prime \prime *}$ & $E^{\prime \prime} / E^{\prime}$ \\
\hline 350 & 0.234 & 7.8 & .069 \\
\hline 60 & .325 & 14.1 & .121 \\
\hline 70 & .423 & 23.3 & .197 \\
\hline 80 & .520 & 35.9 & .299 \\
\hline 90 & .607 & 51.7 & .427 \\
\hline 400 & .667 & 69.1 & .567 \\
\hline 10 & .706 & 88.0 & .720 \\
\hline 20 & .725 & 107.3 & .878 \\
\hline 30 & .705 & 122.6 & 1.007 \\
\hline 40 & .652 & 132.0 & 1.089 \\
\hline 450 & .573 & 133.7 & 1.113 \\
\hline 60 & .494 & 131.6 & 1.106 \\
\hline 70 & .435 & 131.4 & 1.117 \\
\hline 80 & .384 & 130.6 & 1.125 \\
\hline 90 & .332 & 126.3 & 1.105 \\
\hline 500 & .275 & 116.1 & 1.031 \\
\hline 10 & .225 & 104.8 & .948 \\
\hline 20 & .193 & 98.5 & .906 \\
\hline 30 & .178 & 99.3 & .932 \\
\hline 40 & .170 & 103.3 & .988 \\
\hline 550 & .162 & 106.3 & 1.039 \\
\hline 60 & .150 & 105.9 & 1.059 \\
\hline 70 & .1356 & 102.5 & 1.048 \\
\hline 80 & .1205 & 97.3 & 1.018 \\
\hline 90 & .1073 & 92.2 & .988 \\
\hline 600 & .0971 & 88.3 & .970 \\
\hline 10 & .0901 & 86.7 & .976 \\
\hline 20 & .0850 & 86.1 & .993 \\
\hline 30 & .0806 & 85.7 & 1.015 \\
\hline 40 & .0765 & 85.3 & 1.035 \\
\hline 650 & .0735 & 85.5 & 1.066 \\
\hline 60 & .0700 & 85.0 & 1.087 \\
\hline 70 & .0659 & 83.1 & 1.093 \\
\hline 80 & .0616 & 80.6 & 1.088 \\
\hline 90 & .0565 & 76.6 & 1.062 \\
\hline 700 & .0519 & 72.6 & 1.035 \\
\hline 10 & .0476 & 68.6 & 1.004 \\
\hline 20 & .0434 & 64.1 & .970 \\
\hline
\end{tabular}

T-- Spactral Transmission of Filter at $25^{\circ} \mathrm{C}$

$V--$ Relative Visibility Function

E-- Relative Energy of $2848^{\circ} \mathrm{K}$

$E^{\prime}--$ Relative Energy of $7000^{\circ} \mathrm{K}$

$E^{\prime \prime}(=T \times E)^{*}--0000--$ Relative Energy of $2848^{\circ} \mathrm{K}$ and Filter Combination

Light Transmission of Filter

for $2848^{\circ} \mathrm{K}=0.1407$

\section{FILTER FORMULA}

\section{A}

Copper Sulphate $\left(\mathrm{CuSO}_{4} \cdot 5 \mathrm{H}_{2} \mathrm{O}\right) \quad 3.605$ grams Mannite $\left(\mathrm{C}_{6} \mathrm{H}_{8}(\mathrm{OH})_{6}\right) \quad 3.605$ grams Pyridine $\left(\mathrm{C}_{5} \mathrm{H}_{5} \mathrm{~N}\right) \quad 30.0 \mathrm{cC}$ Water (distilled) to make 1000 . cc

\section{B}

Cobalt Ammonium Sulphate

$\left(\mathrm{CoSO}_{4} \cdot\left(\mathrm{NH}_{4}\right)_{2} \mathrm{SO}_{4} \cdot 6 \mathrm{H}_{2} \mathrm{O}\right) \quad 32.400$ grams Copper Sulphate $\left(\mathrm{CuSO}_{4} \cdot 5 \mathrm{H}_{2} \mathrm{O}\right) \quad 23.800$ grams Sulphuric Acid (sp.gr. 1.835) $\quad 10.0 \quad \mathrm{cc}$ Water (distilled) to make $1000 . \quad$ cc

These data are for a one centimeter layer each of solutions $A$ and $B$ in a double cell with three plates of borosilicate crown glass (refractive index. D line. $=1.51$ ), each $2.5 \mathrm{~mm}$ thick.

* Adjusted to make sum of $E^{\prime \prime}-E^{\prime}$ from 40.0 to $720 \mathrm{~m} \mu$ equal practically to zero

** Factor to be used to multiply the candle-power of the light source to obtain the candie-power of the source-and-filter combination 


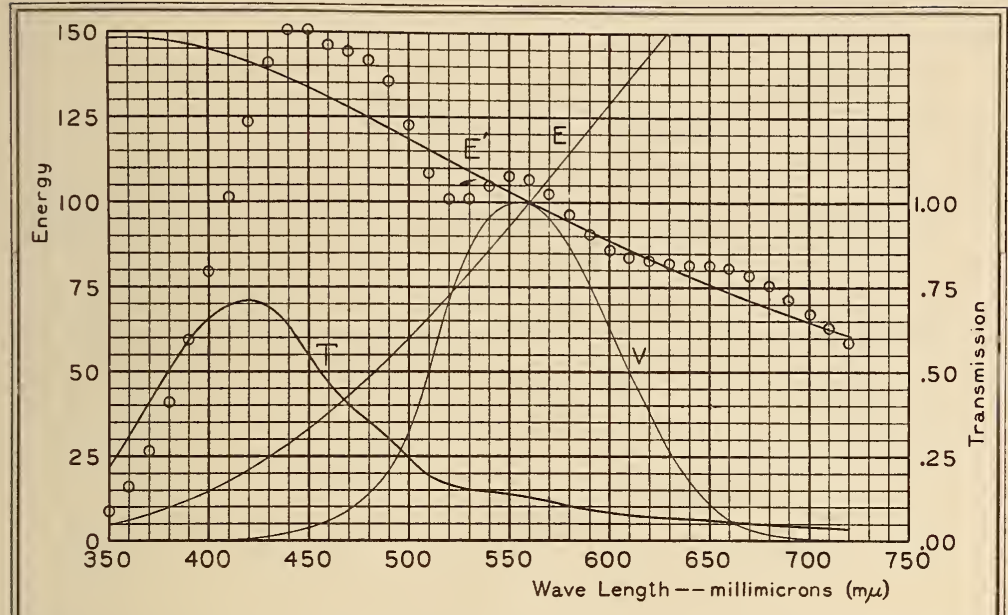

\begin{tabular}{|c|c|c|c|}
\hline $\begin{array}{c}\lambda \\
(\mathrm{m} \mu)\end{array}$ & $T$ & $E^{\prime \prime}$ & $E^{\prime \prime} / E^{\prime}$ \\
\hline 350 & 0.221 & 8.7 & .059 \\
\hline 60 & .312 & 15.9 & .107 \\
\hline 70 & .409 & 26.4 & .178 \\
\hline 80 & .506 & 41.0 & .278 \\
\hline 90 & .594 & 59.4 & .406 \\
\hline 400 & .654 & 79.5 & .548 \\
\hline 10 & .693 & 101.3 & .708 \\
\hline 20 & .712 & 123.5 & .877 \\
\hline 30 & .691 & 140.8 & 1.017 \\
\hline 40 & .634 & 150.4 & 1.106 \\
\hline 450 & .550 & 150.5 & 1.128 \\
\hline 60 & .468 & 146.2 & 1.120 \\
\hline 70 & .407 & 144.3 & 1.132 \\
\hline 80 & .356 & 141.8 & 1.139 \\
\hline 90 & .304 & 135.4 & 1.115 \\
\hline 500 & .247 & 122.4 & 1.035 \\
\hline 10 & .199 & 108.7 & .943 \\
\hline 20 & .168 & 100.8 & .900 \\
\hline 30 & .155 & 101.1 & .927 \\
\hline 40 & .1477 & 104.9 & .990 \\
\hline 550 & .1402 & 107.7 & 1.045 \\
\hline 60 & .1292 & 106.7 & 1.067 \\
\hline 70 & .1157 & 102.4 & 1.056 \\
\hline 80 & .1019 & 96.4 & 1.024 \\
\hline 90 & .0899 & 90.5 & .990 \\
\hline 600 & .0807 & 86.0 & .972 \\
\hline 100 & .0744 & 83.8 & .976 \\
\hline 20 & .0698 & 82.9 & .996 \\
\hline 30 & .0660 & 82.2 & 1.019 \\
\hline 40 & .0623 & 81.4 & 1.041 \\
\hline 650 & .0596 & 81.3 & 1.074 \\
\hline 60 & .0566 & 80.5 & 1.097 \\
\hline 70 & .0530 & 78.4 & 1.102 \\
\hline 80 & .0493 & 75.5 & 1.097 \\
\hline 90 & .0449 & 71.3 & 1.068 \\
\hline 700 & .0409 & 67.1 & 1.037 \\
\hline 10 & .0372 & .62 .9 & 1.004 \\
\hline 20 & .0337 & 58.7 & .967 \\
\hline $8 u r e a u 0$ & 512010 ards. & $0 a v i s-6 i b s o n$ & Filters \\
\hline
\end{tabular}

T--Spectral Transmission of Filter at $25^{\circ} \mathrm{C}$

V--Relative Visibility Function

E--Relative Energy of $2848^{\circ} \mathrm{K}$

$E^{\prime}--$ Relative Energy of $8000^{\circ} \mathrm{K}$ $E^{\prime \prime}(=T \times E)^{*}--\circ \circ \circ \circ--$ Relative Energy of
$2848^{\circ} \mathrm{K}$ and Filter Combination

Light Transmission of Filter

for $2848^{\circ} \mathrm{K}=0.1211$

FILTER FORMULA

A

Copper Sulphate $\left(\mathrm{CuSO}_{4} \cdot 5 \mathrm{H}_{2} \mathrm{O}\right) \quad 3.9160 \cdot$ grams Mannite $\left(\mathrm{C}_{6} \mathrm{H}_{8}(\mathrm{OH})_{6}\right) \quad 3.916$ grams Pyridine $\left(\mathrm{C}_{5} \mathrm{H}_{5} \mathrm{~N}\right) \quad 30.0 \mathrm{cc}$ Water (distilled) to make 1000 . CC

\section{B}

Cobalt Ammonium Sulphate $\left(\mathrm{CoSO}_{4} \cdot\left(\mathrm{NH}_{4}\right)_{2} \mathrm{SO}_{4} \cdot 6 \mathrm{H}_{2} \mathrm{O}\right)$ Copper Sulphate $\left(\mathrm{CuSO}_{4} \cdot 5 \mathrm{H}_{2} \mathrm{O}\right)$

Sulphuric Acid (sp.gr. I.835) Water (distilled) to make 1000.

35.355 grams 25.800 grams . cc CC

These data are for a one centimeter layer each of solutions $A$ and $B$ in a double cell with three plates of borosilicate crown glass (refractive index, D line, $=1.51$ ), each, $2.5 \mathrm{~mm}$ thick.

* Adjusted to make sum of $E^{\prime \prime}-E^{\prime}$ from 400 to $720 \mathrm{~m} \mu$ equal practically to zero

* Factor to be used to muitiply the candle-power of the light source to obtain the candle-power of the source-and-filter combination 


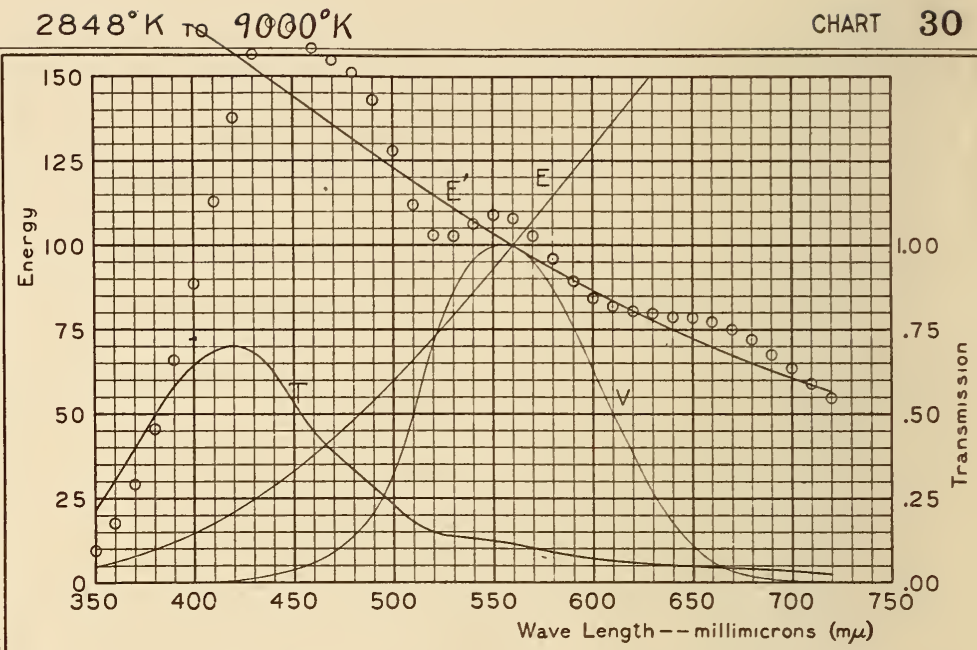

\begin{tabular}{|c|c|c|c|}
\hline$\underset{(m \mu)}{\lambda}$ & $\mathrm{T}$ & $E^{\prime \prime *}$ & $E^{\prime \prime} / E^{\prime}$ \\
\hline 350 & 0.213 & 9.4 & 052 \\
\hline 60 & .303 & 17.4 & .097 \\
\hline 70 & .400 & 29.2 & .166 \\
\hline 80 & .498 & 45.4 & .263 \\
\hline 90 & .586 & 66.0 & .391 \\
\hline 400 & .645 & 88.4 & .535 \\
\hline 10 & 684 & 112.8 & .700 \\
\hline 20 & 703 & 137.5 & .875 \\
\hline 30 & .680 & 156.4 & 1.023 \\
\hline 40 & .620 & 166.1 & 1.118 \\
\hline 450 & .534 & 164.8 & 1.142 \\
\hline 60 & .449 & 158.4 & 1.132 \\
\hline 70 & .388 & 155.1 & 1.143 \\
\hline 80 & .336 & 151.2 & 1.151 \\
\hline 90 & .284 & 143.0 & 1.124 \\
\hline 500 & .229 & 127.7 & 1.038 \\
\hline 10 & .182 & 111.9 & .940 \\
\hline 20 & .152 & $102: 8$ & .894 \\
\hline 30 & .1390 & 102.6 & .923 \\
\hline 40 & .1326 & 106.3 & .991 \\
\hline 550 & .1255 & 108.8 & 1.050 \\
\hline 60 & .1152 & 107.4 & 1.074 \\
\hline 70 & .1026 & 102.5 & 1.062 \\
\hline 80 & .0897 & 95.7 & 1.028 \\
\hline 90 & .0786 & 89.2 & .992 \\
\hline 600 & .0700 & 84.3 & .971 \\
\hline 10 & .0643 & 81.8 & .978 \\
\hline 20 & .0602 & 80.6 & .998 \\
\hline 30 & .0567 & 79.7 & 1.023 \\
\hline 40 & .0534 & 78.6 & 1.045 \\
\hline 650 & .0509 & 78.4 & 1.080 \\
\hline 60 & .0482 & 77.3 & 1.105 \\
\hline 70 & .0450 & 75.0 & 1.110 \\
\hline 80 & .0416 & 72.0 & 1.104 \\
\hline 90 & .0377 & 67.6 & 1.073 \\
\hline 700 & .0342 & 63.3 & 1.041 \\
\hline 10 & .0310 & 59.0 & 1.006 \\
\hline 20 & 0279 & 54.8 & .967 \\
\hline
\end{tabular}

$\mathrm{T}--$ Spectral Transmission of Filter at $25^{\circ} \mathrm{C}$

$V$-- Relative Visibility Function

E-- Relative Energy of $2848^{\circ} \mathrm{K}$

$E^{\prime}--$ Relative Energy of $9000^{\circ} \mathrm{K}$

$E^{\prime \prime}(=T \times E)^{*}--\circ 000-$ Relative Energy of $2848^{\circ} \mathrm{K}$ and Filter Combination
Light Transmission of Filter for $2848^{\circ} \mathrm{K}=0.1082$.

FILTER FORMULA

\section{A}

\begin{tabular}{|c|c|c|}
\hline $\begin{array}{l}\text { Copper Sulphate }\left(\mathrm{CuSO}_{4} \cdot 5 \mathrm{H}_{2} \mathrm{O}\right) \\
\text { Mannite }\left(\mathrm{C}_{6} \mathrm{H}_{8}(\mathrm{OH})_{6}\right) \\
\text { Pyridine }\left(\mathrm{C}_{5} \mathrm{H}_{5} \mathrm{~N}\right) \\
\text { Water (distilled) to make }\end{array}$ & $\begin{array}{l}4.154 \\
4.154 \\
30.0 \\
1000\end{array}$ & $\begin{array}{l}\text { grams } \\
\text { grams } \\
\text { cc } \\
\text { cc }\end{array}$ \\
\hline \multicolumn{3}{|l|}{$B$} \\
\hline $\begin{array}{l}\text { Cobalt Ammonium Sulphate } \\
\left(\mathrm{CoSO}_{4} \cdot\left(\mathrm{NH}_{4}\right)_{2} \mathrm{SO}_{4} \cdot 6 \mathrm{H}_{2} \mathrm{O}\right) \\
\text { Copper Sulphate }\left(\mathrm{CuSO}_{4} \cdot 5 \mathrm{H}_{2} \mathrm{O}\right) \\
\text { Sulphuric Acid (sp.gr. } 1.835) \\
\text { Water (distılled) to make }\end{array}$ & $\begin{array}{l}37.550 \\
27.290 \\
10.0 \\
1000 .\end{array}$ & $\begin{array}{l}\text { grams } \\
\text { grams } \\
\text { cc } \\
c c\end{array}$ \\
\hline
\end{tabular}

These data are for a one centimeter layer each of solutions $A$ and $B$ in a double cell with three plates of borosilicate crown glass (refractive index. D line $=1.51$ ), eacti, $2.5 \mathrm{~mm}$ thick.

* Adjusted to make sum of $E^{\prime \prime}-E^{\prime}$ from 400 to $720 \mathrm{~m} \mu$ equal practically to zero

** Factor to be used to multiply the candle-power of the light source to obtain the canale-power of the source-and-filter combination 


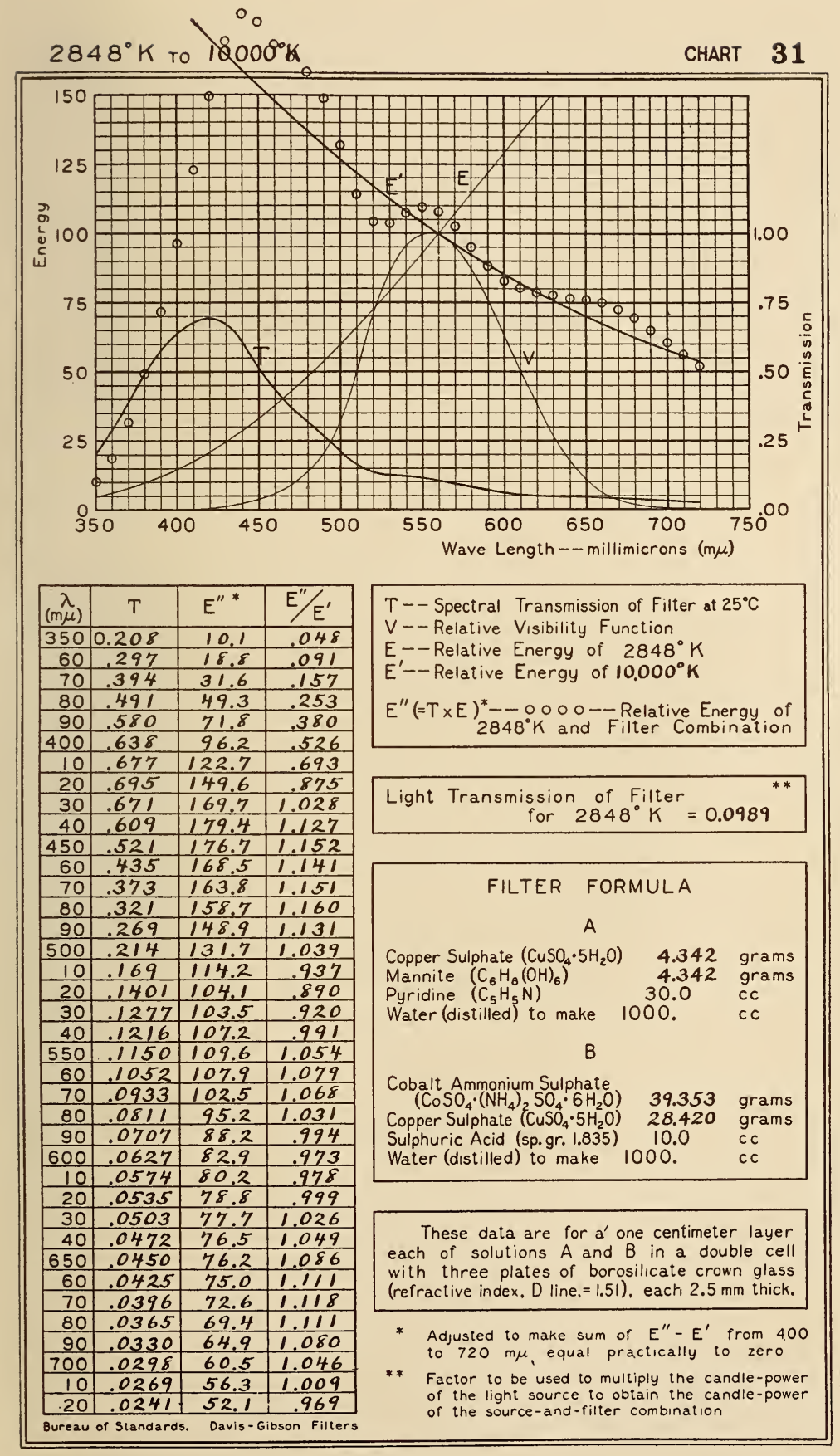

$13416^{\circ}-31-11$ 


\section{$2848^{\circ} \mathrm{K}$ TO SUNLIGHT OUTSIDE EARTH'S ATMOSPHERE CHART 32}

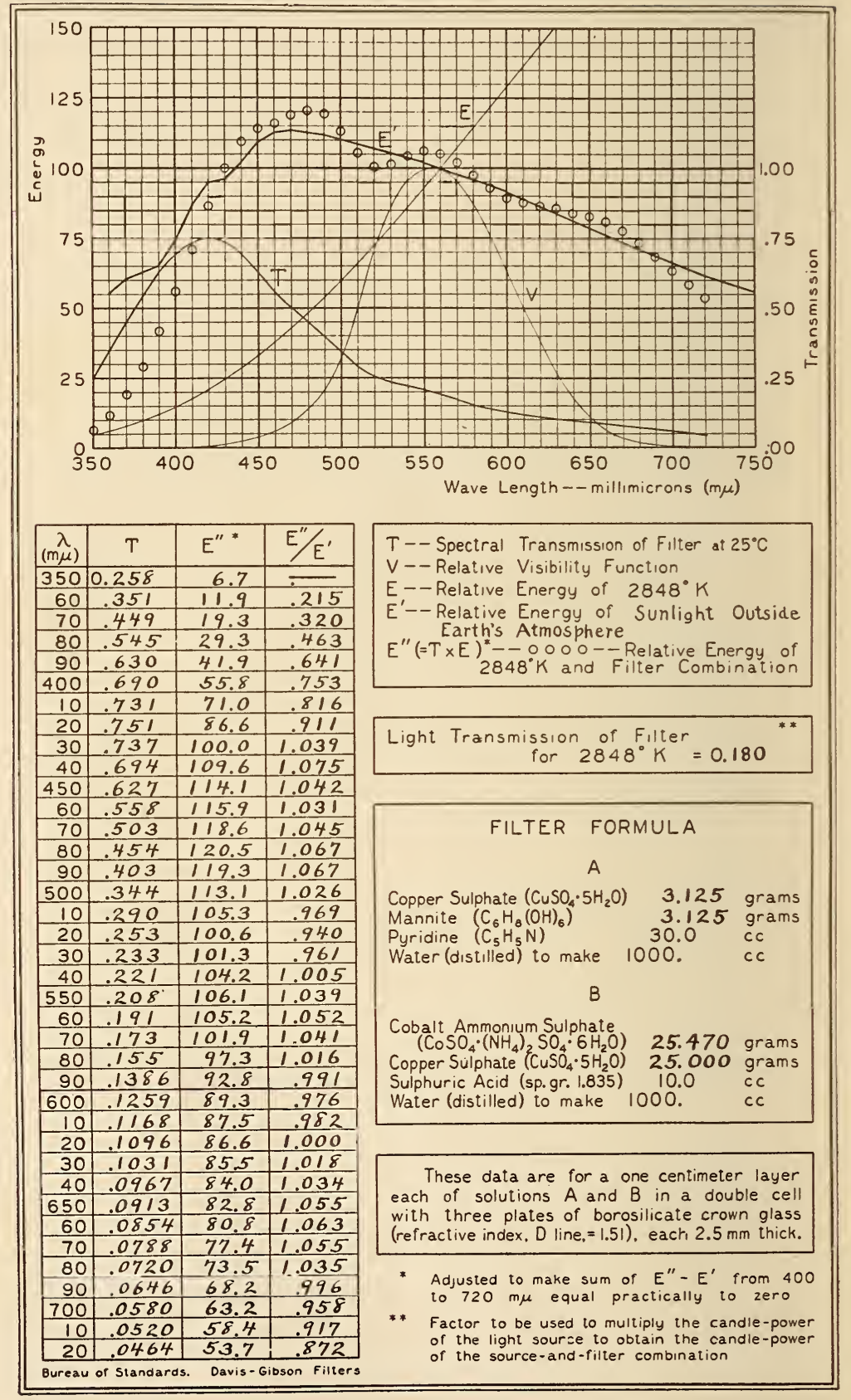


$2848^{\circ} \mathrm{K}$ TO ABBOT-PRIEST SUNLIGHT

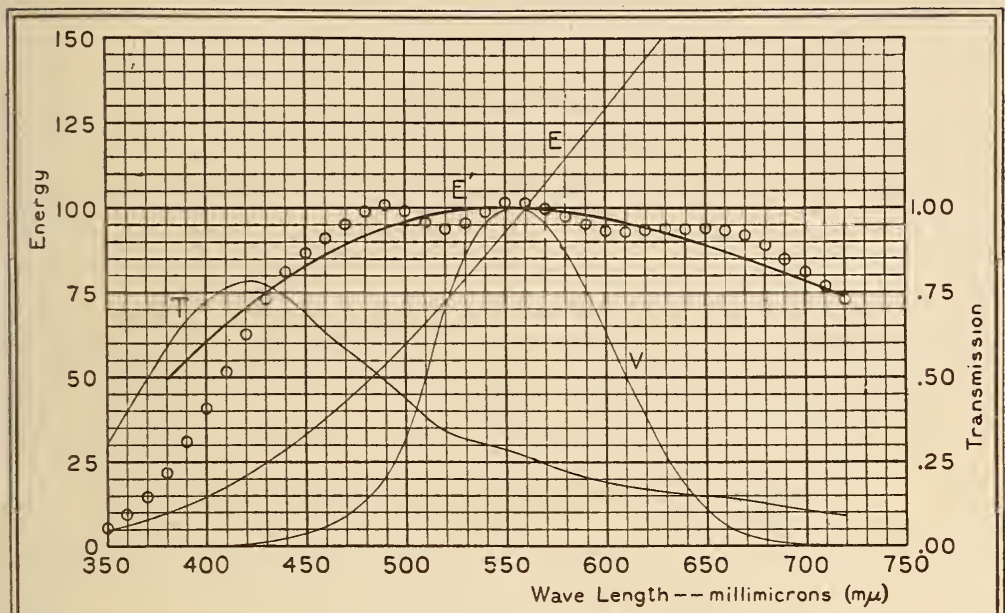

\begin{tabular}{|c|c|c|c|}
\hline$\underset{(m \mu)}{\lambda}$ & $\mathrm{T}$ & $E^{\prime \prime}$ & $E^{\prime \prime} / E^{\prime}$ \\
\hline 350 & 0.306 & 5.5 & - \\
\hline 60 & .401 & 9.4 &.- \\
\hline 70 & .497 & 14.8 &. \\
\hline 80 & .587 & 22.0 & .442 \\
\hline 90 & .667 & 30.8 & .559 \\
\hline 400 & .724 & 40.7 & .674 \\
\hline 10 & .762 & 51.4 & .786 \\
\hline 20 & .781 & 62.6 & .891 \\
\hline 30 & .772 & 72.8 & .972 \\
\hline 40 & .739 & 81.1 & 1.025 \\
\hline 450 & .686 & 86.7 & 1.045 \\
\hline 60 & .628 & 90.6 & 1.048 \\
\hline 70 & .581 & 95.1 & 1.063 \\
\hline 80 & .537 & 99.0 & 1.073 \\
\hline 90 & .489 & 100.7 & 1.065 \\
\hline 500 & .433 & 99.0 & 1.026 \\
\hline 10 & .379 & 95.6 & .976 \\
\hline 20 & .339 & 93.9 & .948 \\
\hline 30 & $.3 / 6$ & 95.6 & .957 \\
\hline 40 & .301 & 98.8 & .985 \\
\hline 550 & .285 & 101.1 & 1.008 \\
\hline 60 & .266 & 101.4 & 1.014 \\
\hline 70 & .244 & 99.9 & 1.002 \\
\hline 80 & .223 & 97.5 & .983 \\
\hline 90 & .204 & 95.0 & .967 \\
\hline 600 & .189 & 93.3 & .962 \\
\hline 10 & .179 & 93.0 & .972 \\
\hline 20 & .170 & 93.4 & .994 \\
\hline 30 & .163 & 93.7 & 1.017 \\
\hline 40 & .155 & 93.6 & 1.032 \\
\hline 650 & .1489 & 93.8 & 1.058 \\
\hline 60 & .1419 & 93.2 & 1.071 \\
\hline 70 & .1338 & 91.4 & 1.078 \\
\hline 80 & .1254 & 88.8 & 1.072 \\
\hline 90 & .1157 & 84.9 & 1.054 \\
\hline 700 & .1069 & 80.9 & 1.036 \\
\hline 10 & .0985 & 76.9 & 1.013 \\
\hline 20 & .0904 & 72.7 & .984 \\
\hline
\end{tabular}

$\mathrm{T}$-- Spectral Transmission of Filter at $25^{\circ} \mathrm{C}$

$V--$ Relative Visibility Function

E--Relative Energy of $2848^{\circ} \mathrm{K}$

$E^{\prime}--$ Relative Energy of Abbot-Priest Sun $E^{\prime \prime}(=T \times E)^{*}-10000--$ Relative Energy of
$2848^{\circ} \mathrm{K}$ and Filter Combination

Light Transmission of Filter

for $2848^{\circ} \mathrm{K}=0.251$

\section{FILTER FORMULA}

\section{A}

Copper Sulphate $\left(\mathrm{CuSO}_{4} \cdot 5 \mathrm{H}_{2} \mathrm{O}\right)$

Mannite $\left(\mathrm{C}_{6} \mathrm{H}_{8}(\mathrm{OH})_{6}\right)$

Pyridine $\left(\mathrm{C}_{5} \mathrm{H}_{5} \mathrm{~N}\right)$ Water (distılled) to make 1000. CC

2.477 grams

2.477 grams

\section{B}

Cobalt Ammonium Sulphate $\left(\mathrm{CoSO} \cdot\left(\mathrm{NH}_{4}\right)_{2} \mathrm{SO}_{4} \cdot 6 \mathrm{H}_{2} \mathrm{O}\right) \quad 18.955$ grams Copper Sulphate (CuSO $\left.4 \mathrm{H}_{2} \mathrm{O}\right) \quad 19.020$ grams Sulphurıc Acid (sp.gr. 1.835) $\quad 10.0 \quad$ cc Water (distilled) to make $1000 . \quad$ cc

These data are for a one centimeter layer each of solutions $A$ and $B$ in a double cell with three plates of borosilicate crown glass (refractive index. $D$ line. $=1.51$ ), each $2.5 \mathrm{~mm}$ thick.

- Adjusted to make sum of $E^{\prime \prime}-E^{\prime}$ from 400 to $720 \mathrm{m \mu}$ equal practically to zero

* Factor to be used to multiply the candie-power of the light source to obtain the candle-power of the source-and-filter combination 
$2848^{\circ} \mathrm{K}$ TO NOON SUNLIGHTAT WASHINGTON JUNE 21 CHART 34

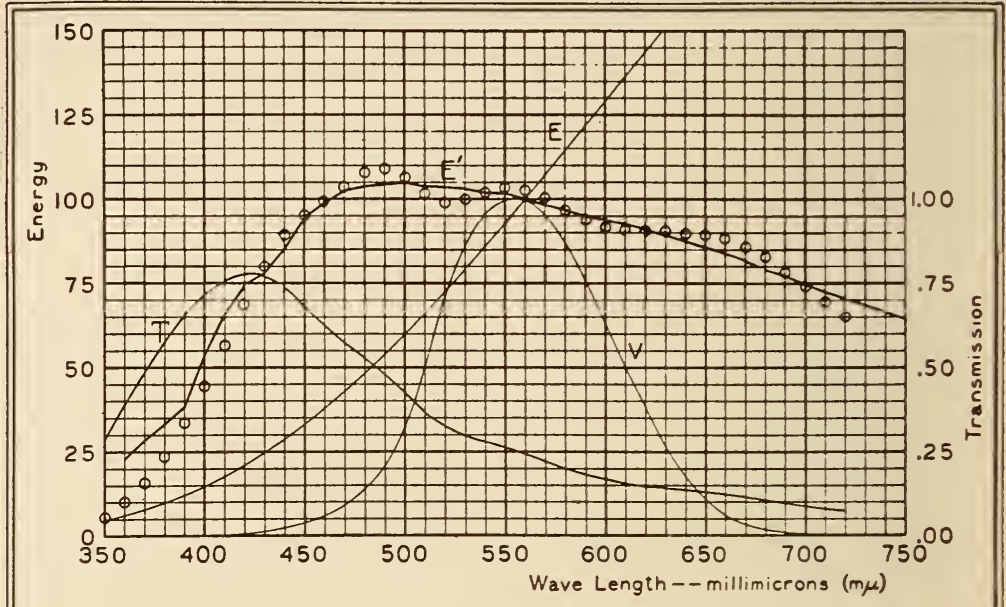

\begin{tabular}{|c|c|c|c|}
\hline$\underset{(m \mu)}{\lambda}$ & $\mathrm{T}$ & $E^{\prime \prime}$ & $E^{\prime \prime} / E^{\prime}$ \\
\hline 350 & 0.290 & 5.8 & 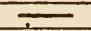 \\
\hline 60 & .385 & 10.0 & .440 \\
\hline 70 & .481 & 15.9 & .559 \\
\hline 80 & .574 & 23.7 & .715 \\
\hline 90 & .657 & 33.5 & .875 \\
\hline 400 & .715 & 44.4 & .837 \\
\hline 10 & .755 & 56.4 & .858 \\
\hline 20 & .775 & 68.8 & .925 \\
\hline 30 & .768 & 80.0 & 1.035 \\
\hline 40 & .734 & 89.1 & 1.047 \\
\hline 450 & .680 & 95.1 & 1.011 \\
\hline 60 & .621 & 99.2 & 1.006 \\
\hline 70 & .572 & 103.7 & 1.015 \\
\hline 80 & .527 & 107.5 & 1.037 \\
\hline 90 & .478 & 108.8 & 1.044 \\
\hline 500 & .420 & 106.2 & 1.016 \\
\hline 10 & .364 & 101.7 & .982 \\
\hline 20 & .323 & 98.9 & .959 \\
\hline 30 & .299 & 99.8 & .976 \\
\hline 40 & .281 & 102.2 & 1.004 \\
\hline 550 & .264 & 103.6 & 1.017 \\
\hline 60 & .243 & 102.8 & 1.028 \\
\hline 70 & .221 & 100.3 & 1.022 \\
\hline 80 & .200 & 97.0 & 1.004 \\
\hline 90 & .182 & 93.8 & .989 \\
\hline 600 & .168 & 91.5 & .976 \\
\hline 10 & .157 & 90.7 & .980 \\
\hline 20 & .1492 & 90.5 & .997 \\
\hline 30 & .1417 & 90.3 & 1.013 \\
\hline 40 & .1344 & 89.7 & 1.027 \\
\hline 650 & .1282 & $89: 4$ & 1.045 \\
\hline 60 & .1214 & 88.3 & 1.051 \\
\hline 70 & .1135 & 85.8 & 1.052 \\
\hline 80 & .1054 & 82.6 & 1.042 \\
\hline 90 & .0963 & 78.2 & 1.011 \\
\hline 700 & .0881 & 73.8. & .983 \\
\hline 10 & .0804 & 69.4 & .957 \\
\hline 20 & .0730 & 65.0 & .922 \\
\hline
\end{tabular}

T-- Spectral Transmission of Filter at $25^{\circ} \mathrm{C}$

$V--$ Relative Visibility Function

E--Relative Energy of $2848^{\circ} \mathrm{K}$

$E^{\prime}--$ Relative Energy of Noon Sunlight at Washington June 21

$E^{\prime \prime}(=T \times E)^{*}--0000--$ Relative Energy of $2848^{\circ} \mathrm{K}$ and Filter Combination

Light Transmission of Filter

for $2848^{\circ} \mathrm{K}=0.231$

FILTER FORMULA

\section{A}

Copper Sulphate (CuSO $\left.\cdot 5 \mathrm{H}_{2} \mathrm{O}\right) \quad 2.671$ grams Mannite $\left(\mathrm{C}_{6} \mathrm{H}_{8}(\mathrm{OH})_{8}\right)$

Pyridine $\left(\mathrm{C}_{5} \mathrm{H}_{5} \mathrm{~N}\right)$

$30.0 \quad \mathrm{cc}$

Water(distilled) to make 1000 . CC

\section{B}

Cobalt Ammonium Sulphate

$\left(\mathrm{CoSO}_{4} \cdot\left(\mathrm{NH}_{4}\right)_{2} \mathrm{SO}_{4} \cdot 6 \mathrm{H}_{2} \mathrm{O}\right) \quad 19.430$ grams Copper Sulphate $\left(\mathrm{CuSO}_{4} \cdot 5 \mathrm{H}_{2} \mathrm{O}\right) \quad 21.000$ grams Sulphuric Acid (sp.gri. I.835) $10.0 \quad \mathrm{cc}$ Water (distilled) to make 1000. cc

These data are for a one centimeter layer each of solutions $A$ and $B$ in a double cell with three plates of borosilicale crown glass (refractive index. D line, $=1.51$ ), each, $2.5 \mathrm{~mm}$ thick.

" Adjusted to make sum of $E^{\prime \prime}-E^{\prime}$ from 400 to $720 \mathrm{~m} \mu$ equal practically to zero

* Factor to be used to multiply the candle-power of the light source to obtain the candle-power of the source-and-filter combination 
$2848^{\circ} \mathrm{K}$ TONOON SUNLIGHT ATWASHINGTON DEC.2I

CHART 35

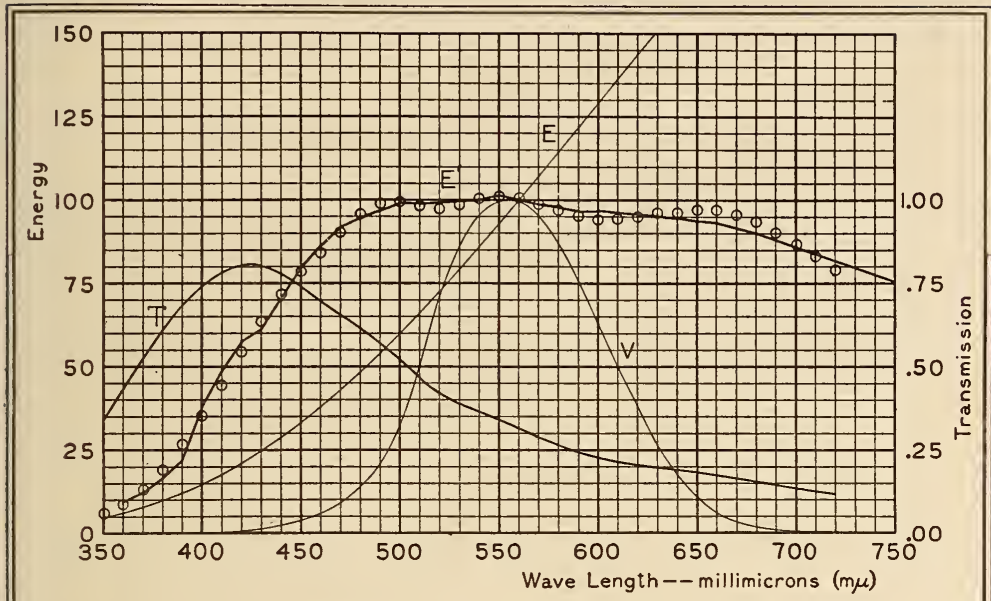

\begin{tabular}{|r|c|c|c|}
\hline$\lambda$ & $T$ & $E^{\prime \prime}$ & $E^{\prime \prime} / E^{\prime}$ \\
\hline$(m \mu)$ & $T$ & 5.1 & \\
\hline 350 & 0.334 & 1.5 & .936 \\
\hline 60 & .429 & 8.5 & 1.063 \\
\hline 70 & .523 & 13.1 & 1.14 \\
\hline 80 & .612 & 19.2 & 1.144 \\
\hline 90 & .688 & 26.7 & 1.230 \\
\hline 400 & .744 & 35.1 & .946 \\
\hline 10 & .782 & 44.4 & .910 \\
\hline 20 & .803 & 54.1 & .945 \\
\hline 30 & .801 & 63.4 & 1.040 \\
\hline 40 & .779 & 71.8 & 1.021 \\
\hline 450 & .740 & 78.6 & .988 \\
\hline 60 & .695 & 84.3 & .982 \\
\hline 70 & .656 & 90.2 & .985 \\
\hline 80 & .617 & 95.5 & 1.012 \\
\hline 90 & .572 & 98.9 & 1.021 \\
\hline 500 & .518 & 99.6 & 1.006 \\
\hline 10 & .464 & 98.3 & .996 \\
\hline 20 & .419 & 97.4 & .982 \\
\hline 30 & .388 & 98.5 & .987 \\
\hline 40 & .364 & 100.3 & 1.003 \\
\hline 550 & .340 & 101.2 & .996 \\
\hline 60 & .314 & 100.6 & 1.006 \\
\hline 70 & .288 & 98.9 & 1.003 \\
\hline 80 & .264 & 96.9 & .991 \\
\hline 90 & .244 & 95.1 & .987 \\
\hline 600 & .227 & 94.1 & .974 \\
\hline 10 & .216 & 94.4 & .983 \\
\hline 20 & .207 & 95.1 & .996 \\
\hline 30 & .198 & 95.9 & 1.008 \\
\hline 40 & .190 & 96.3 & 1.017 \\
\hline 650 & .183 & 97.0 & 1.033 \\
\hline 60 & .175 & 96.9 & 1.040 \\
\hline 70 & .166 & 95.5 & 1.045 \\
\hline 80 & .157 & 93.4 & 1.036 \\
\hline 90 & .1461 & 90.0 & 1.022 \\
\hline 700 & .1360 & 86.5 & 1.005 \\
\hline 10 & .1264 & 82.9 & .992 \\
\hline 20 & .1167 & 79.0 & .966 \\
\hline $8 u r e a u$ or 5tandards. & 0 Davis- Gibson Fiters \\
\hline
\end{tabular}

T--Spectral Transmission of Filter at $25^{\circ} \mathrm{C}$

$V$-- Relative Visibility Function

E--Relative Energy of $2848^{\circ} \mathrm{K}$

$E^{\prime}--$ Relative Energy of Noon Sunlight at Washington Dec.21

$E^{\prime \prime}(=T \times E)^{*}--0000--$ Relative Energy of $2848^{\circ} \mathrm{K}$ and Filter Combination

Light Transmission of Filter

for $2848^{\circ} \mathrm{K}=0.302$

FILTER FORMULA

A

Copper Sulphate $\left(\mathrm{CuSO}_{4} \cdot 5 \mathrm{H}_{2} \mathrm{O}\right) \quad 2.194$ grams

Mannite $\left(\mathrm{C}_{6} \mathrm{H}_{8}(\mathrm{OH})_{6}\right) \quad 2.194$ grams Pyridine $\left(\mathrm{C}_{5} \mathrm{H}_{5} \mathrm{~N}\right) \quad 30.0 \mathrm{cC}$

Water (distilled) to make 10.00. c.

\section{B}

Cobalt Ammonium Sulphate

$\left(\mathrm{CoSO}_{4} \cdot\left(\mathrm{NH}_{4}\right)_{2} \mathrm{SO}_{4} \cdot 6 \mathrm{H}_{2} \mathrm{O}\right) \quad 13.060$ grams Copper Suiphate $\left(\mathrm{CuSO}_{4} \cdot 5 \mathrm{H}_{2} \mathrm{O}\right) \quad 16.890$ grams Sulphuric Acid (sp.gr. 1.835) $10.0 \quad$ cc Water (distilled) to make 1000 . cc

These data are for a one centimeter layer each of solutions $A$ and $B$ in a double cell with three plates of borosilicate crown glass (refractive index, D line, $=1.51$ ), each $2.5 \mathrm{~mm}$ thick.

* Adjusted to make sum of $E^{\prime \prime}-E^{\prime}$ from 400 to $720 \mathrm{~m} \mu$ equal practically to zero

* Factor to be used to multiply the candle-power of the light source to obtain the candle-power of the source-and-filter combination 
ACETYLENE TO MEAN NOON SUNLIGHT AT WASHINGTON. CHART 36

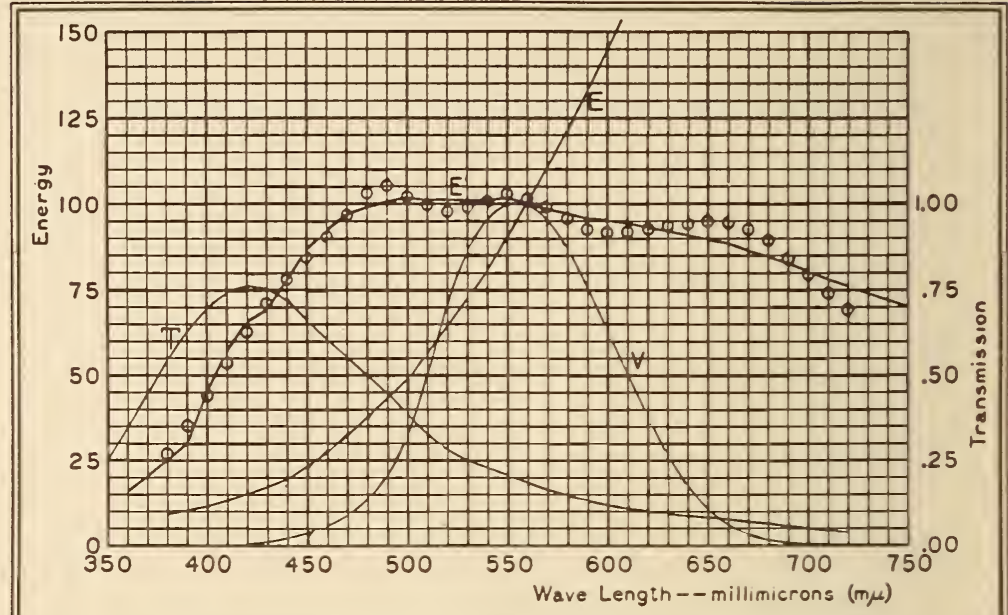

\begin{tabular}{|c|c|c|c|}
\hline$\underset{(m \mu)}{\lambda}$ & $\mathrm{T}$ & $E^{\prime \prime}$ & $E^{\prime \prime} / E^{\prime}$ \\
\hline 350 & 0.250 & $\bar{\tau}$ & \\
\hline 60 & .343 & 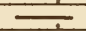 & 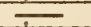 \\
\hline 70 & 442 & {[} & \\
\hline 80 & .539 & 26.8 & 1.068 \\
\hline 90 & .628 & 35.1 & 1.168 \\
\hline 400 & .692 & 44.0 & 974 \\
\hline 10 & .736 & 53.4 & .931 \\
\hline 20 & .761 & 62.9 & .955 \\
\hline 30 & .755 & 71.1 & 1.027 \\
\hline 40 & .721 & 78.0 & 1.003 \\
\hline 450 & .665 & 84.5 & .973 \\
\hline 60 & .602 & 90.4 & 980 \\
\hline 70 & .550 & 96.6 & 997 \\
\hline 80 & .501 & 103.2 & 1.042 \\
\hline 90 & .447 & 105.1 & 1.045 \\
\hline 500 & .384 & 102.2 & 1.004 \\
\hline 10 & .325 & 99.6 & .985 \\
\hline 20 & .280 & 97.8 & 966 \\
\hline 30 & .251 & 98.9 & 979 \\
\hline 40 & .229 & 100.9 & 1.000 \\
\hline 550 & .208 & 103.0 & 1.012 \\
\hline 60 & .186 & 101.4 & 1.014 \\
\hline 70 & .164 & 99.0 & 1.007 \\
\hline 80 & .1443 & 95.8 & .986 \\
\hline 90 & .1280 & 93.3 & .975 \\
\hline 600 & .1154 & 91.7 & .964 \\
\hline 10 & .1064 & 91.8 & .973 \\
\hline 20 & .0994 & 92.7 & .995 \\
\hline 30 & .0931 & 93.7 & 1.017 \\
\hline 40 & .0870 & 94.1 & 1.034 \\
\hline 650 & .0818 & 94.9 & 1.058 \\
\hline 60 & .0761 & 94.5 & 1.067 \\
\hline 70 & .0697 & 92.4 & 1.069 \\
\hline 80 & .0633 & 89.3 & 1.054 \\
\hline 90 & .0563 & 84.1 & 1.017 \\
\hline 700 & .0501 & 79.1 & .983 \\
\hline 10 & .0446 & 74.1 & .950 \\
\hline 20 & .0395 & 69.1 & .908 \\
\hline
\end{tabular}

T-- Spectral Transmission of Filter at $25^{\circ} \mathrm{C}$

$V--$ Relative Visibility Function

E--Relative Energy of Acetylene

E'-- Relative Energy of Mean Noon Sunlight at Washington

$E^{\prime \prime}(=T \times E)^{*}--0000--$ Relative Energy of Acetylene and Filter Combination

Light Transmission of Filter
for Acetylene $=0.170^{* *}$

FILTER FORMULA

A

\begin{tabular}{|c|c|c|}
\hline $\begin{array}{l}\text { Copper Sulphate }\left(\mathrm{CuSO}_{4} \cdot 5 \mathrm{H}_{2} \mathrm{O}\right) \\
\text { Mannite }\left(\mathrm{C}_{6} \mathrm{H}_{8}(\mathrm{OH})_{8}\right) \\
\text { Pyridine }\left(\mathrm{C}_{5} \mathrm{H}_{5} \mathrm{~N}\right) \\
\text { Water (distilled) to make }\end{array}$ & $\begin{array}{l}3.287 \\
3.287 \\
30.0 \\
1000\end{array}$ & $\begin{array}{l}\text { grams } \\
\text { grams } \\
\text { cc } \\
\text { cc }\end{array}$ \\
\hline \multicolumn{3}{|l|}{ B } \\
\hline $\begin{array}{l}\text { Cobalt Ammonium Sulphate } \\
\left(\mathrm{CoSO}_{4} \cdot\left(\mathrm{NH}_{4}\right)_{2} \mathrm{SO}_{4} \cdot 6 \mathrm{H}_{2} \mathrm{O}\right) \\
\text { Copper Sulphate }\left(\mathrm{CuSO}_{4} \cdot 5 \mathrm{H}_{2} \mathrm{O}\right) \\
\text { Sulphuric Acid (sp. gr. } 1.835) \\
\text { Water (distilled) to make }\end{array}$ & $\begin{array}{l}20.580 \\
26.480 \\
10.0 \\
1000 .\end{array}$ & $\begin{array}{l}\text { grams } \\
\text { grams } \\
\text { cc } \\
\text { cc }\end{array}$ \\
\hline
\end{tabular}

These dala are for a one centimeter layer each of solutions $A$ and $B$ in a double cell with three plates of borosilicate crown glass (refractive index. $D$ line. $=1.51$ ), each $2.5 \mathrm{~mm}$ thick.

* Adjusted.to make sum of $E^{\prime \prime}-E^{\prime}$ from 400 to $720 \mathrm{~m} \mu$ equal practically to zero

* Factor to be used to multiply the candle-power of the light source to obtain the candle-power of the source-and-filter combination 


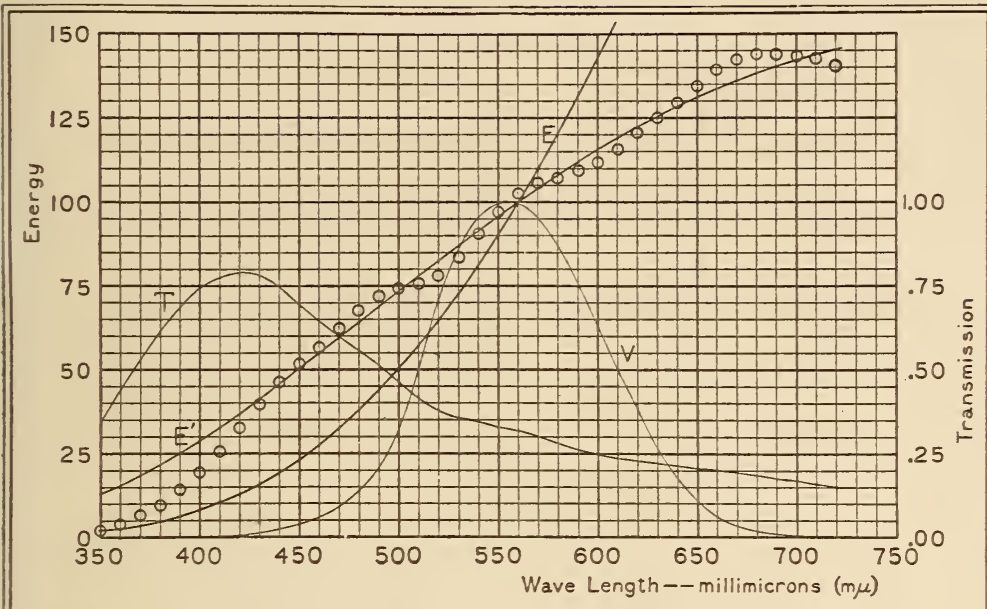

\begin{tabular}{|c|c|c|c|}
\hline $\begin{array}{c}\lambda \\
(m \mu)\end{array}$ & $T$ & $E^{\prime \prime *}$ & $E^{\prime \prime} / E^{\prime}$ \\
\hline 350 & 0.347 & 2.2 & .169 \\
\hline 60 & .441 & 3.9 & .248 \\
\hline 70 & .533 & 6.3 & $.34 i$ \\
\hline 80 & .619 & 9.7 & .448 \\
\hline 90 & .692 & 14.2 & .565 \\
\hline 400 & .743 & 19.5 & .677 \\
\hline 10 & .776 & 25.7 & .788 \\
\hline 20 & .792 & 32.7 & .892 \\
\hline 30 & .782 & 39.7 & .971 \\
\hline 40 & .749 & 46.2 & 1.020 \\
\hline 450 & .698 & 51.7 & 1.038 \\
\hline 60 & .642 & 56.5 & 1.040 \\
\hline 70 & .598 & 62.0 & 1.050 \\
\hline 80 & .557 & 67.5 & 1.059 \\
\hline 90 & .514 & 72.0 & 1.051 \\
\hline 500 & .461 & 74.1 & 1.013 \\
\hline 10 & .411 & 75.3 & .968 \\
\hline 20 & .375 & 77.9 & .945 \\
\hline 30 & .357 & 83.2 & .957 \\
\hline 40 & .347 & 90.3 & .988 \\
\hline 550 & .335 & 97.1 & 1.014 \\
\hline 60 & .319 & 102.3 & 1.023 \\
\hline 70 & .300 & 105.6 & 1.015 \\
\hline 80 & .280 & 107.7 & .997 \\
\hline 90 & .261 & 109.6 & .980 \\
\hline 600 & .246 & 111.9 & .969 \\
\hline 10 & .235 & 115.7 & .973 \\
\hline 20 & .227 & 120.4 & .986 \\
\hline 30 & .220 & 125.0 & .999 \\
\hline 40 & .214 & 129.5 & 1.010 \\
\hline 650 & .208 & 134.6 & 1.028 \\
\hline 60 & .202 & 139.1 & 1.042 \\
\hline 70 & .195 & 142.2 & 1.046 \\
\hline 80 & .187 & 143.9 & 1.042 \\
\hline 90 & 178 & $143 . \varepsilon$ & 1.027 \\
\hline 700 & 169 & 143.7 & 1.012 \\
\hline 10 & $.16 C$ & 142.6 & .993 \\
\hline 20 & .151 & 140.0 & .969 \\
\hline
\end{tabular}

$\mathrm{T}--$ Spectral Transmission of Filter at $25^{\circ} \mathrm{C}$ $V--$ Relative Visibility. Function E-- Relative Energy of $2450^{\circ} \mathrm{K}$ $E^{\prime}-$ Relative Energy of $3500^{\circ} \mathrm{K}$

$E^{\prime \prime}(=T \times E)^{*}--0000--$ Relative Energy of $2450^{\circ} \mathrm{K}$ and Filter Combination

Light Transmission of Filter
for $2450^{\circ} \mathrm{K}=0.295^{* *}$

FILTER FORMULA

A
Copper Sulphate $\left(\mathrm{CuSO}_{4} \cdot 5 \mathrm{H}_{2} \mathrm{O}\right) \quad 2.071$ grams Mannite $\left(\mathrm{C}_{6} \mathrm{H}_{8}(\mathrm{OH})_{6}\right) \quad 2.071$ grams Pyridine $\left(\mathrm{C}_{5} \mathrm{H}_{5} \mathrm{~N}\right) \quad 30.0 \mathrm{cC}$ Water (distilled) to make $1000 . \quad \mathrm{cC}$

\section{B}

Cobalt Ammonium Sulphate

$\left(\mathrm{CoSO}_{4} \cdot\left(\mathrm{NH}_{4}\right), \mathrm{SO}_{4} \cdot 6 \mathrm{H}_{2} \mathrm{O}\right) \quad 18.045$ grams Copper Sulphate $\left(\mathrm{CuSO}_{4} \cdot 5 \mathrm{H}_{2} \mathrm{O}\right) \quad 14.000$ grams Sulphuric Acid (sp.gr. 1.835) $\quad 10.0 \quad \mathrm{cc}$ Water (distilled) to make $1000 . \quad \mathrm{cc}$

These data are for a one centimeter layer each of solutions $A$ and $B$ in a double cell with three plates of borosilicate crown glass (refractive index, D line, $=1.51$ ), each, $2.5 \mathrm{~mm}$ thick.

* Adjusted to make sum of $E^{\prime \prime}-E^{\prime}$ from 400 to $720 \mathrm{~m} \mu$ equal practically to zero

* Factor to be used to multiply the candle-power of the light source to obtain the candle-power of the source-and-filter combination 
$2450^{\circ} \mathrm{K}$ To $6500^{\circ} \mathrm{K}$

CHART

38

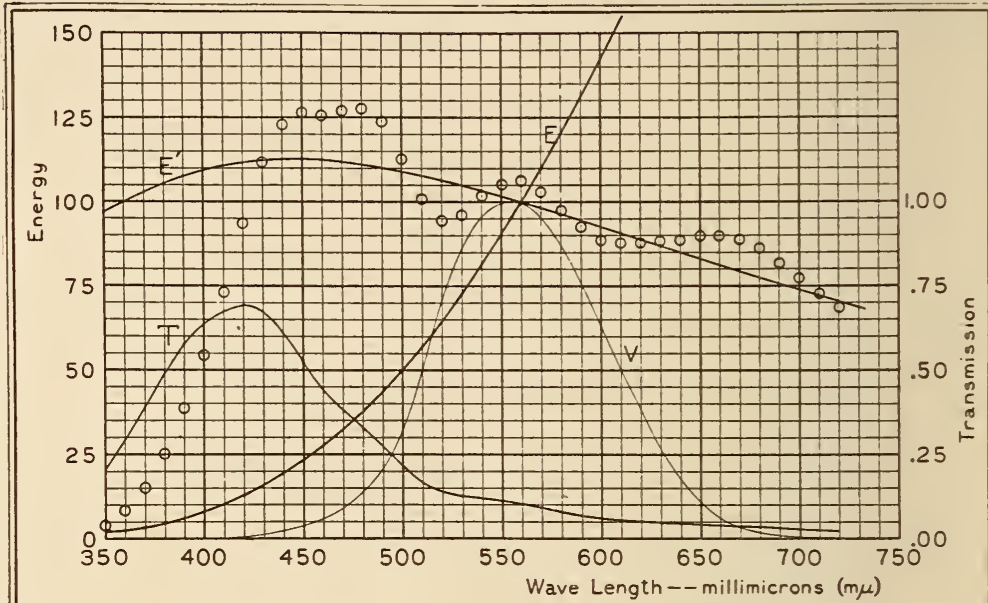

\begin{tabular}{|c|c|c|c|}
\hline$\underset{(m \mu)}{\lambda}$ & $T$ & $E^{\prime \prime *}$ & $E^{\prime \prime} / E^{\prime}$ \\
\hline 350 & 0.206 & 4.2 & .044 \\
\hline 60 & .295 & 8.4 & .084 \\
\hline 70 & .392 & 15.1 & .146 \\
\hline 80 & .489 & 25.0 & .237 \\
\hline 90 & .578 & 38.6 & .359 \\
\hline 400 & .637 & 54.4 & .497 \\
\hline 10 & .676 & 73.0 & .660 \\
\hline 20 & .695 & 93.7 & .841 \\
\hline 30 & .672 & 111.4 & .993 \\
\hline 40 & .611 & 123.0 & 1.093 \\
\hline 450 & .523 & 126.3 & 1.124 \\
\hline 60 & .437 & 125.6 & 1.119 \\
\hline 70 & .375 & 126.9 & 1.136 \\
\hline 80 & .322 & 127.3 & 1.147 \\
\hline 90 & .271 & 123.8 & 1.125 \\
\hline 500 & .215 & 1128 & 1.035 \\
\hline 10 & .169 & 100.9 & .937 \\
\hline 20 & .1395 & 94.5 & .889 \\
\hline 30 & .1264 & 96.0 & .916 \\
\hline 40 & .1196 & 101.6 & .983 \\
\hline 550 & .1122 & 106.0 & 1.043 \\
\hline 60 & .1020 & 106.5 & 1.065 \\
\hline 70 & .0898 & 103.1 & 1.050 \\
\hline 80 & .0778 & 97.7 & 1.013 \\
\hline 90 & .0675 & 92.5 & .979 \\
\hline 600 & .0598 & 88.7 & .958 \\
\hline 10 & .0546 & 87.6 & .965 \\
\hline 20 & .0508 & 8.7 .8 & .989 \\
\hline 30 & .0477 & 88.3 & 1.015 \\
\hline 40 & .0447 & 88.6 & 1.042 \\
\hline 650 & .0426 & 89.8 & 1.081 \\
\hline 60 & 0402 & 90.0 & 1.109 \\
\hline 70 & .0373 & 88.6 & 1.117 \\
\hline 80 & .0343 & 86.0 & 1.110 \\
\hline 90 & .0309 & 81.5 & 1.078 \\
\hline 700 & .0279 & 77.2 & 1.047 \\
\hline 10 & .0251 & 72.8 & 1.010 \\
\hline 20 & .0225 & 68.2 & \\
\hline
\end{tabular}

T-- Spectral Transmission of Filter at $25^{\circ} \mathrm{C}$

$V$-- Relative Visibility Function

E--Relative Energy of $2450^{\circ} \mathrm{K}$

$E^{\prime}--$ Relative Energy of $6500^{\circ} \mathrm{K}$

$E^{\prime \prime}(=T \times E)^{*}--0000--$ Relative Energy of $2450^{\circ} \mathrm{K}$ and Filter Combination

Light Transmission of Filter for $2450^{\circ} \mathrm{K}=0.0917$

\section{FILTER FORMULA}

A

Copper Sulphate $\left(\mathrm{CuSO}_{4} \cdot 5 \mathrm{H}_{2} \mathrm{O}\right) \quad 4.428 \mathrm{grams}$ Mannile $\left(\mathrm{C}_{6} \mathrm{H}_{8}(\mathrm{OH})_{6}\right) \quad 4.428$ grams Pyridine $\left(\mathrm{C}_{5} \mathrm{H}_{5} \mathrm{~N}\right) \quad 30.0 \mathrm{CC}$ Water (distilled) to make 1000 . CC

B

Cobalt Ammonium Sulphate
$\left(\mathrm{COSO}_{4} \cdot\left(\mathrm{NH}_{4}\right), \mathrm{SO}_{4} \cdot 6 \mathrm{H}_{2} \mathrm{O}\right)$ $\left(\mathrm{CoSO}_{4} \cdot\left(\mathrm{NH}_{4}\right)_{2} \mathrm{SO}_{4} \cdot 6 \mathrm{H}_{2} \mathrm{O}\right) \quad 38.930$ grams Copper Sulphate $\left(\mathrm{CuSO}_{4} \cdot 5 \mathrm{H}_{2} \mathrm{O}\right) \quad 29.000$ grams

Sulphuric Acid (sp.gr. 1.835) $10.0 \quad$ cc Water (distilled) to make $1000 . \quad$ cc

These data are for a one centimeter layer each of solutions $A$ and $B$ in a double cell with three plates of borosilicate crown glass (refractive index. D line, $=1.51$ ). each, $2.5 \mathrm{~mm}$ thick.

" Adjusted to make sum of $E^{\prime \prime}-E^{\prime}$ from 400 to $720 \mathrm{~m} \mu$ equal practically to zero

* Factor to be usec to multiply the candle-power of the light source to obtain the candle-power of the source-and-filter combination 


\section{BIBLIOGRAPHY ${ }^{21}$}

1. Ives, H. E., Color Measurement of Illuminants-A Résumé, Trans. I. E. S., 5, pp. 189-207; 1910.

2. Priest, I. G., A Precision Method for Producing Artificial Daylight,22 Phys. Rev. (2), 11, pp. 502-507; 1918.

3. Priest, I. G., Standard Artificial Sunlight for Colorimetric Purposes, ${ }^{22}$ J. Opt. Soc. Am. and Rev. Sci. Inst., 12, pp. 479-480; 1926. (For correction of printer's errors, see also J. Opt. Soc. Am. and Rev. Sci. Inst., 14, p. 70; 1927.)

4. Report of Optical Society of America Committee on Colorimetry for 192021, L. T. Troland, chairman, J. Opt. Soc. Am. and Rev. Sci. Inst., 6, pp. $527-596 ; 1922$.

5. Guild, J., A Critical Survey of Modern Developments in the Theory and Technique of Colorimetry and Allied Sciences, Proceedings of the Optical Convention, 1, pp. 61-146; 1926.

6. Report of Optical Society of America Committee on Unit of Photographic Intensity, L. A. Jones, chairman, J. Opt. Soc. Am. and Rev. Sci. Inst., 12, pp. 567-586; 1926.

7. Rapport de la Commission de 1"Optical Society of America" Sur l'Etalon Lumineux pour Sensitometrie, Proceedings, Sixth International Congress of Photography, Paris, 1925, pp. 60-70; Société Francaise de Photographie; 1926.

8. Proceedings, Sixth International Congress of Photography, Paris, 1925, pp. 23-24; Société Francaise de Photographie; 1926.

9. Frehafer, M. Katherine, and Snow, C. L., Tables and Graphs for Facilitating the Computation of Spectral Energy Distribution by Planck's formula, B. S. Misc. Pub. No. 56; 1925 (35 cents).

10. Proceedings, International Commission on Illumination, Sixth Meeting, Geneva, 1924, p. 67; Cambridge University Press; 1926.

11. Gibson, K. S., and Tyndall, E. P. T., The Visibility of Radiant Energy, B. S. Sci. Pap. No. 475; 1923 (15 cents); Trans. I. E. S., 19, pp. 176-196; 1924.

12. Gibson, K. S., The Relative Visibility Function, Proceedings, Sixth Meeting, International Commission on Illumination, pp. 232-238. (See 10, above.)

13. Ives, H. E., Artificial Daylight, J. Frank. Inst., 1\%\%, pp. 471-499; 1914.

14. Luckiesh, M., and Cady, F. E., Artificial Daylight-Its Production and Use, Trans. I. E. S., 9, pp. 839-872; 1914.

15. Brady, E. J., The Development of Daylight Glass, Trans. I. E. S., 9, pp. 937-952; 1914.

16. Gage, H. P., Daylite Glass, Sibley J. Engineering, 30, pp. 247-250; 1916.

17. Macbeth, N., Color Temperature Classification of Natural and Artificial Illuminants, Trans. I. E. S., 23, pp. 302-324; 1928.

18. Mees, C. E. K., and Sheppard, S. E., On the Sensitometry of Photographic Plates, Photo. J., 44, pp. 282-303; 1904.

19. Sheppard, S. E., and Mees, C. E. K., Investigations on the Theory of the Photographic Process, Longmans, Green \& Co.; 1907.

20. Mees, C. E. K., The Illuminating Engineer, London, 5, pp. 79-80; 1912.

21. Wratten Light Filters, 6th ed. rev., 1924, Eastman Kodak Co.

22. Naumann, H., Ein Spektrales Weisslichtfilter, Zeits. f. Wiss. Photogr., 23, pp. $303-319 ; 1924$.

23. Sinden, R. H., Studies Based on the Spectral Complementaries, J. Opt. Soc. Am. and Rev. Sci. Inst., $\boldsymbol{\gamma}$, pp. 1123-1153; 1923.

24. Guild, J., A White Light for Colorimetry, Trans. Opt. Soc., 27, pp. 122-124; $1925-26$.

25. Hilger, Adam (Ltd.), Standard Artificial Daylight, Nature, p. 13, January 14, 1928.

${ }_{21}$ National Bureau of Standards official publications may be obtained from the Superintendent of Documents, Government Printing Office, Washington, D. C., postpaid, at the prices giren.

${ }_{22}$ The values of spectral energy distribution, $E$, introduced by Priest into the work of the colorimetry section, National Bureau of Standards, some years ago, now in current use and reproduced in Figure 3 of the present paper, are not exactly the same as proposed in his earliest publication cited above. The values given here are as shown in Figure 4 of the Standards Yearbook for 1927. They are given by:

$E \propto E_{2,848} \sin ^{2} \alpha / 2$

where $E_{2,848}$ is energy per unit wave length as a function of wave length for the Planckian radiator at $2,848^{\circ}$ $\mathrm{K}$. for $\mathrm{C}_{2}$ at $14,350 \mu^{\circ}$, and $\alpha$ is the rotation of the plane of polarization of light, as a function of wave length, per $\mathrm{mm}$ in crystalline quartz. 
26. Davis, Raymond, B. S. Sci. Paper No. 409; 1921 (5 cents). Walters, Francis M., and Davis, Raymond, B. S. Sci. Paper No. 422; 1921 (15 cents). Davis, Raymond, and Walters, Francis M., B. S. Sci. Paper No. 439; 1922 (35 cents). Davis, Raymond, B. S. Sci. Paper No. 511; 1925 (15 cents). Davis, Raymond, B. S. Sci. Paper No. 528; 1926 (20 cents).

27. Coblentz, W. W., Distribution of Energy in the Spectrum of an Acetylene Flame, B. S. Sci. Paper No. 362; 1920 (5 cents).

28. Priest, I. G., Preliminary Data on the Color of Daylight at Washington, J. Opt. Soc. Am. and Rev. Sci. Inst., \%, pp. 78-79; 1923.

29. Kimball, H. H., The Distribution of Energy in the Visible Spectrum of Sunlight, Skylight, and the Total Daylight, Proc., Int. Com. on Illumination, Seventh Meeting, Saranac Inn, N. Y., 1928, pp. 501-515.

30. Priest, I. G., The Colorimetry and Photometry of Daylight and Incandescent Illuminants by the Method of Rotatory Dispersion, J. Opt. Soc. Am. and Rev. Sci. Inst., $\boldsymbol{y , ~ p p . ~ 1 1 7 5 - 1 2 0 9 ; ~} 1923$.

31. Forsythe, W. E., and Worthing, A. G., The Properties of Tungsten and the Characteristics of Tungsten Lamps, Astrophys. J., 61, pp. 146-185; 1925.

32. Hyde, E. P., Forsythe, W. E., and Cady, F. E., On the Distribution of Energy in the Visible Spectrum of an Acetylene Flame, Phys. Rev. (2), 13, pp. 379-388; 1919.

33. Ives, H. E., and Kingsbury, E. F., Experiments with Colored Absorbing Solutions for use in Heterochromatic Photometry, Trans. I. E. S., 9, pp. 795-813; 1914.

34. Ives, H. E., and Kingsbury, E. F., Additional Experiments on Colored Absorbing Solutions for use in Heterochromatic Photometry, Trans. I. E. S., 10, pp. 253-258; 1915.

35. Report of Optical Society of America Committee on Spectrophotometry for 1922-23, K. S. Gibson, chairman, J. Opt. Soc. Am. and Rev. Sci. Inst., 10, pp. $169-241 ; 1925$.

36. Peters, H. H., and Phelps, F. P., Color in the Sugar Industry, B. S. Tech. Paper No. 338; 1927 (20 cents).

37. Brode, W. R., The Spectral Absorption of Certain Monoazo Dyes, B. S. Research Paper No. 47; 1929 (15 cents).

38. Trans. I. E. S., 20, pp. 629, 632; 1925.

39. Mees, C. E. K., and Sheppard, S. E., New Investigations on Standard Light Sources, J. Roy. Photo. Soc., 50, pp. 287-292; 1910.

40. Report of Optical Society of America Committee on Unit of Photographic Intensity, L. A. Jones, chairman, Proceedings, Seventh International Congress of Photography, London, 1928, pp. 152-161; W. Heffer \& Sons (Ltd.), Cambridge; 1929.

41. Proceedings, Seventh International Congress of Photography, London, 1928, pp. $170-173$.

42. Abbot, C. G., Fowle, F. E., and Aldrich, L. B., The Distribution of Energy in the Spectra of the Sun and Stars, Smithsonian Miscellaneous Collections, r4, No. 7, Pub. No. 2714; 1923.

43. Priest, I. G., A New Study of the Leucoscope and its Application to Pyrometry, J. Opt. Soc. Am., 4, pp. 448-495; 1920.

44. Gibson, K. S., Spectral Centroid Relations for Artificial Daylight Filters, J. Opt. Soc. Am. and Rev. Sci. Inst., 11, pp. 473-478; 1925.

45. McNicholas, H. J., Equipment for Routine Spectral Transmission and Reflection Measurements, B. S. Research Paper No. 30; 1928 (20 cents).

46. Gibson, K. S., Direct-Reading Photoelectric Measurement of Spectral Transmission. J. Opt. Soc. Am. and Rev. Sci. Inst., y, pp. 693-704; 1923.

47. Gibson, K. S., Mc Nicholas, H. J., Tyndall, E. P. T., Frehafer, M. K., with the cooperation of Mathewson, W. E., The Spectral Transmissive Properties of Dyes; B. S. Sci. Paper No. 440; 1922 (15 cents).

48. McNicholas, H. J., Use of the Under-water Spark with the Hilger Sector Photometer in Ultra-violet Spectrophotometry, B. S. Research Paper No. 33; 1928 (5 cents).

49. Gibson, K. S., Spectral Characteristics of Test Solutions Used in Heterochromatic Photometry, J. Opt. Soc. Am. and Rev. Sci. Inst., 9, pp. 113$121 ; 1924$.

50. George, E. F., The Absorption of Light by Inorganic Salts, Dissertation, Ohio State University; 1920.

51. Jones, H. C. and Anderson, J. A., The Absorption Spectra of Solutions, Carnegie Institute of Washington, Pub. No. 110; 1909. 
52. Müller, E., Über die Lichtabsorption Wässeriger Lösungen von Kupfer- und Nickelsalzen, Ann. d. Phys., 12, pp. 767-786; 1903.

53. Crittenden, E. C. and Taylor, A. H., An Interlaboratory Comparison of Colored Photometric Filters, Trans. I. E. S., 24, pp. 153-207; 1929.

54. Priest, I. G. and Brickwedde, F. G., The Minimum Perceptible Colorimetric Purity as a Function of Dominant Wave Length with Sunlight as Neutral Standard, J. Opt. Soc. Am. and Rev. Sci. Inst., 13, p. 306; 1926.

55. Priest, I. G., Apparatus for the Determination of Dominant Wave Length, Purity and Brightness, J. Opt. Soc. Am. and Rev. Sci. Inst., 8, pp. 173$200 ; 1924$.

56. Calzavara, E., L'Etalon lumineux pour Sensitométrie, Observations sur la composition du filtre coloré, Science et Industries Photographiques, p. 113; November 1, 1928.

57. Skogland, J. P., Tables of Spectral Energy Distribution and Luminosity for use in Computing Light Transmissions and Relative Brightnesses from Spectrophotometric Data, B. S. Misc. Pub. No. 86; 1929 (10 cents).

58. Forsythe, W. E., Color Match and Spectral Distribution, J. Opt. Soc. Am. and Rev. Sci. Inst., 7, pp. 1115-1121; 1923.

Washington, March 21, 1930. 


